\title{
Entre a magia da voz e a artesania da letra: o sagrado em Manoel de Barros e Mia Couto
}

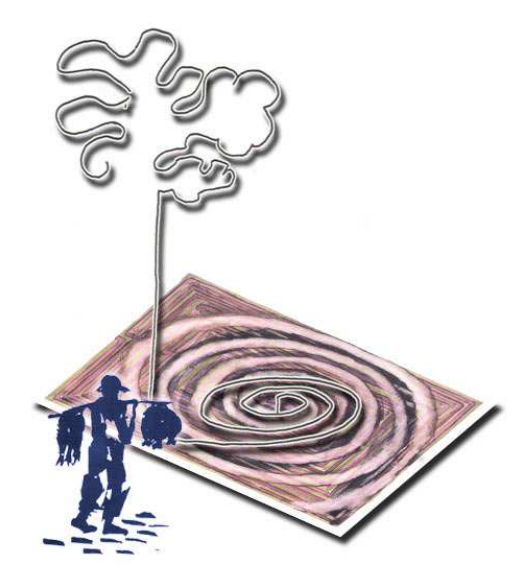




\section{Maria Auxiliadora Fontana Baseio}

\section{Entre a magia da voz e a artesania da letra: o sagrado em Manoel de Barros e Mia Couto}

Tese de Doutorado apresentada ao Departamento de Letras Clássicas e Vernáculas da Faculdade de Filosofia, Letras e Ciências Humanas da Universidade de São Paulo. Área: Estudos Comparados de Literaturas de Língua Portuguesa. Orientadora: Prof. ${ }^{a}$ Dr. ${ }^{a}$ Maria Lúcia Pimentel de Sampaio Góes.

\section{Universidade de São Paulo 2007}




\section{Maria Auxiliadora Fontana Baseio}

\section{Entre a magia da voz e a artesania da letra: \\ o sagrado em Manoel de Barros e Mia Couto}

Tese de Doutorado apresentada ao Departamento de Letras Clássicas e Vernáculas da Faculdade de Filosofia, Letras e Ciências Humanas da Universidade de São Paulo.

Área: Estudos Comparados de Literaturas de Língua Portuguesa.

Data de aprovação:

Orientadora: Prof. ${ }^{a}$ Dr. ${ }^{a}$ Maria

Lúcia Pimentel de Sampaio Góes 
Para minha filha

Heloísa 


\section{AGRADECIMENTOS}

Agradeço a todos que abriram caminho, para a plena realização desta pesquisa, em especial:

À Profa. Dra. Maria Lúcia Pimentel de Sampaio Góes - porta por-onde

À Profa. Heloísa Martins, por acenar possibilidades

À Profa. Dra. Nelly Novaes Coelho, pelo carinho com que teceu suas observações

À Profa. Dra. Maria Zilda Cunha, pelas palavras generosas e pela confiança nas horas difíceis

Ao Prof. Dr. Benjamin Abdala Junior, pelos profundos ensinamentos

À Profa. Dra. Tânia Macedo, pelas perguntas que me inquietaram

À Profa Dra. Rita Chaves, pela disponibilidade em iluminar os caminhos de África

Ao Instituto Camões pela prontidão em conceder obras referentes a Mia Couto

À minha mãe, Maria Apparecida Zanchetta - pela proteção

Ao meu marido Gerson - pela paciência

À minha sobrinha Karen Baseio, por me provocar insatisfação e curiosidade

Ao bom amigo Marcial Chaves, pelas mais lúcidas contribuições

À amiga Rita Elvira Garcia, pela generosidade

Aos amigos Peter O'Sagae e Luiz Sposito, pela amizade de todas as horas

Ao amigo Antonio Sampaio Dória, pela solidariedade

A todos os outros amigos que acompanharam de perto minha distância

À minha filha e a todas as crianças, parceiras desta "trespassagem" sagrada, que, com sua mais pura experiência, encorajaram-me a "despersianar" os olhos. 
"tudo, aliás, é a ponta de um mistério. Inclusive, os fatos.

Ou a ausência deles [...] Quando nada acontece há um milagre que não estamos vendo."

(Guimarães Rosa) 


\section{RESUMO}

Sabemos que a literatura assume contornos singulares nas franjas dos núcleos hegemônicos. Brasil e África são territórios marcados por uma profunda e complexa tensão entre elementos genuínos e elementos impostos pela colonização. Irmanar essas experiências fronteiriças é nossa tentativa neste tempo de mundialização. Esta tese analisa a dimensão do sagrado com base no estudo comparado de Manoel de Barros e Mia Couto. Compreendido como uma dimensão da existência, qualitativamente diferente da dimensão profana, embora nela manifestado, o sagrado participa do projeto estético e do projeto político dos dois autores, sendo elemento importante tanto para afirmar a identidade das duas culturas quanto para projetar um novo homem e uma nova forma de conhecimento para o século XXI. Tanto de maneira visível quanto camuflada, o sagrado compõe tanto a cultura tradicional quanto a moderna, revelando-se nas obras literárias dirigidas a adultos e a crianças. Por meio de suas fulgurações, tanto na poesia quanto na prosa, torna-se possível evidenciar raízes similares e marcas identitárias das duas culturas e das duas literaturas que compõem um macrossistema, no interior do qual nenhuma das literaturas afirma-se como paradigmática. A língua portuguesa é o instrumento com o qual Brasil e Moçambique fortalecem e irmanam suas experiências. Importa-nos, dentro do pensamento crítico, nas novas perspectivas de perceber o mundo como uma realidade de fronteiras múltiplas, buscar enlaçamentos nas sendas do comunitarismo cultural. Nosso desejo é criar laços de solidariedade passíveis de extrapolarem as fronteiras nacionais e atingirem o supranacional. Os elementos transcendentes com que o leitor entra em contato pela via do imaginário fertilizam sua experiência vivida, potencializando transformações no porvir. Acreditamos ser a literatura terreno fértil da cultura, chão de criar e de projetar o homem, instrumento catalisador da conscientização e da transformação humana.

Palavras-chave: Mia Couto, Manoel de Barros, sagrado, identidade, comunitarismo 


\section{ABSTRACT}

Literature assumes singular contours in the surround of the hegemonic countries. Brazil and Africa are territories marked by complex tension between genuine elements and elements imposed by colonization. Our attempt is to bring together these bordering experiences in this thesis of Comparative Literature in which we reflect on the sacred elements as a significant source to help build identity. We present a comparative reading of Mia Couto and Manuel de Barros, as examples of Brazilian and African culture. The sacred, seen as a dimension of existence, different from the profane component (although present in it), is part of the aesthetic and political project of both authors, being important to establish the identity of these cultures, as well as to project a new human being and a new way of knowing and learning in the XXI century. Either visible or disguised, the sacred is part of both the traditional and the modern culture, being present in works of literature for adults or children. Through its manifestation, both in poetry and prose, it is possible to spot similar roots and identity features in the two cultures and literatures that compose a macrosystem, in which none of them can be considered a paradigm. Portuguese language is the means with which Brazil and Mozambique strengthen and unite their experiences. It is our aim, in our critical thinking, to find, in the new ways of experiencing multiple border realities, a tangling of communities and their cultures. We would like to create bonds of solidarity capable of expanding across national borders as to reach the 'supranational'. The transcendent elements shown to the reader in the imaginary path nurture his actual living experience, making for possible changes in the future. We believe literature to be the ground on which culture thrives, empowering the human being, triggering understanding and transformation.

Key-words: Mia Couto, Manoel de Barros, sacred, identity, comunitarism 


\section{RESUMEN}

Sabemos que la literatura asume contornos singulares en las fajas de los núcleos hegemónicos. Brasil y África son territorios marcados por una profunda y compleja tensión entre elementos originales y elementos impuestos por la colonización. Hermanar esas experiencias fronterizas es nuestra tentativa, en estos tiempos de mundialización. Esta tesis analiza la dimensión de lo sagrado con base en el estudio comparativo de Manoel de Barros e Mia Couto. Comprendido como una dimensión de la existencia, cualitativamente diferente de la dimensión profana, aunque en ella se manifieste, lo sagrado participa del proyecto estético y del proyecto político de los dos autores, siendo un elemento importante tanto para afirmar la identidad de las dos culturas como para proyectar un nuevo hombre y una nueva forma de conocimiento para el siglo XXI. Tanto de manera visible como camuflada, lo sagrado compone tanto la cultura tradicional como la moderna, revelándose en las obras literarias dirigidas a los adultos y a los niños. Por medio de sus fulguraciones, tanto en la poesía como en la prosa, es posible evidenciar raíces semejantes y las marcas de identidad de las dos culturas y de las dos literaturas que componen un macrosistema, en el interior del cual ninguna de las literaturas se afirma como paradigmática. La lengua portuguesa es el instrumento con el cual Brasil y Mozambique fortalecen e hermanan sus experiencias. Nos interesa, dentro del pensamiento crítico, en las nuevas perspectivas de percibir el mundo como una realidad de fronteras múltiplas, buscar los enlaces en las sendas de la comunidad cultural. Nuestro deseo es criar lazos de solidariedad pasibles de extrapolar las fronteras nacionales y alcanzar lo supranacional. Los elementos transcendentes con los que el lector entra en contacto por la vía del imaginario fecundan su experiencia vivida, otorgando potencialidad para transformaciones en el porvenir. Creemos que la literatura sea un terreno fértil de la cultura, tierra de criar y de proyectar el hombre, instrumento catalizador de la conciencia y de la transformación humana.

Palabras-Ilave: Mia Couto, Manoel de Barros, sagrado, identidad, comunitarismo 


\section{OBSERVAÇÕES}

Optamos pelo uso da expressão 'estória' ao nos referirmos às narrativas ficcionais. Segundo indicação de nossa orientadora, Lúcia Pimentel Góes, fundamentando-se em teóricos da competência da Prof. Dra. Nilce Sant'Anna Martins - que afirma não se tratar de anglicanismo o termo 'story', com o sentido de estória narrada ou ficcional - e em outros, como o saudoso Prof. Dr. Bóris Schnaidermann, um dos maiores tradutores da língua russa, que utiliza, nas traduções das obras de Mikhail Bakhtin, o termo 'estória'. O termo também foi grafado assim por Guimarães Rosa e por Mia Couto.

A palavra 'história' foi utilizada, nesta tese, como referência à passagem temporal. Com maiúscula, 'História' refere-se tanto à área do conhecimento científico como à História da Humanidade, em sentido genérico.

Quanto aos autores citados no corpo do trabalho, preferimos utilizar nomes e sobrenomes para evitar qualquer equívoco.

Optamos por colocar em recuo as citações bibliográficas menores de três linhas no capítulo referente a Manoel de Barros - Capítulo 4 -, por julgar conveniente para a leitura, uma vez que se trata de poesia. Mantivemos no corpo do texto apenas citações de um verso ou pequenos fragmentos. 


\section{SUMÁRIO}

APRESENTAÇÃo .

INTRODUÇÃO

1 ANDANÇAS PELO REINO DO SAGRADO

1.1 A busca de um sinal .

2 NAS CERCANIAS DA ANTROPOLOGIA $\quad$ - $\quad$. $\quad$. $\quad$. 34

2.1. O CONCEITO DE SAGRADO E DE PROFANO . . . . $\quad 35$

2.1.1 A cosmogonia como arquétipo da criação . . 41

2. 1.1.1 0 fazer literário como ato sagrado $\quad$. $\quad$. 43

2.1.1. 2 A 'performance' ou a leitura como atos sagrados $\quad 46$

2. 2. A CAMUFLAGEM DO SAGRADO $\quad$. $\quad$. $\quad$. $\quad$. 49

2.3. A DIALÉTICA DO SAGRADO E DO PROFANO. . . 54

2.4. O SIMBOLISMO DO SAGRADO . . . . . . . 55

3 NAS FRONTEIRAS DA LITERATURA COMPARADA . . 60

3.1 Entre nós e os outros $\quad$. $\quad . \quad$. $\quad . \quad$. $\quad . \quad$. $\quad$. 61

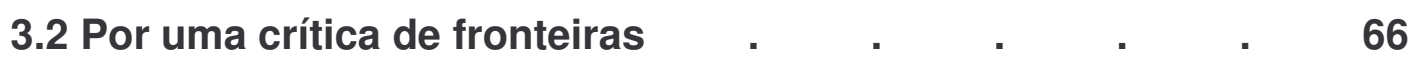

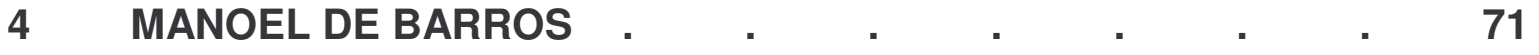

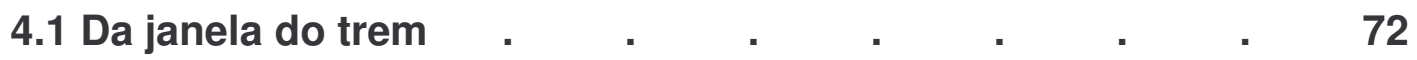

4.1.1 Simbologia das origens . $\quad$. $\quad$. $\quad$. $\quad$. 118

4.2 Um pouco mais de poesia para amanhecer . . . $\quad$. 119

4.3 Poeminhas pescados numa fala de João . . . . 137

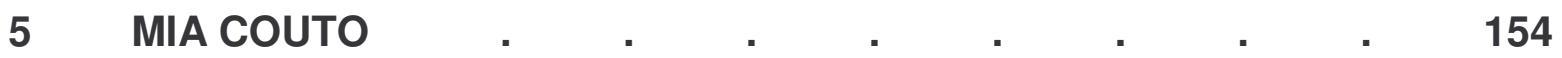

5.1 No balanço do barco: em busca da ilha . . . . . 155

5.1.1 A simbologia da terra $\quad$. $\quad$. $\quad$. $\quad$. $\quad$. 188

5.1.2 A simbologia da água $\quad . \quad$. $\quad$. $\quad$. $\quad$. $\quad$. 192

5.1.3 A ilha como síntese $\quad . \quad$. $\quad . \quad$. $\quad . \quad . \quad . \quad 196$ 
5.2 A magia da voz para transcender . $\quad$. $\quad$. $\quad$. $\quad$. 198

5.30 Gato e o Escuro . . . . . . . . . . 206

6 SAGRADO EM MANOEL DE BARROS E MIA COUTO . 225

6.1 De Inícios e fronteiras . . . . . . . . . . 226

6.2 Para "despersianar" os olhos . . . . . . . 239

6.3 Os filhos da estrada/ Na zona fronteiriça $\quad$. $\quad$. $\quad$. 249

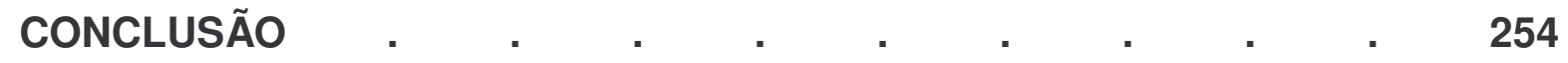

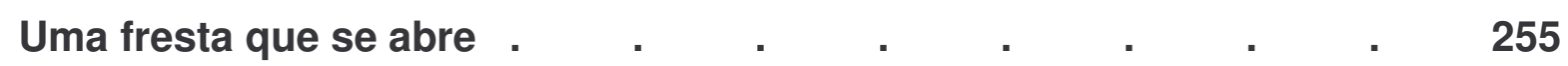

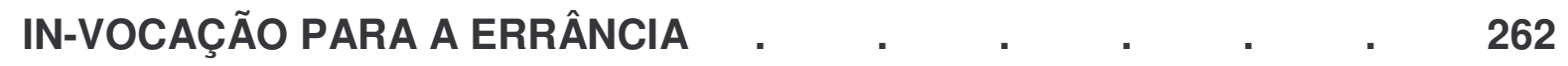

O método como uma incerta viagem . $\quad . \quad$. $\quad . \quad$. $\quad$. 263

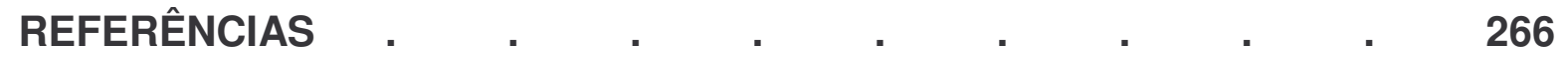

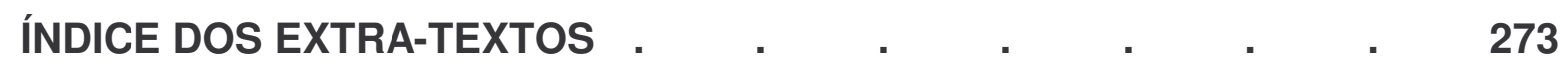

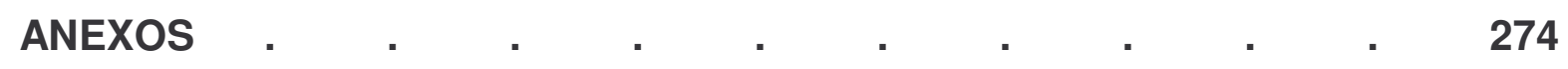




\section{APRESENTAÇÃO}

A própria vida é um tecido

(às vezes um tecido mágico, de proporções cósmicas).

(Mircea Eliade)

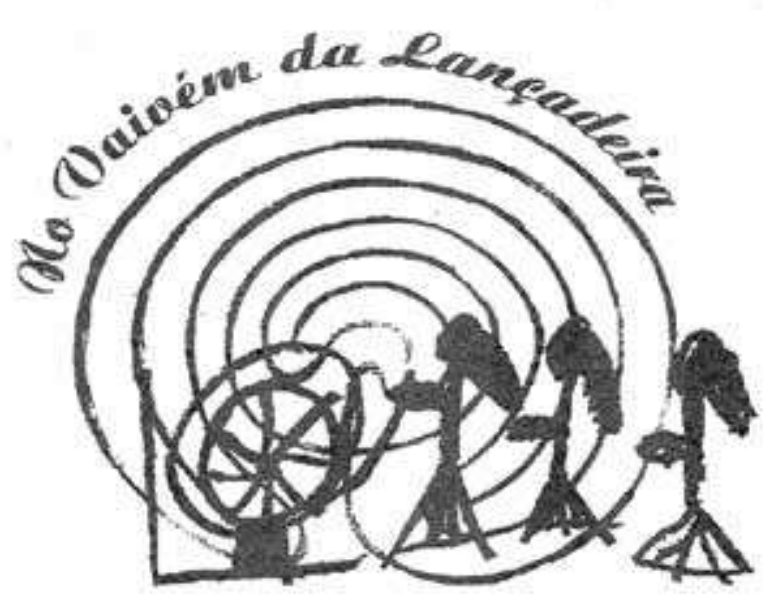

O retorno do Sagrado na

va literatura infantil / juvenil

de Língua Portuguesa 
Não há conhecimento sem sujeito, nem narração sem ser versão. Por isso, hoje, é esta a estória a ser contada.

Certa vez, ao satisfazer o desejo de minha sobrinha de três anos, que me pedida para contar estórias, narrei, na qualidade de tia boazinha, Chapeuzinho Vermelho, em uma versão à minha moda, na qual não aparecia o lobo mau. Julgava aquela cena do lobo comendo a vovó e a menina de uma violência absurda. Ao terminar a narrativa, a menina, de olhar frustrado, mas ainda um tanto paciente comigo, reclamou: "Tia, agora conta de novo, porque você contou tudo errado. Você esqueceu do lobo que come a vovó e a Chapeuzinho! Conta de novo! Conta de novo!"

Mesmo sem compreender a fundo, naquele momento, a solicitação de minha sobrinha, resolvi contar a estória novamente, mas na versão tradicional, segundo a qual a menina e a vovó são devoradas pelo lobo. Foi assim que aquela criança se mostrou satisfeita e eu, insatisfeita, com uma infinidade de indagações, nunca mais parei de pesquisar o assunto.

Comecei a buscar informações, fazer leituras sem-fim, até poder, em 1990, elaborar um projeto de pesquisa para a disciplina de Metodologia da Pesquisa Científica, na área de Antropologia da USP, como trabalho final de graduação em Ciências Sociais. Tamanho foi meu empenho que, além da nota máxima na disciplina e, sob o conselho da professora Heloísa Martins, o projeto foi levado para - Mestrado em Estudos Comparados em Literaturas de Língua Portuguesa na mesma instituição. E quando menos percebi, aquela preocupação privada acabou por tornar-se pública - podendo, assim, contribuir para novas pesquisas e novas descobertas.

Rememorar essa passagem da minha vida leva-me, diretamente, a uma frase de Rainer Maria Rilke ${ }^{1}$, recomendando a Krappus que procure

[...] amar as próprias perguntas como quartos fechados ou livros escritos num idioma muito estrangeiro. Não busque por enquanto respostas que não lhe podem ser dadas, porque não as poderia viver. Pois trata-se precisamente de viver tudo. Viva por enquanto as perguntas. Talvez depois, aos poucos, sem que o perceba, num dia longínquo, consiga viver a resposta.

\footnotetext{
${ }^{1}$ RILKE, R. M. Cartas a um jovem poeta. Trad. Paulo Rónai. Rio de Janeiro, Globo, 1995. p. 42.
} 
Em 1997, acolhida pela admirada professora de Literatura Infantil Lúcia Pimentel Góes, ingressei no Mestrado. Foram noites e dias lendo e refletindo sobre o mundo onírico, fadas, bruxas, príncipes, princesas, animais, mitos, símbolos, arquétipos enfim elementos que compõem o Imaginário ${ }^{2}$ - substrato capaz de reunir homens, mulheres, adultos, crianças, negros, brancos, índios, culturas tradicionais, culturas modernas e pós-modernas, em um mesmo aposento, irmanados por tudo que há de mais universal. Nesse aposento, configurado como uma espécie de entrelugar, foi possível ler os sinais do sagrado.

Minha Dissertação de Mestrado, defendida em 2000, teve como título No vaivém da lançadeira: o retorno do sagrado na literatura infantil/juvenil de Língua Portuguesa. Ali tentei alinhavar meus conhecimentos em Antropologia com minhas descobertas em Literatura para crianças e jovens. Assim, pude responder, publicamente, o que se colocava, há tanto tempo, para mim, como indagação, contribuindo, dessa forma, para despertar novas perguntas para tantos outros.

Os escritos do Mestrado, sempre embalados pelos ventos das intermináveis madrugadas e pelo ócio das férias, versavam sobre o sagrado nos contos de fadas. Auxiliada por Mircea Eliade, autor conhecido no curso de Antropologia Religiosa e, nesse momento, estudado com afinco, compreendi o sagrado como um modo de ser a compor, ao lado do profano, duas situações existenciais assumidas pelo homem ao longo de sua história. Enquanto o profano diz respeito ao mundo cotidiano, da mesmice, da vida ordinária, o sagrado apresenta-se como algo extra-ordinário. 0 sagrado toca algo profundo e essencial do homem, ultrapassando, portanto, 0 conhecimento positivo, sendo uma categoria da sensibilidade, para além da razão.

Foram inúmeras as leituras feitas até chegar a esse conceito, tais como Émile Durkheim, Mauss, Lévy-Bruhl, Lévi-Strauss, Vitor Turner Roger Caillois, Roger Bastide, René Girard, Rudolf Otto, entre outros.

Cheguei à conclusão de que o sagrado e o profano são necessários ao desenvolvimento da vida. O profano é o meio concreto, material, físico no qual se desencadeia a vida cotidiana e o sagrado é de ordem qualitativamente diferente,

\footnotetext{
${ }^{2}$ Imaginário é função e produto da imaginação. Definido a partir de diferentes óticas, o conceito tem sido tema de profundos estudos e debates. Adotamos, neste trabalho, a concepção de Gilbert Durand, que entende o imaginário como o "conjunto das imagens e das relações de imagens que constitui o capital pensado do homo sapiens".(DURAND, Gilbert. As Estruturas Antropológicas do Imaginário. Trad. Hélder Godinho. São Paulo, Martins Fontes, 1997. p. 14).
} 
manifestando-se como fonte inesgotável capaz de criar, manter e renovar a vida ordinária.

Descobri um laço fecundo entre essa idéia de sagrado, antropologicamente concebido - vale ressaltar não ter sido estabelecido vínculo com nenhuma instituição religiosa -, e o imaginário que nutre a literatura para crianças e jovens.

Julguei, portanto, ser de grande importância rastrear as Imagens Sagradas presentes nessa literatura para a juventude, em especial os contos de fada - esse foi meu recorte -, uma vez que essas imagens possibilitam uma relação mais humanizadora com o leitor.

Selecionei, como narrativa-guia, A Bela Adormecida. Essa escolha também teve um componente subjetivo. Ela me acompanhou por 180 noites (faltou muito para 1.001 noites), nas quais minha filha solicitava ouvir a mesma estória. Depois de tantas vivências - porque quem conta vive - já não era mais eu que narrava, mas a estória se narrava por mim. Então, não tive dúvida - ou saída - analisei a Bela Adormecida e algumas de suas variações, com o intuito de mostrar, nas releituras do conto, a perpetuação de algumas Imagens Sagradas, formadoras de uma espécie de Herança Imemorial que possuímos.

Analisei cinco diferentes versões, colhidas por escritores e estudiosos em meio ao povo de diversas regiões, línguas e épocas. Iniciei com a versão do napolitano Giambattista Basile (1575-1632), "Sole, Lune e Talia”, apresentada no Pentameron ou $O$ conto dos contos. Em seguida, comparei com a versão do francês Charles Perrault (1628-1703), que adaptou a narrativa ao gosto da corte, onde florescia uma verdadeira moda do conto. Depois, cotejei com a mais difundida versão incluída na coletânea publicada pelos Irmãos Grimm, (Jacob,1785-1863; Wilhelm,1786-1859), ambos filólogos e eruditos alemães, cujo objetivo de perenizar a vasta produção poética popular oriunda da Idade Média, arriscada a esvanecer-se por ser apenas oral, levou-os a recolher mais de duzentas estórias entre os camponeses de seu país. Subseqüentemente, adentrei a cultura portuguesa, com uma variante de Teófilo Braga, publicada, pela primeira vez, em 1885 - "A saia de esquilhas" - e, por fim, explorei a terra brasileira, com seus costumes, tradições e linguajar tão característicos nas versões de Câmara Cascudo, "A princesa do sonosem-fim" e de Silvio Romero, "O rei caçador". Após toda essa andança por diferentes espaços e tempos, finalmente alcancei o século XXI, mostrando as configurações assumidas pelas imagens sagradas nas narrativas modernas conhecidas por 'Objeto 
Novo'3. Para isso, analisei Cibermãe, de Alexandre Jardin, na qual a Bela Adormecida repousa em um sarcófago eletrônico, dentro de um 'site', em uma torre digital.

Concluí que, entre a criação artesanal e os múltiplos fios que tecem as sinuosas malhas virtuais, a Literatura para crianças e jovens assume uma urdidura renovada, entretanto traz meadas muito antigas. Em última instância, pude descobrir ser possível enxergar um 'Objeto Novo' engendrando o antigo. Além disso, pude perceber permanecerem do antigo, justamente, as imagens sagradas, capazes de perpassar o tempo e atravessar as diferentes culturas. Essas são as imagens passíveis de abrir a possibilidade de se re-encantar o mundo, a vida e as relações humanas, e a literatura para crianças e jovens guarda esse tesouro quase como um segredo.

Após esse profundo e espesso diálogo entre teoria e prática, entre vida pensada e vida vivida, pude compreender o que se passou com minha sobrinha naquela ocasião na qual solicitava a presença do lobo em Chapeuzinho Vermelho. Eu havia suprimido da estória exatamente as imagens mais sagradas: o retorno ao ventre, cuja função simbólica é marcar o rito de iniciação da personagem. Essa passagem, revelada exatamente na cena mais dramática do conto, abriga, de fato, uma importante simbologia - a simbologia do Centro. Segundo Mircea Eliade ${ }^{4}$, o Simbolismo do Centro revela sempre um lugar sagrado onde todas as forças se unem para promover a passagem de um modo de ser a outro, ou seja, para se realizar um ritual de iniciação. Essa simbologia tem relação direta com o arquétipo da iniciação, que pressupõe descida ao inferno e ascensão ao céu, ou, por outras palavras, uma ruptura de nível. O ritual iniciático manifesta-se pelo simbolismo do 'regressus ad uterum'. É como se o útero fosse o centro dentro do qual a iniciação ocorre. Regressar ao útero é repetir a gestação, é morrer, simbolicamente, para o passado, podendo nascer de novo de maneira diferente - uma transformação existencial universal que prepara uma passagem de ordem mística e espiritual.

De acordo com Eliade ${ }^{5}$ :

\footnotetext{
3 Objeto Novo: denominação de Lúcia Pimentel Góes para os livros que apresentam uma Concentração de Linguagens de natureza vária e variada, extrapolando o Invólucro Físico Tradicional.(GÓES, Lúcia P. Olhar de Descoberta. São Paulo, Mercuryo,1996).

${ }^{4}$ ELIADE, Mircea. Mito do eterno retorno. Trad. José Antônio Ceschin. São Paulo, Mercuryo,1992.

${ }^{5}$ Idem, ibidem. p. 27.
} 
[...] o Centro é o âmbito do sagrado, a zona da realidade absoluta. [...]. A estrada que leva ao centro é um 'caminho difícil' (durohana), [...] A estrada é árdua, repleta de perigos, porque, na verdade, representa um ritual de passagem do âmbito profano para o sagrado, do efêmero e ilusório para a realidade e a eternidade, da morte para a vida, do homem para a divindade. Chegar ao centro equivale a uma consagração, uma iniciação; a existência profana e ilusória de ontem dá lugar a uma nova, a uma vida que é real, duradoura, eficiente.

Para o referido autor, todo ser humano tende para o Centro - área que lhe confere a sacralidade, a realidade integral. A iniciação, para ele, não é exclusiva das sociedades tradicionais, ela coexiste com a condição humana. Por isso, nossa existência é constituída por uma série ininterrupta de provas, mortes e renascimentos.

Como suprimir da narrativa o momento mais simbólico, de maior revelação e de maior significado para a existência humana? Retirar a cena do retorno ao ventre era retirar a possibilidade de ser. Minha sobrinha intuía isso aos três anos - só eu não percebi.

Depois dessa descoberta, fiquei enfeitiçada e nunca mais consegui parar de estudar o sagrado. Confesso ter vivido "trespassagens" das mais espessas nessa trajetória, entretanto nunca desisti do percurso e continuo a ter profundas revelações dessa instância vital nas minhas andanças pela Literatura, agora em outra dimensão diferente daquela dos contos de fadas. Ousei, novamente, singrar mares e, desta vez, na travessia de Brasil à África, nas ondas do Imaginário, encontrei o Outro e com ele pude descobrir a mim mesma, e a minha cultura. Ouvi o canto do Outro e nele o rumor de minha voz. Testemunhei veredas políticas e me deleitei com a paisagem estética. Entre lampejos de percepção do particular e do universal, do efêmero e do eterno, aportei, definitivamente, no reino das palavras em permanente infância, em ritmo encantado de jogo. Ali, pude auscultar os sons inusitados das origens, o sussurrar de sonhos e desejos intensos. Consagrei viagem de aventura. Assim, no exercício da travessia, fui des-aprendendo, entrevendo-me pequena, na horizontalidade das imagens, na verticalidade das letras, nas espessuras dos distintos contextos, até encontrar-me no ponto em que a vida se torna pleno horizonte. Fiquei em estado de "criançamento", virei para sempre 'ser em busca', 'Homo-viator', andarilho. Como ascendi à criança, agora sou capaz de afivelar o 
tempo, ousar caminhos, brincar com o estabelecido, enamorar-me do desnecessário, fazer peraltagens de voz e letra. E agora, já nem tenho mais medo de que o dia envelheça, porque encontrei, nas profundezas do ínfimo, um abridor de amanhecer. Com ele, posso, todas as manhãs, desler os atos de vileza e me vadiar pelas coisas rasteiras e profundas, capazes de me pôr imensa no chão do dia e me sobressaltar todas as noites em viagem.

No balanço de meu corpo, na travessia de dias e noites, de sinal em sinal, tenho prosseguido meu percurso até o ponto inexistente de chegada, melhor dizer, o ponto de limiar para novos percursos, novos itinerários, novas "trespassagens". Quem me ensinou tudo isso? "Com quem desaprendi a vida ordinária? Primeiramente com as crianças, depois com Manuel de Barros e Mia Couto. Com o calmo sussurrar de suas vozes, "despersianei” meus olhos, aprendi a pescar sentido no insignificante, decidi "transver" a vida e o mundo. Foi assim que alarguei as idéias, "botei enchimento" nas palavras, e me lancei em permanente travessia. Ambos acenderam horizonte nas minhas estreitas linhas fronteiriças.

Meu maior sonho, hoje, é me alimentar desse deslumbramento e dar abertura a minha a voz para que nunca a escura profundeza da vida se mostre por completo para mim - (devo confessar ter seu des-cobrimento me acontecido bem mansamente), pois é essa curiosidade infinita, em forma de lacuna e de infância, a força motivadora de meu sentido de viver. E se essa profundeza não se mostra inteira - aleluia! É a referência do muito que falta até o dia de seu pleno descortinamento, ou do cobrimento final.

$E$ foi assim... O que era vidro se quebrou. $E$ o que era papel molhou-se. Entrou por uma porta, saiu pela outra, o rei meu senhor que lhe conte outra... 


\section{INTRODUÇÃO}

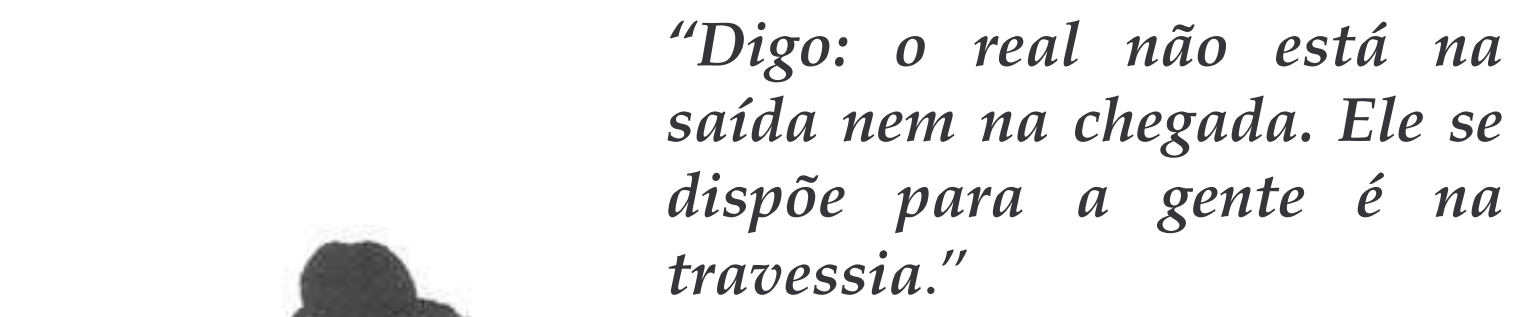

saída nem na chegada. Ele se dispõe para a gente é na travessia."

(Guimarães Rosa)

Ilustração 1 - arte de Jorapimo para o livro Poemas concebidos sem pecados de Manoel de Barros (1987) 
Sabemos que a literatura assume contornos singulares nas franjas dos núcleos hegemônicos. Brasil e África são territórios marcados por uma profunda e complexa tensão entre elementos genuínos e elementos impostos pela colonização. Irmanar essas experiências fronteiriças é nossa tentativa neste tempo de mundialização. É sob a luz da literatura comparada que desfilarão nossas reflexões sobre a linguagem, o ser humano e a história. Nosso pensar incide sobre as fulgurações do sagrado como fontes significativas capazes de fortalecer as raízes identitárias, tanto da cultura brasileira quanto da cultura africana.

Como objeto de indagação de pesquisadores de diversas áreas, o sagrado tem sido permanentemente estudado. Entretanto é no seio da Antropologia Religiosa que ele ganha força. Por ser esta uma área do conhecimento que estuda o homem, e a dos Estudos Comparados de Literatura vergar-se para as articulações entre as culturas humanas, torna-se possível estabelecer fluxos e diálogos entre as duas searas, na tentativa de fazer avançar o conhecimento, que em tempos de globalização, não mais se sustenta por fronteiras fixas.

Ao rastrearmos os diversos autores que tratam desse tema, encontramos em Mircea Eliade, em especial, pistas que permitem orientar nossas andanças pelos domínios literários.

Compreendendo o sagrado e o profano como duas modalidades de ser no mundo; definindo e diferenciando o homem religioso do homem a-religioso, dentro de uma perspectiva que enxerga, predominantemente, o homem ocidental moderno como a-religioso e o homem das comunidades arcaicas ou tradicionais como religiosos; considerando a permanência da religiosidade nas várias situações existenciais modernas; apresentando a origem da literatura como sagrada, o autor nos acena com a possibilidade de concretizarmos e fundamentarmos, de maneira coerente, nossa pesquisa.

Além da noção de sagrado, recortamos três núcleos conceituais para servirem de guia à nossa pesquisa: camuflagem; dialética do sagrado e do profano e simbologias. Nem todos esses conceitos serão permanentemente conclamados no decurso destas páginas, pois funcionam como pressupostos ou premissas a partir das quais encaminharemos nossas análises.

Apenas a título de introduzir o assunto de maneira simplificada, a camuflagem é entendida como a forma escondida de retorno do sagrado no mundo moderno, dada a necessidade humana do transcendente. A dialética do sagrado e do profano 
consiste na exigência de o sagrado manifestar-se no profano. As simbologias remetem a imagens cifradas que revelam o mistério da vida humana, como uma experiência afetiva. Identificá-las ou vivenciá-las significa abrir canais para a construção de uma solidariedade humana universal. Como sementes, as cifras simbólicas são capazes de potencializar transformações. Todos esses conceitos poderão ser melhor compreendidos nos capítulos a eles destinados.

Além de Mircea Eliade, contamos com outros autores, a serem convocados a participar de nossa discussão quando se fizer necessário.

Nossa proposta, intuitiva inicialmente, é de que pelas fulgurações do sagrado, atualizado em imagens simbólicas, seremos capazes de irmanar as duas culturas brasileira e africana - em suas singulares manifestações estéticas.

Essa experiência investigativa abrirá a possibilidade de nos espelharmos no outro e de percebermos semelhanças e diferenças. Nessa relação, seremos capazes de indagar sobre nosso modo de estar no mundo, sobre nossas memórias, sobre nossos sonhos, enfim, sobre a forma como conduzimos nossa aventura existencial do ponto de vista da cultura em que nos inserimos.

Essas percepções advirão dos territórios literários dentro dos quais realizaremos nossa travessia, a princípio separadamente, a fim de perscrutar a especificidade dos autores, das obras, das culturas, alinhavando elementos históricos e estéticos. Priorizaremos dois tipos de leitura analítica: uma horizontal, na qual vislumbraremos, no conjunto da obra, a cosmovisão do autor manifestada em seu projeto político e estético; uma vertical, em que nos aprofundaremos na espessura de um texto. Os textos escolhidos para o corte vertical são endereçados a crianças e jovens. Essa opção deve-se à possibilidade que a literatura para a juventude nos oferece para explorar os elementos sagrados, não apenas na linguagem verbal, mas, também, na visual. As obras analisadas são: Poeminhas pescados numa fala de João, do brasileiro Manoel de Barros e O gato e o escuro, do moçambicano Mia Couto.

Após a análise horizontal do conjunto da obra de cada autor, acompanhada de sua leitura vertical, procederemos à comparação das duas literaturas, quanto aos projetos políticos e aos estéticos dos autores, apontando elementos de aproximação e de distanciamento.

Como realidades próprias, as obras de Manoel de Barros e as de Mia Couto exprimem, cada qual, uma visão de homem, uma posição diante de certos temas por 
meio dos quais se torna possível compreender "o espírito e a sociedade", relembrando Antonio Candido ${ }^{6}$.

Este consagrado pesquisador nos auxiliará na fundamentação do estudo comparativo das literaturas dos países de língua oficial portuguesa que pretendemos abraçar. Sua noção de sistema literário permitiu a Benjamin Abdala Junior ${ }^{7}$ assinalar o conceito de macrossistema, ao engendrar um território mais vasto, supranacional, no interior do qual nenhuma das literaturas - no caso, nem a brasileira nem a africana - cabe afirmar-se como paradigmática.

Como representantes desses sistemas literários que compõem 0 macrossistema, estão Manoel de Barros e Mia Couto.

A escolha de Manoel de Barros justifica-se pela constatação de uma presença contínua de elementos sagrados em sua poesia e pela maneira singular com que os aborda, sem comprometer-se com dogmas, credos ou verdades absolutas, motivando-se, muito mais, por um imaginário aberto a múltiplas ligações do homem com o transcendente. Em sua poesia, nota-se a forma como o discurso do circunstancial transcende a imanência e contempla o indizível, religando o leitor ao transcendente pelas ressonâncias da origem da linguagem e do homem.

Mia Couto foi escolhido por reconhecermos, em seus textos, um olhar religioso sobre o mundo e sobre a vida, por nos acenar com marcas sagradas de uma religiosidade característica das sociedades tradicionais, por compreendermos a importância de sua obra na construção da identidade moçambicana e por revelar, em semelhança com Manoel de Barros, uma consciência mágica, grávida de maravilhoso, capaz de encantar o leitor e fazer "milagrar" a vida humana.

Brasil e África foram os universos escolhidos pela força de ligação de suas culturas, ou seja, pelos laços históricos e afetivos que os unem. Esses países compartilham uma ecologia cultural similar: são territórios mestiços, marcados pela pluralidade cultural, pela tensão entre elementos autóctones e elementos impostos pela colonização.

\footnotetext{
${ }^{6}$ CANDIDO, Antonio. Formação da literatura brasileira. 8.ed., Belo Horizonte, Itatiaia, 1997. v.1. p.34.

7 ABDALA JR. Benjamin. De vôos e ilhas: literaturas e comunitarismos. São Paulo, Ateliê editorial, 2003. p. 103.
} 
A língua portuguesa é o instrumento com o qual Brasil e Moçambique fortalecem e irmanam suas experiências, abrindo possibilidades às duas culturas compósitas $^{8}$ de caminharem, lado a lado, na preciosa aventura humana.

Importa-nos, dentro do pensamento crítico, nas novas perspectivas de perceber o mundo como uma realidade de fronteiras múltiplas, buscar enlaçamentos nas sendas do comunitarismo cultural. Nesse projeto, interessa-nos, sobremaneira, os países de língua portuguesa. Nosso desejo é criar laços de solidariedade, passíveis de extrapolarem as fronteiras nacionais e atingirem o supranacional.

Esse exercício investigativo pretende assumir-se andarilho, na medida em que não pretende fechar-se em territórios fixos, nem se compor como resposta definitiva, ao contrário, busca fazer travessias, na forma de viagens: ora de trem, ora de barco, procurando ler as aparições do sagrado nas zonas fronteiriças, fazendo de cada descoberta um entrelugar.

${ }^{8}$ Expressão cunhada por Eduard Glissant e permite orientar as reflexões atuais sobre povos colonizadores e povos colonizados. As culturas compósitas, também chamadas de crioulas, são compostas de elementos heterogêneos e abertas ao contato com outras culturas, sempre dispostas a mesclar. Veiculam-se na oralidade, por meio de causos, contos, mitos e lendas. Diferentemente, as culturas atávicas, formadas há muito tempo, filiam-se a um território e procuram se expandir, além de sobrepor-se àquelas com que se deparam em seu percurso histórico. Veiculam-se por meio da escrita, de textos impressos. (GLISSANT apud ABDALA JR., Benjamin. Fronteiras múltiplas, identidades plurais. São Paulo, Senac, 2002. p.16-17.). 


\section{CAPÍTULO 1}

\section{ANDANÇAS PELO REINO DO SAGRADO}

"Chaminé que construísse em minha casa não seria para sair o fumo, mas para entrar o céu."

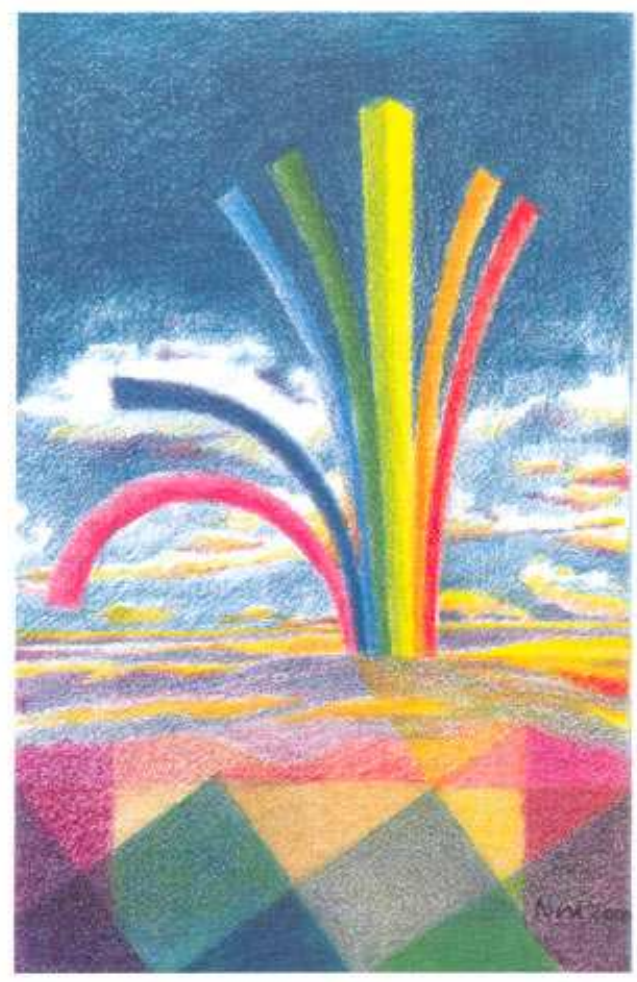

(Dito do avô Celestiano em Mia Couto)

Ilustração 2 - arte de João Nazi Pereira para Mar me quer, de Mia Couto (2000) 


\subsection{A busca de um sinal}

Há tempo, o sagrado, como tema, vem inquietando pensadores, cientistas sociais, pessoas em geral, levando-os a apresentar até mesmo algumas reservas, ora sobre o caráter metafísico da questão, ora a não universalidade da oposição sagrado/profano, estabelecida pela maioria dos pesquisadores, pois há sociedades, em especial as tradicionais, em que toda a realidade estaria imersa no sagrado, não estando este separado do profano.

É no seio da Antropologia Religiosa que o tema encontra ressonância. O sagrado vem sendo considerado como uma realidade antropológica, ou seja, como algo especificamente humano, porque todas as sociedades parecem ter desenvolvido esse tipo de noção.

Ao estudar os aspectos do símbolo na linguagem, nas artes, na cultura, esse ramo da Antropologia centraliza suas reflexões sobre o homem, construtor de símbolos, na sua relação com aquilo que considera o sagrado, especialmente nas religiões de micro-sociedades. Por estudar o homem, esse campo da Antropologia pode fertilizar outros domínios do conhecimento - isso nos possibilita aproximá-lo da Literatura e, com ela, entrelaçá-lo em uma tentativa de romper fronteiras fixas.

Muitos foram os autores que refletiram sobre esse tema, desde Platão até os mais contemporâneos, como Tylor, M. Muller, Frazer, Mauss, Lévy-Bruhl, M. Griaule, M. Leenhardt, Lévi-Strauss, V. Turner, Émile Durkheim, Rudolf Otto, Mircea Eliade, Roger Caillois, Roger Bastide, René Girard, entre tantos outros.

Fazer toda a trajetória de Platão aos contemporâneos seria por demais exaustivo e, ao mesmo tempo, um esforço desprovido de sentido para nosso propósito. Nossa intenção é apresentar um breve cenário teórico para compor uma visão horizontal do tema e, logo depois, verticalizá-la, ao mergulhar na espessura dos pilares teóricos que nos favorecerão uma nova leitura da literatura brasileira e africana, tanto dirigida para adulto, quanto dirigida para a juventude.

Para tanto, apontaremos concepções de alguns desses autores, com os quais estabelecemos diálogo no estudo do tema desta pesquisa.

Émile Durkheim ${ }^{9}$, sociólogo nascido na cidade de Épinal, em 1858, escreveu uma obra de referência sobre a questão do sagrado, As formas elementares da vida

\footnotetext{
${ }^{9}$ DURKEHIM, E. As formas elementares da vida religiosa. São Paulo, Paulinas, 1989. p. 68.
} 
religiosa, na qual o distingue como traço essencial dos fenômenos religiosos e define-o como oposto ao profano.

Todas as crenças religiosas conhecidas, sejam elas simples ou complexas, apresentam um mesmo caráter comum: supõem uma classificação das coisas, reais ou ideais, que os homens representam em duas classes ou dois gêneros opostos, designados geralmente por dois termos distintos, traduzidos relativamente bem pelas palavras profano e sagrado. A divisão do mundo em dois domínios, compreendendo um, tudo que é sagrado, outro tudo que é profano, tal é o traço distintivo do pensamento religioso; as crenças, os mitos, os gnomos, as lendas são representações ou sistemas de representações que exprimem a natureza das coisas sagradas, as virtudes e os poderes que thes são atribuídos, sua história, suas relações entre si e com as coisas profanas.

São sagrados, para esse autor, não apenas deuses, mas também pedras, árvores, casas, ritos, palavras e assim por diante. Para ele, os fatos religiosos trazem elementos a partir dos quais nascem as várias manifestações da vida coletiva, tais como a ciência, a arte, o direito, entre outras.

A essência do religioso, para o autor, está nas suas formas elementares, pois crenças e ritos são marcados pelas idéias de 'mana', 'totem' e 'tabu'. Essa foi a maneira por ele utilizada para ordenar as representações coletivas apresentadas nas religiões primitivas. $O$ 'mana' designa um poder impessoal e sobrenatural que suscita espanto, terror ou admiração, uma força anônima e difusa, princípio vital presente nos homens e nos 'totens', produto da sociedade e nela tem algo de sagrado. $O$ 'totem' designa categorias de espécies vegetais e animais usados para dar nome a um clã, uma espécie de princípio de pertença ao grupo. Como emblema, representado em postes, armas, corpos, remete ao antepassado mítico do grupo, estando na origem das proibições alimentares, sexuais e outras. Já o 'tabu' refere-se a um interdito sacralizado, a qualidade do que é atingido pela proibição, porque é consagrado ou impuro. Transgredi-lo ocasiona mácula. Sua função é proteger o valor de bens, de seres, submetendo o indivíduo à lei do grupo.

Para o referido autor, coisas e seres sagrados protegeriam o indivíduo e a comunidade das interdições, enquanto seres e coisas profanas seriam elementos submetidos às interdições, e só teriam relação com os primeiros pelos ritos estabelecidos pela crença que sustenta essa divisão do mundo. 
O sagrado, na visão durkheimiana, seria um anseio de potência, de uma energia atuando sobre o profano. O sentimento do sagrado teria origem na própria vida social, ou seja, o que o homem religioso adoraria, por meio de sua religião, seria a própria sociedade, seus valores, sua visão de mundo. Assim, remeteria para o campo do sagrado tudo aquilo considerado importante para a reprodução social. Desse modo, para ele, o sentimento e as atitudes para com o sagrado não se aplicariam apenas aos objetos religiosos, mas também a qualquer outra esfera da vida social, a exemplo da esfera cívica, familiar, amorosa ou política.

As idéias de Émile Durkheim tiveram grande influência nos diversos estudiosos de seu tempo e para além dele.

Marcel Mauss ${ }^{10}$ defende a idéia de que a religião é da ordem da realidade simbólica. Em "Ensaio sobre a dádiva", mostra, ainda, implicitamente, existir íntima ligação entre o simbolismo e a dádiva, a obrigação de dar, receber e retribuir. Aquilo que Émile Durkheim acreditava poder explicar pela religião, Marcel Mauss explica pelo simbolismo. Para tanto, deixa de ser necessário recorrer à dicotomia entre o sagrado e o profano para tomar lugar a oposição entre simbólico e utilitário.

René Girard ${ }^{11}$, em $A$ violência e o sagrado centra suas discussões naquilo que compreende ser os eventos primeiros do processo civilizatório. Mostrando o papel da violência fundadora, considera o sagrado como algo sacrificial em grande medida, pois é a morte real ou simbólica que sacraliza a vítima emissária, distanciando-a do mundo cotidiano.

É comum aos diversos pesquisadores pensar a noção de sagrado atrelada à noção de rito. Embora existam ritos profanos, por exemplo, boas maneiras à mesa, o termo rito associa-se ao domínio do religioso e define-se, segundo Claude Riviére ${ }^{12}$, como "um conjunto de actos repetitivos e codificados, por vezes solenes, de ordem verbal, gestual ou de postura, com forte carga simbólica, fundados sobre a crença na força actuante dos seres ou de poderes sagrados, com os quais o homem tenta comunicar, visando obter um determinado efeito".

\footnotetext{
${ }^{10}$ MAUSS, Marcel. Sociologia e Antropologia. Trad. Paulo Neves. 2.ed., São Paulo: Cosac Naify, 2005.

${ }^{11}$ GIRARD, René. A violência e o sagrado. Trad. Martha Conceição Gambini. 2.ed., São Paulo, Paz e Terra, 1990.

${ }^{12}$ RIVIERE, Claude. Introdução à Antropologia. Lisboa, Perspectiva/ Edições 70, 2002. p.154.
} 
Roger Callois ${ }^{13}$ parte das descobertas da escola durkheimiana e das pesquisas de Marcel Mauss, confronta-as com as dos mestres da sociologia alemã, inglesa e americana e, em sua obra O Homem e o Sagrado, inaugura uma nova sociologia francesa. Se para Durkheim, o sagrado era visto como uma força ('mana'), para Callois, ele é visto apenas em suas características. Apresenta o conceito de sagrado como o universo das energias, das forças opostas ao profano mundo das substâncias e das coisas. O sagrado toca algo profundo e essencial no homem, ultrapassando, portanto, o conhecimento positivo, sendo uma categoria da sensibilidade, não da razão.

Para o referido autor, sagrado e profano são necessários ao desenvolvimento da vida. O profano é o meio concreto, material, físico no qual se desencadeia a vida cotidiana e o sagrado é de uma ordem diferente, manifestando-se como fonte inesgotável que a cria, mantém e renova. Em sua forma elementar, o sagrado representa "uma energia perigosa, incompreensível, arduamente manejável, eminentemente eficaz"14.

Ele apresenta dois aspectos sociais importantes do sagrado: o sagrado de respeito - que mantém a integridade social - e o sagrado de transgressão - que renova, recusa o envelhecimento da sociedade e se manifesta por meio da festa.

Ao lado dessas teorias sociológicas do sagrado, aparecem outras, as fenomenológicas, para as quais o contexto histórico é menos importante do que a essência das manifestações. É como representante desta linha teórica que se insere Rudolf Otto, teólogo, historiador das religiões, filósofo alemão, nascido em 1869, em sua obra $O$ Sagrado, publicada em 1917, em que apresenta uma análise de fundamento kantiano sobre a essência irracional da religião, compreendida como o numinoso, e sua relação com o racional. O autor compreende o sagrado como uma categoria que denota a manifestação do 'numen', em latim, que significa deidade, poder divino, como o "outro absoluto", algo totalmente distinto de qualquer outra experiência. Sua tese revela a noção do sagrado como algo divino, diferente da realidade natural perceptível e distante dos processos de racionalização.

O autor enfatiza a idéia da irracionalidade que compõe o sagrado. O irracional para ele é algo singular, não passível de explicação conceitual, parte de uma

\footnotetext{
${ }^{13}$ CALLOIS, Roger. O Homem e o Sagrado. Trad.Geminiano Cascais Franco. Lisboa, Perspectivas do Homem/Edições 70, 1988.

${ }^{14}$ Idem, ibidem. p. 22.
} 
obscura profundidade. A presença do numinoso culmina com um estado de alma que se "abre às impressões do Universo, a elas se abandona e nelas mergulha". ${ }^{15}$ Essa reação emocional e intuitiva, experimentada diante do objeto numinoso, é chamada de estado de criatura, uma percepção da pura existência, um sentimento de ínfima criatura diante do grande mistério do sagrado.

Descrevendo as características desse fenômeno, o autor revela a experiência do 'mysterium tremendum et fascinans'. 'Mysterium' é a forma; 'tremendum' é o conteúdo repulsivo que provoca terror; 'fascinans' exerce fascinação. Portanto, o sagrado é misterioso, inefável, inatingível, uma força fascinante e temível.

O estudo de Rudolf Otto compreende o sagrado como categoria 'a priori', ou seja, é uma fonte de conhecimento profunda que existe originalmente na alma, é uma faculdade da alma, um impulso interno, uma predisposição para o conhecimento por meio dos sentimentos. Não podendo localizar a origem desse sentimento, define-o como 'a priori', mas não inato. Enfatiza, também, que analogamente, o mistério se assemelha ao sublime, elemento da estética, similar ao numinoso, por trazer em sua essência algo de misterioso, repulsivo e atrativo. Exemplifica essa analogia da seguinte maneira: a letra de uma música é o elemento racional e os componentes sonoros os não racionais, que se relacionam e esquematizam os sentimentos desencadeadores de emoções que servem de expressão do numinoso. Assim, o numinoso exprime-se na arte por meio do sublime, que faz vibrar a alma, cria a impressão mágica, o encanto capaz de aproximar da verdade pelo silêncio, pela obscuridade, pela penumbra.

Esse sentimento do mágico é uma forma abrandada do numinoso, e da mesma maneira é capaz de velar e de revelar o conhecimento do sublime, do eterno, do indiferenciado. Assim, conclui-se que o sublime e o mágico da arte são meios indiretos, atenuados, diluídos de expressão do numinoso. Este só pode ser vivenciado pelo espírito quando despertado por situações sagradas que alteram o estado de alma, em uma espécie de epifania, de revelação interna. Desta forma, o sentimento numinoso ganha, nos estudos desse autor, o estatuto ontológico. A essência numinosa porta uma ambigüidade fascinante e tremenda.

Mircea Eliade, nascido na Romênia em 1907, historiador das religiões, filósofo, poeta, romancista, escreveu várias obras importantes que revelam suas

${ }^{15}$ OTTO, Rudolf. O Sagrado. Lisboa, Perspectivas do Homem/Edições 70, s.d. p.188. 
permanentes indagações sobre o sagrado. Em seus escritos, o referido autor, ora retoma conceitos enunciados por alguns dos autores aqui apresentados, ora os critica. Ele se posiciona contrariamente à idéia de Émile Durkheim que reduz o religioso a fato social e concorda com a visão durkheimiana de que o sagrado se manifesta como uma força, mas discorda da teoria do 'mana' como força universal e impessoal.

Quanto às idéias de Rudolf Otto, Mircea Eliade reconhece que são de grande valor. Dele retém a noção do sagrado como o totalmente outro, de ordem distinta do natural. Entretanto, propõe outra perspectiva. A ele não interessa o que o sagrado comporta de racional ou de irracional, apresenta o sagrado em sua totalidade. Para ele, o sagrado é forte e poderoso justamente por ser real, por conferir sentido. Assim como para a maioria dos teóricos, para Mircea Eliade o sagrado e o profano designam duas modalidades de ser no mundo. Entretanto, para ele, o sagrado manifesta-se.

A manifestação do sagrado provoca essa diferenciação do mundo e é por meio dela que o mundo surge, pois essa realidade participa do ser e sua manifestação funda ontologicamente o mundo.

Ao tratar dos mitos, revela que foi por meio de um ato sagrado de uma entidade sobrenatural que tudo passou a ser e é devido a essa irrupção do sagrado que o mundo foi criado e se tornou o que é hoje.

Para ele e para muitos estudiosos das sociedades ditas primitivas, no mito, compreendido como narrativa fundadora enunciada em linguagem metafórica, tornase possível perceber a relação do homem com o sagrado. Contada em fragmentos, a narrativa mítica circula de geração a geração, pode ser considerada como a raiz das fábulas, das lendas, portanto da própria literatura.

Para indicar o ato da manifestação do sagrado, Mircea Eliade utiliza o conceito de hierofania. Trata-se da manifestação de algo de ordem qualitativamente diferente da realidade cotidiana. Ao manifestar-se, o sagrado revela as modalidades do ser e da divindade, caracterizadas por classes de hierofanias (aparições do sagrado): uraniana (celeste), aquática, vegetal ou antropomórfica. Ao manifestar-se, o sagrado historiciza-se, ou seja, exprime-se de acordo com as características socioculturais, históricas da sociedade na qual se manifesta. O seu pensamento aborda a experiência religiosa por meio de uma compreensão do divino como imanente - e essa é outra grande contribuição desse autor, um avanço em relação 
às abordagens anteriores. Essa imanência explicita-se pelo conceito de dialética do sagrado e do profano.

Esse conceito, combinado ao simbolismo que o compõe, mostra a originalidade da abordagem desse autor, abrindo-nos a possibilidade de transitar para outras áreas do conhecimento que igualmente se voltam para o Homem, como a Literatura.

O sagrado, para Mircea Eliade, manifesta-se como hierofania, por meio de qualquer objeto, lugar, ser do mundo profano. Entretanto, essa realidade profana apenas revela o transcendente na medida em que é iluminada pelo símbolo. Esse estudo da lógica dos símbolos - cerne da hermenêutica desse pesquisador - aponta para a racionalidade em que se insere o fenômeno religioso - abordagem que difere bastante das interpretações positivistas, materialistas, empiristas e historicistas, que, muitas vezes, circunscrevem o sagrado ao âmbito da subjetividade.

Fazendo frente ao pensamento iluminista, o historiador das religiões estuda as situações vividas pelo homem religioso, a fim de desvelar significações essenciais para a vida do homem contemporâneo.

Para o referido autor, com cuja hermenêutica entramos em consonância, em nosso intuito de analisar a literatura brasileira e africana, o homem religioso - 'homo religiosus' - assume um modo de existência reconhecível: crê que existe sempre uma realidade absoluta que transcende este mundo, mas nele se manifesta e, por isso, santifica-o, tornando-o real; crê que a vida tem origem sagrada e que a existência humana a atualiza. Em contrapartida, o homem a-religioso recusa a transcendência, aceita a relatividade da realidade e, muitas vezes, até duvida do sentido da existência. Ressalva o autor que, nas sociedades européias modernas, o homem a-religioso desenvolveu-se plenamente, embora possa ter existido em culturas arcaicas. Entretanto, o homem religioso é característico das sociedades primitivas e das civilizações arcaicas, que, na visão dele, já foram ultrapassadas pela História, mas acabaram por deixar seus traços.

Pretendemos nos beneficiar do conceito de sagrado proposto por esse autor e recortado da Antropologia para fundamentar nossa leitura da Literatura Brasileira e Africana, estabelecendo elementos de aproximação e de distanciamento entre esses dois universos. Entretanto, cumpre ressaltar que nossa análise comparativa se valerá do aparato teórico proposto pela Literatura Comparada, acreditando ser essa postura metodológica saudável para uma compreensão mais profunda das duas 
culturas, uma vez que as matrizes teóricas importadas de uma área do conhecimento afim, a Antropologia, não podem responder a contento à proposta de leitura de uma obra literária, que igualmente possui suas ferramentas teóricas.

Nos capítulos seguintes, enfocaremos os referenciais teóricos mencionados com mais detalhamento. Primeiramente, aprofundaremos conceitos relevantes da matriz antropológica de Mircea Eliade e, em seguida, abordaremos conceitos importantes da Literatura Comparada. 


\section{CAPÍTULO 2}

\section{NAS CERCANIAS DA ANTROPOLOGIA}

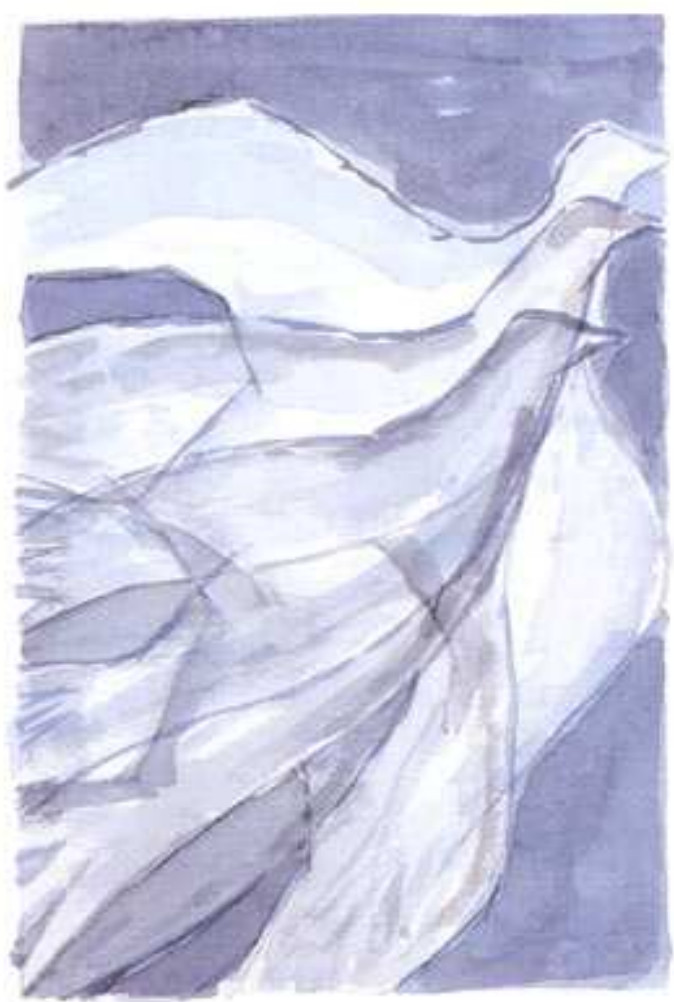

Ilustração 3 - arte de João Nazi Pereira para Estórias Abensonhadas, de Mia Couto (2000)
O grande caminho não tem portas. Milhares de caminhos levam a ele. Quando atravessamos esse umbral sem porta, caminhamos livremente entre o céu e a terra.

(Mumon - sábio Zen)

"Descobri que todos os caminhos levam à ignorância." (Mia Couto) 


\subsection{O Conceito de Sagrado e de Profano}

Neste capítulo, pretendemos aprofundar o conceito de sagrado, tal como será compreendido no contexto deste trabalho.

O sagrado é uma das maneiras do 'insere in mundo', é fonte de sentido, sem o qual o homem seria incapaz de se construir como 'homo significans'. Por isso, de alguma maneira, ele busca aproximar-se do sagrado, como se experimentasse uma sede de sentido e de ser. Em concordância com Mircea Eliade ${ }^{16}$, entendemos o sagrado como um fenômeno complexo que, ao lado do profano, compõe outra modalidade de ser no mundo. Conforme o referido autor: "o leitor não tardará a darse conta de que o sagrado e o profano constituem duas modalidades de ser no mundo, duas situações existenciais assumidas pelo homem ao longo da sua história"17.

O homem só pode conhecer o sagrado porque ele se manifesta em hierofania, apresentando-se diferente do profano. Ao manifestar o sagrado, um objeto passa a ser outra coisa e, ao mesmo tempo, ela mesma. Uma árvore sagrada não deixa de ser árvore. Entretanto, ao se revelar sagrada, essa árvore transmuta-se em sobrenatural. Assim, tudo o que pertence ao Cosmos pode manifestar o sagrado, portanto pode constituir-se em hierofania.

O sagrado remete ao que está saturado de ser, de realidade, de perenidade, de eficácia, fonte de vida e de fecundidade.

Mircea Eliade ${ }^{18}$ afirma que o homem das sociedades tradicionais - 'o homo religiosus' - vive em um Cosmos sacralizado, enquanto o homem das sociedades modernas vive em um Cosmos dessacralizado, entretanto mantém o vínculo com o sagrado de maneira camuflada. Por isso, não é possível dizer que o sagrado esteja presente apenas no estágio primitivo do desenvolvimento da consciência humana tal como postulava o positivismo ${ }^{19}$.

${ }^{16}$ ELIADE, Mircea. O sagrado e o profano: a essência das religiões. Trad. Rogério Fernandes. Lisboa, Edição Livros do Brasil.s.d.

${ }^{17}$ Idem, Ibidem. p. 28.

${ }^{18}$ Idem, Ibidem. p. 211

${ }^{19}$ Auguste Comte estabelece a lei dos três estágios: o teológico, o metafísico e o positivo. O sagrado seria elemento significativo nos dois primeiros estágios, os quais deveriam ser superados pelo terceiro, ou seja, no estágio positivo, a ciência alcançaria toda sua força e sobrepujaria os elementos patológicos da humanidade, entre os quais se inclui o sagrado.(COMTE, Auguste. Os Pensadores. 2.ed., São Paulo: Abril Cultural, 1983). 
Importante observar que o sagrado manifesta-se no espaço e no tempo. Mircea Eliade ${ }^{20}$ apresenta o espaço sagrado como qualitativamente distinto do profano: "todo espaço sagrado implica uma hierofania, uma irrupção do sagrado que tem por resultado destacar um território do meio cósmico envolvente e torná-lo qualitativamente diferente".

O espaço sagrado é um espaço significativo, com forma, consistência, marcado por um ponto fixo norteador, considerado centro. Por isso, ele é real. Manifesta uma realidade absoluta, capaz de fundar ontologicamente o mundo, portanto ele não é homogêneo, já que aponta quebras, rupturas, aberturas pelas quais se faz a comunicação do Céu à Terra, da Terra ao mundo inferior e vice-versa. A experiência do espaço sagrado possibilita a fundação do mundo, projeta-se um ponto fixo, um Centro no caos e ali se estabelece uma ruptura de nível, ou seja, abre-se um canal de comunicação entre os níveis cósmicos -Terra, Céu -, tornando possível o trânsito de um nível ontológico a outro. Revela uma experiência da nãohomogeneidade, que é primordial e homóloga à criação do mundo. Essa revelação do espaço sagrado tem, portanto, uma valência existencial. Ensina Mircea Eliade ${ }^{21}$ : "para viver no mundo é preciso fundá-lo - e nenhum mundo pode nascer no caos da homogeneidade e da relatividade do espaço profano". No espaço sagrado, revela-se uma realidade outra, distinta da ordinária.

O espaço profano traduz-se como amorfo, neutro, homogêneo, nele nada é passível de diferenciação qualitativa, nada há de absoluto, ele é sempre relativo, os pontos centrais não possuem estatuto ontológico único, eles aparecem e desaparecem. Constitui-se esse espaço como uma série de fragmentos relativamente neutros pelos quais o homem transita coagido por suas obrigações.

É justamente desse espaço ordinário que Manoel de Barros e Mia Couto retiram o leitor ao arremessá-lo no espaço extra-ordinário de suas obras, em que a natureza é a marca.

Manoel de Barros funda um mundo no território imaginário do Pantanal, faz da natureza sua casa e seu santuário. Esse é o espaço sagrado escolhido pelo autor para imitar a criação exemplar dos deuses, a cosmogonia.

\footnotetext{
${ }^{20}$ ELIADE, M. O sagrado e o profano: a essência das religiões. Lisboa, Edição Livros do Brasil, s.d. p.40.

${ }^{21}$ Idem, ibidem. p.36.
} 
No livro de pré-coisas, na parte 1 - Ponto de partida - o poema em prosa "Anúncio" apresenta:

Este não é um livro sobre o Pantanal. Seria antes uma anunciação. Enunciados como que contrastivos. Manchas. Nódoas de imagens. Festejos de linguagem. Aqui o organismo do poeta adoece a Natureza. De repente um homem derruba folhas. Sapo nu tem voz de arauto. Algumas ruínas enfrutam. Passam louros crepúsculos por dentro dos caramujos. E há pregos primaveris.

(Atribuir natureza vegetal aos pregos para que eles brotem nas primaveras...Isso é fazer natureza. Transfazer.)

Essas pré-coisas de poesia ${ }^{22}$.

O poeta anuncia transformar - "transfazer" - o caos, o que é pré-coisa, em cosmos, em matéria de poesia. O espaço anunciado pelo poeta compõe-se de elementos da natureza arranjados de maneira original, no sentido de único e de primeiro. "Ruínas que enfrutam", "pregos primaveris" são construções inusitadas; ao mesmo tempo, sugerem inícios, com o verbo "enfrutar", como engravidar, e "primaveris", remetendo a algo que floresce brota, portanto inicia um processo. Esses elementos, retirados do universo natural - enfrutar-fruta; primaveris-primavera - compõem a anunciação, momento do discurso primeiro. Não é apenas a natureza que se apresenta em seu aspecto caótico primordial, mas também a linguagem, ao dobrar sobre si mesma, em forma de "manchas", "nódoas de imagens", "festejos de linguagem".

Assim, Manoel de Barros anuncia não só esse poema, mas toda a sua obra que se constitui como um exercício de desconstrução para novo construir.

A obra do escritor brasileiro forma-se como um verdadeiro cosmos, tecido por imagens do mundo celeste e superior, como andorinhas, sabiás, pombas, estrelas, borboletas; do mundo terrestre, como formigas, onças, tartarugas; do mundo inferior, tais como serpentes, lesmas, rãs, lagartos, vermes que pululam. Todos os elementos se organizam de forma a ressacralizar a natureza, esta que se configura como um 'habitat' santificado, porque se constitui como 'imago mundi', homóloga ao Cosmos. No espaço natural é que se consagra o Centro do Mundo do poeta

\footnotetext{
${ }^{22}$ BARROS, Manoel. Livro de Pré-coisas. 4.ed., Rio de Janeiro, Record, 2003. p.9.
} 
brasileiro, por meio do qual estabelece comunicação com o transcendente. Ele reinventa a experiência primeira do espaço sagrado.

O grande eixo estruturador desse mundo criado é a árvore, como se nota em: "as árvores me começam" 23 , ou "eu queria aprender o idioma das árvores." 24 A árvore compõe-se como eixo do mundo - 'axis mundi' - eixo com base nos quais se sustenta o mundo criado pelo autor.

Mia Couto, assim como Manoel de Barros, plasmam seu espaço imaginário, predominantemente, na natureza. Em $O$ gato e o escuro, Mia Couto ${ }^{25}$ atualiza as imagens naturais do sol e da lua. Além disso, nota-se a ruptura, característica do espaço sagrado, pela travessia que Pintalgato ousa fazer do dia para a noite, passagem de uma região cósmica a uma outra, do mundo da luz-dia para o mundo das trevas-noite: "[...] certa vez, inspirou coragem e passou uma perna para o lado de lá, onde a noite se enrosca a dormir. [...] Fechou os olhos e andou assim, sobrancelhado, noite adentro. Andou, andou, atravessando a imensa noitidão".

Em A chuva pasmada, o autor invoca a natureza - o sol, o rio, os pássaros, os peixes, as nuvens - e seus fenômenos, como a chuva.

Era o falar altissonante de quem não ouve e receia não ser escutado. Que tinha visto um peixe subindo nos céus, imitando o vôo de um pássaro. Os da casa riramse: o avô e seus delírios. Mas eu gostei de acreditar e, no meu pensamento, já cardumes atravessavam as nuvens, rebrilhando entre a sarapintada claridade.

Espreitávamos na janela: era uma chuvinha suspensa flutuando entre céu e terra. ${ }^{26}$

A metáfora construída - "uma chuvinha suspensa flutuando entre céu e terra" -remete à abertura, por meio da qual se tornou possível a passagem de uma região cósmica a uma outra.

Em várias estórias, entre as quais $A$ Varanda do frangipani, também se remete à árvore, ali considerada como lugar de passagem dos mortos até adquirirem nova vida.

\footnotetext{
${ }^{23}$ BARROS, Manoel. Livro sobre o nada. 12.ed., Rio de Janeiro, Record, 2006. p. 32.

${ }^{24}$ BARROS, Manoel. Cantigas por um passarinho à toa. Rio de Janeiro, Record, 2003. p.14.

${ }^{25}$ COUTO, Mia. Il. Danuta Wojciechowska. O gato e o escuro. 8.ed., Lisboa, Editorial Caminho, 1987. p.8.e 11.

${ }^{26}$ COUTO, Mia. A chuva pasmada. Lisboa, Editorial Caminho, 2004. p. 24 e 6.
} 
Em O Sagrado e o profano, Mircea Eliade ${ }^{27}$ define o sistema do mundo das sociedades tradicionais: a) um lugar sagrado constitui uma ruptura na homogeneidade do espaço; b)esta ruptura é simbolizada por uma abertura, por meio da qual se tornou possível a passagem de uma região cósmica a uma outra (do Céu à Terra e vice-versa; da Terra para o mundo inferior);c)a comunicação com o Céu expressa indiferentemente por um certo número de imagens referentes todas elas ao 'axis mundi': pilar (cf. a 'universalis columna'), escada (cf. escada de Jacob), Montanha, Árvore, liana etc.; d) em torno deste eixo cósmico estende-se o mundo(=nosso mundo), por conseqüência o eixo encontra-se ao meio, no umbigo da Terra, é o Centro do Mundo.

Na criação desse mundo outro, qualitativamente distinto do cotidiano, ambos os autores organizam o Caos em um Cosmos análogo ao dos deuses, a fim de satisfazer sua nostalgia ${ }^{28}$ de homem religioso.

Todo homem religioso - reiteramos, religioso no sentido do latim 'religare', ligar ao sagrado - tem a nostalgia de viver em um Cosmos tal como era 'in principio'. O resgate desse instante mítico da criação pode ocorrer pela interferência não só do espaço, mas também do tempo sagrado. Conforme Mircea Eliade ${ }^{29}$ : "visto que o Tempo sagrado e forte é o tempo da origem, o instante prodigioso em que uma realidade foi criada, em que ela se manifestou, pela primeira vez, plenamente - o homem esforçar-se-á por tornar a unir-se periodicamente a esse tempo original.

Esse desejo de reencontrar-se 'in illo tempore' remete à nostalgia da perfeição dos começos, uma nostalgia religiosa, portanto. Resgatar esse tempo é estar perto dos deuses, ter um mundo perfeito.

O projeto político e estético de Manoel de Barros contempla esse tempo primeiro, em que tudo pode vir a ser. O tempo, em sua obra, não tem marcas cronológicas, como as do tempo profano, descontínuo, heterogêneo, de duração ordinária, o tempo monótono do trabalho rotineiro, tempo que gasta, que destrói. 0

\footnotetext{
${ }^{27}$ ELIADE, Mircea. O sagrado e o profano: a essência das religiões. Trad. Rogério Fernandes. Lisboa, Edição Livros do Brasil, s.d. p.50.

${ }^{28}$ Nostalgia, no contexto deste estudo, não tem conotação melancólica e pessimista, mas se trata de um resgate do passado que aponta para o futuro.

${ }^{29}$ ELIADE, Mircea. O sagrado e o profano: a essência das religiões. Lisboa, Edição Livros do Brasil, s.d. p.93.
} 
tempo de Manoel de Barros ${ }^{30}$ é mítico, restaurador das origens, como se exemplifica na passagem:

\begin{abstract}
Eu não amava que botassem data na minha existência. A gente usava mais era encher o tempo. Nossa data maior era o quando. O quando mandava em nós. $A$ gente era 0 que quisesse ser só usando esse advérbio.[...] Nesse tempo a gente era quando crianças. Quem é quando criança a natureza nos mistura com as suas árvores, com as suas águas, com o olho azul do céu. Por tudo isso que eu não gostasse de botar data na existência. Por que o tempo não anda pra trás. Ele só andasse pra trás botando a palavra quando de suporte.
\end{abstract}

O tempo para o homem religioso não é nem homogêneo nem contínuo. $O$ tempo sagrado é reversível, recuperável indefinidamente, "é o tempo mítico primordial feito presente"31. Trata-se de um tempo ontológico por excelência, um tempo que não se esgota, porque é circular, eterno presente mítico reintegrado pelo rito. Por exemplo, o tempo da festa, que reatualiza a 'gesta' primordial e satisfaz no homem a necessidade de eternizar-se.

Em O gato e o escuro de Mia Couto, por exemplo, encontramos um tempo cíclico, reversível, em uma narrativa que se refaz permanentemente, porque é circular.

Para o homem não-religioso, essa qualidade sagrada, trans-humana, do tempo é desconhecida, uma vez que ele vivencia diretamente o tempo linear e histórico aniquilador da vida com a própria morte. Dessa forma, pode-se concluir que o tempo sagrado tem o poder de salvar da morte. Isso nos faz lembrar a lendária Sherazade, que, ao longo de mais de mil noites, conseguiu viver por causa de suas estórias maravilhosas. Assim, pôde livrar-se da morte, impedindo que o Xeique Xariar mandasse matá-la, como era seu cruel costume. Isso evidencia que há algo de sagrado nas estórias contadas, ou mesmo no ato de contar ou no ato de ouvir, mas essas questões serão discutidas no momento oportuno.

Sabemos que toda existência começa em um tempo. Ao criar o mundo, criase a dimensão temporal. Tempo e espaço sagrados associam-se e deles é

\footnotetext{
${ }^{30}$ BARROS, Manoel. Memórias Inventadas - A Segunda Infância. São Paulo, Planeta, 2006.

${ }^{31}$ ELIADE, Mircea. O sagrado e o profano: a essência das religiões. Lisboa, Edição Livros do Brasil, s.d. p.81.
} 
necessário se aproximar, de alguma maneira, a fim de alimentar-se dessa fonte primordial que guarda as forças vitais de um verdadeiro nascimento, em um tempo singular, em um mundo 'in statu nascendi'.

Assim como "a cosmogonia é o arquétipo de toda criação, o tempo cósmico que a faz jorrar é o modelo exemplar de todos os outros tempos"32.

\subsubsection{A cosmogonia como arquétipo da criação}

Toda cosmogonia trata do nascimento do mundo, da irrupção do ser para fora do nada, ou a súbita aparição do cosmo a partir do caos. Por tratar da origem absoluta, a cosmogonia é a suprema manifestação do divino e, portanto, pode-se denominá-la Sagrada. Ocupando-se com a irrupção do ser e da vida, a cosmogonia traduz um sentimento universal de transcendência e, ao mesmo tempo, é o gesto exemplar da força e da criatividade.

Fazer bem-feito qualquer coisa, construir, estruturar, formar, tudo isso significa fazer alguma coisa começar a existir, dar vida a algo e, em última instância, fazer algo se assemelhar ao organismo harmonioso por excelência, o Cosmo. Ora, o Cosmo, não custa reiterar, é a obra exemplar dos deuses, é a sua obra-prima.

Segundo Mircea Eliade ${ }^{33}$, a cosmogonia "é o modelo exemplar de toda espécie de fazer". Não só por ser o Cosmo o arquétipo ideal, ao mesmo tempo, de toda situação criadora e de toda a criação, mas por ser uma obra divina, por ser tudo o que é perfeito, pleno, harmonioso, fértil, em uma palavra, por ser tudo o que é sagrado.

Baudelaire ${ }^{34}$ declara: "Um bom quadro, fiel e igual ao sonho que o gerou, deve ser produzido como um mundo".

Alfredo Bosi ${ }^{35}$ explica Arte tendo origem em Ars - ação de fazer junturas entre as partes de um todo. Quase tão antiga quanto o homem, a arte é um fazer, supondo, portanto, trabalho, transformação da "matéria em forma". A criação

\footnotetext{
${ }^{32}$ ELIADE, M. O sagrado e o profano: a essência das religiões. Lisboa: Edição Livros do Brasil, s.d. p.88.

${ }^{33}$ ELIADE, M. apud CHEVALIER, Jean et GHEERBRANT, Allain. Dicionário de símbolos: mitos, sonhos, costumes, gestos, formas, figuras, cores, números. Trad. Vera da Costa e Silva et al. 10.ed., Rio de Janeiro, José Olympio, 1996. p. 295.

${ }^{34}$ BAUDELAIRE apud BOSI, Alfredo. Reflexões sobre a Arte. 2.ed., São Paulo, Ática, 1986. p.13.

${ }^{35}$ BOSI, Alfredo. Reflexões sobre a Arte. 2.ed., São Paulo, Ática, 1986. p. 37.
} 
artística "arranca o ser do não ser, a forma do amorfo, o ato da potência, o cosmos do caos"36.

Para explicar o desconhecido e responder às suas perguntas mais originais, o homem ordena formas e cria mundos por meio da linguagem.

Fayga Ostrower ${ }^{37}$, em Universos da Arte, põe em evidência essa idéia em relação à ciência e à arte:

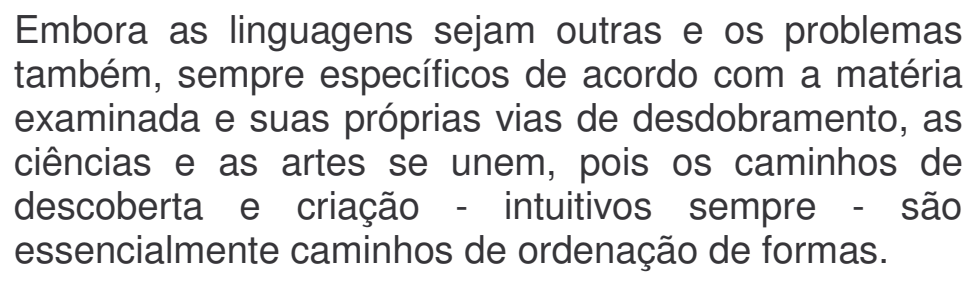

Ao organizar respostas para as hipóteses que formula, um cientista cria um mundo e a cada nova teoria atualiza o ato primeiro da criação. Assim, também, faz o pintor, ao traduzir percepções e sentimentos por meio de cores, de formas, e de cada novo quadro nasce um novo mundo. O músico, igualmente, ordena o caos por meio de cifras musicais; o contador de estórias, ao enredar palavras de um conhecimento ancestral capaz de encantar, o escritor ao fixar em palavras suas mais densas imagens internas: tais ações são atos cosmogônicos, por terem sido criados por eles, repetindo o ato primeiro da criação, aquele acontecido 'ab origine', estando, portanto, fertilizado de sacralidade. Dessa forma, tanto Manoel de Barros quanto Mia Couto, bem como os ilustradores das obras, são criadores, atualizam 0 ato cosmogônico primeiro, sendo suas criações, portanto, sagradas.

Interessante observar que Manoel de Barros parece consciente de que a criação poética é gesto exemplar homólogo à criação do mundo, como sugere: "Experimento o gozo de criar./ Experimento o gozo de Deus"38.

\footnotetext{
${ }^{36}$ BOSI, Alfredo. Reflexões sobre a Arte. 2.ed., São Paulo, Ática, 1986. p. 37. p. 13.

${ }^{37}$ OSTROWER, Fayga. Universos da Arte. 9.ed., Rio de Janeiro, Campus, 1991. p. 59.

${ }^{38}$ BARROS, Manoel. Retrato do artista quando coisa. 4.ed., Rio de Janeiro, Record, 2004. p.21.
} 


\subsubsection{O fazer literário como ato sagrado}

Como criação, o fazer literário engendra um mundo novo, uma ordem qualitativamente distinta do mundo ordinário e um novo homem. Revela Manoel de Barros $^{39}$, no Livro sobre o nada:

O que não sei fazer desmancho em frases.

Eu fiz o nada aparecer.

(Represente que o homem é um poço escuro.

Aqui de cima não se vê nada.

Mas quando se chega ao fundo do poço já se pode ver

o nada.)

Perder o nada é um empobrecimento.

No fazer literário do poeta brasileiro, observa-se que o Cosmo por ele criado é a própria imagem do Caos. O que ele não sabe fazer faz, tanto que surge um Cosmos: o nada. O nada é esse mundo novo e esse novo homem capaz de se enriquecer ao se aproximar das profundezas e das grandezas de seu ínfimo. A ordem por ele criada é admiravelmente inusitada, distinta das relações da vida cotidiana.

O instrumento da criação literária é a Palavra. Mia Couto ${ }^{40}$, em Raiz de Orvalho e outros poemas, aproxima, de maneira surpreendente, o ato de escrever do ato de ver.

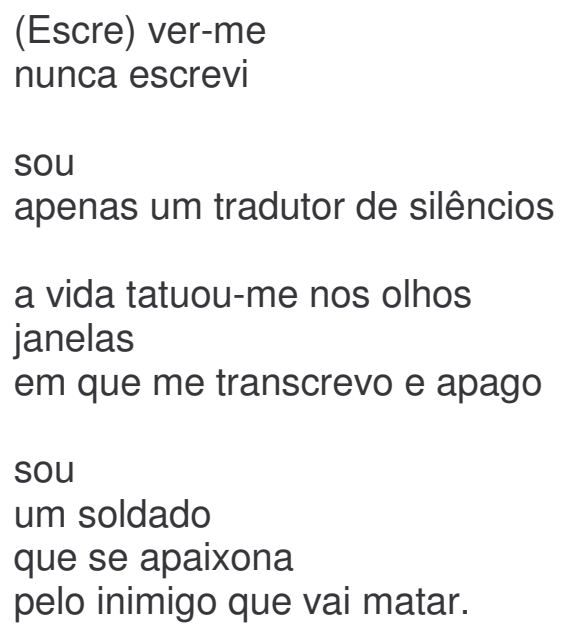

\footnotetext{
${ }^{39}$ BARROS, Manoel. Livro sobre o nada. 12.ed., Rio de Janeiro, Record, 2006. p. 63.

${ }^{40}$ COUTO, Mia. Raiz de orvalho e outros poemas. 3.ed., Lisboa, Editorial Caminho, 1999. p. 60.
} 
O escritor vai modelando imagens e acordando as palavras de seu estado indiferente de dicionário, de sua condição secular para revesti-las de um novo estado em que a significação ganha o mais alto grau de estranhamento.

Ambos os escritores captam o vago e plasmam-no em imagens - 'imago mundi' - revelando transcendência.

Manoel de Barros $^{41}$ resgata a palavra em seu tempo primeiro, em seu momento de "criançamento":

Carrego meus primórdios num andor.

Minha voz tem um vício de fontes.

Eu queria avançar para o começo.

Chegar ao criançamento das palavras.

Lá onde elas ainda urinam na perna.

Antes mesmo que sejam modeladas pelas mãos.

Quando a criança garatuja o verbo para falar o que não

tem.

Pegar o estame do som.

Ser a voz de um lagarto escurecido.

Abrir um descortínio para o arcano.

Mia Couto ${ }^{42}$, igualmente, faz-nos ouvir a voz da infância na "janela do poema":

Assim me debruço

$\mathrm{Na}$ janela do poema

Escolho a minha própria neblina

E permito-me ouvir

O leve respirar dos objetos

Sepultados em silêncio

$\mathrm{E}$ eu invento o que escrevo

Escrevendo para me inventar

E tudo me adormece

Porque tudo desperta

A secreta voz da infância.

Amam-me demasiado

As coisas de que me lembro

E eu entrego-me

Como se me furtasse

À sonolenta carícia

Desse corpo que faço nascer

Dos versos

A que livremente me condeno.

\footnotetext{
${ }^{41}$ BARROS, Manoel. Livro sobre o nada. 12.ed., Rio de Janeiro, Record, 2006. p. 47.

${ }^{42}$ COUTO, Mia. Raiz de orvalho e outros poemas. 3.ed., Lisboa, Editorial Caminho, 1999. p. 40.
} 
De todas as fases da vida, a infância é a representativa desse momento primeiro, desse olhar inaugural sobre o mundo, sobre as coisas que se apresentam para serem descobertas. Desse modo, torna-se possível afirmar que a infância é sagrada, assim como se põe sagrada a palavra em seu estado de infância: ambas instauram o tempo e o espaço inaugural. É o que nos oferece ao olhar Manoel de Barros $^{43}$, no primeiro poema da Parte 1 do livro Poemas rupestres:

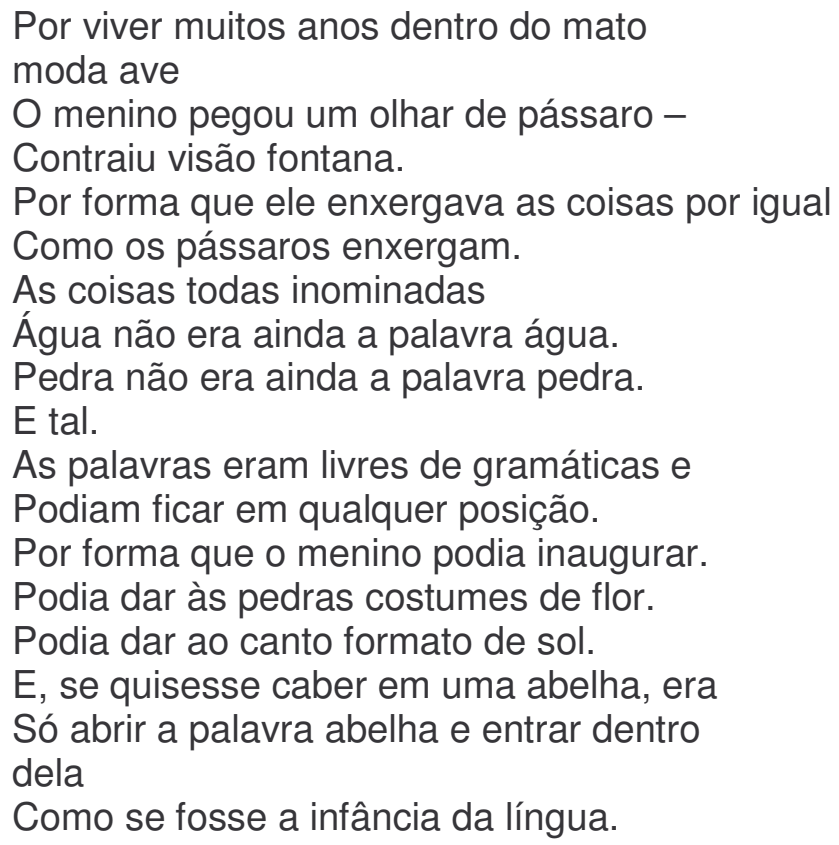

Em muitas culturas, acredita-se que o mundo tenha sido criado pela palavra. $\mathrm{Na}$ tradição cristã, podemos observar o versículo "No Princípio era o Verbo" (João $1,1)^{44}$. Como Arte da Palavra, a Literatura é ato duplamente cosmogônico, pois tanto a arte quanto a própria matéria de que é feita consistem em criação, repetindo, portanto, o ato criador primeiro.

Afirmam os renomados teóricos da literatura, R. Wellek e A. Warren ${ }^{45}$ :

A linguagem é o material da literatura, tal como a pedra
ou o bronze o são da escultura, as tintas da pintura, os
sons da música. Mas importa ter presente que a
linguagem não é uma matéria meramente inerte como
a pedra, mas já em si própria uma criação do homem.

${ }^{43}$ BARROS, Manoel. Poemas Rupestres. Rio de Janeiro, Record, 2007. p.11.

${ }^{44}$ BÍBLIA SAGRADA. Trad. Centro Bíblico Católico. 21.ed., São Paulo, Edição Claretiana, 1975.

${ }^{45}$ WELleK, $R$. e WARREN, A. Teoria da Literatura. Trad. José Palla e Carmo. 5.ed., Lisboa, Europa - América, s.d. 
Mia Couto ${ }^{46}$ ajuda-nos a assinalar a relação do fazer literário com a sacralidade:

A literatura é o território sagrado onde se inventa um chão e nos sentamos com os deuses. O lugar onde, também nós, somos deuses. No momento desta relação, estamos fundando um tempo. E nos religamos com o universo. É isso que torna num momento divino esse pequeno delírio que é o acto de inventar.

\subsubsection{A 'performance' ou a leitura como atos sagrados}

Tratamos, neste momento, de duas situações distintas: uma da 'performance ${ }^{47}$, outra da cultura livresca.

$\mathrm{Na}$ 'performance', contamos com uma experiência artesanal de tradição compartilhada, existe a presença física do contador e do ouvinte. O próprio narrador é um criador, sua matéria-prima é a vida humana, que, por meio de sua voz, gestos, alma, vai sendo artesanalmente bordada.

A atmosfera que circunda essa palavra viva é sagrada. A voz ecoa entre os sons da natureza: pelo corpo do qual emana, pela melodia que faz encantar. $O$ tempo da 'performance' é único. Uma história ancestral é memorizada e transmitida, com espontaneidade, simplicidade, afetividade, por meio de um ser que a anima em um determinado instante.

Essa experiência performática admitida por Johan Huizinga como jogo, implica uma saída do tempo e do espaço ordinários e imersão em um espaço e tempo extra-ordinários.

O lugar da narração torna-se um espaço de criação - como um Centro do Mundo no qual se põe em curso um ritual de iniciação.

Sabe-se que, na Antigüidade, as histórias eram contadas à noite e ao redor do fogo. Luz e sombra, elementos que nos remetem à revelação de algo desconhecido, de uma realidade outra - qualitativamente distinta da cotidiana sagrada, por excelência.

\footnotetext{
${ }^{46}$ COUTO, Mia apud CHAVES, Rita; MACEDO, Tânia (org.) Marcas da diferença: as literaturas de língua portuguesa. São Paulo, Alameda, 2006. p.57.

${ }^{47}$ Conceito recortado de Paul Zumthor. (ZUMTHOR, Paul. A letra e a voz: a "literatura" medieval. Trad. Amálio Pinheiro e Jerusa Pires Ferreira. São Paulo, Companhia das Letras, 1993).
} 
$\mathrm{Na}$ cultura livresca, é visível o processo de dessacralização desse instante único. Primeiramente, por essa relação narrador/ouvinte transformar-se em narrador/leitor; em segundo lugar, por serem ambos intermediados pelo objeto livro.

O narrador, no dizer de Walter Benjamin ${ }^{48}$, em sua atualidade viva, já não está mais presente fisicamente, mas sua voz pode ser percebida pela magia com que ecoa na artesania da letra, quando tratamos dos dois autores estudados neste trabalho. É fato que Manoel de Barros escreve, predominantemente, poesia, mas, mesmo assim, inova com a voz desse narrador primordial.

Guardadas as diferenças entre a cultura oral e a cultura livresca, podemos considerar que tanto ouvir quanto ler permitem reatualizar a magia da voz. Na situação de leitura ou de escuta, o receptor é lançado em um espaço outro, distinto daquele onde está fisicamente.

Mia Couto ${ }^{49}$, em entrevista à Revista Via Atlântica, afirma:

[...] Porque acontece quando estou a ler o Guimarães Rosa ou a Adélia Prado, certos textos me atiram para fora da página, eu tenho que parar porque eu começo escutando vozes que disputam o que está fora do registro gráfico, está para além da página. Eu entro em transe, em trânsito nesse sentido.[...]

O moçambicano faz-nos compreender que esse estado de enlevo ocorre porque a letra se faz dessas vozes, traz sons dessa oralidade que o transporta para um outro lugar e tempo qualitativamente distintos dos da vida ordinária.

$\mathrm{Na}$ situação de leitura tanto da obra de Manoel de Barros quanto de Mia Couto, convoca-se o leitor a celebrar momentos de revelação, epifanias, manifestações do sagrado, também porque as criações, artísticas por excelência, abrigam imagens, gestos, representações humanas universais capazes de colocá-lo em face de um tempo e de um espaço inaugurais. Ali, no limiar da voz ou da página projetada no imaginário, revela-se uma realidade outra, singular, absoluta. Não se penetra em um espaço neutro, mas se constrói um espaço participativo, no qual não se transita por obrigação, mas se penetra livremente, como se entra em um jogo.

${ }^{48}$ BENJAMIN, Walter. Magia e técnica, arte e política: ensaios sobre literatura e história da cultura. Trad. Sérgio Paulo Rouanet. 7.ed., São Paulo, Brasiliense, 1994.(Obras Escolhidas,1). p.197.

49 REVISTA VIA ATLÂNTICA. n 8. São Paulo, Departamento de Letras Clássicas e Vernáculas, Faculdade de Filosofia, Letras e Ciências Humanas, Universidade de São Paulo, 2005, p.214. 
Johan Huizinga ${ }^{50}$ define jogo como um fenômeno cultural que "transcende as necessidades imediatas da vida e confere um sentido à ação". Por encerrar um sentido, "implica a presença de um elemento não material em sua própria essência", ou seja, do espiritual. O jogo "não é vida corrente nem vida real", possui realidade autônoma. Trata-se de "evasão da vida real para uma esfera temporária de atividade com orientação própria". Por ser o jogo desinteressado, ele é capaz de, a qualquer momento, absorver o jogador inteiramente. Distingue-se da vida cotidiana pelo tempo, pela duração que possui, e pelo espaço que ocupa. Pela duração, ele tem um tempo limitado e, ao terminar, prolonga-se como criação do espírito, como tesouro a ser conservado pela memória e, transmitido, torna-se tradição. Quanto ao espaço, também é limitado tanto material quanto imaginariamente. O lugar do jogo é sempre proibido, isolado, consagrado, no qual se respeitam regras, no qual rege uma ordem específica e absoluta.

Enfim, como atividade livre, exterior à vida habitual, capaz de absorver o jogador de maneira intensa e total, como atividade desligada de todo e qualquer interesse material, praticada dentro de limites espaciais e temporais próprios, segundo certa ordem e certas regras, o jogo aproxima-se do sagrado:

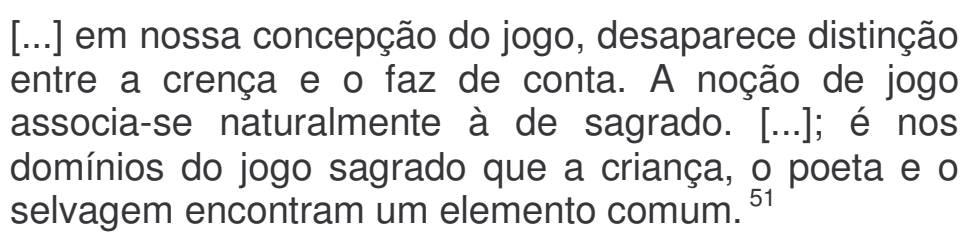

Ler ou ouvir estórias provoca uma saída do Tempo histórico, homogêneo, contínuo e profano para um tempo fabuloso, heterogêneo e sagrado. As expressões "Era uma vez", "Há um tempo", "No princípio", "Um dia”, "No tempo de dantes", "No tempo em que somente os bichos povoavam a terra", "Há muitos anos", "No tempo do quibungo", "Uma feita", ao lado de outros recursos, como o uso do tempo verbal pretérito imperfeito ou mais que perfeito ("Havia um homem", "Era um homem muito pobre"), ou mesmo expressões que resgatam a procedência oral da narrativa mítica ("conta-se que um papagaio fora apanhado", "Dizem que havia antigamente"), tão

\footnotetext{
${ }^{50}$ HUIZINGA, Johan. Homo Ludens. São Paulo, Perspectiva, 1996. p. 4-11.

${ }^{51}$ Idem, ibidem. p. 30.
} 
presentes nos contos, lendas, narrativas tradicionais ou modernas, reiteram essa dimensão sagrada da leitura.

O tempo da leitura apresenta-se como o tempo da festa, da suspensão do ritmo ordinário, tempo cósmico, reversível, tempo exemplar, porque comporta uma criação.

Em concordância com Mircea Eliade ${ }^{52}$ : "Na festa, reencontra-se plenamente a dimensão sagrada da Vida, experimenta-se a santidade da existência humana como criação divina".

\subsection{A Camuflagem do Sagrado}

Para compreender o fenômeno da camuflagem, tal como propõe Mircea Eliade $^{53}$, necessitamos compreender as diferenças que envolvem o homem primitivo e o homem moderno.

O homem primitivo, religioso, porque religado com o sagrado, vive em comunhão com essa dimensão existencial compreendida como transcendente, uma realidade absoluta. Para ele, o Cosmos vive e fala. A própria vida do Cosmos é uma prova da sua santidade, pois ele foi criado pelos deuses e os deuses mostram-se aos homens por meio da vida cósmica. Suas ações e comportamentos são plenos de exemplaridade. Vivendo em um Cosmos aberto, em comunicação com os deuses, ele participa da santidade do universo. Por todo o lado, ele vê uma cifra. Até o gesto mais habitual torna-se um ato espiritual. Afirma o pesquisador do sagrado e do profano que "o homem religioso é sedento de ser" 54 .

Em contrapartida, o homem moderno, não-religioso, porque se desligou aparentemente do sagrado, é o que vive na condição profana, não santificada de homem-natural, ignorante de religiosidade e cego para o espírito. Ele recusa a transcendência, não aceita nenhum modelo de humanidade fora da condição humana, admite a relatividade da realidade e até mesmo duvida do sentido da

\footnotetext{
${ }^{52}$ ELIADE, Mircea. O sagrado e o profano: a essência das religiões. Trad. Rogério Fernandes. Lisboa, Edição Livros do Brasil.s.d. p.102.

${ }^{53}$ Idem, ibidem. p. 211.

${ }^{54}$ Idem, ibidem. p. 76.
} 
existência. Para ele, "o Cosmos se torna opaco, inerte, mudo; não transmite nenhuma mensagem, não é portador de nenhuma cifra" ${ }^{25}$.

Para compreender melhor, vale apresentar um exemplo histórico relacionado com o trabalho agrícola. Como o homem primitivo comunga com a criação do Cosmos, o trabalho agrícola é um ritual revelado pelos deuses ou pelos heróis civilizadores, portanto é real e significativo, assim cabe a ele assegurar a vida das plantas, dos animais; já o homem moderno, como não participa da criação do Cosmos, dele distancia-se, realizando o trabalho como um ato profano, preocupando-se apenas em explorar os recursos econômicos do globo.

Se tomarmos como exemplo, hoje, as culturas brasileiras e africanas, em termos genéricos, podemos considerar que 0 habitante das cidades mais industrializadas comportam-se de maneira similar ao homem moderno a-religioso, conforme definido pelo autor; enquanto o homem do campo, rústico, aproxima-se do homem primitivo e religioso. Cumpre ressaltar que em Moçambique, as fronteiras entre o sagrado e o profano são bem mais porosas do que no Brasil. Isso quer dizer que a convivência do sagrado e do profano torna-se mais perceptível, inclusive nas cidades. O sagrado de Mia Couto desnuda-se muito mais do que o de Manoel de Barros. No brasileiro, percebe-se menção à tradição cristã; no africano, constata-se a concepção da Ancestralidade característica da religiosidade tradicional Bantu.

Em Manoel de Barros: "Um girassol se apropriou de Deus: foi em Van Gogh"56; "usa o livro de São Cipriano contra lascívia, mal de grotas, ferroadas de arraia etc." 57

Em Mia Couto: "Mas o velho tem explicação: à medida que envelhecemos vamos entrando nas intimidades com o sagrado" "58; "Estamos aqui sentados debaixo da árvore sagrada da sua família" ${ }^{\text {"59. }}$.

Mircea Eliade $^{60}$ ressalta que não existe o profano puro, até mesmo a existência mais dessacralizada conserva traços religiosos e ainda reitera que o Sagrado é a criação, a ordem, o ser total sem o qual não se vive. Para o autor, não

${ }^{55}$ ELIADE, Mircea. O sagrado e o profano: a essência das religiões. Trad. Rogério Fernandes. Lisboa, Edição Livros do Brasil.s.d. p. 186.

${ }^{56}$ BARROS, Manoel. O livro das ignorãças. 12.ed., Rio de Janeiro, Record, 2006. p.15.

${ }^{57}$ BARROS. Manoel. O guardador de águas. 5.ed., Rio de Janeiro, Record, 2006. p.17.

${ }_{58}^{58}$ COUTO, Mia. Contos do nascer da terra. 6.ed., Lisboa, Editorial Caminho, 2006. p.74.

${ }^{59}$ Idem, ibidem. p. 115.

${ }^{60}$ ELIADE, Mircea. O sagrado e o profano - a essência das religiões. Lisboa, Livros do Brasil, s.d. p.37. 
existe o puro a-religioso, pois o homem ainda se comporta religiosamente, mesmo sem ter a consciência disso. Há traços da conduta do homem arcaico que persistem nas sociedades mais industrializadas. Ensina: "não se pode viver sem uma abertura para o transcendente, por outros termos não se pode viver no Caos"61.

No entendimento do autor, do qual compartilhamos, não se pode negar que esse homem moderno descende do 'Homo religiosus' e, por isso, conserva vestígios do comportamento religioso, ainda que esvaziados das suas significações conscientes. Observa: "ver-se-á que até a existência mais dessacralizada conserva ainda traços de uma valorização religiosa do mundo".

Mesmo recusando a sacralidade do mundo e assumindo apenas o modo profano de existência - o comportamento religioso não pode ser extirpado, visto ser um aspecto constitutivo do ser humano. Assevera o teórico das religiões: "Certos comportamentos míticos sobrevivem ainda sob nossos olhos. Não que se trate de sobrevivências de uma mentalidade arcaica. Mas determinados aspectos e funções do pensamento mítico são constitutivos do ser humano"62.

A relação do homem com o sagrado é influenciada pela cultura e pela história. A modernidade veio apoiada na idéia de emancipação do homem em relação ao transcendente, ou seja, foi preconizada a morte de Deus e o fim da religião. Assim, o mundo se dessacralizou e o homem se aceita apenas como ser capaz de interferir na história, de transformá-la, pois, liberto de toda heteronomia, pode exercer, com liberdade, sua autonomia.

Suspeitando dessa não religiosidade do homem moderno, o historiador das religiões investiga essa pretensa autonomia, concluindo e demonstrando que, por trás das máscaras do mundo ordinário, da vida profana, escondem-se comportamentos estritamente religiosos, sagrados, tais como nas festas de ano novo, nas personagens míticas que aparecem no cinema, na literatura, nos movimentos de nudismo e de liberdade sexual, entre outros. Até nas idéias de Marx, que se põe avesso a todo tipo de religião, considerando essas manifestações como ópio do povo, o pesquisador mostra a presença de elementos sagrados, como o do papel redentor do justo, do inocente, a luta entre o Bem e o Mal, além do mito da Idade de Ouro, instaurados pela suposta dominação do proletariado.

\footnotetext{
${ }^{61}$ ELIADE, Mircea. O sagrado e o profano: a essência das religiões. Trad. Rogério Fernandes. Lisboa, Edição Livros do Brasil.s.d. p. 47.

${ }^{62}$ ELIADE, M. Aspectos do mito. Lisboa, Edições 70, 1989. p.152.
} 
Ao se referir à arte moderna, aponta o autor, também, para uma recusa do sagrado e para o desinteresse pelos temas religiosos. Explica que o sagrado não é tão facilmente reconhecido como era na arte medieval. Ele se revela por formas dessacralizadas aparentemente, chegando à conclusão de que tanto a destruição de formas quanto a sedução pelo informal carregam significação religiosa. A prosa narrativa, em especial o romance, ocupou, nas sociedades modernas, o lugar da recitação dos mitos e dos contos nas sociedades tradicionais. Temas e personagens mitológicas sobrevivem na literatura: as provas do herói redentor e seus combates contra monstros, as mitologias da mulher e da riqueza. O conto de fadas e o conto fantástico repetem, no plano do imaginário e com outros recursos, os elementos iniciáticos exemplares. O contexto é outro na modernidade, mas subsistem as estruturas exemplares, paradigmáticas que revelam o sagrado. Reaparecem arquétipos, figuras e situações exemplares.

Apesar de o autor tratar da modernidade, consideramos esse mesmo estado de coisas na pós-modernidade. Mesmo onde se pensa não haver sacralidade, 0 sagrado ali se manifesta de maneira sutil.

Justamente ao analisar os comportamentos seculares, ele cunha o termo camuflagem, como um modo, por excelência, de manifestação sutil, pouco perceptível do sagrado.

Camuflar significa dissimular, disfarçar, esconder. Trata-se de um fenômeno que nos parece comum: animais mudam de cor para fugir de predadores, homens se camuflam de verde para não serem descobertos pelos inimigos nas guerras. Entretanto, a camuflagem regida pela dialética do sagrado e do profano, proposta por Mircea Eliade, e a ser comentada a seguir, apresenta-se em sentido mais complexo. Não se trata de um simples ocultamento, mas de um processo sutil de manifestação. Entretanto, o homem moderno e, acrescentamos pós-moderno, não se sente capaz de reconhecer o sagrado e anuncia sua morte, transferindo-o para os estágios primitivos da história do pensamento humano. Mostra o autor:

Esta dificuldade agravar-se-á quando chegar a hora de considerar um símbolo como uma manifestação do sagrado, ou de sentir que as estações, os ritmos ou a plenitude das formas (quaisquer que sejam) são outras tantas modalidades da sacralidade.[...] E na medida em que nos desembaraçarmos dos preconceitos didáticos, em que nos esquecermos de que essas atitudes foram 
por vezes tachadas de panteísmo, de feitiçaria, de infantilismo etc. é que conseguiremos compreender o sentido passado ou atual do sagrado nas culturas arcaicas, e simultaneamente aumentarão as nossas probabilidades de compreendermos igualmente os modos e a história da sacralidade. ${ }^{63}$

O sagrado está sempre saturado de ser. Um comportamento que não tenha um modelo mítico, ou seja, sagrado, revela o caos, é pouco significante. O que é sagrado é transcendente. Transcendente vem de 'trans-ascendere', subir além de, remete ao simbolismo da ascensão e revela os modelos da realidade sensível. É oposto à imanente, que designa o universo das experiências imediatas do mundo sensível, do mundo ordinário. O sagrado manifesta-se no profano, veste, portanto, a roupagem do profano para se manifestar aos homens. Desse modo, para se alcançar o sagrado, essa realidade última, não se deve abandonar o profano, o mundo das experiências, pois é exatamente nele que o sagrado se manifesta, ou seja, o extraordinário se vale das máscaras do ordinário para se manifestar. Essa dialética evidencia a camuflagem do sagrado. Assim, o mundo passa a ganhar significado. Ao decifrar a realidade do mundo, o homem se depara com o mistério. A natureza mostra e esconde o sobrenatural. Em outras palavras, o sobrenatural, o supra-histórico, o extra-ordinário, ao se manifestarem, vestem as roupagens do natural, do histórico, do profano. A irrupção dessa realidade outra revela a plenitude da vida.

Podemos dizer que a hierofania comporta uma tensão entre velamento e desvelamento: "[...] o que revelam todas as hierofanias, até as mais elementares, é esta paradoxal coincidência do sagrado e do profano, do ser e do não-ser, do absoluto e do devir"64.

O sagrado camufla-se quando se manifesta e se manifesta no ato mesmo de se camuflar. Para explicar isso, o autor cunha o conceito de dialética do sagrado e do profano, a ser comentado na seqüência.

\footnotetext{
${ }^{63}$ ELIADE, M. Tratado de história das religiões. São Paulo, Martins Fontes, 1993. p.17.

${ }^{64}$ ELIADE, M. Tratado de história das religiões. São Paulo, Martins Fontes, 1993. p.34.
} 


\subsection{A Dialética do Sagrado e do Profano}

O sagrado é uma realidade complexa. Ela abarca, a um só tempo, o mito, o rito, o símbolo, relacionados à posição do homem diante desse modo de existência e inserido em um momento histórico. Não há fenômeno religioso fora do contexto histórico e sociocultural. O mundo profano e histórico é o suporte para a manifestação do sagrado.

A dialética do sagrado e do profano constitui-se de três momentos:

1. uma ruptura de nível ontológico, ficando estabelecida uma dualidade: sagrado e profano, em que se mostra distinto o objeto hierofânico;

2. uma relação paradoxal entre sagrado e profano, uma coincidência do ser e do não ser, do absoluto e do relativo. Isso quer dizer que o profano funciona como suporte do sagrado. Ao se manifestar a realidade sagrada no mundo profano, ela se historiciza. Ao mesmo tempo, ao se historicizar, quando se manifesta, de alguma forma camufla-se, oculta-se;

3. essa relação sagrado e profano comporta uma dimensão existencial para o 'homo religiosus'. O sagrado confere valor à existência, portanto busca-se, continuamente, estar mais perto dele.

Sagrado e profano jamais se excluem. Isso quer dizer que uma pedra sagrada não deixa de ser pedra, pois nenhuma hierofania pode abolir o mundo profano, porque é exatamente a manifestação do sagrado que institui o mundo, transforma o caos em cosmo. Ao se manifestar a realidade última no mundo profano, ela toma a forma deste mundo e se relativiza, historiciza-se. Essas duas realidades contrárias passam a estabelecer uma relação dialética, da qual se manifesta uma verdadeira coincidência dos opostos, ou seja, os opostos se reconciliam.

O sagrado necessita do profano, do concreto histórico para se manifestar, não se pode apreender o sagrado sem a mediação do profano. Assim, podemos concluir que toda revelação implica ocultação.

A dialética do sagrado e do profano pode ser compreendida como a coexistência paradoxal dos opostos - 'coincidentia oppositorum'.

O livro, como objeto de consumo, participa do mundo profano, do mundo da mercadoria, do universo cultural capitalista, como um produto da indústria editorial. Entretanto, como objeto artístico, ao ser aberto, ao ser contado, ao ser lido, transmuta-se em veículo do sagrado, porque revela uma criação, manifesta algo 
diferente da realidade profana, seja em sua linguagem verbal, seja em sua linguagem visual. Ao mesmo tempo em que se apresenta como objeto profano, constitui-se janela por meio da qual o leitor realiza seu percurso existencial de descoberta, tornando-se espaço para o leitor fazer-se 'homo significans'.

\title{
2.4 O Simbolismo do Sagrado
}

Outro conceito importante para o desenvolvimento deste trabalho é o de simbolismo, porque é pelo símbolo que se apreende o sagrado. Para o estudioso das religiões: "[...] o simbolismo desempenha um papel considerável na vida religiosa da Humanidade; é graças aos símbolos que o Mundo se torna transparente, suscetível de 'mostrar' a transcendência” 65.

É recente a compreensão de que o símbolo, o mito, a imagem pertencem à essência da vida espiritual. É com Mircea Eliade que se torna possível entender a relação que os símbolos possuem com o sagrado. Na visão do referido autor, com a qual compartilhamos, existem motivos, temas, símbolos que resistiram ao tempo, dada sua associação com o caráter universal do sagrado. Hoje, eles aparecem, transformados, camuflados e, em especial, na literatura.

\begin{abstract}
Começamos a compreender hoje algo que o século XIX não podia nem mesmo pressentir: que o símbolo, o mito, a imagem pertencem à substância da vida espiritual, que podemos camuflá-los, mutilá-los, degradá-los, mas que jamais poderemos extirpá-los. Valeria a pena estudar a sobrevivência dos grandes mitos durante o século XIX. Veríamos como, humildes, enfraquecidos, condenados a mudar incessantemente de emblema, eles resistiram a essa hibernação, graças, sobretudo, à literatura. ${ }^{66}$
\end{abstract}

Imagem, símbolo, simbolismos são conceitos elaborados por diversas teorias em diferentes tempos. Entre as teorias, Mircea Eliade critica Freud por traduzir

${ }^{65}$ ELIADE, Mircea. O sagrado e o profano: a essência das religiões. Trad. Rogério Fernandes. Lisboa, Edição Livros do Brasil. s.d. p.140.

${ }^{66}$ ELIADE, Mircea. Imagens e símbolos. Trad. Sônia Cristina Tamer. São Paulo, Martins Fontes, 1996. p.7. 
imagens em termos concretos, reduzindo-as a um único plano de referência e elogia Jung por ter restaurado o sentido espiritual da Imagem.

Mircea Eliade acredita que sonhos, devaneios, imagens de nostalgias, de desejos projetam o ser humano para o domínio do espiritual e o inconsciente é a morada de todo simbolismo. Mostra-nos o autor que os símbolos revelam uma transcendência, são a abertura para uma epifania do espírito: "No irremediável rasgão entre a fugacidade da imagem e a perenidade do sentido que o símbolo constitui, precipita-se a totalidade da cultura humana, como uma mediação perpétua entre a Esperança dos homens e a sua condição temporal” ${ }^{67}$.

Os símbolos são permanentes e inerentes ao homem, ainda que possam mudar vestindo máscaras. Eles revelam aspectos profundos da existência, por isso estudá-los nos possibilita conhecer o homem. Ensina o autor: "se existe uma solidariedade total do gênero humano, ela só pode ser sentida e atuada no nível das Imagens" ${ }^{68}$. Resgatar essas imagens degradadas representa uma possibilidade de renovação espiritual para o homem moderno.

A partir do momento em que o sagrado é retirado da vida religiosa em si, ele permanece ativo pelo simbolismo. Mesmo sem ser compreendido conscientemente em sua totalidade, o símbolo transmite sua mensagem, porque se dirige ao ser humano integral e não apenas à sua inteligência. Assinala o historiador das religiões:

[...] mesmo quando a vida religiosa já não é dominada por deuses celestes, as regiões siderais, o simbolismo uraniano, os mitos e os ritos de ascensão, etc. conservam um lugar preponderante na economia do sagrado. O que está no alto, o elevado, continua a revelar o transcendente em não importa em que conjunto religioso. Afastado do culto, é substituído nas mitologias por intermédio do simbolismo. E este simbolismo celeste infunde e sustenta, por seu turno, numerosos ritos, [...] mitos [...] lendas. ${ }^{69}$

${ }^{67}$ ELIADE, M. apud DURAND, Gilbert. As Estruturas Antropológicas do Imaginário. Trad. Hélder Godinho. São Paulo, Martins Fontes, 1997. p.108.

${ }^{68}$ ELIADE, Mircea. Imagens e símbolos. Trad. Sônia Cristina Tamer. São Paulo, Martins Fontes, 1996. p.13.

${ }^{69}$ ELIADE, Mircea. O sagrado e o profano: a essência das religiões. Trad. Rogério Fernandes. Lisboa, Edição Livros do Brasil, s.d. p.138. 
Acrescenta o autor que o mundo "fala" pelos símbolos, "revela-se". Essa revelação ocorre de diferentes maneiras:

1. os símbolos podem revelar uma modalidade do real ou uma estrutura do mundo que não estão evidentes no plano da experiência imediata.[...]

2. para os primitivos, os símbolos são sempre religiosos, pois visam a algo real ou a uma estrutura do Mundo.[...]

3. uma característica essencial do simbolismo religioso é a multivalência, sua capacidade de exprimir simultaneamente várias significações cuja vinculação não fica evidente no plano da experiência imediata.[...]

4. o símbolo é capaz de revelar uma perspectiva na qual realidades heterogêneas são articuláveis num conjunto ou até mesmo se integram em um sistema.[...]

5. talvez a função mais importante do simbolismo religioso[...] seja sua capacidade de exprimir situações paradoxais ou certas estruturas da realidade última, impossíveis de se exprimir de outra maneira.[...]

6. um símbolo sempre visa a uma realidade ou a uma situação que envolve a existência humana. ${ }^{70}$

O símbolo conserva o contato com as fontes profundas da existência, exprime o "espiritual vivido", por isso não só revela uma estrutura do real ou uma dimensão existencial, mas confere a elas, simultaneamente, uma significação. Graças a ele, a experiência individual é despertada e convertida em ato espiritual.

Os símbolos realizam o arquétipo, definido como modelo exemplar. Assim, para o homem da sociedade tradicional, os modelos para suas instituições e as normas para seus comportamentos teriam sido revelados no começo dos tempos e teriam uma origem transcendental. Ao realizar-se historicamente, o arquétipo assume diferentes máscaras, diferentes significados, mas a estrutura do símbolo permanece. As formas pelas quais se manifesta o arquétipo não são espontâneas, mas grande parte delas é histórica. Uma vez realizada, a forma tende a se libertar do tempo e do lugar e se tornar universal, a reencontrar o arquétipo. Por exemplo, o complexo mágico-religioso do amarrar corresponde a um arquétipo ou a uma constelação de arquétipos, como o tecer do Cosmos, o fio do destino, o labirinto, a corrente da existência, entre outros.

A História pode agregar novas significações ao símbolo, mas nunca modifica sua estrutura na raiz.

${ }^{70}$ ELIADE, Mircea. Mefistófeles e o andrógino. São Paulo, Martins Fontes, 1999. p.220-226. 
As águas simbolizam a soma universal das virtualidades, são o 'fons et origo', o reservatório de todas as possibilidades de existência; elas precedem toda a forma e suportam toda a criação. Em qualquer conjunto religioso, elas conservam essa função regeneradora. Desse modo, a sacralidade das águas, bem como a estrutura das cosmogonias e os apocalipses aquáticos, são revelados pelo simbolismo aquático, sistema capaz de integrar todas as revelações singulares das infinitas hierofanias. É sempre o conjunto simbólico que confere valor às diversas significações das hierofanias.

Para o historiador das religiões, tudo aquilo que o homem manejou, sentiu ou amou pode tornar-se uma hierofania. As hierofanias apresentam-se na vida fisiológica, econômica, espiritual, social. Gestos, danças, brincadeiras infantis, brinquedos, instrumentos musicais, arquitetura, meios de transporte têm origem sagrada: uma vez foram gestos ou objetos cultuais. Todo esse universo mental presente nos mundos arcaicos percorreu os séculos e chegou a nós, ainda que degradados, camuflados, por meio dos mitos, símbolos, costumes. São "fósseis vivos" e basta um deles "para que possamos reconstruir o conjunto orgânico de que ele é o vestígio"71.

A lua tem uma história mítica, o sol, as águas, as plantas, os animais, enfim todo ser cósmico tem uma história e, por isso, fala ao homem e participa de seu universo. O mundo fala por esses elementos e o homem responde pelo imaginário. É esse imaginário, mostra-se grávido de símbolos e de sacralidade.

O símbolo, por revelar transcendência, é capaz de abrir janelas para que penetre a esperança no homem. Observa Gilbert Durand ${ }^{72}$ :

No irremediável rasgão entre a fugacidade da imagem e a perenidade do sentido que o símbolo constitui, precipita-se a totalidade da cultura humana, como uma mediação perpétua entre a Esperança dos homens e a sua condição temporal.

Assim, as simbologias que povoam os textos literários em estudo podem, feito sementes, frutificar no devir. O Sagrado que fulgura nas imagens é capaz de potencializar o desejo humano de uma ação transformadora no porvir. Eis a hipótese

\footnotetext{
${ }^{71}$ ELIADE, M. Tratado de história das religiões. São Paulo, Martins Fontes, 1993. p.16.

72 DURAND, Gilbert. As Estruturas Antropológicas do Imaginário. Trad. Hélder Godinho. São Paulo, Martins Fontes, 1997. p.108.
} 
que nos anima defender. Para justificá-la, relembramos a passagem de Gilbert Durand $^{73}$, que compreende a imaginação como rede de símbolos e imagens, "0 contraponto axiológico da ação [...], é o que vivifica a representação e a torna sedenta de realização [...], é a faculdade do possível, potência de contingência do futuro".

O pensamento racional norteador da ciência desenvolve todos os sentidos humanos para distanciarem o homem do sagrado. Somente pela experiência afetiva, proporcionada pelo império das imagens simbólicas, é que se pode restabelecer o laço do homem, 'animal symbolicum' por natureza, com o mistério da vida.

Para ler essas cifras simbólicas, ora desnudadas, ora camufladas nos textos de literatura propostos, usaremos o aparato teórico proposto por Mircea Eliade. Quando se fizer necessário ampliar sentidos, articularemos com outras significações propostas também por Jean Chevalier e Allain Gheerbrant.

Destacamos, neste capítulo, a importância de algumas contribuições antropológicas de Mircea Eliade para nosso estudo comparado de literatura, entre elas o conceito de sagrado e de profano; a noção de camuflagem; a dialética do sagrado e do profano; e simbolismos - pontos frutíferos de sua hermenêutica dos quais nos beneficiaremos para fundamentar boa parte de nossas interpretações das obras de Manoel de Barros e de Mia Couto.

A seguir, desenharemos nosso segundo eixo teórico, com o qual poderemos nos lançar em nossa travessia pela literatura brasileira e africana.

${ }^{73}$ DURAND, Gilbert. As Estruturas Antropológicas do Imaginário. Trad. Hélder Godinho. São Paulo, Martins Fontes, 1997. p. 433. 


\section{CAPÍTULO 3}

\section{NAS FRONTEIRAS DA LITERATURA COMPARADA}

"só pertencemos ao mundo através de uma comunidade de homens. E só podemos partir para a descoberta de nossa alma utilizando o espelho dos homens que nos olham."

(Michel Maffesoli)

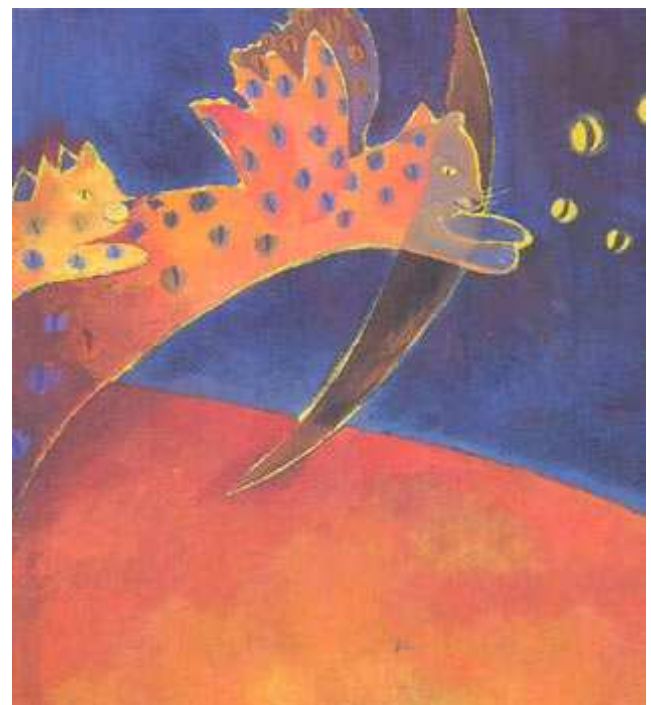




\subsection{Entre nós e os outros}

A Literatura Comparada configura-se, no Brasil e no mundo, como uma área de pesquisa, cujos conteúdos, objetivos e métodos modificam-se continuamente no tempo e segundo as diversas teorias.

Esse campo de trabalho investigativo tão relevante, atualmente, tem sido capaz de nos fornecer explicações sobre questões culturais que envolvem nossa própria identidade, ao lidar com assuntos interliterários, interdiscursivos e interdisciplinares, permitindo, no confronto com o outro, indagarmos sobre nós mesmos, sobre nossa cultura, nossos sonhos, nossas memórias, nossas infindáveis maneiras de nos aventurarmos nessa trajetória tão universal e, ao mesmo tempo, tão particular chamada existência humana.

A investigação dentro dessa área do conhecimento permite-nos relacionar duas ou mais literaturas ou fenômenos culturais, buscando verificar os elementos semelhantes e diferentes, considerando a especificidade de cada autor e de cada texto e os procedimentos criativos que caracterizam a interação deles, amalgamando, assim, aspectos históricos e estéticos. Assim, a Literatura Comparada propicia o diálogo entre as literaturas e as culturas, considerando que o salto qualitativo da crítica literária, hoje, tem sido diluir os marcos teóricos consolidados, uma vez que, em tempo de mundialização, apagam-se as fronteiras.

Nossa época nos leva a refletir sobre uma nova articulação entre universalidade e particularidade. Esse processo conhecido como mundialização, globalização, desterritorialização - de acordo com a mirada teórica - aponta para a unicidade, para a seriação, para a padronização, para a homogeineidade de pensamentos, de idéias, de hábitos. Por isso, colocam-se em evidência, hoje, os discursos avessos a essas ideologias totalizantes, os discursos que tangem a diferenciação, à particularização étnica, social, nacional, sexual. Cabe-nos compreender ser essa configuração do mundo como espaço global um convite a nos fazer pensar sobre as diferenças e sobre as identidades. Para isso, definimos um caminho.

Nosso entendimento da Literatura Comparada segue, por princípio, as pegadas de Antonio Cândido, importante estudioso brasileiro, introdutor da Literatura Comparada no Brasil em 1962, na Universidade de São Paulo, e cuja obra crítica, ampla e densa traz contribuições altamente significativas tanto para o comparatismo 
brasileiro quanto para 0 latino-americano. Antonio Candido ${ }^{74}$ entrelaça, dialeticamente, o aspecto estético ao histórico, concebendo a literatura como sistema articulado que pressupõe interação autor-obra-público e uma continuidade da tradição.

\begin{abstract}
Para compreender em que sentido é tomada palavra formação [...] convém principiar distinguindo manifestações literárias de literatura propriamente dita, considerada aqui um sistema de obras ligadas por denominadores comuns, que permitem reconhecer as notas dominantes de uma fase. Estes denominadores são, além das características internas (língua, temas, imagens), certos elementos de natureza social e psíquica, embora literariamente organizados, que se manifestam historicamente e fazem da literatura aspecto orgânico da civilização. Entre eles se distinguem: a existência de um conjunto de produtores literários, mais ou menos conscientes de seu papel; um conjunto de receptores, formando os diferentes tipos de público, sem os quais a obra não vive; um mecanismo transmissor (de um modo geral, uma linguagem, traduzida em estilos), que liga uns aos outros. O conjunto dos três elementos dá lugar a um tipo de comunicação inter-humana, a literatura, que aparece sob esse ângulo como sistema simbólico, por meio do qual as veleidades mais profundas do indivíduo se transformam em elementos de contato entre os homens, e de interpretação das diferentes esferas da realidade.
\end{abstract}

Em seus pressupostos críticos e metodológicos, acrescenta ser a obra "uma realidade própria" e o contexto, um "sistema de obras"75.

Como realidade própria, a obra de Manoel de Barros, bem como a de Mia Couto, exprimem, cada qual, uma visão de homem, uma posição diante de certos temas por meio dos quais se entrevê "o espírito e a sociedade" ${ }^{\text {"76 }}$. Compreender essa imagem de homem e de sociedade nas duas culturas - brasileira e africana - poderá nos abrir caminhos para entender nosso momento histórico e ideológico, nossa cultura, que se compõe como realidade existencial no limiar deste século.

É nosso intuito, neste trabalho, analisar relações em profundidade, interpretar os textos em seus contextos, avaliar a que necessidades respondem tais relações

\footnotetext{
${ }^{74}$ CANDIDO, Antonio. Formação da literatura brasileira. 8.ed., Belo Horizonte, Itatiaia, 1997. v.1. p.23.

${ }^{75}$ Idem, ibidem. p.29.

${ }^{76}$ Idem, ibidem. p.34.
} 
dentro de cada cultura, pontuando semelhanças e diferenças, pois acreditamos ser essa dinâmica de transformação cultural, de diálogo de culturas e de entrecruzamentos de discursos a força orientadora a nos fazer perceber nossa heterogeneidade. Sabemos não ser esta apenas uma questão de confronto entre o eu e o outro, tampouco uma tarefa de uniformizar culturas. Trata-se, é fato, de salvaguardarmos nossa diferença e compreendermos nossas similitudes. É essa a dimensão que nos impulsiona a atravessar as fronteiras e alargar nosso olhar para nos encontrarmos com os outros e nos outros.

O estudo comparativo das literaturas dos países de língua oficial portuguesa incumbe-se de aproximar e diferenciar produções artísticas com um olhar que ultrapassa divisas nacionais, engendrando um território mais vasto, composto como um "macrossistema" literário, no qual nenhuma das literaturas cabe afirmar-se como paradigmática. Essa noção de "macrossistema" foi assinalada por Benjamin Abdala Junior $^{77}$ e enraíza-se no conceito de sistema literário proposto por Antonio Cândido.

Para Benjamin Abdala Junior, os sistemas nacionais articulam-se, formando um todo, que respeita as especificidades de cada um, funcionando como um aglutinador das literaturas nacionais consideradas em seu aspecto supranacional. Para melhor elucidar o conceito aplicado a nossa pesquisa: a partir da constatação da existência de uma tradição histórico-cultural comum ${ }^{78}$ a esses países, os sistemas literários de Brasil e Moçambique participam do macrossistema literário da língua portuguesa. Como representantes desses sistemas literários, estão Manoel de Barros e Mia Couto.

Por formação, temos uma cultura plural, compartilhamos uma bacia cultural em que a crioulidade ${ }^{79}$ é característica, daí podermos nos imaginar como uma

\footnotetext{
${ }^{77}$ ABDALA JR., Benjamin. De vôos e ilhas: literaturas e comunitarismos. São Paulo, Ateliê Editorial, 2003. p.103.

${ }^{78}$ Para Benjamin Abdala Junior: "qualquer texto literário em português parte de uma linguagem modelada desde a Idade Média européia, num processo contínuo de aproximações e diferenciações que motivou o contexto comunicativo que se estabeleceu a partir dos tempos coloniais. É dentro dessa dinâmica da comunicação em português, que envolveu, historicamente, constantes semelhantes da série ideológica, que podemos apontar para a existência de um macrossistema marcado por um campo comum de contatos entre os sistemas literários nacionais."(ABDALA JR., Benjamin. De vôos e ilhas: literaturas e comunitarismos. São Paulo, Ateliê Editorial, 2003. p.103).

${ }^{79}$ Crioulidade é entendida como um "processo de amalgamento resultante de um contato cultural intenso."(ABDALA JR., Benjamin. De vôos e ilhas: literaturas e comunitarismos. São Paulo, Ateliê Editorial, 2003. p.132).
} 
comunidade ibero-afro-americana, como sonha José Saramago ${ }^{80}$, em Jangada de Pedra. Por isso, cabe-nos esse estudo da literatura baseado em simetrias socioculturais, que assumem uma forma da solidariedade, voltado para o que existe de próprio e de similar nas culturas.

Vale retomar a passagem de Benjamin Abdala Junior ${ }^{81}$ em que esclarece esse pressuposto:

\begin{abstract}
Um olhar simétrico ocorreu com os escritores africanos dos países de língua (oficial) portuguesa. Ao reimaginarem suas nações - um projeto político e cultural - encontraram em nossa literatura uma maneira de ser em que eles próprios se viam. Isto é, descobriram as marcas da crioulidade cultural que nos envolvem e o descentramento de óptica que interessava aos seus projetos político-culturais. Ao buscarem a identificação simbólica com a Mátria (a 'Mamãe-África', profanada pelo colonialismo), dão as costas à simbolização da Pátria (o poder paterno colonial), encontrando algumas de suas marcas na Frátria brasileira.
\end{abstract}

Esse comparatismo da solidariedade tem por missão a troca e a circulação dos repertórios culturais de nossa condição crioula, em confronto com uma globalização estandartizada, unilateral, massificadora que se fecha para as diferenças. Nossa proposta é convite para uma experiência especular, em que uma cultura percebe-se enlaçada com a outra, afinal, diante das virtuosas possibilidades de comunicação atual, é mais que desejável fazer aproximações dessa natureza. Aliás, em consonância com Benjamin Abdala Junior ${ }^{82}$ e na esteira de Boaventura de Sousa Santos, é errôneo denominarmos globalização a um processo perverso como o atual. Deveríamos denominá-lo globalização neoliberal, marcada por um capitalismo neo-selvagem. Globalização pressupõe reciprocidade.

Se, hoje, são destecidos os antigos laços de solidariedade caracterizadores de uma nação, cabe reforçá-los, alternativamente, em âmbito transnacional, pelas

${ }^{80}$ Jangada de Pedra é o romance de José Saramago no qual fica sugerido o sonho com uma comunidade dos países ibero-afro-americanos, singularizados por um imaginário infernal, crioulo, oposto ao imaginário celestial das tradições hegemônicas. A Península Ibérica desgarra-se da Europa e se desloca ao acaso no Oceano Atlântico, como uma ilha em forma de jangada. Com essa imagem, é possível pensar no sonho do comparatismo da solidariedade em que se entrevê essa bacia cultural atlântica que flutua entre a América do Sul e a África Central.

${ }^{81}$ ABDALA JR., Benjamin. De vôos e ilhas: literaturas e comunitarismos. São Paulo, Ateliê Editorial, 2003. p. 68.

${ }^{82}$ Idem, ibidem. p. 78. 
bordas desse universo de múltiplas fronteiras. Fronteiras, evidentemente, não de separação, mas de compartilhamento. Segundo Benjamin Abdala Junior ${ }^{83}$ :

[...] essa perspectiva de fronteiras múltiplas (o homem dividido ou integralizado em pelo menos duas fronteiras), onde ele se desenraíza de sua terra de origem sem se enraizar na terra de origem dos outros, coexistindo com grupos sociais migrantes de outras culturas, pode constituir um hábito crítico. Através desses contatos e ausências, próprios de uma população nômade, em constante circulação e deslocamentos, a identidade afirma-se ainda mais como um constante vir-a-ser, sem um ponto de chegada.

E Mia Couto ${ }^{84}$ confirma:

A nossa riqueza provém da nossa disponibilidade de efectuarmos trocas culturais com os outros. O Presidente Chissano perguntava num texto muito recente o que é que Moçambique tem de especial que atrai a paixão de tantos visitantes. Esse não sei quê especial existe, de facto. Essa magia está ainda viva. Mas ninguém pensa, razoavelmente, que esse poder de sedução provém de sermos naturalmente melhores que os outros. Essa magia nasce da habilidade em trocarmos cultura e produzirmos mestiçagens. Nasce da capacidade de sermos nós, sendo outros. [...] não há cultura humana que não se fundamente em profundas trocas de alma.

E responde, em desafio, Manoel de Barros ${ }^{85}$, no "Caderno de Andarilho", parte do livro Concerto a Céu aberto para solos de ave, em que se lê:

Com esses exercícios os nossos desconhecimentos aumentaram bem.

As coisas sem nome apareciam melhor.

Vimos até que os cantos podem ser ouvidos em

Forma de asas.

${ }^{83}$ ABDALA JR., Benjamin. De vôos e ilhas: literaturas e comunitarismos. São Paulo, Ateliê Editorial, 2003. p. 83.

${ }^{84}$ COUTO, Mia. Pensatempos: textos de opinião. 2.ed., Lisboa, Editorial Caminho, 2005. p.10 e 19.

${ }^{85}$ BARROS, Manoel. Concerto a céu aberto para solos de ave. 4.ed., Rio de Janeiro, Record, 2004. p. 46. 
O nômade ou andarilho é sempre aquele que apaga fronteiras, que alarga margens e horizontes, portanto é capaz de partilhar com todos, de agregar-se a outros. Ele concretiza a proposta de travessia anunciada pela literatura comparada atual. Se nossa época é marcada por uma pretensa democracia erguida sobre as bases da ideologia da indiferença e do individualismo, é na perspectiva da literatura aberta ao comunitarismo e à solidariedade que teremos a possibilidade da transformação e de nos enredarmos em um porvir iluminado pela conjunção entre democracia e humanitarismo. Assim se justifica nosso papel de críticos.

\subsection{Por uma crítica de fronteiras}

Reconhecemos ser a literatura prática simbólica definidora de um espaço cultural híbrido. Nosso pressuposto crítico não é unificar as culturas, nem apenas estabelecer analogias e relações de dependência, tampouco chegar, com tais premissas, à conclusão da dominação cultural, pondo em relevo uma ideologia colonizadora, de superioridade etnocêntrica. Também não pretendemos assumir postura de admiração passiva e incondicional pela cultura do outro, tampouco posicionamento xenófobo. Em contrapartida, buscamos o diálogo de culturas, visando sedimentar um discurso crítico, na medida em que se desvelam interfaces ocultas da diferença.

O recorte investigativo pelo viés do sagrado, nos diferentes contextos literários em estudo, permite-nos abrir janelas do conhecimento e, pela dinâmica do aproximar e do distanciar, torna-se possível definir uma visão crítica das literaturas do Brasil e de África, com o intuito de contribuir, mesmo de forma incipiente, para trocar segredos e apertar laços entre as culturas de que a língua portuguesa é matriz.

Uma autonomia cultural exige assumir capacidade crítica de olhar. Vale relembrar a discussão de Antonio Cândido ${ }^{86}$, em Literatura e sociedade, sobre a dialética do localismo e do cosmopolitismo, em que a identidade cultural se configura como o ponto de chegada dos trabalhos desenvolvidos na linha comparativista.

\footnotetext{
${ }^{86}$ CÂNDIDO, A. Literatura e sociedade. São Paulo: Cia Editora Nacional, 1960.
} 
Ao nos colocarmos diante de cada obra, consideraremos fatores externos, sociais, que a vinculam a um momento histórico; fatores individuais, próprios da consciência criadora, quando se fizerem imprescindíveis; e o texto, capaz de transcender ambos os fatores anteriores, considerando a obra como realidade autônoma. Para relembrar o grande mestre:

\begin{abstract}
Uma obra é uma realidade autônoma, cujo valor está na fórmula que obteve para plasmar elementos nãoliterários: impressões, paixões, idéias, fatos, acontecimentos, que são a matéria-prima do criador. A sua importância quase nunca é devida à circunstância de exprimir um aspecto da realidade, social ou individual, mas a maneira por que o faz. No limite, o elemento decisivo é o que permite compreendê-la e apreciá-la, mesmo que não soubéssemos onde, quando, por quem foi escrita. Esta autonomia depende, antes de tudo, da eloqüência do sentimento, penetração analítica, força de observação, disposição das palavras, seleção e invenção das imagens; do jogo e elementos expressivos, cuja síntese constitui a sua fisionomia, deixando longe os pontos de partida nãoliterários. ${ }^{87}$
\end{abstract}

Compreendendo cada obra como realidade autônoma, procuraremos rastrear apenas os elementos extraliterários considerados necessários para a compreensão.

Associando intuição e investigação, apontaremos, em nossa travessia, uma, entre tantas possibilidades explicativas, pois entendemos que uma obra é sempre plural.

Segundo Antonio Cândido ${ }^{88}$, "toda crítica viva [...] parte de uma impressão para chegar a um juízo" - o que não significa impressionismo, pois é necessário considerar a intuição precedente ao juízo, não concebendo este como "um julgamento puro e simples, mas como avaliação, reconhecimento e definição de valor".

Concordamos com Nelly Novaes Coelho ${ }^{89}$, ao expressar que o valor literário de uma obra não pode ser mensurado por sua pertença a uma ou outra tendência literária, mas "pela consciência do fazer literário revelado por sua matéria literária, seu corpo verbal; e, também, pela adequação de tal matéria às forças renovadoras

\footnotetext{
${ }^{87}$ CANDIDO, Antonio. Op. Cit. p.33.

${ }^{88}$ Idem, ibidem. p.31.

${ }^{89}$ COELHO, Nelly Novaes. Panorama Histórico da Literatura Infantil/Juvenil. São Paulo: Quíron, 1985. p. 220.
} 
mais atuantes em seu momento de produção". Vale, aqui, ressaltar a idéia de que o contexto ideológico por si não confere valor de renovação à obra se esta não se transfigurar em arte, ou seja, é nosso pressuposto enlaçar o ideológico e o estético.

Propomos dois tipos de leitura: uma horizontal - abordando o conjunto das obras de cada autor, a fim de capturar a cosmovisão que plasmou seu projeto político e estético - e uma vertical - explorando, em profundidade, uma obra de literatura para a juventude, por reunir esse tipo de literatura tanto a linguagem verbal quanto visual, abrindo-nos a oportunidade de analisar o sagrado nas duas linguagens.

Analisaremos, em corte vertical, as obras Poeminhas pescados numa fala de João, do brasileiro Manoel de Barros e O gato e o escuro, do moçambicano Mia Couto.

Mesmo reconhecendo a contemporaneidade dos autores a serem estudados, como o fato de terem tido contato literário, por serem leitores e admiradores das obras um do outro, nossas análises não se centralizarão nessa influência. Optamos pelo distanciamento do estudo de fontes e influências, por entendê-lo carregado de uma carga semântica oriunda da visão positivista, sendo compreendido como causalidade mecânica, determinista, colonialista e etnocêntrica. Propomos considerar essas relações como possíveis diálogos.

Buscamos, igualmente, escolher autores que nos pareceram representativos para nosso objetivo, bem como obras próximas de nosso propósito. A escolha de Manoel de Barros justifica-se pela constatação, em seus textos, de uma forte presença de elementos sagrados, camuflados em simbolismos que se equilibram e pela maneira como os plasma, sem comprometer-se com dogmas, credos ou verdades absolutas, motivando o leitor por um imaginário aberto a múltiplas ligações do homem com o transcendente. Mia Couto foi escolhido por reconhecermos, em seus textos, marcas sagradas de uma religiosidade característica das sociedades tradicionais e por compreendermos a importância de sua obra não só como elemento significativo de construção da identidade moçambicana e até africana, mas também por revelar, em semelhança com Manoel de Barros, uma consciência mágica capaz de impulsionar o leitor a novas descobertas.

Brasil e África compartilham da mesma ecologia cultural, são territórios mestiços, marcados pela pluralidade cultural, pela tensão entre elementos genuínos e elementos impostos culturalmente pela colonização. Acreditamos que a 
aproximação dessas literaturas contribuirá, sobremaneira, para a compreensão dos fenômenos culturais e literários produzidos em língua portuguesa, na tentativa de alinhavar memória e utopia por meio da relação dialética entre o simbólico, o histórico e o estético. O desejo é de criar laços de solidariedade passíveis de extrapolarem as fronteiras nacionais e atingirem o supranacional, como ensina Benjamin Abdala Junior ${ }^{90}$.

Por isso, nosso exercício de Literatura Comparada também pretende ser andarilho, fazer travessias, ler nas fronteiras, na expectativa de, ao fazermos nossa leitura pelas margens, perscrutando elementos que se aproximam e que se distanciam nas duas literaturas, podermos compreender culturas vizinhas, cujos processos históricos e formação atribuem-lhes traços similares, sobretudo em termos de imaginário. É nossa pretensão que essa crítica das fronteiras extrapole, de fato, as fronteiras críticas, pois transitamos entre as cercanias da Antropologia e as margens da Literatura.

Compreendemos "fronteira" como lugar de relação - de culturas e de áreas de conhecimento - cruzamento inusitado de influxos e de transformações. Mais do que prender o conhecimento em territórios seguros, ousamos tangenciar limites, obviamente em uma travessia incerta, correndo risco de ilusão e erro. Mesmo assim e exatamente por isso, optamos por essa aventura, dividindo esperanças com Edgar Morin ${ }^{91}$ :

\section{[...] é nas certezas doutrinárias, dogmáticas e intolerantes que se encontram as piores ilusões; o contrário, a consciência do caráter incerto do ato cognitivo constitui a oportunidade de chegar ao conhecimento pertinente [...] o conhecimento é a navegação em um oceano de incertezas, entre arquipélagos de certezas.}

Assim, indisciplinada, nossa investigação, configurada como travessia, fulgura como experiência sagrada, como ritual de iniciação e de passagem, implicando mudança radical de regime ontológico. Mircea Eliade ${ }^{92}$ chama a atenção para o fato de que "a existência humana chega à plenitude por uma série de ritos de passagem,

\footnotetext{
90 ABDALA JR., Benjamin. De vôos e ilhas: literaturas e comunitarismos. São Paulo, Ateliê Editorial, 2003. p.79.

${ }^{91}$ MORIN, Edgard. Os sete saberes necessários à educação do futuro. São Paulo, Cortez, 2003.

92 ELIADE, Mircea. O sagrado e o profano: a essência das religiões. Trad. Rogério Fernandes. Lisboa, Edição Livros do Brasil.s.d. p.188.
} 
em suma, por iniciações sucessivas”. (Essa tem sido uma das mais espessas). 0 mais curioso é ela ter como um dos guias um animal, um verdadeiro 'psicopompo', chamado Pintalgato, do livro $O$ gato e o escuro de Mia Couto, a ser analisado do decurso deste trabalho. 


\section{CAPÍTULO 4}

\section{MANOEL DE BARROS}

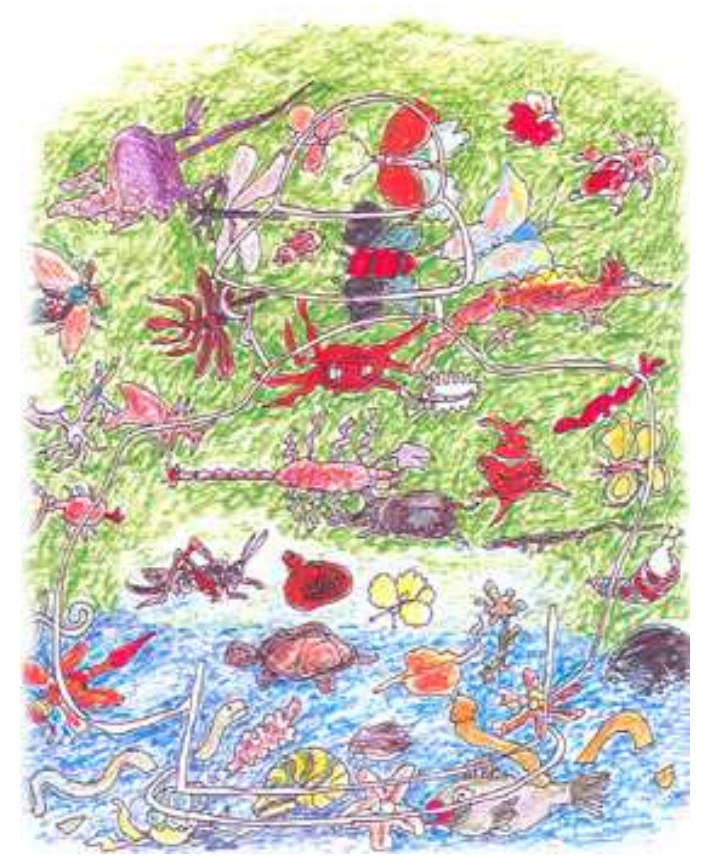

Ilustração 5 - arte de Millôr Fernandes para Retrato do artista quando coisa, de Manoel de Barros (2004)
"Eu sou dois seres.

O primeiro é fruto do amor de João e Alice.

O segundo é letral:

É fruto de uma natureza que pensa por imagens,

Como diria Paul Valéry.

O primeiro está aqui de unha, roupa, chapéu

$E$ vaidades.

O segundo está aqui em letras, sílabas, vaidades

Frases

E aceitamos que você empregue o seu amor em nós.

(Manoel de Barros) 


\subsection{Da janela do trem}

Convido, agora, o leitor, para "transver" em viagem, ou para vivenciar em travessia imaginária, a obra de Manoel de Barros. É da janela do trem que visualizaremos a paisagem poética desenhada por esse autor mato-grossense, nascido em 1916 e portador consagrado das vozes da origem.

Enquanto as janelas permanecem cerradas, olhemos, com minúcia, a paisagem interna - a sociedade que nos governa: informação; revolução tecnológica; aceleração intensa do processo de mundialização, apoiado na ideologia neoliberal, impositora de um pensamento unívoco; desterritorialização; enfraquecimento dos Estados nacionais - tudo isso enraizado em um sistema capitalista de abrangência planetária.

A chamada globalização constitui-se ponto alto do processo de internacionalização do capitalismo presidido pelos avanços da ciência e pelas técnicas da informação. Segundo Milton Santos $^{93}$, os fatores que contribuem para explicar esse processo atual são: "a unicidade da técnica, a convergência dos momentos, a cognoscibilidade do planeta e a existência de um motor único na história, representado pela mais-valia globalizada". A técnica da informação desenvolvida por meio da cibernética, da informática e da eletrônica - envolve todo o planeta e garante o comércio, permite a convergência dos momentos, a simultaneidade das ações e assegura a imposição da mais-valia global - motor único da história.

A ideologia de um mundo só e da aldeia global cria um tempo real considerado patrimônio coletivo da humanidade, no interior do qual se mundializaram as mercadorias - os produtos, o dinheiro, o consumo - e se coisificam $^{94}$ as pessoas e suas relações. Esse novo mundo oferece ao homem a possibilidade de conhecer todo o planeta por meio do computador com o qual se torna possível controlar os espíritos, a fim de sustentar a tirania do dinheiro e da informação, legitimadas pelo "pensamento único", acelerando os processos hegemônicos. Esse pensamento único é regido por regras e dá sustento a novos

\footnotetext{
${ }^{93}$ SANTOS, Milton. Por uma outra globalização: do pensamento único à consciência universal. 7.ed., Rio de Janeiro, Record, 2001. p. 24.

${ }^{94}$ O termo "coisificar" possui valor negativo nesse contexto, tendo como sinônimo reificar, diferente do sentido sugerido por Manoel de Barros a ser compreendido no decurso deste trabalho.
} 
totalitarismos, ou globalitarismos - mais do que globalização ${ }^{95}$, vivemos momentos de globalitarismos.

A desterritorialização, tão celebrada atualmente, apresenta como característica o suposto apagamento das fronteiras e a aparente emergência de uma cidadania universal - que pretensamente ampliariam a liberdade de viver. 0 neoliberalismo é o fundamento da idéia de democracia nesse contexto. Vivemos, hoje, é evidente, a democracia de mercado, não a democracia plena.

A monetarização da vida cotidiana transformou tudo em valor de troca, de maneira que as pessoas acabaram por alimentar seu imaginário com cifras reprodutoras da lógica escrava do funcionamento desse sistema, apoiado na racionalidade, na ciência e na previsibilidade.

Lembrando Milton Santos ${ }^{96}$ :

\begin{abstract}
Como as técnicas hegemônicas atuais são, todas elas, filhas da ciência, e como sua utilização se dá ao serviço do mercado, esse amálgama produz um ideário de técnica e do mercado que é santificado pela ciência, considerada, ela própria, infalível. Essa, aliás, é uma das fontes do poder do pensamento único. Tudo o que é feito pela mão dos vetores fundamentais da globalização parte de idéias científicas, indispensáveis à produção, aliás acelerada, de novas realidades, de tal modo que as ações assim criadas se impõem como soluções únicas.
\end{abstract}

Desenvolve-se, nesse insidioso sistema da tecnociência, toda sorte de individualismos que sustentam a competitividade. Circundam-nos e comandam-nos objetos. Produz-se o interessante ao mercado, não à humanidade. Rapidez, fluidez, velocidade são as bandeiras. Circulam cada vez mais mercadorias, dando-nos, continuamente, a sensação de escassez e o sentimento de necessidade.

Essa é a sociedade que nos envolve, atualmente, e compõe o paradigma97, com base no qual a maior parte dos homens pensa, sente e age.

${ }^{95}$ Conforme Benjamin Abdala Junior, "é errôneo, nesse sentido, designarmos de globalização esse processo perverso. Globalização pressupõe reciprocidade [...]" (ABDALA JR., Benjamin. De vôos e ilhas: literaturas e comunitarismos. São Paulo, Ateliê Editorial, 2003. p.78).

${ }^{96}$ SANTOS, Milton. Op. Cit. p. 53.

${ }^{97}$ Para Edgar Morin, um paradigma pode ser definido por uma "promoção e seleção de conceitosmestres da inteligibilidade"; pela determinação das operações lógicas-mestras. Assim, as pessoas pensam, sentem e agem de acordo com o que está inscrito culturalmente nelas. (MORIN, Edgar. Os sete saberes necessários à educação do futuro. 8.ed., São Paulo,Cortez, 2003. p. 24). 
Agora, abramos as janelas do trem em movimento para nos sentirmos invadidos por uma outra paisagem, para sermos penetrados por um ar mais puro, para nos percebermos ventilados por novas brisas, para ouvirmos o ressoar dos cantos sagrados da natureza sonhada por Manoel de Barros. Um cenário diverso nos atravessa. Nele, podemos escutar a "canção do ver"98, pois, na visão, tudo se transforma, visto ser o olhar o lugar da reconciliação: "é pelo olho que o homem floresce" $" 99$, como ensina Manoel de Barros ${ }^{100}$ :

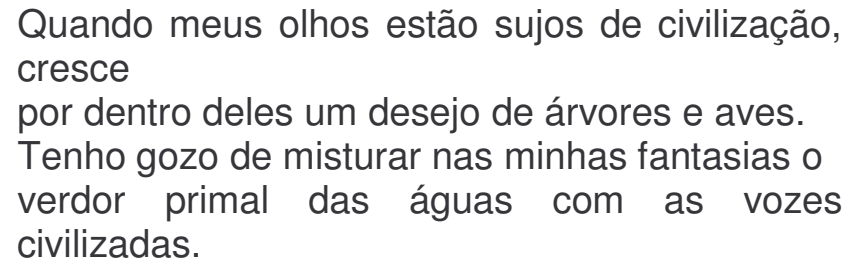

Árvores, aves, águas, pedras, toda a natureza compõe-se como ventre poético do qual nasce o encantamento da letra desse raro escritor. É a maneira de ele fazer sua poesia amanhecer. Passa em revista os valores impostos pelo capitalismo e os recusa; cria objetos-coisas, que não são mercadorias, pois não possuem valor de troca para o sistema:

\section{O fazedor de amanhecer}

Sou leso em tratagens com máquina.

Tenho desapetite para inventar coisas

prestáveis.

Em toda a minha vida só engenhei

3 máquinas

Como sejam:

Uma pequena manivela para pegar no sono

Um fazedor de amanhecer

Para usamentos de poetas

E um platinado de mandioca para o

fordeco de meu irmão.

Cheguei de ganhar um prêmio das indústrias

Automobilísticas pelo Platinado de Mandioca.

Fui aclamado de idiota pela maioria

das autoridades na entrega do prêmio.

Pelo que fiquei um tanto soberbo.

E glória entronizou-se para sempre

Em minha existência. ${ }^{101}$

\footnotetext{
${ }^{98}$ BARROS, Manoel. Poemas Rupestres. Rio de Janeiro, Record, 2007. p.21.

${ }^{99}$ BARROS, Manoel. Livro de pré-coisas: roteiro para uma excursão poética no Pantanal. 4.ed., Rio de Janeiro, Record. p.68.

${ }^{100}$ Idem, Ibidem. p.12.

${ }^{101}$ BARROS, Manoel. O fazedor de amanhecer. Rio de Janeiro, Salamandra, 2001.
} 
Sua maior habilidade é inventar "inutensílios" e valorizar os "patrimônios inúteis da humanidade"102, compostos por todas as miudezas que estão em estado de abandono, pois estas asseguram a grandeza do Ser.

Matéria de poesia para o autor são "as coisas que não pretendem, como pedras que cheiram água, homens que atravessam períodos de árvore", "tudo aquilo que nos leva a coisa nenhuma e que você não pode vender no mercado", "tudo aquilo que a nossa civilização rejeita, pisa e mija em cima", "as coisas jogadas fora têm grande importância - como um homem jogado fora", "as coisas sem importância", "o osso da ostra, a noite da ostra"103, o cisco: "O cisco tem agora para mim uma importância de Catedral." "104 Esses seres miúdos são fecundados de sacralidade.

A matéria de sua poesia é sempre coisa arremessada às margens da engrenagem capitalista. Tudo o que é jogado fora do sistema é lançado dentro do poema:

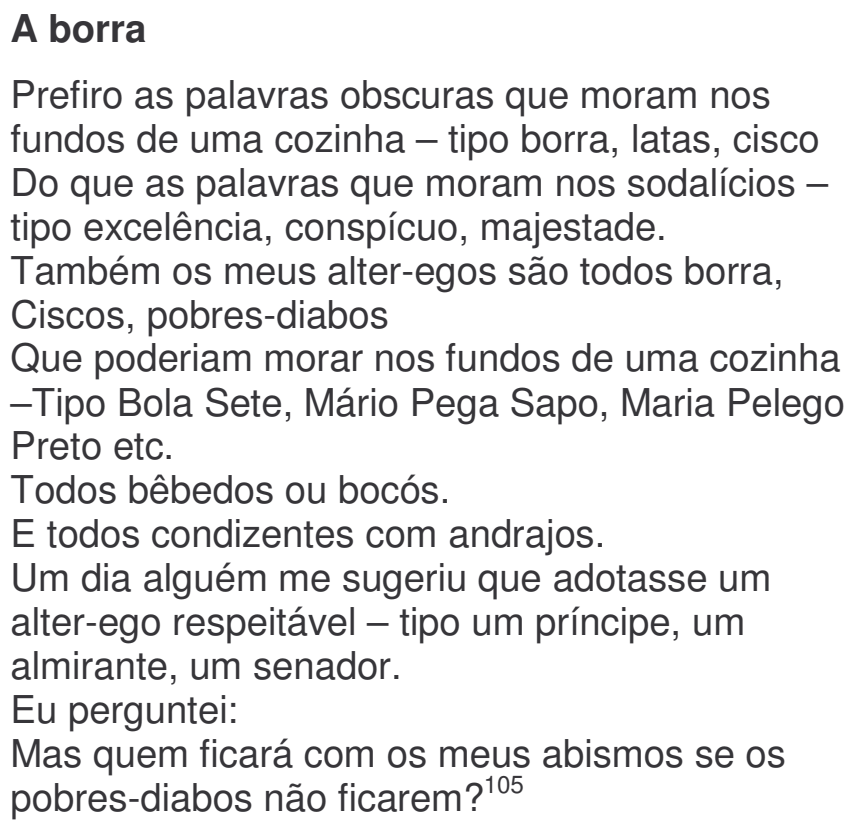

Desvalorizando o universo da "excelência" e do "respeitável", muitas vezes ele faz arranjos poéticos com o que é excrescência, construindo sua cosmogonia poética com elementos grotescos e escatológicos, como: "na Vila não se praticam

\footnotetext{
${ }^{102}$ BARROS, Manoel. Tratado geral das grandezas do ínfimo. 3.ed., Rio de Janeiro, Record, 2005. p. 43.

${ }^{103}$ BARROS, Manoel. Matéria de poesia. 5.ed., Rio de Janeiro, Record, 2005. p.11-15 e 51.

${ }^{104}$ BARROS, Manoel. Retrato do artista quando coisa. 4.ed., Rio de Janeiro, Record, 2004. p 23.

${ }^{105}$ BARROS, Manoel. Ensaios fotográficos. 5.ed., Rio de Janeiro, Record, 2005. p. 61.
} 
latrinas. Donas desabam em urinóis. E os homens no mato [...] As lides de cagar facilitam encontros de amor [...]"106, ou em Memórias Inventadas - A infância ${ }^{107}$, no texto "Obrar", em que utiliza a palavra "obra" de maneira ambígua. Parte do sentido mais profano e mais desprezível, próximo de fezes, e chega a enunciar a grande obra dos homens: não desprezar as coisas desprezíveis nem os seres desprezados. É característica do autor partir de situações cotidianas, profanas, prosaicas, banais para chegar a constatações de alto teor filosófico e existencial e divino.

Nesse mesmo livro, Memórias Inventadas - A Infância, no texto intitulado "Desobjeto", faz de um pente - sem valor de consumo por estar em decomposição matéria de poesia, em composição com a natureza, portanto. Quem o des-cobre é um menino, em um espaço pouco hegemônico: um quintal, e com olhar de poeta:

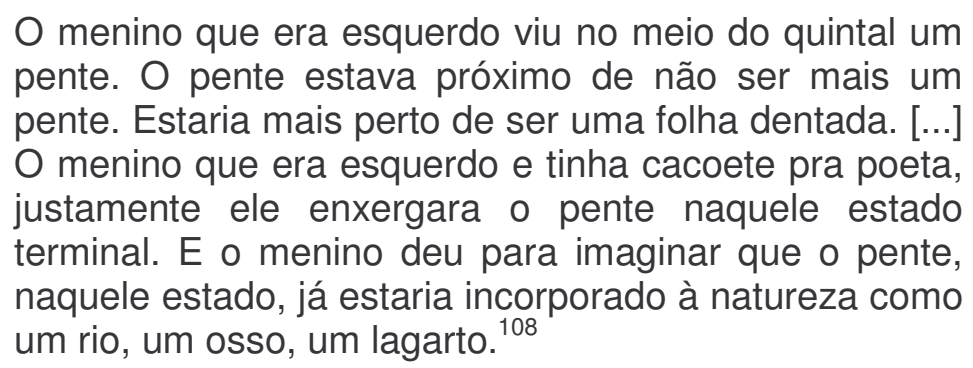

Mais do que apreciar objetos em decomposição, o poeta sugere "desinventar objetos", e é o mesmo pente o objeto a ser desinventado:

\begin{abstract}
Desinventar objetos. O pente, por exemplo. Dar ao pente funções de não pentear. Até que ele fique à disposição de ser uma begônia. Ou uma gravanha.

Usar algumas palavras que ainda não tenham um idioma. ${ }^{109}$
\end{abstract}

Essa proposta reverte não só o valor de troca dos objetos, mas também seu valor de uso. Ademais, analogamente, o escritor transmuta o valor de uso da própria palavra, de modo que ela não sirva mais ao sistema instituído da língua. Essa mudança na função dos objetos e das palavras põe o mundo às avessas e a poesia

\footnotetext{
${ }^{106}$ BARROS, Manoel. Livro de pré-coisas: roteiro para uma excursão poética no Pantanal. 4.ed., Rio de Janeiro, Record. p.73.

${ }^{107}$ BARROS, Manoel. Memórias Inventadas - A Infância. São Paulo, Planeta, 2006.

${ }^{108}$ Idem, Ibidem.

${ }^{109}$ BARROS, Manoel. O livro das ignorãças. 12.ed., Rio de Janeiro, Record, 2006. p.11.
} 
como delírio do verbo. Ironicamente, o autor constrói uma "teologia do traste", consagrando valor mais a uma lata do que a uma idéia:

As coisas jogadas fora por motivo de traste são alvo da minha estima.

Prediletamente latas

Latas são pessoas léxicas pobres porém concretas.

Se você jogar na terra uma lata por motivo de traste: mendigos, cozinheiras ou poetas podem pegar.

Por isso eu acho as latas mais suficientes, por exemplo, do que as idéias.

Porque as idéias, sendo objetos concebidos pelo espírito, elas são abstratas.

$\mathrm{E}$, se você jogar um objeto abstrato na terra por motivo de traste, ninguém quer pegar. Por isso, eu acho as latas suficientes. A gente pega uma lata, enche de areia e sai puxando pelas ruas moda um caminhão de areia. $\mathrm{E}$ as idéias, por ser um objeto abstrato concebido pelo espírito, não dá para encher de areia. Por isso, eu acho a lata mais suficiente. Idéias são a luz do espírito - a gente sabe. Há idéias luminosas - a gente sabe. Mas elas inventaram a bomba atômica, a bomba atômica, a bomba atôm. Agora

eu queria que os vermes iluminassem.

Que os trastes iluminassem. ${ }^{110}$

No texto anterior, o eu poético disserta sobre os motivos que o levam a apreciar mais um objeto-traste - concreto, passível de transformação, reciclável - do que idéias - objetos abstratos, conceituais e causadores de enorme pesar à civilização.

Nesse raciocínio, valoriza mais o pequeno, o ínfimo, o integrado na natureza, compondo com ela uma paisagem primordial, e menos a grande invenção da modernidade:

Achava que os passarinhos são pessoas mais importantes do que aviões.

Porque os passarinhos vêm dos inícios do mundo E os aviões são acessórios. ${ }^{111}$

\footnotetext{
${ }^{110}$ BARROS, Manoel. Poemas Rupestres. Rio de Janeiro, Record, 2007. p. 47.

${ }^{111}$ BARROS, Manoel. Cantigas por um passarinho à toa. Rio de Janeiro, Record, 2003.
} 
Contrapõe-se às máquinas subservientes ao sistema e mostra-se favorável àquelas que, por perderem sua função, tornaram-se imprestáveis e viraram "lixo", porque estas são capazes de prover o homem de sagrado: podem "milagrar flores" e "religar a Deus".

Prefiro as máquinas que servem para não funcionar: quando cheias de areia de formiga e musgo - elas podem um dia milagrar de flores.

(Os objetos sem função têm muito apego pelo abandono.)

Também as latrinas desprezadas que servem para ter grilos dentro - elas podem um dia milagrar violetas.

(Eu sou beato em violetas.)

Todas as coisas apropriadas ao abandono me religam A Deus.

Senhor, eu tenho orgulho do imprestável!

(O abandono me protege. $)^{112}$

O trabalho - que, à luz do sistema capitalista, é concebido como "atividade produtiva subordinada a um fim"113, criador de mercadorias dotadas de valor-de-uso e de valor de troca voltados para o mercado - é reinventado nas formas de sua concepção primeira, como fazer transformador da natureza, como "transfazer". O trabalho aparece como um cultivar, um cuidar, um verdadeiro servir à natureza, revelando por este profundo respeito e adoração.

Tenho de transfazer a natureza. À força de nudez o ser inventa. [...] No meu serviço eu cuido de tudo quanto é mais desnecessário nessa fazenda. Cada ovo de formiga que alimenta a ferrugem dos pregos eu tenho de recolher com cuidado. Arrumo paredes esverdeadas pros caramujos foderem. Separo os lagartos com indícios de água dos lagartos com indícios de pedra. Cuido das larvas tortas. [...] Amo desse trabalho. Todos os seres daqui têm fundo eterno. ${ }^{114}$

\footnotetext{
${ }^{112}$ BARROS, Manoel. Livro sobre o nada. 12.ed., Rio de Janeiro, Record, 2006. p.57.

${ }^{113}$ MARX, K. O capital: Crítica da Economia Política. v.1. Trad. Reginaldo Sant'Anna. 11.ed., São Paulo, Bertrand Brasil-DIFEL, 1987. p. 49.

114 BARROS, Manoel. Livro de pré-coisas: roteiro para uma excursão poética no Pantanal. 4.ed., Rio de Janeiro, Record, 2003. p. 46.
} 
O tempo da velocidade, articulador da vida do capital, é substituído pelo tempo da natureza, pelo tempo cósmico, pelo ritmo natural de uma tartaruga:

\author{
A tartaruga \\ Desde a tartaruga nada não era veloz. \\ Depois é que veio o forde 22. \\ E o asa-dura (máquina avoadora que imita os \\ pássaros, e tem por alcunha avião). \\ Não atinei até agora por que é preciso andar tão \\ depressa. \\ Até há quem tenha cisma com a lesma ela \\ anda muito depressa. \\ Eu tenho. \\ A gente só chega ao fim quando o fim chega! \\ Então pra que atropelar? ${ }^{115}$
}

Patrimônio para o poeta compõe-se de anti-bens, de anti-mercadorias:

Os bens do poeta: um fazedor de inutensílios, um travador de amanhecer, uma teologia do traste, uma folha de assobiar, um alicate cremoso, uma escória de brilhantes, um parafuso de veludo e um lado primaveril. ${ }^{116}$

Se o mundo do capital valoriza a competitividade, com ela o poeta dialoga, compondo um jogo verbal no qual se resgatam as competições infantis desinteressadas:

\title{
Campeonato
}

Nos jardins da Praça da Matriz, os meninos urinavam socialmente.

A gente fazia campeonato pra ver quem mandava urina mais longe.

O menino que mandasse mais longe era campeão.

Mas não havia taça nem medalha.

Umas gurias iam ver por trás dos muros a competição.

Acho que elas tinham alguma curiosidade ou inveja porque não podiam participar do campeonato.

Os meninos ficavam sérios como se estivessem defendendo a pátria naquele momento.

${ }^{115}$ BARROS, Manoel. Tratado geral das grandezas do ínfimo. 3. ed., Rio de Janeiro, Record, 2005. p.33.

${ }^{116}$ BARROS. Manoel. Arranjos para assobio. 4.ed., Rio de Janeiro, Record, 2002. p.31. 
As meninas cochichavam entre elas e corriam de lá pra cá, rindo.

O campeonato só era diferente da Fórmula Um

Porque a gente não tinha patrocinadores. ${ }^{117}$

Recusa os apelos da competitividade capitalista e o progresso científico, por isso acha "mais importante fundar um verso/ do que uma Usina Atômica"118, ou ainda mostra, em voz aguda, que "o cu de uma formiga é também mais importante do que uma Usina Nuclear"119.

Para definir "serviços", passa ao largo da concepção materialista contemporânea (e também da forma instituída para definir os termos nos dicionários - a denotação) e sugere:

Serviços: catar um por um os espinhos da água

Restaurar nos homens uma telha de menos

Respeitar e amar o puro traste em flor. ${ }^{120}$

Prefere os natifúndios aos latifúndios, pois os latifúndios são grandes propriedades pertencentes à aristocracia e configuram-se como geradores da miséria inibidora de uma sociedade mais democrática; já os natifúndios são lugares em que vivem as coisas miúdas, os quase-nada, os trastes capazes de transfigurar as relações humanas:

[...] (Natifúndio é lugar em que nadas

Lugar em que osso de ovo

$\mathrm{E}$ em que latas com vermes emprenhados na boca.

Porém.

[...]

O nada destes natifúndios existe e se escreve com

letra minúscula.)

Se trata de um trastal. ${ }^{121}$

Em Gramática expositiva do chão, Manoel de Barros ${ }^{122}$ denuncia, fortemente, as mazelas do sistema capitalista, marcado pela luta de classes. Expõe essa gramática social que envergonha inclusive o chão brasileiro:

\footnotetext{
${ }^{117}$ BARROS, Manoel. O fazedor de amanhecer. Rio de Janeiro, Salamandra, 2001.

${ }^{118}$ BARROS. Manoel. Arranjos para assobio. 4.ed., Rio de Janeiro, Record, 2002. p.65.

${ }^{119}$ BARROS, Manoel. Livro sobre o nada. 12.ed., Rio de Janeiro, Record, 2006. p.55.

${ }^{120}$ BARROS. Manoel. Arranjos para assobio. 4.ed., Rio de Janeiro, Record, 2002. p.73.

${ }^{121}$ BARROS. Manoel. O guardador de águas. 5.ed., Rio de Janeiro, Record, 2006. p. 14.

${ }^{122}$ BARROS. Manoel. Gramática expositiva do chão. 5.ed., Rio de Janeiro, Record, 2006. p. 46- 47.
} 


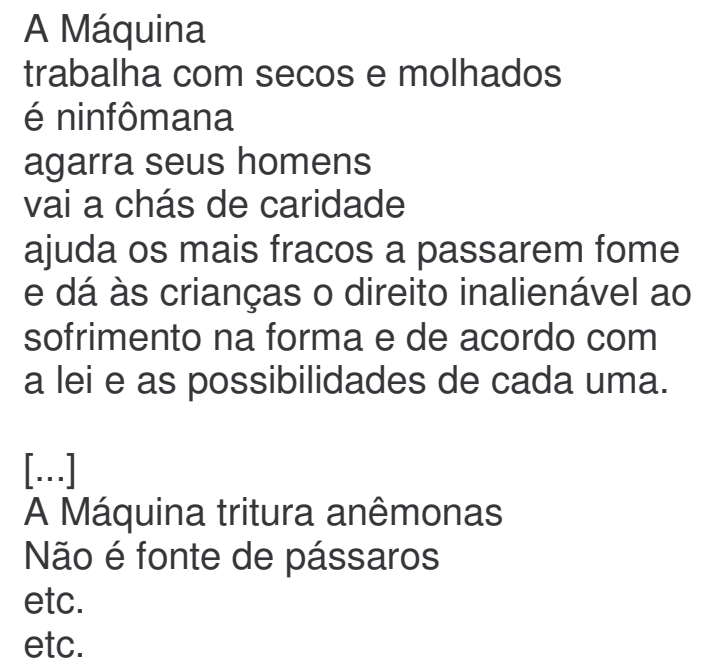

Estudo formal, instrução, academia, livros são alvo de crítica e ironia do autor, pois distanciam o homem do sensível, do poético, da natureza, das fontes e de sua condição verdadeiramente humana.

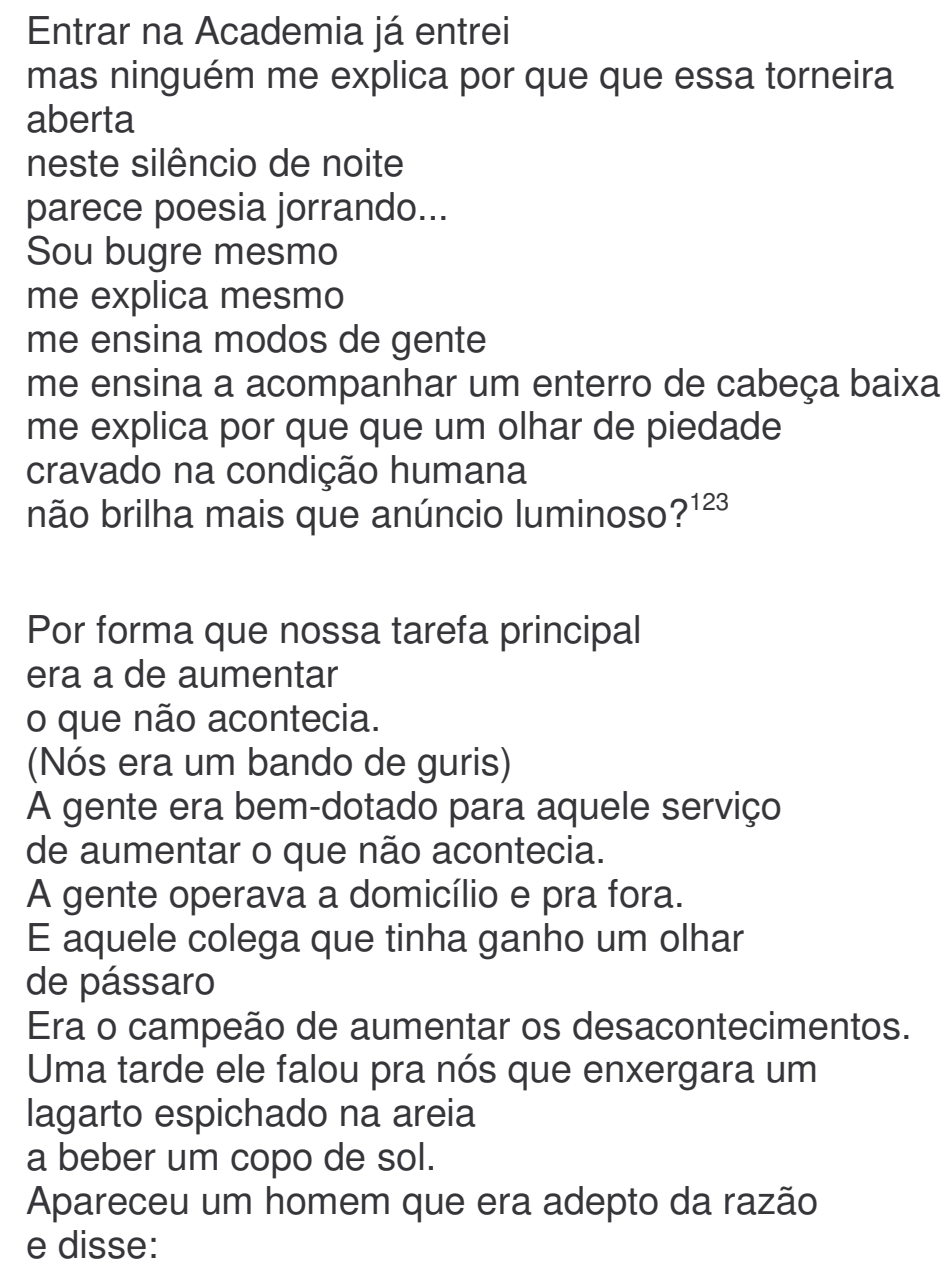

${ }^{123}$ BARROS. Manoel. Poemas concebidos sem pecado. 4.ed., Rio de Janeiro, Record, 2005. p.27. 
Lagarto não bebe sol no copo!

Isso é uma estultícia.

Ele falou de sério.

Ficamos instruídos. ${ }^{124}$

$[\ldots]$

Hoje eu tasquei uma pedra no organismo

do vento.

Depois me ensinaram que vento não tem

organismo

Fiquei estudado. ${ }^{125}$

tudo o que os livros me ensinassem

os espinheiros já me ensinaram.

Tudo que nos livros

eu aprendesse

nas fontes eu aprendera.

O saber não vem das fontes? ? $^{126}$

A ciência - com seus métodos, seus processos classificatórios, seus cálculos - bem como a informação, por afastarem o homem de sua condição divina, é renegada.
A ciência pode classificar e nomear os órgãos de um sabiá
mas não pode medir seus encantos.
A ciência não pode calcular quantos cavalos de força existem
nos encantos de um sabiá.

Quem acumula muita informação perde o condão de adivinhar: divinare

Os sabiás divinam. ${ }^{127}$

As descobertas científicas obscurecem a invenção sagrada maior: o amor e, por isso, são alvo de recusa.

\author{
O amor \\ Fazer pessoas no frasco não é fácil \\ Mas se eu estudar ciências eu faço.[...] \\ Para fazer pessoas ninguém ainda não \\ inventou nada melhor que o amor.
}

\footnotetext{
${ }^{124}$ BARROS, Manoel. Poemas Rupestres. Rio de Janeiro, Record, 2007. p.17.

${ }^{125}$ BARROS. Manoel. Arranjos para assobio. 4.ed., Rio de Janeiro, Record, 2002. p.37.

${ }^{126}$ BARROS, Manoel. Cantigas por um passarinho à toa. Rio de Janeiro, Record, 2003.

${ }^{127}$ BARROS, Manoel. Livro sobre o nada. 12.ed., Rio de Janeiro, Record, 2006. p.53.
} 
Deus ajeitou isso pra nós de presente.

De forma que não é aconselhável trocar

o amor por vidro. ${ }^{128}$

Prefere as palavras de inventar às de informar, afirmando não ser da informática, mas da invencionática, como se constata no texto "O apanhador de desperdícios", do livro Memórias inventadas - A Infância:

Uso a palavra para compor meus silêncios.

Não gosto das palavras

fatigadas de informar.

Dou mais respeito

às que vivem de barriga no chão

tipo água pedra sapo.

Entendo bem o sotaque das águas.

Dou respeito às coisas desimportantes

e aos seres desimportantes.

Prezo insetos mais que aviões.

Prezo a velocidade

das tartarugas mais que a dos mísseis.

Tenho em mim esse atraso de nascença.

Eu fui aparelhado

para gostar de passarinhos.

Tenho abundância de ser feliz por isso.

Meu quintal é maior que o mundo.

Sou um apanhador de desperdícios:

Amo os restos

como as boas moscas.

Queria que a minha voz tivesse um formato de canto.

Porque eu não sou da informática:

eu sou da invencionática.

Só uso a palavra para compor meus silêncios ${ }^{129}$.

É na negação de uma cultura legitimada pelo saber livresco e doutrinário que sua obra ganha transcendência, tornando-se um verdadeiro oráculo impresso, grávido de revelações do que há de mais íntimo, de mais essencial, de mais secreto, de mais invisível, de mais anônimo, de mais sagrado. 'Númen' poético, sua obra celebra e consagra a comunhão do homem com a natureza.

\section{Formigas}

Não precisei de ler São Paulo, Santo Agostinho,

São Jerônimo, nem São Tomás de Aquino, nem São

Francisco de Assis -

\footnotetext{
${ }^{128}$ BARROS, Manoel. O fazedor de amanhecer. Rio de Janeiro, Salamandra, 2001.

${ }^{129}$ BARROS, Manoel. Memórias Inventadas - A Infância. São Paulo, Planeta, 2006.
} 
Para chegar a Deus.

Formigas me mostraram ele.

(Eu tenho doutorado em formigas. $)^{130}$

Recusa, igualmente, o raciocínio lógico cartesiano, que sustenta a ciência, argumentando: "Quem não tem ferramentas de pensar, inventa"131.

Sua invenção nega o pensar abstrato, adulto, conceitual e enaltece a ignorância, prima pelo pensar infantil, mágico, concreto, primitivo - que enlaça o selvagem, o poeta e a criança:

O rio fazia uma volta atrás de nossa casa era a

imagem de um vidro mole que fazia uma volta atrás da casa.

Passou um homem depois e disse: Essa volta que o

rio faz por trás de sua casa se chama enseada.

Não era mais a imagem de uma cobra de vidro que

fazia uma volta atrás de casa.

Era uma enseada.

Acho que o nome empobreceu a imagem. ${ }^{132}$

Esse pensar mágico é feito por analogias, como bem define: "Do que não sei o nome guardo as semelhanças ${ }^{133}$. Conforme Alfredo Bosi ${ }^{134}$, "pela analogia, o discurso recupera, no corpo da fala, o sabor da imagem. A analogia é responsável pelo peso da matéria que dão ao poema as metáforas e as demais figuras."

As principais metáforas e analogias criadas pelo autor associam-se ao reino vegetal, animal e mineral, pois considera sabedoria o que vem desses três reinos sagrados:

Pertenço de fazer imagens.

Opero por semelhanças.

Retiro semelhanças de pessoas com árvores de pessoas com rãs de pessoas com pedras etc.etc.

Retiro semelhanças de árvores comigo.

$[\ldots]$

Preciso obter sabedoria vegetal.

\footnotetext{
${ }^{130}$ BARROS, Manoel. Ensaios fotográficos. 5.ed., Rio de Janeiro, Record, 2005. p.55.

${ }^{131}$ BARROS, Manoel. O fazedor de amanhecer. Rio de Janeiro, Salamandra, 2001.

${ }^{132}$ BARROS, Manoel. O livro das ignorãças. 12.ed., Rio de Janeiro, Record, 2006. p.25.

${ }^{133}$ Idem, Ibidem. p.45.

${ }^{134}$ BOSI, Alfredo. O ser e o tempo da poesia. 6.ed., São Paulo, Cia das Letras, 2000. p.38.
} 
$[\ldots]$

E quando esteja apropriado para pedra, terei também sabedoria mineral. ${ }^{135}$

Por meio desse pensamento mágico, o poeta desmonta e reverte a lógica cartesiana, redutora do sensível ligado ao corpo e enaltecedora do sentido associado à mente, assim como faz a namorada que via errado, personagem do poema "Um olhar", do livro Memórias Inventadas - A Segunda Infância:

\begin{abstract}
Eu tive uma namorada que via errado. O que ela via não era uma garça na beira do rio. O que ela via era um rio na beira de uma garça Ela despraticava as normas [...] Com ela as coisas tinham que mudar de comportamento.[...] Falou por acréscimo que ela não contemplava as paisagens. Que eram as paisagens que a contemplavam. ${ }^{136}$
\end{abstract}

Essa forma enviesada de ver e escrever compõe o exercício de linguagem fundamentado na intuição fantástica ${ }^{137}$ que transborda no poeta. Para a lógica cartesiana, interessa a "frase sem equívocos, cujo ponto de referência obrigatório será o significado claro e distinto", conforme mostra Alfredo Bosi ${ }^{138}$, em $O$ ser e o tempo da Poesia. Entretanto, para Manoel de Barros ${ }^{139}$, essa lógica parece não ter valor, como revela em $\mathrm{O}$ fazedor de amanhecer. "as coisas muito claras me noturnam". Por isso, o poeta resgata o pensamento primitivo. Em Retrato do artista quando coisa ensina-nos uma nova gramática existencial, baseada nesse pensar mágico:

\footnotetext{
${ }^{135}$ BARROS, Manoel. Livro sobre o nada. 12.ed., Rio de Janeiro, Record, 2006. p.51.

${ }^{136}$ BARROS, Manoel. Memórias Inventadas - A Segunda Infância. São Paulo, Planeta, 2006.

${ }^{137}$ Expressão motivada pela teoria de Tzvetan Todorov, em Introdução à literatura fantástica, para o qual o fantástico consiste em uma "hesitação experimentada por um ser que só conhece as leis naturais, face a um acontecimento aparentemente sobrenatural"(TODOROV, Tzvetan. Introdução à literatura fantástica. São Paulo, Perspectiva, 2004. p.31).Ele atesta o mistério, o inexplicável, o inadmissível, a ruptura da ordem estabelecida introduzidos na vida cotidiana. Embora Todorov não aceite o fantástico para a poesia, ressalta-se que o exercício poético de Manoel de Barros aproxima-se da prosa e é preciso considerar que, após o modernismo, os gêneros tornaram-se híbridos - o que não ocorria no contexto de análise de Todorov.

${ }^{138}$ BOSI, Alfredo. O ser e o tempo da poesia. 6.ed., São Paulo, Cia das Letras, 2000. p. 229.

${ }^{139}$ BARROS, Manoel. O fazedor de amanhecer. Rio de Janeiro, Salamandra, 2001.
} 
Uma rã me pedra (A rã me corrompeu para pedra. Retirou meus limites de ser humano e me ampliou para coisa. A rã se tornou o sujeito pessoal da frase e me largou no chão a criar musgos para tapete de insetos e de frades.) ${ }^{140}$,

E continua: "Um passarinho me árvore"; "os jardins se borboletam"; folhas secas me outonam"141. Esse pensar primitivo, selvagem, concreto difere do pensamento dedutivo, "civilizado", abstrato, conceitual. É por essa abertura ao selvagem que ele incursiona nos terrenos do sonho, do onírico, do surreal, no interior do qual tudo pode acontecer.

Dessa maneira, seus textos brincam com a lógica e a subvertem, desafiandonos a rever certezas e a esperar o inesperado. Em O guardador de águas, ele, enuncia como subtítulo: "Seis ou treze coisas que eu aprendi sozinho" ${ }^{142}$, quando, de fato, propõe 14 coisas. Em Arranjos para assobio, afirma o poeta arrolar sete inutensílios de Anicieto retirados da mitologia indígena ${ }^{143}$, mas apresenta apenas seis.

É comum valer-se do ilogismo, também, para tratar de sua busca interior:

Passei anos me procurando por lugares nenhuns.

Até que não me achei - e fui salvo.

Às vezes caminhava como se fosse um bulbo. ${ }^{144}$

Como resposta ao malfadado presente marcado pela racionalização, Manoel de Barros inventa uma gramática cubista e surreal, na qual se criam casamentos insólitos entre imagens e vocábulos, e reúne, em seu poetar único, fragmentos nascidos de sua visão singular e de seu sentir de instrumentista, capaz de compor sons-imagens inaugurais. Assim, coloca em suspenso valores estruturantes do paradigma da razão ocidental e aponta para uma nova possibilidade de verdade entrevista nos horizontes da intuição, na convivência entre o visível e o invisível, no entrelaçamento do profano e do sagrado.

\footnotetext{
${ }^{140}$ BARROS, Manoel. Retrato do artista quando coisa. 4.ed., Rio de Janeiro, Record, 2004. p.13.

${ }^{141}$ Idem, ibidem. p.13-14.

${ }^{142}$ BARROS. Manoel. O guardador de águas. 5.ed., Rio de Janeiro, Record, 2006.

${ }^{143}$ BARROS. Manoel. Arranjos para assobio. 4.ed., Rio de Janeiro, Record, 2002. p.53.

${ }^{144}$ BARROS. Manoel. Concerto a céu aberto para solos de ave. 4.ed., Rio de Janeiro, Record, 2004. p.17.
} 
Ao analisarmos, brevemente, os títulos de seus livros, observamos essa composição inusitada: Compêndio para uso dos pássaros; Gramática expositiva do chão; Livro de pré-coisas; O livro das Ignorãnças; Livro sobre o nada; exercícios de ser criança; ensaios fotográficos; Tratado Geral das Grandezas do ínfimo. Ele utiliza palavras do mundo da ciência, da escrita, do adulto, sensivelmente combinadas com o inesperado. Esse imprevisível evoca sempre o que se institui como desvalor ou como anti-valor.

Em geral, os títulos associam poesia, música e natureza, como se observa em: Poesias; O guardador de águas; Poesia quase toda; Concerto a céu aberto para solos de aves; Para encontrar azul eu uso pássaros; o fazedor de amanhecer; Poeminhas pescados numa fala de João; Cantigas para um passarinho à toa; Poemas rupestres, levando o leitor a se encontrar com as forças nascentes da cultura, portadoras de sons, imagens, magia, sacralidade.

Nessa busca pelos primórdios, ele escreve, também, Memórias Inventadas a Infância e Memórias Inventadas - a Segunda Infância.

Segundo alude o eu poético em Livro sobre o nada: "O que sustenta a encantação de um verso (além do ritmo) é o ilogismo" ${ }^{145}$. Esse ilogismo abre-nos a possibilidade de criação de um outro paradigma.

Com Manoel de Barros, o mundo não nos é dado pronto, mas nos elege para criá-lo, para realizar o ato cosmogônico que, conforme já enunciamos, é sagrado por natureza.

Propõe-nos o poeta uma leitura pouco disciplinada, não linear, uma leitura que desejamos denominar de andarilha, pois exige um leitor livre para escolher a direção e o sentido, conforme the agradar. As estrofes compostas ora pela enumeração de substantivos, ora por frases curtas e por versos em fragmentos favorecem o desenvolvimento dessa nova qualidade de leitura e de leitor, aprendendo este a lidar com o desconhecido, com o imprevisível, com o incerto, com o surpreendente. Aprende o leitor, também, a ser errante do texto, da lógica imposta, da língua, atravessando o umbral da lei suprema do pensamento racional e atingindo o lugar da anti-lei poética. Sugeriremos, para comprovar nossa idéia, dois textos, retirados de Arranjos para assobio:

${ }^{145}$ BARROS, Manoel. Livro sobre o nada. 12.ed., Rio de Janeiro, Record, 2006. p.68. 
coisinhas: osso de borboleta pedras

com que lavadeiras usam o rio

pessoa adaptada à fome e o mar

encostado em seus andrajos como um tordo!

o hino da borra escova

sem motor ACEITA-SE ENTULHO PARA O POEMA

ferrugem de sol nas crianças raízes

de escória na boca do poeta beira de rio

que é uma coisa muito passarinhal!ruas

entortadas de vagalumes

traste de treze abas em seus favos empedrados de

madeira

sujeito com ar de escolhos inseto

globoso de agosto árvore brotada

sobre uma boca em ruínas

retrato de sambixuga pomba estabelecida

no galho de uma estrela! riacho com osso de fora

coberto de aves pinicando

suas tripas e embostando de orvalho

suas pedras indivíduo que pratica nuvens ACEITA-SE

ENTULHO PARA O POEMA moço que tinha

seu lado principal caindo na água e o outro lado

mais pequeno tocando larvas!

rã de luaçal. ${ }^{146}$

O arranjo poético desse primeiro texto lembra os painéis localizados nos cruzamentos de grandes avenidas, cujos letreiros buscam divulgar produtos e comercializar mercadorias. Não há começo nem fim. Lê-se o que for possível, no tempo do sinal vermelho, sem ordem determinada. Diferente dos painéis publicitários, Manoel de Barros propõe um painel poético, divulgador da necessidade de não-mercadoria, compondo, portanto, um anti-letreiro e uma contrapropaganda.

O segundo texto, sugerido a seguir, apresenta várias possibilidades de leitura, no sentido de cima para baixo, de baixo para cima, do meio para o começo ou para o fim, do começo e fim para o meio, de modo que cabe ao leitor experimentar, brincar de descobrir seus sentidos.

Me abandonaram sobre as pedras infinitamente nu, e

Meu canto reboja.

[meu canto.

Não tem margens a palavra.

Sapo é nuvem neste invento.

Minha voz é úmida como restos de comida.

A hera veste meus princípios e meus óculos.

Só sei por emanações por aderência por incrustações.

${ }^{146}$ BARROS. Manoel. Arranjos para assobio. 4.ed., Rio de Janeiro, Record, 2002. p.29. 
O que sou de parede os caramujos sagram.

A uma pedrada de mim é o limbo.

Nos monturos do poema os urubus me farreiam.

Estrela é que é meu penacho!

Sou fuga para flauta e pedra doce.

A poesia me desbrava.

Com água me alinhavo. ${ }^{147}$

Em geral, como matéria-prima, seus arranjos poéticos têm a frase sintaticamente lógica, mas desarranjada semanticamente, uma vez que reúne, de maneira imprevisível, realidades aparentemente incompatíveis - "sapo é nuvem", "a hera veste meus princípios e meus óculos", "sou fuga para flauta e pedra doce", entre outras.

Ao poetar "sapo é nuvem", utiliza uma aproximação de termos por semelhança, compondo uma metáfora. Ao mesmo tempo, ao revés da estrutura de uma definição científica, estabelece uma equivalência mágica, portadora de um valor de verdade, especialmente para a mente primitiva e para a mente infantil.

Ao compor "a hera veste meus princípios e meus óculos", personifica o vegetal e, simultaneamente, coloca em convivência sensível elementos abstratos (princípios) e concretos (óculos).

Em "sou fuga para flauta e pedra doce", revela sua percepção plural da realidade, ao misturar, de forma sutil, como em um mosaico, elementos de campos semânticos diversos - fuga para flauta doce e pedra. Nessa construção metafórica, reconcilia música e natureza, direcionando essas imagens sensíveis para o íntimo do homem. A música do verso compõe-se não apenas pelos substantivos enunciados - fuga, flauta - mas também pela sonoridade, conjugando sons leves /s/, /f/ - e sons pesados - /p/ /d/, consoantes surdas - /s/, /f/, /p/ - e sonoras - /d/.

Tal experiência com a linguagem, marcada por peraltagens semânticas, sintáticas, sonoras que rompem com o instituído, põe em relevo o ato criador - e sagrado - por parte do autor - e, ao mesmo tempo, favorece o ato recriador igualmente sagrado - por parte do leitor.

Portador desse raro fazer lúdico, Manoel de Barros presenteia-nos com outras obras, nas quais a qualidade de leitor criativo e errante se faz, também, evidente. As obras Memórias Inventadas - A Infância e Memórias Inventadas - A Segunda Infância, oferecidas em caixa com laço de fita, trazem um conjunto de textos ainda

${ }^{147}$ BARROS. Manoel. Arranjos para assobio. 4.ed., Rio de Janeiro, Record, 2002. p.11. 
não encadernados, portanto ainda não constituídos, efetivamente, como mercadoria. Sem costuras, o livro sugere estar em processo de confecção e quem alinhava páginas e sentidos é o leitor, como lhe aprouver.

Isso mostra apostar Manoel de Barros em um leitor livre, na exata medida em que sonha um homem livre. Por isso, desacorrenta-os da lógica dominante para acorrentá-los à natureza. Propõe: "para ser escravo da natureza o homem precisa de ser independente."148

Assim também livres vagueiam as personagens que povoam a obra poética do autor. Elas formam um verdadeiro "deserto de muitos eus"149. são andarilhospoetas, loucos, meninos, meninas, velhos, "bocós"150, índios, negros, vaqueiros, bêbados, aposentados, pobres. Inominadas, são pessoas consideradas desimportantes para o sistema e, por isso, descartadas dele.

Habitantes do mundo e do imundo, as personagens nominadas, muitas vezes, carregam, no nome, suas motivações, características inusitadas, suas histórias, como Mário-Captura-Sapo; seu Zezinho-margens-plácidas (fazedor de discursos patrióticos); Maria-pelego-preto (moça de 18 anos, abundante de pêlos no pente); Inácio Rubafo ("que tinha esse nome porque se alimentava de lodo" e provavelmente linha bafo ${ }^{151}$ ); Cabeludinho (cabelo comprido e olhos com remela); Antoninha-me-leva (mulher que vendia seu corpo aos boiadeiros para poder comer); Sombra-Boa (caçador, nos barrancos, de rãs entardecidas e conversa em Guató, em Português, e em Pássaro ${ }^{152}$ ); Catre-Velho ("um traste pessoal à-toa"153).

Há outras personagens cujos nomes são escritos conforme pronunciam, revelando a solidariedade do poeta com todos aqueles que se expressam pela oralidade: Polina (criança de 8 anos que não sabia falar Paulina e tinha o nariz escorrendo o tempo todo); Sabastião, louco que "preguntava": "- jacaré no seco anda?". ${ }^{154}$

\footnotetext{
${ }^{148}$ BARROS. Manoel. Concerto a céu aberto para solos de ave. 4.ed., Rio de Janeiro, Record, 2004. p.62.

${ }^{149}$ BARROS. Manoel. Arranjos para assobio. 4.ed., Rio de Janeiro, Record, 2002. p.23.

${ }^{150}$ A expressão "bocó", carregada de tom pejorativo no senso comum, assume conotação positiva na obra de Manoel de Barros.

${ }^{151}$ BARROS. Manoel. Poemas concebidos sem pecado. 4.ed., Rio de Janeiro, Record, 2005. p.57.

${ }^{152}$ BARROS, Manoel. O livro das Ignorãças. 12.ed., Rio de Janeiro, Record, 2006. p.81.

${ }^{153}$ BARROS, Manoel. Livro sobre o nada. 12.ed., Rio de Janeiro, Record, 2006. p.25.

${ }^{154}$ Idem, ibidem. p. 65.
} 
Existem, ainda, outros nomes comuns - Dona Maria (que quer comprar uma gaita, sentar-se na calçada e tocar até a vida melhorar) - e incomuns - $\underline{\text { Raphael }}$ ("Raphael não era o pintor/Nem o anjo Raphael", era "um menino do mato sem importância" ${ }^{\prime 155}$ ), que colocam à mostra a necessidade de o brasileiro romper com o imposto, dando-Ihe novas feições características da cultura brasileira. A religiosidade cristã, presente na figura de Maria ou do anjo Raphael, é posta à prova, de maneira lúdica e bem-humorada, assim como a valorização pelo que vem de fora - o pintor Raphael - assumindo ambos, Maria e Raphael, o rosto brasileiro.

Como se observa, Manoel de Barros acredita no homem simples, valoriza o homem-ninguém, a lacuna de gente, o "homem-lata" ${ }^{156}$. Desenha um ser humano que vem de "coisas que ele ajunta nos bolsos - por forma que pentes, formigas de barranco, vidrinhos de guardar moscas, selos, freios enferrujados", "coisas de nada"157 e afirma-o como o verdadeiro construtor de um novo mundo.

Seus personagens são sempre "des-heróis", para os quais ele dedica até um "anti-salmo", a fim de mostrar sua comunhão com a natureza, como se observa em:

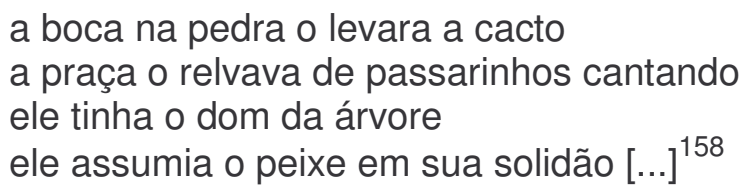

Des-heróis porque não cumprem, com heroísmo, o dever estabelecido, porque não se notabilizam por feitos guerreiros, porque não são centro das atenções - uma vez que habitam as franjas do sistema e a ele não se ajustam -, porque não despertam admiração da sociedade circundante, porque não são nobres, tampouco célebres, apesar de estarem sempre reconciliados com a natureza.

Esses des-heróis são representados, nominalmente, por Bernardo, figura que aparece de maneira recorrente em suas obras e sempre harmonizado com a natureza, como se observa em $O$ fazedor de amanhecer:

\footnotetext{
${ }^{155}$ BARROS, Manoel. Livro sobre o nada. 12.ed., Rio de Janeiro, Record, 2006. p.69.

${ }^{156}$ Referência ao poema "O homem de lata" em Gramática expositiva do chão. 5.ed., Rio de Janeiro, Record, 2006. p.23.

${ }^{157}$ BARROS. Manoel. O guardador de águas. 5.ed., Rio de Janeiro, Record, 2006. p.12.

${ }^{158}$ BARROS. Manoel. Gramática expositiva do chão. 5.ed., Rio de Janeiro, Record, 2006. p.19.
} 


\section{Bernardo}

Bernardo já estava uma árvore quando eu o conheci.

Passarinhos já construíam casas na palha do seu chapéu.

Brisas carregavam borboletas para o seu paletó

E os cachorros usavam fazer de poste suas pernas.

Quando estávamos todos acostumados com aquele

bernardo-árvore

Ele bateu asas e avoou.

Virou passarinho.

Foi para o meio do cerrado ser um arãquã.

Sempre ele dizia que o seu maior sonho era

ser um arãquã para compor o amanhecer. ${ }^{159}$

Estar árvore é adquirir o estado de sabedoria máxima. Sabemos, com Mircea Eliade, que árvore é eixo cósmico - 'axis mundi' -, ligando, portanto, Céu, terra e mundo subterrâneo. Suas raízes desbravam as profundezas; no poema, "passarinhos, borboletas, cachorros" com ela se relacionam. Ela reúne todos os elementos: terra por onde vão suas raízes, água que circula com a seiva, ar que atravessa suas folhas e fogo com o esfregar dos galhos. A árvore representa uma hierofania vegetal, ou seja, o sagrado revelado por meio do vegetal. Essa árvoreBernardo, ou Bernardo-árvore, participa de uma realidade transcendente. Não é uma árvore profana qualquer, mas se transubstancia, segundo a dialética do sagrado e do profano, já explicitada, em um elemento equivalente ao cosmos e a vida.

Estar árvore é assumir o estado iluminado de beatitude original, é integrar-se na matriz universal, adquirir estado seminal, regenerar-se, retornar à fonte de vida, revelar-se na modalidade humana em estado virtual, compor-se com o cosmos vivo na plena manifestação de suas formas e sua inesgotável regeneração.

No dizer de Mircea Eliade ${ }^{160}$,

[...] a divindade que se revela no cosmos sob forma de uma árvore é ao mesmo tempo fonte de regeneração e de 'vida sem morte', uma fonte para a qual o homem se volta porque ela justifica, a seus olhos, as esperanças que ele alimenta a respeito da sua própria imortalidade.

Como 'axis mundi', a árvore é eixo ao longo do qual circulam aqueles que passam do visível para o invisível, do profano para o sagrado. Pilar central, a árvore

\footnotetext{
${ }^{159}$ BARROS, Manoel. O fazedor de amanhecer. Rio de Janeiro, Salamandra, 2001.

${ }^{160}$ ELIADE, Mircea. Tratado de história das religiões. São Paulo, Martins Fontes, 1993. p.226.
} 
revela um caminho ascensional da terra ao céu. É símbolo da vida em permanente evolução, em ascensão, tanto que Bernardo "bateu asas e avoou", ou seja, transformou-se em pássaro, símbolo do mundo celeste.

Em Cantigas por um passarinho à toa, Bernardo, por ser o único a ter alcançado o estado de árvore, é considerado um bem, uma riqueza de importância reconhecida para a humanidade, necessitando ser preservado como Patrimônio, símbolo de imortalidade, portanto.

Esse Bernardo eu conheço de léguas.

Ele é o único ser humano

Que alcançou de ser árvore.

Por isso deve ser tombado

A Patrimônio da Humanidade. ${ }^{161}$

Em O guardador de águas, Bernardo novamente aparece como "homem percorrido de existências", aquele que faz "encurtamento de águas", "prende o silêncio com fivela", "conversa em Dialeto-rã, idioma carregado de consoantes líquidas falado por pessoas de águas ${ }^{162}$. Recorde-se que água é fonte primeira. Se ele é pessoa de águas, compõe-se como ser primordial. Em Tratado geral das grandezas do ínfimo, o poeta dedica a segunda parte a Bernardo, compondo "O livro de Bernardo":

Os meninos me letram de Bandarra.

(Bandarra é cavalo velho solto

no pasto, às moscas.)

Esse é meu estandarte.

Não tenho pensa.

Tenho só árvores ventos

passarinhos - issos.

Dentro de mim'

eu me eremito

Como os padres do ermo.

Sou aquele

que gastou a sua história

na beira de um rio.

[...]

Meu desagero

É de ser

fascinado por trastes.

${ }^{161}$ BARROS, Manoel. Cantigas por um passarinho à toa. Rio de Janeiro, Record, 2003.

${ }^{162}$ BARROS. Manoel. O guardador de águas. 5.ed., Rio de Janeiro, Record, 2006. p.10 e 20. 
$[\ldots]$

Sou livre

para o silêncio das formas

e das cores.

$[\ldots]$

Estou pousado em mim

Igual que formiga

sem rumo.

[...]

Palavras

Gosto de brincar com elas.

Tenho preguiça de ser sério.

Tenho candor

por bobagens

Quando eu crescer eu vou ficar criança. ${ }^{163}$,

Nessa passagem, Bernardo assume seu desejo de ascender à criança, de ser livre o suficiente para captar tudo o que é primeiro e inaugurar o homem no mundo, para brincar com as palavras.

No mesmo livro, aparece outra vez:

\section{Pois pois}

O Padre Antonio Vieira pregava de encostar as orelhas na boca do bárbaro.

Que para ouvir as vozes do chão

Que para ouvir a fala das águas

Que para ouvir o silêncio das pedras

Que pra ouvir o crescimento das árvores

E as origens do Ser. Pois Pois.

Bernardo da Mata nunca fez outra coisa

Que ouvir as vozes do chão

Que ouvir o perfume das cores

Que ver o silêncio das formas

E o formato dos cantos. Pois Pois.

Passei muitos anos a rabiscar, neste caderno, os

escutamentos de Bernardo.

Ele via e ouvia inexistências.

Eu penso agora que esse Bernardo tem cacoete para poeta. ${ }^{164}$

${ }^{163}$ BARROS, Manoel. Tratado geral das grandezas do ínfimo. 3.ed., Rio de Janeiro, Record, 2005. p.51-61.

${ }^{164}$ Idem, ibidem. p.47. 
Aqui, Bernardo tem dom de poeta, pois, assim como a criança, sabe ouvir as vozes da origem e do chão. Bernardo desenha-se como o novo homem - um ser cósmico - capaz de reconhecer sua interdependência da natureza e de sua origem sagrada.

Na Parte denominada "Personagem", no Livro de Pré-coisas, Manoel de Barros elege Bernardo como protagonista. Des-herói fundador do mundo, ele se sustenta à margem da civilização e compõe-se com o espaço da natureza, com o tempo primordial, constituindo-se matéria de poesia e revelando sua transcendência, sua aura sagrada:

Quando de primeiro o homem era só, Bernardo era. Veio de longe com a sua pré-história. Resíduos de um Cuiabá-garimpo, com vielas rampadas e crianças papudas, assistiram seu nascimento.[...]É muito apoderado pelo chão esse Bernardo. Seu instinto seu faro animal vão na frente.[...] Foi resolvida em língua de folha e de escama, sua voz quase inaudível. É que tem uma caverna de pássaros dentro de sua garganta escura e abortada.[...] Bernardo está pronto a poema. Passa um rio gorjeado por perto. Com as mãos aplaina as águas. Deus abrange ele. ${ }^{165}$

Além de ancestral mítico e comungado com o sagrado, como aparece na descrição acima, Bernardo tem atributo de bocó: "A mãe disse que Bernardo é bocó. Uma pessoa sem pensa"166. "Sem pensa" é uma expressão usada por Manoel de Barros, infere-se, para dizer daquele que não se submete ao pensar, ao raciocínio lógico. Em "Bocó", poema de Memórias Inventadas - A Segunda Infância, o poeta define:

Bocó é sempre alguém acrescentado de criança. Bocó é uma exceção de árvore. Bocó é um que gosta de conversar bobagens profundas com as águas. Bocó é aquele que fala sempre com o sotaque das suas origens. É sempre alguém obscuro de mosca. É alguém que constrói sua casa com pouco cisco. É um

\footnotetext{
165 BARROS, Manoel. Livro de pré-coisas: roteiro para uma excursão poética no Pantanal. 4.ed., Rio de Janeiro, Record, 2003. p.43.

${ }^{166}$ BARROS, Manoel. Livro sobre o nada. 12.ed., Rio de Janeiro, Record, 2006. p.31.
} 
que descobriu que as tardes fazem parte de haver beleza nos pássaros. Bocó é aquele que olhando para o chão enxerga um verme, sendo-o. Bocó é uma espécie de sânie com alvoradas. Foi o que o moço colheu em seus trinta e dois dicionários. E ele se estimou. ${ }^{167}$

Por harmonizar-se com as origens, Bocó, ser de exceção, tem contigüidades com criança e com poeta: "A gente inventou um truque pra fabricar brinquedos/com palavras. O truque era só virar bocó". 168 Bernardo-árvore-bocó é assemelhado, também, a andarilho, figura bastante recorrente nos textos do autor.

[...] Não tem nome nem relógio. Vagabundear é virtude atuante para ele. Nem é um idiota programado como nós. O próprio esmo é que o erra. Chega em geral com o escuro. Não salva os moradores do lugar.[...] Cedo, pela magrez dos cachorros que estão medindo o pátio, toda fazenda sabe que Bernardão chegou. "Venho do oco do mundo. Vou para o oco do mundo". É a única coisa que ele adianta. O que não adianta.[...] Anda na terra como quem desabrocha. Enquanto as águas não descem e as estradas não se mostram, Bernardo trabalha pela bóia [...] A adesão pura à natureza e a inocência nasceram com ele. Não sei se os jovens de hoje, adeptos da natureza, conseguirão restaurar dentro deles a inocência. Não sei se conseguirão matar dentro deles a centopéia do consumismo. Porque já desde nada, o grande luxo de Bernardo é ser ninguém. Por fora é um galalau, por dentro não arredou de criança. É ser que não conhece ter.Tanto que inveja não se acopla nele. ${ }^{169}$

Ao criar Bernardo, Manoel de Barros projeta um novo ser. Bernardo representa o sem-nome, sem identidade fixa, por vezes sem identidade humana, quando árvore em comunhão com a natureza. Sem relógio, não participa do mundo profano do capital, fundado no tempo linear, cronológico, repetitivo. Sua ação virtuosa não é trabalhar, como impõe ideologicamente o sistema ("o trabalho dignifica do homem"), mas vagabundear. Abandona-se ao esmo, por não sucumbir à mesmice programada da vida de consumo. Não tem atitudes heróicas de salvar pessoas. Sua origem e seu destino são o nada, o "oco do mundo". É inocente como

\footnotetext{
${ }^{167}$ BARROS, Manoel. Memórias Inventadas - A Segunda Infância. São Paulo, Planeta, 2006.

${ }^{168}$ BARROS, Manoel. Livro sobre o nada. 12.ed., Rio de Janeiro, Record, 2006. p.11.

${ }^{169}$ BARROS, Manoel. Livro de pré-coisas: roteiro para uma excursão poética no Pantanal. 4.ed., Rio de Janeiro, Record, 2003. p.47-48.
} 
criança e profundamente ajustado à natureza - o que o faz conhecer apenas o Ser e não o Ter. Representante da travessia libertária, o andarilho é aquele que se integra à natureza e a poetiza. Com Bernardo-árvore-bocó-andarilho, Manoel de Barros além de projetar um novo homem, sonha uma nova forma de estar no mundo.

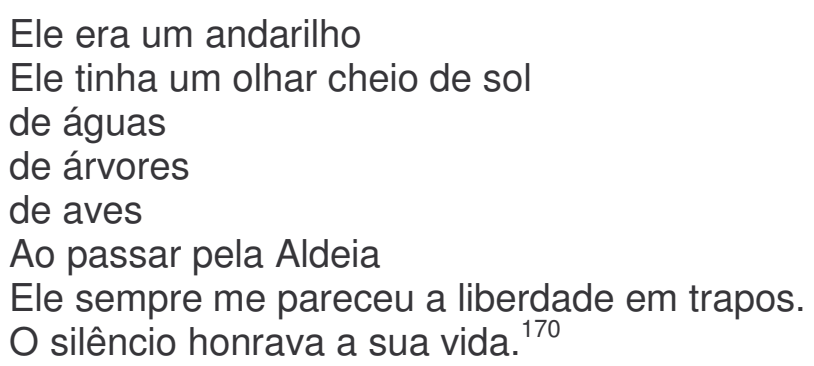

A aldeia por que passa o andarilho, evidentemente, não é regida pelo capital. Embora ganhe caráter universal, não é algo que amarra pessoas por vínculos materiais, como na sociedade mundializada (aldeia global) marcada pelo neoliberalismo.

$\mathrm{O}$ andarilho, imagem significativa e coerente com o projeto literário do poeta, pode aparecer encarnado em outras personagens, como Joaquim Sapé, e não é apenas um ser que vê, mas um ser que tem visões, prenúncios, portanto se tinge de sacralidade.

\section{Joaquim Sapé}

$[\ldots]$

Joaquim atravessa as ruelas da Aldeia como se fosse

um Príncipe

Com aqueles ornamentos de trapo.

Quando entrava na Aldeia com o saco de lata às

costas

Crianças o arrodeavam.

Um dia me falou, esse andarilho (eu era criança):

- Quando chove nos braços de uma formiga, o

horizonte diminui.[...]

Como é que esse Joaquim Sapé, que mora debaixo do chapéu, e que nem tem aparelho de medir céu, pode saber que os horizontes diminuem quando chove nos braços de uma formiga?

Se nem quase formiga tem braço![...]

Ele enxergava prenúncios! $!^{17}$

${ }^{170}$ BARROS, Manoel. Poemas Rupestres. Rio de Janeiro, Record, 2007. p.75.

${ }^{171}$ BARROS, Manoel. Tratado geral das grandezas do infimo. 3.ed., Rio de Janeiro, Record, 2005. p.37. 
Andarilho, enfim, é aquele que anda sem pressa e à toa, só conhece "as ciências que analfabetam", é um sujeito "remoto", em conjunção com a natureza e com o divino, portanto é capaz de adivinhar ${ }^{172}$.

Com a figura desse poeta-andarilho-profeta, o leitor é arremessado às origens: quando a poesia era adivinhação. Assim, Manoel de Barros vai dando contornos mais definidos a seu projeto estético enraizado no sagrado.

Para Jean Pierre Vernant ${ }^{173}$, em Mito e pensamento entre os gregos, três são os seres portadores da visão do invisível: o adivinho, o sábio e o poeta. $\mathrm{O}$ adivinho sabe do passado, do presente e do futuro. O sábio é um ser excepcional que tem o poder de ver e de fazer ver o invisível. O poeta, comunicando o escondido nas cavernas do tempo, revela, na forma do hino, da encantação e do oráculo, uma verdade essencial, camuflada por trás das aparências das coisas. Sua visão divinatória está sob o signo da deusa Mnemosyne, Memória. Deusa titã, irmã de Cronos e de Okeanós, mãe das musas, Mnemosyne preside a função poética, marcada por uma intervenção sobrenatural. O poeta, possuído pelas musas, é o "intérprete dessa divindade":

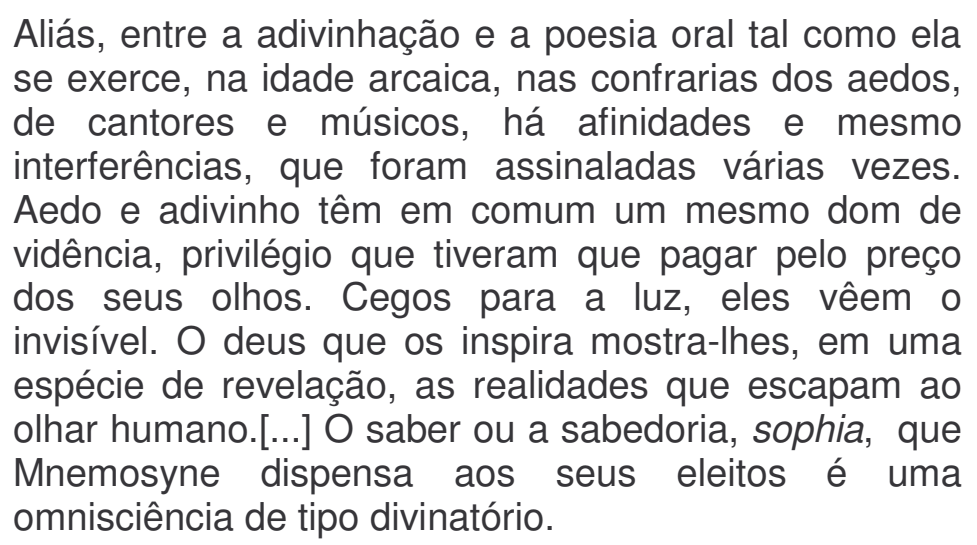

Ensina o autor ser o poeta diferente do adivinho, porque canta o que foi e não o que será. Sua atividade orienta-se para o passado, não o passado individual, mas o tempo antigo, a idade primordial, o tempo original: "O passado é parte integrante do cosmo; explorá-lo é descobrir o que se dissimula nas profundezas do ser. A

\footnotetext{
${ }^{172}$ BARROS, Manoel. Livro sobre o nada. 12.ed., Rio de Janeiro, Record, 2006. p.84-85.

${ }^{173}$ VERNANT, Jean-Pierre. Mito e pensamento entre os gregos. Rio de Janeiro, Paz e Terra, 1990. p.109.
} 
história que canta Mnemosyne é um deciframento do invisível, uma geografia do sobrenatural."174 Portanto, o poeta está em conjunção com o sagrado.

No livro Concerto a céu aberto, de Manoel de Barros, a poesia, portadora da voz silenciosa do andarilho, é devolvida às suas origens: a música, compasso de silêncio e som, de pausa e voz. Na parte denominada "Caderno de Andarilho", o leitor aprende que o canto pode ser ouvido em forma de asas. Ali, o eu poético anota, de maneira inusitada, o observado na natureza, como "Hino e limos se entendem por música. Por letra e música." ${ }^{175}$ ou "Coisa de Deus! Breve espera do rio para a passagem dos patos." 176 . Seus versos, não apenas nessa parte, mas em toda a obra, seduzem pela inauguração de um silêncio transgressor, um silêncio dissonante que paira sobre as imagens sonoras, visuais, táteis, olfativas, gustativas e converte-as ao tempo primeiro, à dimensão sagrada.

Provedor de poesia e profecia, o andarilho assume contornos de avô. Em ensaios fotográficos, lê-se:

\section{O provedor}

Andar à toa é coisa de ave.

Meu avô andava à toa.

Não prestava pra quase nunca.

Mas sabia o nome dos ventos

E todos os assobios para chamar os passarinhos.

Certas pombas tomavam ele por telhado e passavam

as tardes freqüentando o seu ombro.

Falava coisas pouco sisudas: que fora escolhido para

ser uma árvore.

Lírios o meditavam.

Meu avô era tomado por leso porque de manhã dava bom-dia aos sapos, ao sol, às águas.

Só tinha receio de amanhecer normal.

Penso que ele era provedor de poesia como as aves

e os lírios do campo. ${ }^{177}$

Sempre profetizando, promovendo ensinamentos fruto de sua vasta experiência, o avô, símbolo do velho, do abandonado, do traste, descartado do sistema de produção, é enaltecido na grandeza de sua sabedoria.

\footnotetext{
${ }^{174}$ VERNANT, Jean-Pierre. Op. Cit. p.113.

${ }^{175}$ BARROS. Manoel. Concerto a céu aberto para solos de ave. 4.ed., Rio de Janeiro, Record, 2004. p.59.

${ }^{176}$ Idem, ibidem. p. 62.

${ }^{177}$ BARROS, Manoel. Ensaios fotográficos. 5.ed., Rio de Janeiro, Record, 2005. p.51.
} 


\author{
Meu avô \\ Meu avô dava grandeza ao abandono. \\ Era com ele que vinham os ventos conversar \\ Sentava-se o velho sobre uma pedra nos fundos \\ do quintal \\ E vinham as pombas e vinham as moscas a \\ conversar. \\ Saía do fundo do quintal para dentro da \\ casa \\ E vinham os gatos a conversar com ele. \\ Tenho certeza que o meu avô enriquecia \\ a palavra abandono. \\ Ele ampliava a solidão dessa palavra. ${ }^{178}$
}

Aqui, a contrapelo do significado dicionarizado, o abandono do velho não é exclusão, é maneira sábia de estar no mundo, de reconciliar-se com a natureza, de enriquecer-se com a solidão e com o silêncio. Abandono torna-se sinônimo de compartilhamento silencioso com a natureza, com o transcendente.

Pela voz do avô, aviva-se a figura do contador de estórias, o avô poético, o narrador primeiro, forma de recusa à maquiagem interessada e interesseira imposta pela mídia contemporânea.

No Livro de pré-coisas, predominantemente prosa poética, a figura do narrador se entrelaça à do eu poético e "apresenta sua terra natal", "viaja de lancha ao encontro de seu personagem" ${ }^{179}$. Mesmo em versos, ouve-se o ressoar da voz desse velho contador, apresentando, inclusive com diálogos, acontecimentos de Corumbá.

Em vários outros poemas, há marcas dessa tradição oral, como se observa em Ensaios fotográficos: "poderia narrar muitas coisas ainda que pude ver do ponto de vista de uma borboleta"; "Difícil fotografar o silêncio. Entretanto tentei. Eu conto: $[\ldots]^{\prime 180}$. Isso resgata, também, um tempo primeiro em que a poesia se fazia como narrativa heróica dos povos.

Aqui, quem narra é o avô, portador da mais vasta sabedoria, porta-voz do projeto estético do autor, como se nota:

\footnotetext{
${ }^{178}$ BARROS, Manoel. O fazedor de amanhecer. Rio de Janeiro, Salamandra, 2001.

${ }^{179}$ BARROS, Manoel. Livro de pré-coisas: roteiro para uma excursão poética no Pantanal. 4.ed., Rio de Janeiro, Record, 2003.

${ }^{180}$ BARROS, Manoel. Ensaios fotográficos. 5.ed., Rio de Janeiro, Record, 2005. p.59 e 110.
} 
A voz de meu avô arfa. Estava com um livro debaixo dos olhos. Vô! o livro está de cabeça pra baixo. Estou deslendo. ${ }^{181}$

"Desler" é a palavra-chave para compreender a proposta poética de Manoel de Barros. "Desler" significa desaprender. Pela voz do avô, Manoel de Barros vai destecendo nossa aprendizagem, vai desfolhando toda a cultura humana, vai decompondo liricamente, vai decantando a história humana, a ponto de atingir a essência dos homens, das coisas, da linguagem, até chegar ao estado 'coisal', (coisa não no sentido de mercadoria): o inominado. Para ele, o homem precisa tornar-se coisal para que the aflore um entendimento sobrecomum, sobrenatural, distinto do ordinário. Dessa maneira, ele vai coisificando o homem para sacralizá-lo. Coisificado, ele é capaz de alcançar estado de árvore, transbordar sabedoria, como a criança, o andarilho e o poeta, reinventar-se em estado inaugural, adquirir consciência e empoemar o verbo.

\footnotetext{
No que o homem se torne coisal - corrompem-se nele os veios comuns do entendimento.

Um subtexto se aloja.

Instala-se uma agramaticalidade quase insana, que

Empoema o sentido das palavras,

Aflora uma linguagem de defloramentos, um inauguramento de falas.

Coisa tão velha como andar a pé.

Esses vareios do dizer. ${ }^{182}$
}

Esse entendimento sobrecomum decorrente de o homem tornar-se coisa torna-o capaz de expressar o inominado, de inaugurar falas.

[...]Porém, vendo o Homem

que as moscas não davam conta de iluminar o

silêncio das coisas anônimas -

passaram essa tarefa para os poetas. ${ }^{183}$

Ao inaugurar falas para traduzir o inominado, aproxima-se das crianças: "as coisas que não tem nome são mais pronunciadas por crianças" ${ }^{184}$. Assim, a voz do

\footnotetext{
${ }^{181}$ BARROS, Manoel. Livro sobre o nada. 12.ed., Rio de Janeiro, Record, 2006. p.30.

${ }^{182}$ BARROS. Manoel. O guardador de águas. 5.ed., Rio de Janeiro, Record, 2006. p.62.

${ }^{183}$ BARROS. Manoel. Concerto a céu aberto para solos de ave. 4.ed., Rio de Janeiro, Record, 2004. p.49.

${ }^{184}$ BARROS, Manoel. O livro das ignorãças. 12.ed., Rio de Janeiro, Record, 2006. p.13.
} 
poeta e a da criança alinhavam-se no exercício de "fazer nascimentos". Ambos se aproximam do delírio do verbo - marca de seu projeto estético.

O autor valoriza, assim, tudo o que vem da infância - do mundo e do ser: a linguagem, o pensamento mágico, a forma de estar no mundo. Ensina-nos, em "Pelada de barranco", publicado em Memórias Inventadas - A Segunda Infância: "Nada havia de mais prestante em nós senão a infância. O mundo começava ali" 185 . Aliás, o ensinamento do avô é que "os andarilhos, as crianças e os passarinhos têm o dom de ser poesia"186.

O homem só pode chegar à liberdade, a essa grandeza infantil, desconhecendo, desaprendendo, desfiando e desafiando os valores da civilização, apreendendo a natureza e a palavra em estado primeiro - idéia que sintoniza o poeta com as grandes vozes de seu tempo, como Guimarães Rosa, Clarice Lispector, João Cabral de Melo Neto, entre outros:

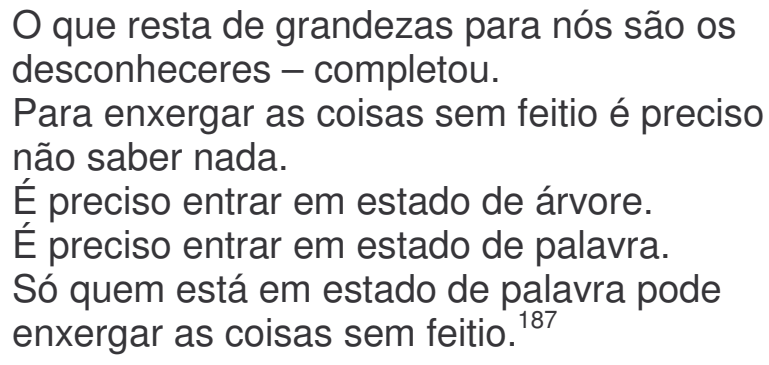

A palavra em estado primeiro é chamada de "des-palavra", porque ela se associa ao canto, segundo o poeta, refere-se mais ao canto do pássaro do que ao do ser humano.

Agora só espero a despalavra: a palavra nascida para o canto - desde os pássaros.

A palavra sem pronúncia, ágrafa.

Quero o som que ainda não deu liga.

Quero o som gotejante das violas de cocho

A palavra que tenha um aroma ainda cego.

Até antes do murmúrio.

Que fosse nem um risco de voz.

Que só mostrasse a cintilância dos escuros.

A palavra incapaz de ocupar o lugar de uma

Imagem.

$\mathrm{O}$ antesmente verbal: a despalavra mesmo. ${ }^{188}$

\footnotetext{
${ }^{185}$ BARROS, Manoel. Memórias Inventadas - A Segunda Infância. São Paulo, Planeta, 2006.

${ }^{186}$ BARROS, Manoel. Memórias Inventadas - A Infância. São Paulo, Planeta, 2006.

${ }^{187}$ BARROS, Manoel. Retrato do artista quando coisa. 4.ed., Rio de Janeiro, Record, 2004. p.35.

${ }^{188}$ Idem, ibidem. p.53.
} 
O antesmente da palavra é o que se anuncia no Livro de pré-coisas, na parte denominada "Ponto de Partida", na qual o título "Anúncio" sugere, em jogo ambíguo de palavras, o diálogo crítico com os anúncios publicitários. Concebida como Anunciação, a palavra "Anúncio" é deslocada de seu sentido prosaico e denotativo e revestida de uma aura sagrada, por meio da qual se entrevê, milagrosamente, o invisível, o "antesmente verbal": "manchas", "nódoas de imagens", "festejos de linguagem", definindo, assim, as pré-coisas inspiradoras da arte de transfazer de Manoel de Barros.

Com essa linguagem do antesmente da palavra, o leitor vai experimentando os desacontecimentos:

As coisas que acontecem aqui, acontecem paradas. Acontecem porque não foram movidas. Ou então, melhor dizendo: desacontecem. ${ }^{189}$

Nesse avanço gradativo à origem da linguagem, vai des-aprendendo o leitor valores impostos pelo capitalismo e por todo o paradigma que sustenta a razão ocidental, alargando a visão e des-cobrindo possibilidades de transcender, de "desorbitar pela imaginação", por meio da palavra criadora de uma nova realidade com a qual se faz o contar poético andarilho do poeta brasileiro:

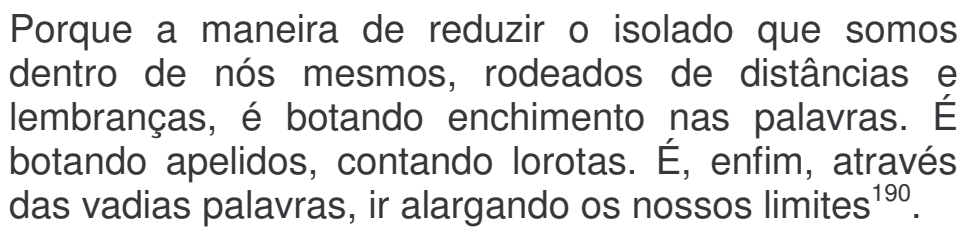

No movimento do trem, o leitor vai deslendo sua história. Da janela, vai percebendo o afastar da velha e inimiga missão de dominar, subjugar e conquistar a natureza. No trepidar dos trilhos, ele observa estar se distanciando da ideologia do progresso e do consumo e do ponto nevrálgico em que se fundou a razão ocidental e dessacralizou a vida humana. Ao ouvir os sussurros das vozes ancestrais que penetram e passam a ecoar no interior do trem, ele vai se recompondo com o tempo no qual o homem comungava com a natureza. Ao ter as visões das paisagens

\footnotetext{
189 BARROS, Manoel. Livro de pré-coisas: roteiro para uma excursão poética no Pantanal. 4.ed., Rio de Janeiro, Record, 2003. p.31.

${ }^{190}$ Idem, ibidem. p.33.
} 
primordiais pela abertura das janelas, mais do que resíduo, mais do que moldura, a natureza nele se consagra.

Há um cio vegetal na voz do artista.

Ele vai ter que envesgar seu idioma ao ponto de alcançar o murmúrio das águas nas folhas das árvores. Não terá mais o condão de refletir sobre as coisas. Mas terá o condão de sê-las.

Não terá mais idéias: terá chuvas, tardes, ventos, passarinhos... ${ }^{191}$

No dobrar das palavras, segue o leitor um itinerário divino, avesso ao civilizado, capaz de recompô-lo com seu momento animista primeiro:

Sente-se pois então que árvores, bichos e pessoas tem natureza assumida igual. O homem no longe, alongado quase, e suas referências vegetais e animais. Todos se fundem na mesma natureza intacta. Sem as químicas do civilizado. O velho quase-animismo. ${ }^{192}$

Pelo entortar do verbo, o leitor encontra-se com o mito, o narrar primeiro do homem:

Era só água e sol de primeiro este recanto. Meninos cangavam sapos. Brincavam de primo com prima. [...] Não havia instrumento musical. Os homens tocavam gado. As coisas ainda inominadas. Como no começo dos tempos.

Logo se fez a piranha. Em seguida os domingos e feriados. Depois os cuiabanos e os beira-corgos. Por fim o cavalo e o anta batizado.[...] O homem havia sido posto ali nos inícios para campear e hortar.[...] Daí que campear se fez preferência por ser atividade livre e andeja. Enquanto que hortar prendia o ente no cabo da enxada.[...] O que não era bom. ${ }^{193}$

Campeando paisagens, segue o leitor sua peregrinação até entrever o amanhecer de uma nova era, em que a criatividade, a espontaneidade, "o criançamento" ganham brilho. Desponta no horizonte da palavra um novo homem,

\footnotetext{
${ }^{191}$ BARROS, Manoel. Retrato do artista quando coisa. 4.ed., Rio de Janeiro, Record, 2004. p.17.

${ }^{192}$ BARROS, Manoel. Livro de pré-coisas: roteiro para uma excursão poética no Pantanal. 4.ed., Rio de Janeiro, Record, 2003. p.34.

${ }^{193}$ Idem, ibidem. p.37-38.
} 
reconciliado com sua natureza interior, consciente de sua interdependência com a natureza exterior e da necessidade de construir laços um tanto mais luminosos e afetivos com os outros seres iguais. Assim vai entrevendo a aurora de uma nova ordem.

A força poética de Manoel de Barros oferece-nos um novo arranjo de possibilidades inventivas e transformadoras capaz de restaurar o homem na sua origem: na sua essência e na sua infância - por excelência, um percurso sagrado de ascensão.

\section{Ascensão}

Depois que iniciei minha ascensão para a infância, Foi que vi como o adulto é sensato!

Pois como não tomar banho nu no rio entre pássaros?

Como não furar lona de circo para ver os palhaços?

Como não ascender ainda mais até na ausência da voz?

(Ausência da voz é infantia, com t, em latim.)

Pois como não ascender até a ausência da voz Lá onde a gente pode ver o próprio feto do verbo ainda em movimento.

Aonde a gente pode enxergar o feto dos nomes Ainda sem penugens.

Por que não voltar a apalpar as primeiras formas da pedra. A escutar os primeiros pios dos pássaros. A ver as primeiras cores do amanhecer.

Como não voltar para onde a invenção está virgem? Por que não ascender de volta para o tartamudo! ${ }^{194}$

É para essa direção celestial que nos encaminha o poeta brasileiro. Seu projeto não pretende uma volta linear e repetitiva ao primitivo, mas engendra um movimento em espiral, a partir do qual se torna possível não só ascender à criança, mas também a pássaro, como ele mesmo sugere: "Eu queria crescer pra passarinho..."195

Como criança, é possível exercitar o amor por coisas insignificantes, ter deslumbramentos com o sotaque das lesmas, explorar os mistérios do mundo, ser

\footnotetext{
${ }^{194}$ BARROS, Manoel. Tratado geral das grandezas do infimo. 3.ed., Rio de Janeiro, Record, 2005. p.41.

${ }^{195}$ BARROS, Manoel. Livro sobre o nada. 12.ed., Rio de Janeiro, Record, 2006. p.30.
} 
vidente e "apertar parafuso no vento"196, enxergar como os pássaros, inventar poesia com "peraltagens e despropósitos"197, brincar livremente com o inominado, comporse com o princípio da vida, com tudo que inaugura o mundo.

Como passarinho, é possível contrair visão das fontes e enxergar as coisas inominadas, voar livremente e sem limites, entrelaçar-se com o infinito e não temer o horizonte, sonhar e fazer o amanhecer, não ter medo de entregar seu canto e, com olhos livres e feito andarilho, errar pelo universo.

Essa composição de criança e pássaro dá nome à primeira parte do livro Compêndio para uso dos pássaros ${ }^{198}$, denominada "De meninos e pássaros" - que será objeto de nossa análise comparativa posteriormente.

Como pássaro e como criança, é possível perambular pelo desconhecido e pelo inominado, resgatando, assim, a qualidade de ser errante, a grandeza da ignorância.

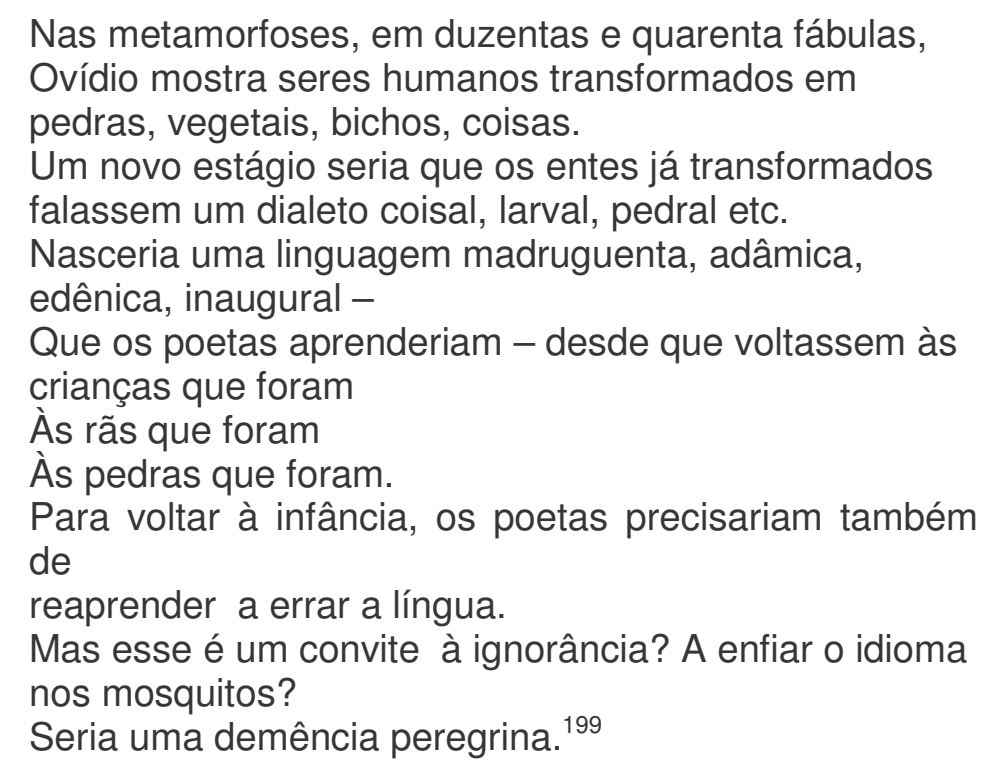

Uma língua-menina, livre, adâmica é a proposta desse poeta contemporâneo que canta os primórdios. Uma língua que transcende o padrão e abre múltiplas possibilidades, uma língua andarilha, capaz de perambular pelas imagens em um tempo mítico chamado "quando". É a evocação que se faz:

\footnotetext{
${ }^{196}$ BARROS, Manoel. Tratado geral das grandezas do ínfimo. 3.ed., Rio de Janeiro, Record, 2005. p.25.

${ }^{197}$ Referência ao texto "O menino que carregava água na peneira", do livro Exercícios de ser criança. Rio de Janeiro, Salamandra, 1999.

${ }^{198}$ BARROS, Manoel. Compêndio para uso dos pássaros. Rio de Janeiro, Record, 1999.

${ }^{199}$ BARROS. Manoel. O guardador de águas. 5.ed., Rio de Janeiro, Record, 2006. p.64.
} 
Eu não amava que botassem data na minha existência. A gente usava mais era encher o tempo.Nossa data maior era o quando. O quando mandava em nós.A gente era 0 que quisesse ser só usando esse advérbio.[...] Nesse tempo a gente era quando crianças. Quem é quando criança a natureza nos mistura com as suas árvores, com as suas águas, com o olho azul do céu. Por tudo isso que eu não gostasse de botar data na existência. Por que o tempo não anda pra trás. Ele só andasse pra trás botando a palavra quando de suporte. ${ }^{200}$

Esse tempo "quando" engendra um mundo sem conceitos, mas fecundo de imagens, com as quais a criança empoema a vida e o poeta engravida o verso por puro afeto:

\footnotetext{
Hoje atingi o reino das imagens, o reino da despalavra

Daqui vem que todas as coisas podem ter qualidades humanas.

Daqui vem que todas as coisas podem ter qualidades de pássaros.

Daqui vem que todas as pedras podem ter qualidades de sapo.

Daqui vem que todos os poetas podem ter qualidades de árvore.

Daqui vem que os poetas podem arborizar os pássaros.

Daqui vem que todos os poetas podem humanizar as águas.

Daqui vem que todos os poetas devem aumentar o mundo com suas metáforas.

Que os poetas podem ser pré-coisas, pré-vermes, podem ser pré-musgos.

Daqui vem que os poetas podem compreender o mundo sem conceitos.

Que os poetas podem refazer o mundo por imagens, por eflúvios, por afetos. ${ }^{201}$
}

Em seu brincar poético, Manoel de Barros $^{202}$ propõe a palavra indisciplinada, errante, corpórea, capaz de atingir mais os órgãos do sentir do que os do pensar:

\footnotetext{
${ }^{200}$ BARROS, Manoel. Memórias Inventadas - A Segunda Infância. São Paulo, Planeta, 2006.

${ }^{201}$ BARROS, Manoel. Ensaios fotográficos. 5.ed., Rio de Janeiro, Record, 2005. p.23.

${ }^{202}$ BARROS, Manoel. Memórias Inventadas - A Infância. São Paulo, Planeta, 2006.
} 
Aprendi nessas férias a brincar de palavras mais do que a trabalhar com elas. Comecei a não gostar de palavra engavetada. Aquela que não pode mudar de lugar. Aprendi a gostar mais das palavras pelo que elas entoam do que pelo que elas informam.

Assim também lúdicas são as ilustrações da maioria das obras, feitas por Martha Barros, filha do poeta, que brilhantemente reproduz o desenho infantil primeiro, em garatujas, ora sugerindo visões, sons, paisagens, perfumes, ora criando um verdadeiro mundo, um 'genesis' visual, como na capa de Retrato do Artista quando coisa (ilustração escolhida para a abertura deste capítulo).

Manoel de Barros e Martha Barros propõem novas perspectivas oriundas da mente intuitiva, do pensamento concreto, da natureza primitiva e infantil. Buscam menos o conhecimento racional e mais o intuitivo. Buscam menos a racionalidade e mais a sensibilidade de filigrana da qual são senhores absolutos.

Revelam um olhar-criança, capaz de descobrir o mundo, comungando com as coisas, com a natureza e não refletindo sobre idéias, como faz o adulto, preocupado com a lógica, com conceitos e classificações. Se característica do adulto é comparar, a da criança é comungar. Comungar é ato sagrado; comparar é ato profano. Assim, a criança mostra-se mais aberta ao sagrado do que o adulto.

Cresci brincando no chão, entre formigas. De uma infância livre e sem comparamentos. Eu tinha mais comunhão com as coisas do que comparação. Porque se a gente fala a partir de ser criança, a gente faz comunhão [...] Então eu trago das minhas raízes crianceiras a visão comungante e oblíqua das coisas. ${ }^{203}$

Daí o assombro provocado por essa consagrada poesia brasileira, ao suspender a percepção ordinária do mundo e despertar os sentidos para uma visão extraordinária das coisas. Como "indivíduo que enxerga semente germinar e engole o céu"204, Manoel de Barros põe à revelia os sentidos ordinários da palavra, acordando seus sentidos extraordinários. Mostra-se arqueólogo do verbo, tendo como missão escovar palavras e buscar nelas os clamores antigos escondidos em

\footnotetext{
${ }^{203}$ BARROS, Manoel. Memórias Inventadas - A Infância. São Paulo, Planeta, 2006.

${ }^{204}$ Uma das acepções de poeta, retirada do Glossário proposto em Arranjos para assobio (BARROS, Manoel. Arranjos para assobio. 4.ed., Rio de Janeiro, Record, 2002. p.45).
} 
suas conchas ${ }^{205}$. E isso ele afirma fazer ${ }^{206}$, ao revelar que não se inspira para escrever, mas tem loucura pela palavra. Busca no dicionário a existência ancestral dela e aí descobre os motivos para o poema.

Ouvem-se, em seu prelúdio poético e sagrado, os cantos que emanam do mais fundo da terra, capazes de inaugurar uma dança silenciosa na alma dos leitores e, assim, eles se surpreendem amanhecendo.

No fim do percurso realizado com Manoel de Barros, pisamos o chão. No texto "Ver", de Memórias Inventadas - A Infância, o narrador dirige seu olhar para os animais que rastejam, como lesmas, lagartixas, confessando que esses, sim, sabem ouvir os cantos do chão:

Confesso, aliás, que eu gostava muito, a esse tempo, de todos os seres que andavam a esfregar as barrigas no chão. Lagartixas fossem muito principais do que as lesmas nesse ponto. Eram esses pequenos seres que viviam ao gosto do chão que me davam fascínio. Eu não via nenhum espetáculo mais edificante do que pertencer do chão. Para mim esses pequenos seres tinham o privilégio de ouvir as fontes da Terra. ${ }^{207}$

Também os vegetais que brotam das fontes da Terra ganham valência sacralizada:

Só as coisas rasteiras me celestam.

[...]

As violetas me imensam. ${ }^{208}$

Tanto a matéria de sua poesia quanto a forma como ela se constrói envergam para o chão. Em Matéria de Poesia, ao enumerar o que pode ser feito a favor da língua, canta o eu-poético: "deixar os substantivos passarem anos no esterco, deitados de barriga, até que eles possam carrear para o poema um gosto de chão"209. Ainda em Matéria de Poesia, pesca-se na fala de Gidian (ou Gedeão): "o chão tem altares e lagartos" ${ }^{210}$. Constata-se, na elaboração expressiva de Manoel

\footnotetext{
${ }^{205}$ Conforme evoca em Memórias Inventadas - A infância (BARROS, Manoel. Memórias Inventadas - A Infância. São Paulo, Planeta, 2006).

${ }^{206}$ Referência feita em entrevista publicada no site www.cronopios.com.br. Acesso em 15-12-06.

${ }^{207}$ BARROS, Manoel. Memórias Inventadas - A Infância. São Paulo, Planeta, 2006.

${ }^{208}$ BARROS, Manoel. Livro sobre o nada. 12.ed., Rio de Janeiro, Record, 2006. p.41.

${ }^{209}$ BARROS, Manoel. Matéria de poesia. 5.ed., Rio de Janeiro, Record, 2005. p.18.

${ }^{210}$ Idem, ibidem. p. 31 .
} 
de Barros, pela associação inusitada dos substantivos altares e lagartos, a combinação que acredita existir entre o chão e o sagrado.

Para o poeta, "o chão é um ensino"211. Em sua obra, ele, de fato, desenha, representativamente, o chão brasileiro, naquilo que possui de mais sagrado: a natureza vegetal, animal, mineral. Sabiás, lagartixas, vagalumes, minhocas, caramujos, gavião, lambaris, garças, lagartos curimpãpãs, periquitos, pardais, corós, urubus, beija-flores, tartarugas, besouros, araras, calangos, sucuris, jacarés, musgos, violetas, bananeiras, gerânios - espécies da flora, da fauna povoam o território poético desse grande escritor e nos ensinam do chão brasileiro. Sua poesia nos faz enxergar nossa nação tanto em sua geografia física quanto em sua geografia humana.

Suas personagens, nominadas e inominadas, são meninos, meninas, velhos, índios, negros, vaqueiros, bêbados, aposentados, pobres, nacionalistas como Zezinho-margens plácidas, crianças com remela nos olhos, nariz escorrendo, como Cabeludinho e Polina, prostitutas, entre outros que compõem nossa paisagem humana.

Afirma Milton Santos ${ }^{212}$ : "é melhor fazer a nação por intermédio do seu território, porque nele tudo o que é vida está representado". Se território pode ser definido como o chão aliado à população, é dele que nos fala, poeticamente, Manoel de Barros, na tentativa de nos arregalar os olhos para nossa própria identidade.

Bernardo sintetiza essa ecologia humana e natural e nos aponta caminhos possíveis de transformação. Sem-nome, sem reconhecimento, deslocado do centro das atenções, distante do mundo profano e repetitivo do capital, Bernardo configurase como o representante de nossa travessia libertária. Figura errante, abandonada ao esmo, não se enverga à mesmice da vida de consumo. Inocente, meio-poeta, meio-bocó, com marcas de traste e feição coisal, resume as grandezas de nosso íntimo. Misto de criança e velho, comungado com a natureza, é capaz de ouvir as vozes da origem - atribuindo, por isso, mais valor ao Ser do que ao Ter. Bernardo devolve-nos o sentimento de pertencer àquilo que nos pertence, isto é, nossa identidade, nossa cultura e nosso modo de estar no mundo. Por ter alcançado

\footnotetext{
${ }^{211}$ BARROS. Manoel. Arranjos para assobio. 4.ed., Rio de Janeiro, Record, 2002. p.47.

${ }^{212}$ SANTOS, Milton. Por uma outra globalização: do pensamento único à consciência universal. 7.ed., Rio de Janeiro, Record, 2001. p.87.
} 
estado de árvore, Bernardo nos ensina quem somos, ensina-nos de nosso chão, conforme registra o verbete em Arranjos pra assobio:

\author{
Árvore, s.f. \\ Gente que despetala \\ Possessão de insetos \\ Aquilo que ensina de chão \\ Diz-se de alguém com resina e falenas \\ Algumas pessoas em quem o desejo \\ é capaz de irromper sobre o lábio \\ como se fosse raiz de seu canto ${ }^{213}$
}

Manoel de Barros ${ }^{214}$, em seu criar poético, mostra-nos que "no achamento do chão também foram descobertas as origens do vôo". Ao encontrarmos as marcas que nos singularizam, podemos sedimentar nosso desejo de voar e ir ao encalço de nossos sonhos. Feito pássaro, podemos procurar novos horizontes, abrindo fendas para mudanças de curso. Enlaçando o passado adormecido em nosso chão, podemos nos lançar ao futuro e ao encontro com o outro, rompendo fronteiras, impulsionados pelo desejo de fazer aproximações comunitárias. Esse é nosso sonho neste trajeto.

Despropositadamente, ensina o poeta mato-grossense:

Das vilezas do chão

Vêm-lhe as palavras

Chega têm ouro

Até. Chega libélulas. ${ }^{215}$

As palavras vêm das vilezas do chão e, por comporem uma língua comum, a Língua Portuguesa, favorecem a aproximação das duas culturas: brasileira e africana.

A poesia de Manoel de Barros, apesar de e por causa de seu despropósito e peraltagem, potencializa nossa ascensão. Se sua voz revela em verso que imagina ter herdado esse olhar rasteiro, para baixo, em razão de "ancestralidades machucadas"216 , eis a possibilidade de cicatrizar essa ferida e fecundar renovação.

\footnotetext{
${ }^{213}$ BARROS. Manoel. Arranjos para assobio. 4.ed., Rio de Janeiro, Record, 2002. p.47.

${ }^{214}$ BARROS. Manoel. O guardador de águas. 5.ed., Rio de Janeiro, Record, 2006. p.11.

${ }^{215}$ Idem, ibidem. p.31.

${ }^{216}$ BARROS, Manoel. Retrato do artista quando coisa. 4.ed., Rio de Janeiro, Record, 2004. p.27.
} 
Muitos defendem que o labor poético suspende a práxis. Entretanto, na esteira de Alfredo Bosi ${ }^{217}$, trata-se de uma suspensão momentânea e aparente, pois, ao projetar, na consciência do leitor, imagens do mundo e do homem mais significativas do que as forjadas pelas ideologias, o poema desperta o desejo de uma existência outra e, ao aproximar sujeito de objeto e sujeito de sujeito, acaba por suspender a lacuna que os distancia. Por isso, a transfiguração literária de Manoel de Barros é práxis: toca no corpo, sulca no coração e se inscreve na consciência.

Não são todos os trabalhos que humanizam, nem toda poesia torna o homem mais humano, especialmente as mais servis, como a utilitária. Entretanto, a cosmogonia poética de Manoel de Barros rompe com a percepção míope do homem atual e, escovando palavras e escavando a memória, alça vôo, conduzindo às infindáveis aberturas para o futuro.

Esse poeta maior comunga com os deslimites do verbo e do silêncio em vadiagem poética. Sua obra tem o poder de fecundar e renovar a vida e o homem. São rudimentos, liames primordiais, rascunhos, embriões, sêmens que inauguram um mundo outro no qual o homem se irriga de natureza e, como dádiva, aprende a ver o acontecimento quando ele desacontece. Seus versos florescem pontes entre o rio-dentro e o rio-fora, inserindo no leitor um 'olho de descobrir', levando-o a perceber o imperceptível, o transcendente.

Podemos afirmar que esse poeta das pequenas coisas é um iniciado e inicia o leitor, abrindo-Ihe a possibilidade milagrosa de exercer seu ato de criação. PermiteIhe o instante sagrado de recriar o mundo por intermédio da palavra, assim como ele mesmo, conscientemente, recria.

Em O livro das ignorãnças, constatamos sua "didática da invenção" (Parte 1). Ele cria o livro como se criasse um mundo. Registra o Dia um, o Segundo dia e o Terceiro dia (Parte 2), até que nasce o "Mundo pequeno"(Parte 3). Dialoga enviesado com a criação bíblica, visto que, na Parte 1, propõe uma desaprendizagem para chegar aos princípios, enunciando: "no descomeço era o verbo" ${ }^{218}$. O início da parte 2 é precedido por uma "explicação desnecessária", na qual deixa viva a imagem do dilúvio: "na enchente de 22, a maior de todas as enchentes do Pantanal, canoeiro Apuleio vogou três dias e três noites por cima das

\footnotetext{
${ }^{217}$ BOSI, Alfredo. O ser e o tempo da poesia. 6.ed., São Paulo, Cia das Letras, 2000. p.227.

${ }^{218}$ BARROS, Manoel. O livro das ignorãças. 12.ed., Rio de Janeiro, Record, 2006. p.15.
} 
águas, sem comer nem dormir - e teve um delírio frásico"219. Na Parte 3, registra um mito dos índios guatós:

O mundo não foi feito em alfabeto.Senão que
primeiro em água e luz. Depois árvore. Depois
lagartixas. Apareceu um homem na beira do rio.
Apareceu uma ave na beira do rio. Apareceu a
concha . E o mar estava na concha. A pedra foi
descoberta por um índio. O índio fez fósforo da
pedra e inventou o fogo pra gente fazer bóia. Um
menino escutava o verme de uma planta, que era
pardo. Sonhava-se muito com pererecas e com
mulheres.As moscas davam flor em março. Depois
encontramos com a alma da chuva que vinha do lado
da Bolívia - e demos no pé.
(Rogaciano era índio guató e me contou essa
cosmologia.)

Esse poeta-andarilho, que erra pela língua e a tem como permanente iniciação, elege um leitor, também andarilho, dotado de desejo suficiente para realizar sua travessia imaginária, seu ritual de passagem. Várias são as provas: ler com o corpo, perceber pelo pensamento mágico - tarefas que desacostumam a passividade do leitor. Escolher sentidos, compor o mosaico ilógico, experimentar a língua de maneira lúdica, inusitada, ouvir a voz das coisas, da natureza, da criança, valorizar o insignificante, arregalar os olhos para o divino, desaprender - são exercícios bem pouco exigidos no mundo contemporâneo, de forma que provocam estranhamento - o que faz da leitura um percurso dificultoso e, portanto, iniciático.

A obra de Manoel de Barros é um verdadeiro útero poético, dentro do qual o leitor mergulha e sai qualitativamente diferente. Ali todas as forças se unem para promover a passagem de um modo de ser a outro.

Se como ensina o fotógrafo-poeta, "a importância de uma coisa há que ser medida pelo encantamento que a coisa produza em nós", de forma que "um passarinho nas mãos de uma criança é mais importante para ela do que a Cordilheira dos Andes"221, a poesia deste consagrado brasileiro vale nossa própria vida. É com ela que alargamos nossa visão, revertemos valores para construirmos um mundo um tanto mais humano, valorizando coisas desprezíveis, seres

\footnotetext{
${ }^{219}$ BARROS, Manoel. O livro das ignorãças. 12.ed., Rio de Janeiro, Record, 2006. p.31.

${ }^{220}$ BARROS, Manoel. O livro das ignorãças. 12. ed., Rio de Janeiro, Record, 2006. p.95.

${ }^{221}$ BARROS, Manoel. Memórias Inventadas - A Segunda Infância. São Paulo, Planeta, 2006.
} 
abandonados, por meio da recuperação do tempo primeiro e da entrevisão do sagrado.

O Cosmos de Manoel de Barros é tão vivo e tão imenso que o leitor se sente pequeno e, na sua insignificância, encontra a máxima grandeza de ser.

Se é em estado de graça que o leitor se percebe ao ser invadido pela paisagem poética desse autor, é porque este tem um olhar religioso, furado de natureza e de nascimentos. Segundo Mircea Eliade ${ }^{222}$, "para o homem religioso, a Natureza nunca é exclusivamente natural: está sempre carregada de um valor religioso". Isso ocorre porque o Cosmos é criação, ele existe antes de tudo e foi obra dos deuses, portanto está impregnado de transcendência e de sacralidade. Assim, o sobrenatural associa-se ao natural, ou seja, a natureza revela sempre algo mais que a transcende. Manoel de Barros tem sensibilidade aguçada para nos fazer ver, no natural, o sobrenatural.

Opera com elementos ligados tanto ao mundo celeste quanto ao mundo terrestre. Revela movimentos, ritmos, sons, aromas, toda a vitalidade e a fecundidade desses reinos. Mostra Mircea Eliade ${ }^{223}$ :

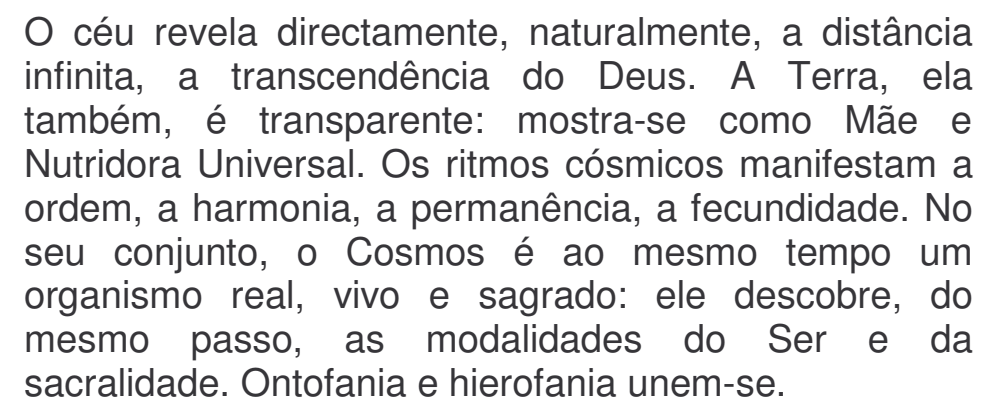

O poeta do céu e do chão enumera uma infinidade de pássaros da fauna brasileira, além de outras imagens que revelam o mundo celeste e a ele se aliam, como nuvens, ventos, estrelas, sol, lua e assim por diante; reúne, também, uma multiplicidade de animais rastejantes, que sabem do chão, como tartarugas, lesmas, cobras, entre outros - deixando o leitor em estado de coisa, fazendo-o participar da condição divina ao penetrar nesse santuário poético. Essa sensação do infinito invade a alma do leitor, elevando-a a estado de graça, descobrindo tanto a incomensurabilidade divina quanto sua própria situação no Cosmos.

\footnotetext{
${ }^{222}$ ELIADE, Mircea. O sagrado e o profano: a essência das religiões. Trad. Rogério Fernandes. Lisboa, Edição Livros do Brasil.s.d. p.127.

${ }^{223}$ Idem, ibidem. p. 127.
} 
Mesmo quando a vida religiosa já não é mais dominada por deuses a serem cultuados, as regiões siderais e terrestres guardam, de maneira camuflada, esse simbolismo. Dessa forma, tanto aquilo que está no alto quanto o que brota do chão continuam a revelar o transcendente e essa dimensão sagrada da existência invade a alma do leitor ao recriar o mundo inventado por Manoel de Barros. Essa sacralidade é atribuída pelo poeta à natureza e ele mostra-se consciente disso, também, porque seleciona palavras do campo semântico religioso para compor suas entrevisões poéticas:

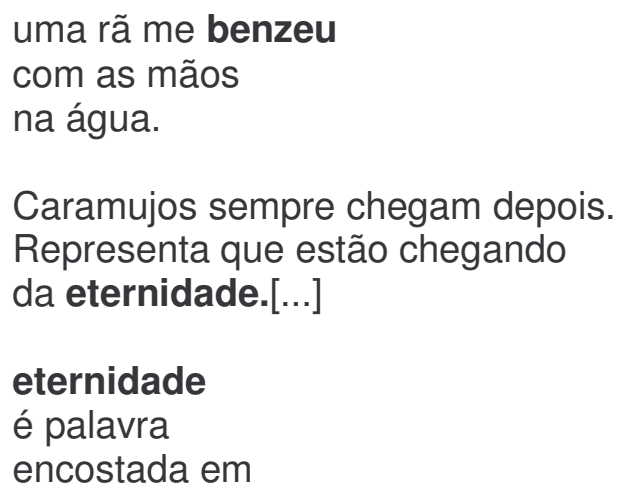

Sou beato de águas

De pedras

e de aves. ${ }^{224}$ (grifos nossos)

É na vida ordinária que o poeta busca diálogo com o extra-ordinário, para o qual nos arregala os olhos. Ele é capaz de ultrapassar o conhecimento instituído para pregar o valor da leitura de mundo, capaz de tocar, misteriosamente, o homem. Com ele, as imagens profanas ganham aura sagrada. A árvore enunciada ultrapassa o seu contorno profano e hierofaniza-se, manifestando o sagrado como se lê em:

\section{Árvore}

${ }^{224}$ BARROS, Manoel. Tratado geral das grandezas do ínfimo. 3.ed., Rio de Janeiro, Record, 2005. p.52. 


\begin{abstract}
Um passarinho pediu a meu irmão para ser árvore.
Meu irmão aceitou de ser a árvore daquele passarinho.

No estágio de ser essa árvore, meu irmão aprendeu de

Sol, de céu e de lua mais do que na escola.

No estágio de ser árvore meu irmão aprendeu para santo

Mais do que os padres lhes ensinavam no internato.

Aprendeu com a natureza o perfume de Deus.

Seu olho no estágio de ser árvore aprendeu melhor o azul.

E descobriu que uma casca vazia de cigarra esquecida

No tronco das árvores só presta para poesia.[...]

Meu irmão agradeceu a Deus aquela

permanência em árvore porque fez amizade com

muitas borboletas. ${ }^{225}$
\end{abstract}

Ao ler a arte poética de Manoel de Barros, suspendemos o tempo profano e passamos a habitar, de súbito, um tempo outro: o tempo da graça - infinito enquanto dura o encanto. Sua obra faz o leitor entrever a vida como horizonte e o estar vivo como promessa de um eterno buscar-se. Assim, a experiência de ler Manoel de Barros traz ao leitor uma possibilidade de ascender à criança e reaprender a deslumbrar-se com a imensa grandeza do que é ínfimo, pois daí se descortina o amanhecer.

Com ele, o leitor desexplica, desaprende, deslê. De sua paisagem poética, de fato, o leitor fotografa o canto da natureza, o silêncio das origens, o invisível do milagre, e percebe-se sendo árvore, transubstanciando-se 'homo significans'.

O autor reconstrói a humanidade em seu espaço banal, residual - tendo como referência, obviamente, a avassaladora difusão do espaço mercadológico -, à revelia da racionalidade pragmática e a serviço da plenitude do homem e da vida. Apresenta a contraface da racionalidade hegemônica, despertando a possibilidade de sermos o que somos ou ao menos de desejarmos ser diversos. O espaço por ele sonhado constitui-se menos como um quadro de vida e mais como um espaço vivido, um lugar de experiência e de revelação, prenhe de significado e de possibilidades de reflexão sobre nosso passado e futuro. A matéria de sua poesia são pré-coisas, isto é, o autor tem sensibilidade de captar as coisas em seu princípio, em seu instante primeiro, sagrado, antes de serem coisificadas pela civilização e pelo capitalismo.

${ }^{225}$ BARROS, Manoel. Ensaios fotográficos. 5.ed., Rio de Janeiro, Record, 2005. p. 63. 
Manoel de Barros devolve ao homem da racionalidade a afetividade, o mito, o delírio, sua parte sombra, seu lado 'demens', 'ludens', 'imaginarius', 'poeticus' de que trata Edgar Morin ${ }^{226}$.

Seu projeto de resistência apresenta muitas faces, entre as quais: recusa às degradações ambientais, à uniformização e quantificação, à vida prosaica puramente utilitária, à primazia do consumo, à tirania do dinheiro, ao pensamento único. Propõe a recuperação das raízes, o olhar rasteiro ao chão. Realmente vai às fontes não contaminadas. Põe a Mãe-natureza como casa, como jardim comum a todos os seres. Ensina-nos que somos filhos, ao mesmo tempo de nosso chão e da Terra, portanto compartilhamos o mesmo destino. Irriga-nos da vontade de desenvolver nossas múltiplas identidades: a de nossa etnia, a de nossa pátria, a de nossa comunidade de civilização, a de cidadãos terrestres e até a de não ter identidade humana, ser um misto de homem e árvore, comungado com a natureza. Toda essa luta se faz pelos subterrâneos do imaginário, pela fala mitopoética que "deplora as úlceras que o dinheiro fez e faz na paisagem", conforme afirma Alfredo Bosi $^{227}$.

Com sua poesia-toupeira ${ }^{228}$ - porque cava galerias subterrâneas e transforma o subsolo antes mesmo de modificar a superfície - leva-nos ao entendimento de sermos filhos de uma mesma e única mãe: a natureza. As infinitas vozes que ressoam em seus poemas compõem um concerto a céu aberto, imantando um sentimento forte de destino comum.

Natureza é fonte primordial?
- Três coisas importantes eu conheço: lugar
apropriado para um homem ser folha; pássaro que se
encontra em situação de água e lagarto verde que
canta de noite na árvore vermelha. Natureza é uma
força que inunda como os desertos. Que me enche
de flores, calores, insetos, e me entorpece até a
paradeza total dos reatores
então eu apodreço para a poesia ${ }^{229}[. .$.

\footnotetext{
${ }^{226}$ MORIN, Edgar. Os sete saberes necessários à educação do futuro. 8.ed., São Paulo, Cortez, 2003. ${ }^{227}$ BOSI, Alfredo. O ser e o tempo da poesia. 6.ed., São Paulo, Cia das Letras, 2000. p.173.

${ }^{228}$ Poesia-toupeira deriva da idéia de princípio da toupeira retirada de um dos seis princípios de esperança de Edgar Morin (MORIN, Edgar. Educar na era planetária: o pensamento complexo como método de aprendizagem no erro e na incerteza humana. São Paulo, Cortez, 2003. p.111).

${ }^{229}$ BARROS. Manoel. Arranjos para assobio. 4.ed., Rio de Janeiro, Record, 2002. p.38.
} 
Assim em travessia, na abertura da janela do trem, o leitor vê, revê, transvê, sensivelmente, o mundo, a natureza externa e interna, experimentando instantes de plena reconciliação. Invade-Ihe a alma uma substancial mutação, favorecendo o encontro de um novo sentido à existência individual, nacional e planetária. Seu inventário poético - concerto umbilical primeiro - faz-se húmus para este milênio e tanto mais.

Enchendo nossos vazios com seus despropósitos e peraltagens, convida-nos a atravessar um rio inventado para, depois, alçar vôo de passarinho. Com sua arte de carregar água na peneira, Manoel de Barros $^{230}$ ensina-nos "que a liberdade e poesia a gente aprende com as crianças".

Pelas aberturas da janela do trem, que a cada movimento se alargam, conforme as sagradas paisagens vagueiam pelo nosso olho, ouvimos cantos cheios de nascentes, sentimos o aroma da esperança, saboreamos, no pleno do horizonte, o gosto do amanhecer.

\subsubsection{Simbologia das origens}

Árvores, aves, águas, pedras, toda a natureza vegetal, animal, mineral habita o ventre poético de Manoel de Barros, compondo um verdadeiro ecossistema simbólico. Valorizando a sabedoria oriunda desses três reinos sagrados, os títulos de suas obras associam elementos da natureza, como se observa em: O guardador de águas; Concerto a céu aberto para solos de aves; Para encontrar azul eu uso pássaros; Cantigas para um passarinho à toa; Poemas rupestres, Compêndio para uso dos pássaros.

Em seus textos, esses elementos naturais hibridizam-se em casamentos insólitos, como se observa em: "pedras que cheiram água"231,"os jardins se borboletam" 232;"um passarinho me árvore" 233.

Essas imagens singulares, compostas de elementos primordiais, em uma tessitura que revela as hierofanias cósmicas primeiras, plasmam, na imaginação do leitor, a experiência nascente, possibilitando o encontro com o sagrado pelas dobras

\footnotetext{
${ }^{230}$ BARROS, Manoel. Exercícios de ser criança. Rio de Janeiro, Salamandra, 1999.

${ }^{231}$ BARROS, Manoel. Retrato do artista quando coisa. 4.ed., Rio de Janeiro, Record, 2004. p.13-14.

${ }^{232}$ Idem, ibidem. p.13-14.

${ }^{233}$ Idem, ibidem. p.13-14.
} 
do imaginário. Cumpre ressaltar que, na obra do poeta brasileiro, não há predominância de uma simbologia, mas a convivência delas nesse ecossistema simbólico.

Assim, ao optar pela valorização da matéria primordial harmonizada na natureza, Manuel de Barros prossegue alargando os canais da percepção do leitor até que avance à origem do mundo. Dessa forma, o leitor vai destecendo sua aprendizagem e, gradativamente, reconciliando-se com a natureza, cumprindo, assim, por meio dessa simbologia das origens, a finalidade de seu projeto político e estético que, indubitavelmente, firma-se no sagrado.

Dentro desse novo Cosmos, fertilizado pelo ecossistema simbólico, no movimento de sacralização da natureza, do mundo, dos homens, das coisas, Manoel de Barros vai milagrando possibilidades de fazer o leitor amanhecer.

\subsection{Um pouco mais de poesia para amanhecer...}

Ao revelar seu projeto político de voltar às origens, glorificando o chão matogrossense, brasileiro, terrestre, fica evidenciado, também, seu projeto estético, pela forma selecionada para concretizá-lo: a poesia.

Cantando poeticamente as origens, Manoel de Barros devolve-nos o amanhecer da vida humana: a experiência da imagem, anterior à palavra, enraizada no corpo.

$\mathrm{Na}$ raiz de todo o processo da fala, segundo Alfredo Bosi ${ }^{234}$, reside uma vontade-de-significar que produz os fenômenos de expressão e de comunicação, realizados por meio de signos. A poesia - mais suprema forma de linguagem nasce como expressão do ritmo primordial. É o dizer primeiro do homem, provindo daquilo que ele ausculta dos ritmos misteriosos interiores - a respiração, as batidas do coração - e exteriores - do Cosmos. Para o teórico, "O som do signo guarda, na sua aérea e ondulante matéria, o calor e o sabor de uma viagem noturna pelos corredores do corpo" 235 .

Poesia é som e imagem. Confirma o eu poético de Manoel de Barros ${ }^{236}$ :

\footnotetext{
${ }^{234}$ BOSI, Alfredo. O ser e o tempo da poesia. 6.ed., São Paulo, Cia das Letras, 2000. p.51.

${ }^{235}$ Idem, ibidem. p. 52.

${ }^{236}$ BARROS, Manoel. Livro sobre o nada. 12.ed., Rio de Janeiro, Record, 2006. p.47.
} 
Carrego meus primórdios num andor.

Minha voz tem um vício de fontes.

Eu queria avançar para o começo.

Chegar ao criançamento das palavras.[...]

Quando a criança garatuja o verbo para falar o que

não tem.

Pegar no estame do som [...]

E continua o canto: "Poesia é a ocupação da palavra pela Imagem. Poesia é ocupação da Imagem pelo Ser"237.

Em consonância, afirma Alfredo Bosi ${ }^{238}$ : "o poder de nomear significava para os antigos hebreus dar às coisas a sua verdadeira natureza, ou reconhecê-la. Esse poder é o fundamento da linguagem, e, por extensão, o fundamento da poesia".

$\mathrm{O}$ poder originário de nomear, em forma de rito, por meio de palavras sagradas, dissolveu-se com o aparecimento da ciência e da ideologia dominante, que, hoje, nomeia as coisas. Nestes tempos de celeridade e de progresso, "furtou-se à vontade mitopoética aquele poder originário de nomear, de compreender a natureza e os homens, poder de suplência e união"239. É justamente essa vontade mitopoética que a poesia de Manoel de Barros busca resgatar.

Para Alfredo Bosi ${ }^{240}$, a poesia

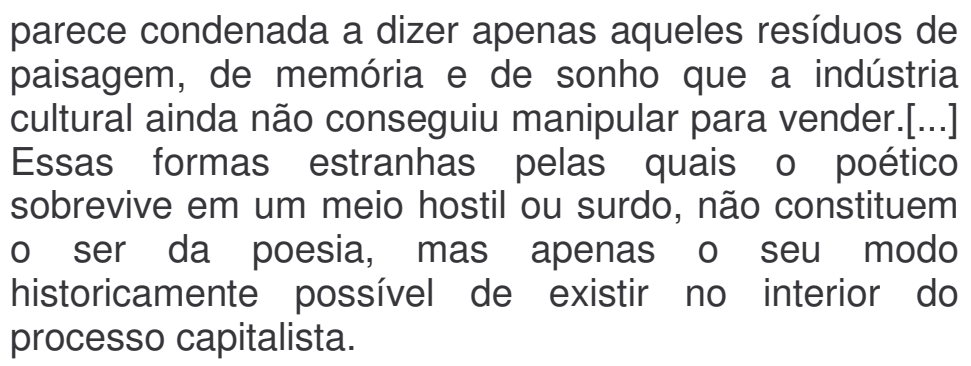

Esse novo modo de existir, se nos apropriarmos da teoria de Mircea Eliade, esconde, camufla o ser original da poesia. Ao rememorar esse ser original, a poesia de Manoel de Barros mostra-se como recusa da surdez e celeridade modernas e, ao mesmo tempo, resgata a dimensão sagrada que nela se abriga.

\footnotetext{
${ }^{237}$ BARROS. Manoel. O guardador de águas. 5.ed., Rio de Janeiro, Record, 2006. p.57.

${ }^{238}$ BOSI, Alfredo. O ser e o tempo da poesia. 6.ed., São Paulo, Cia das Letras, 2000. p.163.

${ }^{239}$ Idem, ibidem. p. 164.

${ }^{240}$ Idem, ibidem. p. 165.
} 
Alfredo Bosi ${ }^{241}$, ao dialogar com Vico e traçar o percurso da poesia, afirma:

houve uma idade primordial, em que a linguagem era quase muda, gestos e atos: tempo de deuses ctônicos, de gigantes, de homens-bestas. Entre aqueles atos e gestos, a maioria visava à interação social, mas, não se tendo ainda formado sequer os universais fantásticos, representava-se pelo desenho a intenção das mensagens. Assim, a primeira escrita foi icônica, ut pictura poësis, feita de hieróglifos, sagrados grifos. Vieram depois os tempos heróicos, já não mais imersos na terrível e sacra naturalidade. Articulam-se as palavras-frases, símbolos das relações entre o homem e o seu ambiente. Ao mesmo tempo (e Vico destaca a simultaneidade), inventa-se a escrita simbólica, que não é puramente imitativa, mas já um produto da atribuição comunitária de sentido a certas formas, ligadas por traços de afinidade, a certos significados. É um grau de abstração ainda não puramente lógico, mediado por 'significações análogas', as únicas que propiciam o aparecimento das formas poéticas.

\section{Ainda segundo o teórico ${ }^{242}$ :}

Do dizer selvagem ao "civil" dá-se uma progressiva mediação, um crescente alongamento no interior dos sistemas pelos quais se diz a relação entre o homem e o mundo. Os três processos - a) a imediação por gestos ou gritos; b) a articulação por universais fantásticos, ou narrativas (favolette) e c)o reagrupamento dos universais fantásticos em universais lógicos - são três sistemas, nascidos por necessidade, dominantes sucessivamente nas idades divina, heróica e civil, e recorrentes nos ciclos da História. A poesia (idealmente, o momento b) conserva, em qualquer tempo, o seu modo próprio de ser.

Na segunda fase, a poética, o processo de significação é "simbólico-formal e transmissível como signo, vindo a integrar um instituto da comunidade, a língua"243. Ainda conforme o referido teórico, a imagem, no poema, é uma palavra articulada, cuja superfície é uma cadeia sonora. "A matéria verbal se enlaça com a matéria significada por meio de uma série de articulações fônicas que compõem um código novo, a linguagem." ${ }^{244}$ A possibilidade de utilizar, figurativamente, a linguagem, que

\footnotetext{
${ }^{241}$ BOSI, Alfredo. O ser e o tempo da poesia. 6.ed., São Paulo, Cia das Letras, 2000. p. 252.

${ }^{242}$ Idem, ibidem. p. 243.

${ }^{243}$ Idem, ibidem. p. 253.

${ }^{244}$ Idem, ibidem. p. 29.
} 
vem como exigência e necessidade de simbolização dos primeiros homens, é característica das crianças e dos poetas. É da natureza da linguagem poética amalgamar gestos e sons do modo primeiro de significar com analogias características do discurso simbólico e articulado.

É a linguagem inaugural por meio da qual se torna possível falar dos deuses e da criação do mundo. Dizer inaugurador do mundo, experiência originária da linguagem, a poesia é portadora do sagrado.

Em Arranjos para assobio, o autor cria um "glossário de transnominações" com verbetes considerados importantes: cisco, poesia, lesma, boca, água, poeta, inseto, trapo, pedra, árvore.

Curiosa a forma como define poesia:

Poesia, s.f.

Raiz de água larga no rosto da noite

Produto de uma pessoa inclinada a antro

Remanso que um riacho faz sob o caule da manhã

Espécie de réstia espantada que sai pelas frinchas de

um homem

Designa também a armação de objetos lúdicos com

emprego de palavras imagens cores sons etc.

geralmente feitos por crianças esquisitas

loucos e bêbados ${ }^{245}$

Poeta é assim conceituado:

Poeta, s.m. ef.

Indivíduo que enxerga semente germinar e engole o

céu

Espécie de um vazadouro para contradições

Sabiá com trevas

Sujeito inviável: aberto aos desentendimentos como um rosto 246

O definir criador de Manoel de Barros faz-nos apreender o mundo pelos sentidos. Ensina-nos, também, a perceber, de forma enriquecida, a realidade que nos circunda, por meio de analogias. Assim nos sentimos perto das origens, das formas primeiras de percepção do mundo.

\footnotetext{
${ }^{245}$ BARROS. Manoel. Arranjos para assobio. 4.ed., Rio de Janeiro, Record, 2002. p.43.

${ }^{246}$ Idem, ibidem. p. 45.
} 
Segundo Alfredo Bosi ${ }^{247}$,

a forma do poema, quando vista nas suas constantes (nomes concretos, figuras, recorrências de som,,.), talvez seja uma sobrevivência de esquemas corporais antiqüíssimos. O que já exerceu uma função coesiva nas comunidades arcaicas reproduz-se, com funções análogas, no produto poético individual. Os cantos sagrados eram emissões da voz e do corpo inteiro em que se repetiam e alternavam expressões de encantamento, fusão afetiva com a comunidade, aleluia e exconjuro. A comunidade era possuída pela voz e pelo gesto com que impetrava as forças divinas espalhadas pela Natureza. Na poesia, esse movimento sobrevive na dinâmica da forma que realiza exercícios de analogia entre os seres (pela metáfora) ou de contigüidade (pela metonímia). E a dança em círculo cumpre-se no eterno retorno do ritmo.

Para Alfredo Bosi, poesia é fenômeno de linguagem, não de idéias. Para Manoel de Barros, também. Por isso, o poeta valoriza as analogias, as metáforas, as metonímias, porque a força do uso inédito das palavras sensibiliza o leitor. Sua linguagem mostra-se indisciplinada, pois, como revela: "a expressão reta não sonha"248.

Imprevista, a linguagem desse poeta ímpar põe o leitor mais a descobrir do que a descrever, mais a movimentar do que a estagnar.

[...] o que eu não gosto é de uma palavra de tanque. Porque as palavras do tanque são estagnadas, estanques, acostumadas. E podem até pegar mofo. Quisera um idioma de larvas incendiadas. Palavras que fossem de fontes e não de tanques. ${ }^{249}$

Para que seja fonte e não estanque, a poesia desobedece às ordens gramaticais e obedece à lógica da fala e do pensamento infantil, articulando-se como verdadeiro delírio verbal.

O poeta é aquele que sofre de "disfunção lírica", é o que "tem um parafuso trocado", cujos sintomas são sete:

\footnotetext{
${ }^{247}$ BOSI, Alfredo. O ser e o tempo da poesia. 6.ed., São Paulo, Cia das Letras, 2000. p. 143.

${ }^{248}$ BARROS, Manoel. Livro sobre o nada. 12.ed., Rio de Janeiro, Record, 2006. p.75.

${ }^{249}$ BARROS, Manoel. Memórias Inventadas - A Segunda Infância. São Paulo, Planeta, 2006.
} 
1. Aceitação da inércia para dar movimento às palavras.

2. vocação para explorar os mistérios irracionais.

3. Percepção de contigüidades anômalas entre verbos e substantivos.

4. Gostar de fazer casamentos incestuosos entre palavras.

5. Amor por seres desimportantes tanto como pelas coisas desimportantes.

6. Mania de dar formato de canto às asperezas de uma pedra.

7. Mania de comparecer aos próprios desencontros. ${ }^{250}$

Ensina Manoel de Barros ${ }^{251}$ : "Minhocas arejam a terra; poetas, a linguagem". Para arejar a linguagem, o poeta brasileiro vale-se de sua vocação para errar na língua portuguesa, para cada vez mais aproximá-la da língua dos índios e das crianças, até transmutá-la à linguagem dos pássaros. Dessa maneira, articula a língua de nosso chão, estendendo-a até a linguagem universal capaz de comungar homem e natureza.

Contenho vocação pra não saber línguas cultas.

Sou capaz de entender as abelhas do que alemão.

Eu domino os instintos primitivos.

A única língua que estudei com força foi a portuguesa.

Estudei-a com força para poder errá-la ao dente.

[...]

A língua dos Guaranis é gárrula: para eles é muito

Mais importante o rumor das palavras do que o sentido

Que elas tenham.

Usam trinados até na dor.

Na língua dos Guanás há sempre uma sombra do

Charco em que vivem.

Mas é língua matinal.

Há nos seus termos réstias de um sol infantil.

Entendo ainda o idioma inconversável das pedras.

É aquele idioma que melhor abrange o silêncio das

Palavras.

Sei também a linguagem dos pássaros - é só cantar. ${ }^{252}$

\footnotetext{
${ }^{250}$ BARROS, Manoel. Ensaios fotográficos. 5.ed., Rio de Janeiro, Record, 2005. p. 9.

${ }^{251}$ BARROS, Manoel. Livro de pré-coisas: roteiro para uma excursão poética no Pantanal. 4. ed., Rio de Janeiro, Record, 2003. p.59.

${ }^{252}$ BARROS, Manoel. Ensaios fotográficos. 5.ed., Rio de Janeiro, Record, 2005. p.18.
} 
[...] É língua muito transitiva a dos pássaros.

Não carece de conjunções nem de abotoaduras.

Se comunica por encantamentos.

E por não ser contaminada de contradições

A linguagem dos pássaros

Só produz gorjeios. ${ }^{253}$

Entorta o verbo até que fique anoitecido, pois, como revela em $O$ fazedor de amanhecer, "as coisas muito claras me noturnam". Ou em O guardador de águas:

\footnotetext{
O sentido normal das palavras não faz bem ao poema.

Há que se dar um gosto incasto aos termos.

Haver com eles um relacionamento voluptuoso.

Talvez corrompê-los até a quimera.

Escurecer as relações entre os termos em vez de aclará-los.

Não existir mais rei nem regências.

Uma certa liberdade com a luxúria convém. ${ }^{254}$
}

Seus arranjos poéticos revelam concisão, vigor, ritmo insólito, provocando estranhamento no leitor, e, inegavelmente, surpreendem.

Alquimista da palavra, o autor descarna o verbo até entrever seu cerne, sua estrutura seminal. Com linguagem, de língua brincada, opera no mais alto grau da potencialidade sonora, sintática, semântica, enfim, estética.

Sua arte poética tem a marca da sinestesia, cruza sentidos e sensações, porque, como revela, é feita com o corpo, para ser incorporada, não com a inteligência: "Escuto a cor dos peixes"255; "Cheiroso som de asas vem do sul"256; "Ouço o tamanho oblíquo de uma folha"257; "Quero apalpar o som das violetas."258

Acredita na palavra em seu aspecto primeiro:

De primeiro as coisas só davam aspecto

Não davam idéias.

A língua era incorporante ${ }^{259}$.

Por isso, pesca as palavras pela sensibilidade e, como um fotógrafo-contador, congela instantes do visível e do invisível:

\footnotetext{
${ }^{253}$ BARROS, Manoel. Retrato do artista quando coisa. 4.ed., Rio de Janeiro, Record, 2004. p.67.

${ }^{254}$ BARROS. Manoel. O guardador de águas. 5.ed., Rio de Janeiro, Record, 2006. p.63.

${ }^{255}$ BARROS, Manoel. O livro das ignorãças. 12.ed., Rio de Janeiro, Record, 2006. p.51.

${ }^{256}$ Idem, ibidem. p.52.

${ }^{257}$ Idem, ibidem. p.55.

${ }^{258}$ Idem, ibidem. p.59.

${ }^{259}$ Idem, ibidem. p.85.
} 
Difícil fotografar o silêncio.

Entretanto tentei. Eu conto:

Madrugada a minha aldeia estava morta.

Não se ouvia um barulho, ninguém passava entre

as casas.

Eu estava saindo de uma festa.

Eram quase quatro da manhã.

la o Silêncio pela rua carregando um bêbado.

Preparei minha máquina.

O silêncio era um carregador?

Estava carregando o bêbado.

Fotografei esse carregador.

Tive outras visões naquela madrugada.

Preparei minha máquina de novo.

Tinha um perfume de jasmim no beiral de um sobrado.

Fotografei o perfume.

Vi uma lesma pregada na existência mais do que na pedra.

Fotografei a existência dela.

Vi ainda um azul-perdão no olho de um mendigo.

Fotografei o perdão.

Olhei uma paisagem velha a desabar sobre uma casa.

Fotografei o sobre.

Foi difícil fotografar o sobre $[\ldots]^{260}$

Apreende as palavras pela sonoridade:

Certas palavras tem ardimentos; outras, não.

A palavra jacaré fere a voz

É como descer arranhado pelas escarpas de um serrote.

$[\ldots]$

Já a palavra garça tem para nós um

Sombreamento de silêncios...

E o azul seleciona ela! $!^{261}$

Afundo um pouco o rio com os meus sapatos

Desperto um som de raízes com isso

A altura do som é quase azul. ${ }^{262}$

Prioriza os versos livres e brancos, assegurando a espontaneidade do canto primeiro. Rimas, aliterações, assonâncias re-embalam os sons em sua invenção poética vibrante que apuram os sentidos e afinam o leitor com os compassos da música primeira.

\footnotetext{
${ }^{260}$ BARROS, Manoel. Ensaios fotográficos. 5.ed., Rio de Janeiro, Record, 2005. p.12.

${ }^{261}$ BARROS. Manoel. Concerto a céu aberto para solos de ave. 4.ed., Rio de Janeiro, Record, 2004. p.19.

${ }^{262}$ Idem, ibidem. p. 21.
} 
Muitas vezes, seu tom é tranqüilo, terno, franco, como o sopro primeiro, provocando movimentos de recriar contínuos na alma. Algumas vezes, principia em tom de humor, como de conversa cotidiana, mas finaliza em tom agudo de reflexão existencial, como na maior parte dos textos de Memórias Inventadas - $A$ infância e Memórias Inventadas - A segunda infância.

A pausa que entremeia os versos e marca o compasso da leitura é viva e profetiza o novo ou abriga a dúvida sanada pelos percursos que a significação vai entreabrindo.

Grande parte de seus textos concentra o tempo e o ritmo do poema primitivo, realçando os acentos da linguagem oral. Sua poesia é um canto nascido do rumor das palavras, preservando a oralidade, sem preocupação com a gramática:

Não oblitero moscas com palavras.

Uma espécie de canto me ocasiona.

Respeito as oralidades.

Eu escrevo o rumor das palavras.

Não sou sandeu de gramáticas.

Só sei o nada aumentando. ${ }^{263}$

Faz questão de trabalhar com a oralidade, como forma de combater o instituído, regrado, legislado, enaltecendo o inventado, espontâneo, nascido do chão.

Ao literato cujo fazia-lhe nojo a forma coloquial.

Queria captura em vez de pega pra não macular (sic)

A língua nacional lá dele...

O literato cujo, se não engano, é hoje senador pelo

Estado.

Se não é, merecia.

A vida tem suas descompensações.

Da velha draga

Abrigo de vagabundos e de bêbados, restaram

expressões: estar na draga, viver na draga por estar sem dinheiro, viver na miséria

que ora ofereço ao filólogo Aurélio Buarque de

Holanda

Para que as registre em seus léxicos

Pois que o povo já as registrou. ${ }^{264}$

\footnotetext{
${ }^{263}$ BARROS, Manoel. O livro das ignorãças. 12.ed., Rio de Janeiro, Record, 2006. p. 47.

${ }^{264}$ BARROS. Manoel. Poemas concebidos sem pecado. 4.ed., Rio de Janeiro, Record, 2005. p. 44.
} 
Reinventa a língua pela criação de um idioleto próprio: o "idioleto manoelês" arcaico, no qual são estabelecidas as feições da oralidade, a magia da voz:

Falar em archaico: aprecio uma desviação ortográfica para o archaico. Estâmago por estômago. Celeusma por celeuma. Seja este um gosto que vem de detrás. Das minhas memórias fósseis. Ouvir estâmago produz uma ressonância atávica dentro de mim. Coisa que sonha de retraves. ${ }^{265}$

Recria provérbios, adivinhas, como forma de diálogo às avessas com esses tempos arcanos: "Falando é que não se entende"266. Costuma usar onomatopéias na tentativa de recuperar ruídos primeiros. Segundo Alfredo Bosi ${ }^{267}$, "a onomatopéia e a interjeição teriam sido, quem sabe, formas puras, primordiais, da representação e da expressão". Surpreende o leitor ao reinventar a língua, por meio de neologismos, como estes retirados de Concerto a céu aberto para solos de ave: "abelhas novembras murmuram meu olho"; "Os morros me andorinham longemente..." "Eu me horizonto" 268 .

Emprega expressões regionais, fazendo com que o leitor ouça a voz do chão mato-grossense, do chão brasileiro.

O boi
de pau
era tudo que a gente
quisesse que sêsse:

Usa a repetição característica das estruturas frásicas primeiras:

Minha casa era caminho de um vento

Comprido comprido que ia até o fim do mundo 270

\footnotetext{
${ }^{265}$ BARROS, Manoel. Livro sobre o nada. 12.ed., Rio de Janeiro, Record, 2006. p.43.

${ }^{266}$ BARROS, Manoel. Livro de pré-coisas: roteiro para uma excursão poética no Pantanal. 4.ed., Rio de Janeiro, Record, 2003. p.70.

${ }^{267}$ BOSI, Alfredo. O ser e o tempo da poesia. 6.ed., São Paulo, Cia das Letras, 2000. p.50.

${ }^{268}$ BARROS. Manoel. Concerto a céu aberto para solos de ave. 4.ed., Rio de Janeiro, Record, 2004. p.39.

${ }^{269}$ BARROS, Manoel. Compêndio para uso dos pássaros. Rio de Janeiro, Record, 1999. p.21.

${ }^{270}$ Idem, ibidem. p. 22 .
} 
Aqui, a repetição busca resgatar o ritmo da oralidade próprio da narração de estórias. Insere palavras da língua indígena, pois elas espelham nosso chão e nossas raízes: "Esses lagartos curimpãpãs têm índole tropical."271

Aliás, muito da inovação de sua poesia vem do valor dado às raízes da fala, às raízes da cultura, pondo em evidência a gramática do índio, porque ela se constrói pela simplicidade, com a essência:

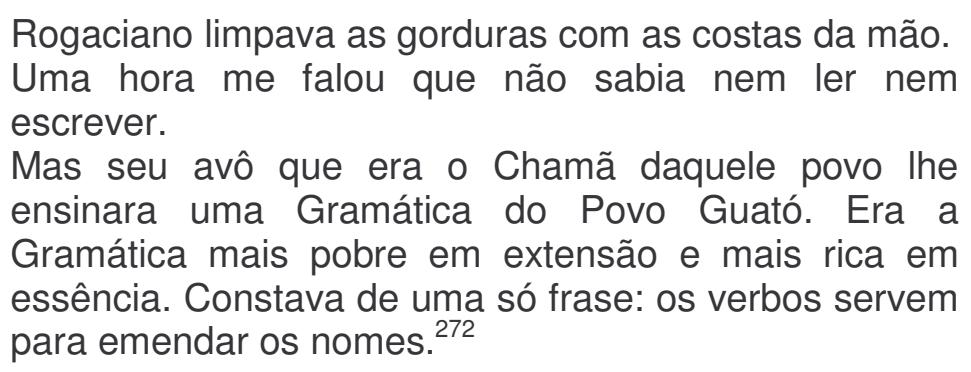

Rompe com as normas da pontuação, suprimindo vírgulas em enumerações, descartando ponto final para concluir frases, entre outras ocorrências, com o intuito de tornar presente o fluxo do pensamento e da própria oralidade. Com o mesmo objetivo, transgride as leis da colocação pronominal: "Me disse em línguapássaro"273; da ortografia: "Caminha sobre as conchas dos caracoes da terra"274; das sintaxes de regência: "E se riu." ${ }^{275}$, buscando sempre os desvios, porque eles surpreendem. Inventa, dessa forma, uma gramática muito menos lógica e muito mais afetiva.

Inverte a ordem dos termos da frase, altera a ordem direta, usual e lógica, provocando efeitos expressivos. Frases de um ou dois segmentos são recorrentes, revelando distanciamento da linguagem retórica e aproximação com a oralidade.

Verbos e nomes compõem a substância primordial da linguagem do autor, com os quais ele recupera a arte primeira de nomear:

os rios eram verbais porque escreviam torto

como se fossem as curvas de uma cobra.

Lesmas e lacraias também eram substantivos verbais

Porque se botavam em movimento.

Sei bem que esses nomes fertilizaram a minha

\footnotetext{
${ }^{271}$ BARROS, Manoel. O livro das ignorãças. 12. ed., Rio de Janeiro, Record, 2006. p.83.

${ }^{272}$ BARROS, Manoel. Memórias Inventadas - A Segunda Infância. São Paulo, Planeta, 2006.

${ }^{273}$ BARROS, Manoel. O livro das ignorãças. 12.ed., Rio de Janeiro, Record, 2006. p.81.

${ }^{274}$ Idem, ibidem. p.81.

${ }^{275}$ Idem, ibidem. p.87.
} 
linguagem .

Eles deram a volta pelos primórdios e serão

para sempre o início dos cantos do homem ${ }^{276}$.

Dialoga com diversos gêneros textuais, desde propagandas até haicais, potencializando o uso de diferentes métricas, mostrando ao leitor sua habilidade de lidar com o diverso, ora ironizando a sociedade de consumo, ora sensibilizando pela concentração do máximo de significado no mínimo de palavras.

Entorta sintaxes, esconde palavras, enviesa significados, fazendo o leitor pescar, porque não oferece pronto. $\mathrm{O}$ uso da elipse faz com que o leitor realize operações mentais, a fim de preencher lacunas, tornando-o sempre participativo, criador:

Aprendo com abelhas do que com aeroplanos.

É um olhar para baixo que eu nasci tendo. ${ }^{277}$

A inversão do sujeito e do objeto rompe com a sintaxe acostumada, propondo novas relações e significados:

Um perfume vermelho me pensou.

(Eu contamino a luz do anoitecer?) $)^{278}$

Assim como muda a função dos objetos, muda a função das palavras:

Eu hei de nome Apuleio.

Esse cujo eu ganhei por sacramento ${ }^{279}$

Opera, permanentemente, com a contradição, por isso emprega paradoxos, antíteses: "Ando muito completo de vazios". ${ }^{280}$; "A minha independência tem algemas"281. E revela: "as antíteses me congraçam" ${ }^{282}$. Tudo isso porque vê o homem como ser em conflito.

Abusa da metalinguagem - o que traduz a consciência de seu fazer poético, de forma a tornar a poesia uma crítica da linguagem e o poeta um homem comum,

\footnotetext{
${ }^{276}$ BARROS, Manoel. Memórias Inventadas - A Segunda Infância. São Paulo, Planeta, 2006.

${ }^{277}$ BARROS, Manoel. Retrato do artista quando coisa. 4.ed., Rio de Janeiro, Record, 2004. p.27.

${ }^{278}$ BARROS, Manoel. O livro das ignorãças. 12.ed., Rio de Janeiro, Record, 2006. p.69.

${ }^{279}$ Idem, ibidem. p.35.

${ }^{280}$ Idem, ibidem. p.55

${ }^{281}$ Idem, ibidem. p.55.

${ }^{282}$ BARROS, Manoel. Livro sobre o nada. 12.ed., Rio de Janeiro, Record, 2006. p.49.
} 
destituído de seu papel de dominação dos seres e da natureza, nivelado a "coisa". Ao leitor, cabe o papel engajado de co-autor e não contemplador do inatingível.

[...] Mas pode uma palavra chegar à perfeição de se tornar um pássaro? Antigamente podia.

$[\ldots]$

Garatujei meus pássaros até a última natureza.

Notei que descobrir novos lados de uma

palavra era o mesmo que descobrir novos lados do Ser. ${ }^{283}$

Vale-se da intertextualidade, exigindo do leitor que desbrave seu acervo imaginário:
Não tenho proporções para Apuleio
Meu asno não é de ouro. ${ }^{284}$
Fazíamos meninagem com as priminhas à
sombra das bananeiras, debaixo dos laranjais.
Só de homenagem ao nosso Casimiro de Abreu. ${ }^{285}$
Todos eram iguais perante a lua. ${ }^{286}$

Nesse último exemplo, o diálogo é feito com as letras da lei, em uma tentativa irônica e crítica. Evidente que, perante a lei dos homens e do capital, não há igualdade, mas perante as leis da natureza, todos se irmanam.

Perdura a ironia, quando reverte até mesmo as letras da Escritura bíblica: "Nossa maçã é que come Eva"287.

Sua poesia não só transfigura a natureza como a humaniza. Daí o uso recorrente de personificação: "Os patos prolongam meu olhar... Quando passam levando a tarde para longe eu acompanho..."288; "O rio deve estar mais gordo."289; "quando as aves falam com a pedras e as rãs/com as águas - é de poesia que estão falando."290

\footnotetext{
${ }^{283}$ BARROS. Manoel. Concerto a céu aberto para solos de ave. 4.ed., Rio de Janeiro, Record, 2004. p.26.

${ }^{284}$ BARROS, Manoel. O livro das ignorãças. 12.ed., Rio de Janeiro, Record, 2006. p.35.

${ }^{285}$ BARROS, Manoel. Retrato do artista quando coisa. 4.ed., Rio de Janeiro, Record, 2004. p. 39.

${ }^{286}$ BARROS. Manoel. Poemas concebidos sem pecado. 4.ed., Rio de Janeiro, Record, 2005. p.65.

${ }^{287}$ BARROS. Manoel. Arranjos para assobio. 4.ed., Rio de Janeiro, Record, 2002. p.38.

${ }^{288}$ BARROS, Manoel. Livro sobre o nada. 12.ed., Rio de Janeiro, Record, 2006. p.29.

${ }^{289}$ Idem, ibidem. p. 29.

${ }^{290}$ BARROS. Manoel. Concerto a céu aberto para solos de ave. 4.ed., Rio de Janeiro, Record, 2004. p.58.
} 
Manoel de Barros humaniza as coisas e coisifica o homem. Entretanto, essa coisificação tem valor positivo. Coisificar para ele é chegar ao estado "coisal", essencial, ínfimo, ponto em que tudo assume grandeza.

Seu universo poético constrói-se por uma constelação de metáforas associadas a uma série de simbolismos relativos à natureza. Abusa das metáforas de bom efeito expressivo em que aparecem coordenados dois termos a um terceiro, sendo um deles empregado em sentido próprio e outro em sentido figurado, como em: "o chão tem altares e lagartos"291.

Prefere os substantivos concretos aos abstratos, pois neles se plasma 0 pensamento mágico; já os abstratos contêm idéias menos corpóreas.

Seu projeto estético opera com uma linguagem simples, nada fácil, que toca rasteira o chão das palavras, fazendo o leitor alçar vôo pelo evocar da natureza e da terra.

Decompõe, descoisifica a forma até decantá-la em essência. Deixa evidente que seu fazer poético se faz mais por encantamento, por instinto, e menos pelo pensamento: "Não é por fazimentos cerebrais que se chega ao milagre estético senão por instinto lingüístico"292. Isso não significa descartar a intencionalidade, pois é assim mesmo que ela se revela. É curioso o ritmo escolhido para seus poemas, em que se observa a valorização afetiva de algumas palavras-imagens, tais como "águas" e "trem", no poema a seguir, potencializando sua qualidade expressiva:

Acho vestígios de uma voz de pássaro nas águas.

Viajo de trem para o Internato.

Vou conversando passarinhos pela janela do trem $^{293}$.

Sua poesia oscila entre o efêmero e o eterno, entre o lírico e o grotesco, entre a forma fixa e o experimentalismo, entre a poesia e a prosa, entre o cantar e o contar. Incursiona pelos espaços ínfimos até atingir grandeza, plasmando uma forma que se faz pelo milagre da invenção.

\footnotetext{
${ }^{291}$ BARROS, Manoel. Matéria de poesia. 5.ed., Rio de Janeiro, Record, 2005. p. 31.

${ }^{292}$ BARROS, Manoel. Retrato do artista quando coisa. 4.ed., Rio de Janeiro, Record, 2004. p.81.

${ }^{293}$ BARROS, Manoel. Concerto a céu aberto para solos de ave. 4.ed., Rio de Janeiro, Record, 2004. p. 27 .
} 
Importa menos a "denúncia das palavras" e mais "a parte selvagem delas, os seus refolhos, as suas entraduras" ${ }^{\text {"294. }}$.

Sua obra substantiva, que hibridiza gêneros e formas, reúne impressões, memórias, situações vividas e sonhadas. Combina o primitivo e o moderno, variando do mito às mensagens (anti-) publicitárias urbanas.

Malabarista do verbo, sua obra celebra os sentidos, consagra a palavra, abençoa toda forma. Sua língua coloca-nos em estado de passarinho, concede-nos asas e horizontes, porque mostra suas múltiplas aberturas.

Essa letra brasileira nasce do chão, no qual se enraíza tudo o que não se compõe com a sociedade de consumo, sendo, portanto, inutilidade e despropósito, assim mesmo como o escritor a concebe e como a arte deve ser.

Manoel de Barros enverga ao chão todos os sentidos, leva aos ouvidos humanos sons e ritmos primordiais, emprega classes gramaticais e relações sintáticas inusitadas, colocando a língua em estado de exaltação e o leitor em êxtase. Garimpa, nas margens da palavra, o que ela tem de eterno, perscruta o valor no inútil, celebra a palavra pura, explora suas raízes de nascedouro. Revela-nos o milagre que acontece, invisivelmente, todos os dias no chão onde pisamos. Pesca o sagrado e o silêncio de tudo que pulsa imperceptivelmente.Transubstancia homem em natureza, devolve-Ihe à origem e recoloca-o, permanentemente, em estado de graça.

Achamos na beira do rio um sapo seco, e um pote. O pote estava de barriga aberta ao sol.(Depois eu falo do sapo.) Nas enchentes nem quase que não entravam as águas para dentro do pote. Por forma que o pote era seco e aberto aos ventos. Os bons ventos da tarde que entravam com areia e cisco pelo ventre aberto do pote. (Demoramos de dois anos para voltar àquele retiro)Agora, de volta, achamos o pote tibi e emprenhado. A barriga do pote fosse agora um canteiro arrumado. Estava bom de criar. Foi que veio daí um passarinho e cagou na barriga do pote uma semente de roseira. As chuvas e os ventos deram à gravidez do pote forças de parir. E o pote pariu rosas. E esplendorado de amor ficou o pote! De amor, de poesia e de rosas. E havia perto, por caso, um sapo destripado e seco. A abertura do ventre do sapo também se enchera de areia e cisco. Também se fizera ele um canteiro arrumado. Foi que outro passarinho veio e cuspiu

${ }^{294}$ BARROS, Manoel. O livro das ignorãças. 12.ed., Rio de Janeiro, Record, 2006. p.102. 
outra semente de rosa no ventre do sapo. E outra rosa nasceu na primavera. Foi um dia de glória para o nosso olhar. As rosas do sapo e do pote foram abençoadas de borboletas que pousavam nas roseiras. Houvemos júbilo! ${ }^{295}$

Sua poesia transforma a palavra que transforma o homem. A palavra banal ganha aura enigmática. Seu fazer poético é um verdadeiro achadouro ${ }^{296}$ : da criança que fomos, do adolescente em que nos tornamos, do adulto que tentamos ser e do andarilho-criança que talvez voltemos ser.

Eu sempre desejei que as minhas latas tivessem aptidão para passarinhos. [...] Elas ficam muito orgulhosas quando passam do estágio de chutadas nas ruas para o estágio de poesia. ${ }^{297}$

Escrever, para ele, é "cheio de casca e pérola", porque, "nas fendas do insignificante ele procura grãos de sol”298. Para entender sua poesia, é preciso escolher o caminho da sensibilidade, feito pelo entendimento do corpo, e não o caminho da inteligência, já que poesia não é para compreender, mas para incorporar.

— Difícil entender, me dizem, é sua poesia, o
senhor concorda?
- Para entender nós temos dois caminhos: o da
sensibilidade que é o entendimento do corpo; e o da
inteligência que é o entendimento do espírito.
Eu escrevo com o corpo
Poesia não é para compreender mas para incorporar
Entender é parede: procure ser uma árvore.

As palavras com que constrói seus arranjos poéticos são palavrasbrinquedos, passíveis de manusear e distantes da linguagem adulta, culta, pensada. Afastada do estabelecido, sua linguagem é sentida, tateada, ouvida com total arrebatamento.

\footnotetext{
${ }^{295}$ BARROS, Manoel. Memórias Inventadas - A Segunda Infância. São Paulo, Planeta, 2006.

${ }^{296}$ Referência aos buracos em que os holandeses escondiam ouro na sua fuga apressada do Brasil ensinamento da negra Pombada, remanescente de escravos do Recife, conforme texto Achadouros, em Memórias Inventadas - A Infância.

${ }^{297}$ BARROS, Manoel. Memórias Inventadas - A Infância. São Paulo, Planeta, 2006.

${ }^{298}$ BARROS. Manoel. Arranjos para assobio. 4.ed., Rio de Janeiro, Record, 2002. p.33 e 35.

${ }^{299}$ Idem, ibidem. p.37.
} 
Opta pela liberdade, ao invés de encarcerar a língua em uma única possibilidade de expressão. O papel da poesia é justamente este: de abrir à língua outras possibilidades de expressão distintas do cotidiano. O papel do poeta é tirar a língua de seu lugar corriqueiro, ordinário e transportá-la para o lugar extraordinário. Assim, com um oásis de imagens inesperadas e inventivas, aproxima sua poesia da criança, que ainda não se compôs com as leis da letra, as regras gramaticais, sintáticas semânticas da língua, por isso é capaz, como ele, de brincar com as palavras, de esconder-lhe os sentidos.

Buscando o inominado, o ainda não enclausurado pela regra, ou exilado pela definição, ele não só inventa, mas, sobretudo, des-inventa. No des-inventar, o autor re-apreende a realidade originária, pré-categorial, quase como uma totalidade viva, como a do mito, do rito, dos cantos primeiros. Quase, porque sua apreensão histórica é culturalmente orientada, preocupada com valores e anti-valores de sua formação social, sendo, portanto, mediada por uma ideologia.

Evidente que, na construção de seu universo poético, a consciência criadora opera com os dados primeiros da imaginação e da paixão - por isso, vemos a paisagem brasileira - de maneira a torná-los transparentes por meio de uma linguagem bem pouco transparente, que é a verbal. Nesse trabalho de escrita, produz os sentidos que se coadunam com sua posição ideológica, dando significado histórico às suas representações. Como afirma Alfredo Bosi ${ }^{300}$, "a consciência histórica é matriz das conotações".

No dizer do teórico, "o nível da consciência histórica tende a subir e a ocupar a mente do poeta moderno. Mas o desejo, que pulsa na imagem e no som, é indestrutível" ${ }^{301}$. A literatura não é apenas espelho da ideologia, mas é, também, resistência à ideologia. Assim, a poesia de Manoel de Barros, inscrita em uma formação social, carrega traços dessa ideologia e da contra-ideologia, como mostramos, recuperando, com isso, a relação vital do homem com a natureza e com os outros homens.

Ao colocar a linguagem em festa, entre música e verbo, desacostuma sentidos, desarrumando relações. Manoel de Barros ensina-nos uma palavra viva e lúdica, convertida em brinquedo, com a qual se pode reinventar a vida, o mundo, a letra.

\footnotetext{
${ }^{300}$ BOSI, Alfredo. O ser e o tempo da poesia. 6.ed., São Paulo, Cia das Letras, 2000. p.144.

${ }^{301}$ Idem, ibidem. p.139.
} 
Recusa a palavra profana e esvaziada de significado, por seu sentido repetitivo e conhecido, afirmando a palavra sagrada, a que se liberta do sentido automatizado e instaura-se nova, recriada, palavra-selvagem, palavra-primeira, grávida de valor expressivo.

Sua literatura deixa entrever o mistério no interstício dos versos, revela a essência entranhada nas aparências. Essa linguagem inventiva, portadora de uma poética da des-aprendizagem, que põe à revelia valores firmados pela sociedade de consumo, faz emergir um mundo outro, transcendente e natural. Isso encanta o leitor, levando-o a um estado de divinamento.

Para Alfredo Bosi ${ }^{302}$, "a consciência que se volta, respeitosa e atenta, para o que não é ainda consciência - a pedra, a planta, o bicho, a infância - está prestes a cumprir a síntese entranhadamente poética de sujeito e objeto que se chama conceito concreto".

O olhar de Manoel de Barros sobre as coisas do mundo é inaugural, promove essa síntese de sujeito e objeto, de homem e natureza, como o faz a criança ou o primitivo. Não se trata de um olhar comum, bruto, míope, cego, incapaz de ver poesia nas coisas, mas de um olhar religioso, voltado para a comunhão com o sagrado.

Nas margens do texto, nas franjas da escritura, é esse olhar que nos convida a transver o mundo, por meio dessa poética da desaprendizagem, cujo ponto alto é a des-leitura, exercício capaz de nos re-ensinar a ler o mundo e nos aproximar da possibilidade de encontrar o sagrado na natureza e nas páginas do livro por meio da imaginação. No dizer do poeta: "o olho vê, a lembrança revê, e a imaginação transvê. É preciso transver o mundo"303.

Avançando para o começo, sua arte poética compõe-se com a magia da voz ancestral, com a força atávica do início do mundo, da vida e do homem. Valoriza, portanto, a percepção do homem quando nasce: o primeiro olhar, o primeiro toque, o primeiro gesto, o primeiro cheiro, o conhecimento primeiro nascido dos sentidos, o olhar de fonte e de água primeira. Flagra gestos primordiais de nossa linguagem e rumores e formas primeiras de nossa língua. Ressoa, em sua arquitetura poética, o início dos cantos do homem. Por isso, tanto seu projeto político quanto seu projeto estético somente se tornam possíveis pela presença do sagrado.

\footnotetext{
${ }^{302}$ BOSI, Alfredo. O ser e o tempo da poesia. 6.ed., São Paulo, Cia das Letras, 2000. p.179.

${ }^{303}$ BARROS, Manoel. Livro sobre o nada. 12.ed., Rio de Janeiro, Record, 2006. p.75.
} 
Poeta das insignificâncias, de todas as coisas ínfimas que pulsam dentro e fora de todo homem e o engrandecem, Manoel de Barros consegue transcender o circunstancial e alcançar o extraordinário. Sua letra se inscreve, com estilo pontiagudo, em pedra, em árvore, em pássaro e em homem.

Até agora, fizemos uma leitura horizontal das obras do autor, a fim de apreender sua cosmovisão e apontar traços singularizadores de seu projeto político e estético. Faremos, a seguir, uma leitura da obra Poeminhas pescados numa fala de João, com o objetivo de explorar o texto verticalmente, sobretudo as fulgurações do sagrado, nas duas linguagens que o compõem: a verbal e a visual. Essa obra, representativa da força expressiva do autor, será, posteriormente, cotejada com $O$ gato e o escuro de Mia Couto.

\subsection{Poeminhas pescados numa fala de João}

Os dez poemas que compõem o livro Poeminhas pescados numa fala de João, brilhantemente ilustrados por Ana Raquel, foram retirados do livro Compêndio para uso dos pássaros, especificamente da Parte I, que se intitula: De meninos e de pássaros. A forma como foram recriados em livro para crianças e jovens, enredando código verbal e visual, arremessa o leitor em trajetória duplamente sagrada, ao percorrer, como the aprouver, a água na proa da palavra, o ar no dorso das andorinhas (que povoam todas as páginas superiores), ou a terra, no balanço do trem (cujos trilhos percorrem a parte inferior das páginas do livro).

O próprio título da obra sugere conter poemas na fala de João. Em Matéria de poesia aparece a personagem João, sobre a qual se relata: "Um João foi tido por concha $[\ldots]^{304}$,. O uso do artigo indefinido "um" confere a João qualidade de ser um qualquer. Mais adiante confirma: “- Estou apto a trapo!"305. Assim, João possui as características de "coisa", portanto dele emana poesia. Como viaja muito ("viajou viajou na madrugada branca"306), também pode ser qualificado como andarilho, por isso manifesta a pulsão de busca infinita, agregando-se à natureza (coloca-a no bolso e foge) e ao divino. Sendo livre, é capaz de poetizar. De sua vasta experiência, manifestada na fala, recortam-se poemas que se enraízam no corpo:

\footnotetext{
${ }^{304}$ BARROS, Manoel. Matéria de poesia. 5.ed., Rio de Janeiro, Record, 2005. p.23.

${ }^{305}$ Idem, ibidem. p. 24.

${ }^{306}$ Idem, ibidem. p.28.
} 
nos pés ("a água dava rasinha de meu pé"307); nas mãos ("De minha mão dentro do quarto/meu lambarizinho escapuliu"308); nos ouvidos ("Escuto o meu rio"309); nos olhos ("Vi um rio indo embora de andorinhas"310); na boca ("jacaré comeu minha boca/do lado de fora" ${ }^{311}$ ). Nele se concentram as primeiras percepções do mundo, portanto, ele nos ensina das origens ${ }^{312}$.

Assim como João ${ }^{313}$ carrega no corpo a poesia, o eu poético carrega no bolso "um sol com passarinhos". Observa-se, de fato, que as vozes (do eu poético e de João) misturam-se nos poemas narrativos.

A natureza compõe-se com o corpo, nele se expressa, como pode ser reafirmado no fragmento:

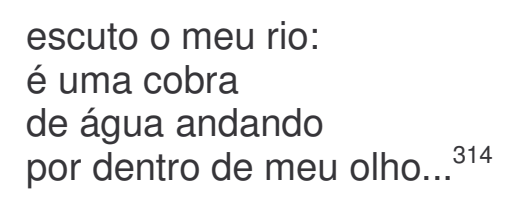

Logo, em seu dizer inaugurador do mundo, Manoel de Barros não exprime apenas resíduos da paisagem, mas reconcilia o homem com a paisagem, com a natureza, com o sagrado.

Por conceber a poesia como fenômeno de linguagem, não de idéias, o poeta associa gestos e sons primeiros com imagens, baseado em analogias, como se nota no fragmento citado acima. Essa forma de expressão é comum ao primitivo, ao poeta e à criança, uma vez que se distancia da lógica.

Em Poeminhas pescados numa fala de João, o fotógrafo-contador captura imagens da vida comum e rural e as traduz com a força das imagens sagradas da vida interna, com uma linguagem mais de descobrir do que de informar, mais de movimentar e mergulhar do que de estagnar. Assim também procede a ilustradora.

307 BARROS, Manoel. Il. Ana Raquel. Poeminhas pescados numa fala de João. 2.ed., Rio de Janeiro, Record, 2001.

${ }^{308}$ Idem, ibidem.

${ }^{309}$ Idem, ibidem.

${ }^{310}$ Idem, ibidem.

${ }^{311}$ Idem, ibidem.

312 A expressão "das origens" assume duplo sentido aqui, porque João nos ensina sobre as origens e, também, das origens, por pertencer, em estado de coisa, a elas.

313 Pela época em que foi escrito este poema - 1960 - é provável que Manuel de Barros esteja intratextualizando o célebre João Guimarães Rosa, a grande voz que nomeia essa nova realidade em que visível e invisível se entrelaçam.

${ }^{314}$ BARROS, Manoel. Il. Ana Raquel. Poeminhas pescados numa fala de João. 2.ed., Rio de Janeiro, Record, 2001. 
A voz que canta os versos parece ser um misto de criança e velho, pela capacidade de inventar, de expressar-se afetivamente ("Eu se chorei”), pela despreocupação com as leis da norma culta ("Tinha dois pato grande"; "Maria pegou ela pra criar"), pelas analogias lingüísticas ("você viu um passarinho abrido naquela casa"; "fazeu três araçás"); pela experimentação da oralidade ("depois, pan, caiu lá embaixo"; "pra mim"), pelo emprego de diminutivos ("meu lambarizinho"; boca pequenininha") e pela sabedoria existencial que provém do canto profundo, como o fragmento anteriormente citado.

O olhar que plasma as imagens visuais captura, sensivelmente, cada movimento, cada instante e, com linguagem caleidoscópica, reúne, em mosaico visual, desde imagens infantis, com traços elementares, formas e cores primárias, como o sol em forma de laranja ou a casinha vermelha de teto azul, até a fotografia, registrando, em memória, imagens do mundo exterior e evocando imagens do mundo interior, misturando o vivido e o imaginado, levando o leitor ora a reconhecer, ora a contemplar o espetáculo estético.

Com linguagem, de língua inquieta, o poeta atinge o máximo da estética. Assim também, insubmissa, a ilustradora, "com alma emprestada de passarim", desliza pelas múltiplas possibilidades imagéticas postas no horizonte da paisagem estética.

O lampejo poético pescado no exemplo anterior - "escuto o meu rio:/ é uma cobra/de água andando/por dentro de meu olho..." - contém, predominantemente, fonemas fechados (/o/ e /u/), associados a sons nasalizados (andando, dentro), que convidam o leitor à introspecção, ao mergulho nas águas interiores, em um tempo prolongado ao infinito (sugerido pelo uso do gerúndio e das reticências).

O movimento de comungar com o horizonte largo da natureza externa e de incursionar pelos misteriosos caminhos interiores é permanente nesta obra. No texto visual, os dois ambientes convivem, como se observa na ilustração que dialoga com o texto verbal. A fotografia, registro do mundo exterior, compõe-se com os traços primitivos da canoa, figuração do mundo interior. A roda-olho, posicionada no centro da página, serve de canal de comunicação, ou de espelho, para a relação entre o exterior e o interior.

O olho metaforiza o lugar de travessia do exterior ao interior, do não manifestado para o manifestado, do temporal para o eterno, portanto ele remete à Simbologia do Centro. 
De acordo com Mircea Eliade ${ }^{315}$, o Simbolismo do Centro pressupõe a Imagem do Mundo ('imago mundi') como um microcosmo. Trata-se de um espaço sagrado por excelência, no qual se manifestam as hierofanias. Nele se apresentam objetos sagrados ou símbolos hierocósmicos, tais como Pilastras do Mundo, Árvore Cósmica. Esses elementos podem ser observados na ilustração a seguir. E estão aliados a outros, como a cobra. A serpente, para o autor, é uma "hierofania do sagrado natural", "o primordial indiferenciado", "uma Coisa primordial indivisível que não cessa de desenrolar-se", "o potencial em que se originam todas as manifestações".

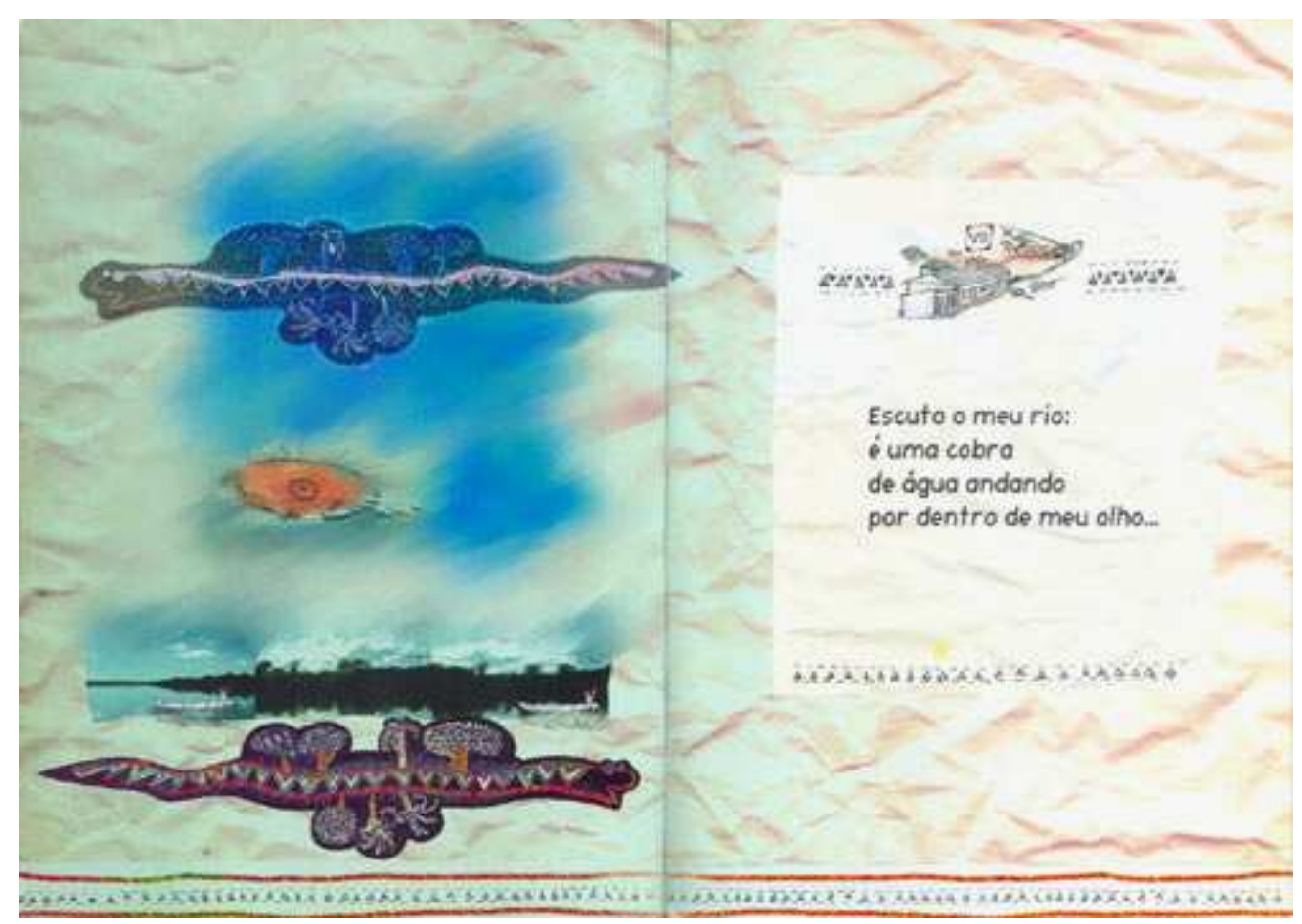

FIGURA 4.1

Essa reunião de elementos simbólicos manifesta o desejo de voltar às origens, ao coração da realidade. Cada espaço consagrado coincide com o Centro do Mundo, assim como cada tempo ritualizado corresponde ao tempo mítico do princípio. Essa página confirma ter a ilustradora captado, plenamente, o projeto estético do autor.

315 ELIADE, Mircea. O sagrado e o profano: a essência das religiões. Trad. Rogério Fernandes. Lisboa, Edição Livros do Brasil.s.d. p.49-66. 
Ainda segundo Mircea Eliade ${ }^{316}$, o Simbolismo do Centro revela sempre um lugar sagrado em que todas as forças se unem para promover a passagem de um modo de ser a outro, ou seja, para realizar um ritual de iniciação. A mandala, o círculo, o labirinto favorecem a concentração, o achar-se no centro. Para esse Centro, todo ser humano converge, porque é uma área irradiadora de sacralidade, a realidade integral. Como explica o historiador das religiões: "[...] o Centro é o âmbito do sagrado, a zona da realidade absoluta. De modo semelhante, todos os demais símbolos da realidade absoluta (árvores da vida e imortalidade, fontes da juventude etc.) encontram-se também situados em lugares centrais" 317.

Para Jean Chevalier e Allain Gheerbrant ${ }^{318}$, o Centro é "o foco de onde parte o movimento da unidade em direção à multiplicidade [...] e onde se reúnem, como em seu princípio, todos os processos de retorno e de convergência em sua busca da unidade".

O rio - símbolo da existência humana, do curso da vida - em sua fluidez, carrega a memória, as imagens primeiras, as experiências sagradas primordiais.

Os poemas que flutuam no rio, em folhas que parecem ter sido amassadas e desdobradas, metaforizam a poesia passível de ser encontrada na vida, para a qual não nos despertamos, ou ainda, representam as fulgurações do sagrado que compõem nossa existência para as quais nos cegamos.

Essa página concentra, em texto visual enredado a texto verbal, imagens da mais alta sacralidade.

O que se vê no mundo externo é uma espécie de espelhamento do mundo interno. E a imagem real contém os mesmos símbolos da imagem virtual, invertida. Uma olha para o futuro, em composição com a outra, que aponta para o passado.

Esse espelhamento pode ser, também, observado na composição da capa e contracapa.

\footnotetext{
${ }^{316}$ ELIADE, Mircea. Mito do eterno retorno. Trad. José Antônio Ceschin. São Paulo, Mercuryo, 1992.

${ }^{317}$ Idem. Ibidem.. p.27.

${ }^{318}$ CHEVALIER, Jean et GHEERBRANT, Allain. Dicionário de símbolos: mitos, sonhos, costumes, gestos, formas, figuras, cores, números. Trad. Vera da Costa e Silva et al. 10. ed., Rio de Janeiro, José Olympio, 1996.
} 


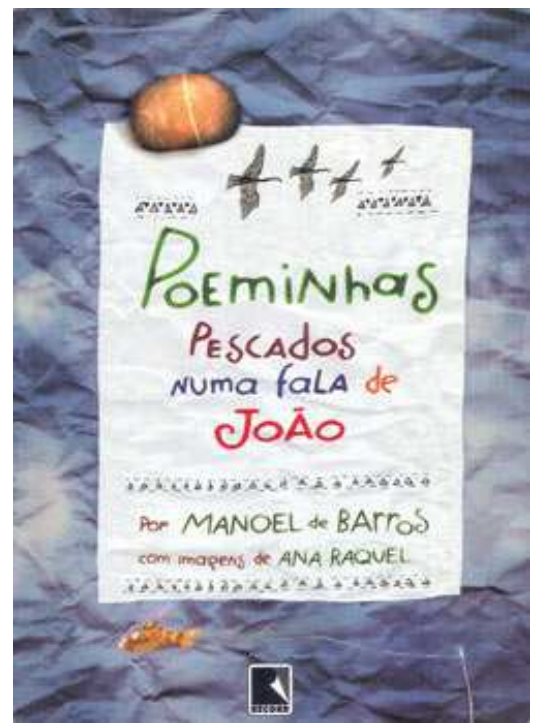

Figura 4.2

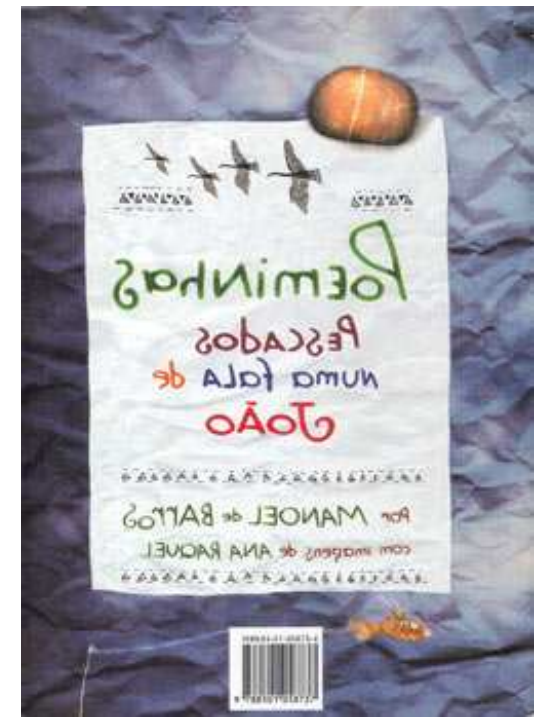

Figura 4.3

A relação da percepção-consciência passa pelo olhar e é metaforizada, igualmente, pela imagem do espelho - objeto a partir do qual Pierre Mabile ${ }^{319}$ definiu o parentesco entre 'se mirer' (mirar-se) e 'merveille', maravilha. A travessia que se faz com o olhar coloca o leitor em estado de maravilha. Atravessar o livro é conhecer um mundo outro para compreender, pelo estranhamento, pelas fulgurações do sagrado, os horizontes que se abrem para a libertação. Epifânica, essa travessia é rápida, tem o tempo de duração de uma folha que cai - como se percebe pelo espelhamento da capa-contracapa, ou mesmo o tempo da respiração daquele que atravessa um trecho do rio. Na trajetória, o leitor assume dois pontos de vista: de quem vê, no início, de fora e de cima (capa) e de quem mergulhou e aprendeu a ver de dentro e de baixo (contracapa). Depois, enriquecido, refaz o movimento ciclicamente.

Se o tempo profano é homogêneo, contínuo, linear, histórico, irreversível, esse tempo sagrado que envolve o leitor mostra-se heterogêneo, descontínuo, premia-o com a possibilidade de reversão, porque é circular e a-histórico, permitindo o eterno retorno, no ensinamento de Mircea Eliade ${ }^{320}$. Assim, a imagem do olho, da cobra andando e do espelho reiteram esse movimento cíclico - elemento arquetípico - que faz conjunção dessa obra com a dimensão ritual sagrada.

\footnotetext{
${ }^{319}$ MABILE, Pierre apud TODOROV, Tzvetan. Introdução à Literatura fantástica. 3.ed., São Paulo, Perspectiva, 2004. p.130.

${ }^{320}$ ELIADE, Mircea. Mito do eterno retorno. Trad. José Antônio Ceschin. São Paulo, Mercuryo, 1992.
} 
O movimento permanente do mundo externo ao interno, do olhar de cima ao olhar de baixo, do fim ao início, do profano ao sagrado, ao qual Manoel de Barros lança o leitor, constitui o exercício de des-aprendizagem necessário a quem se atreve transformar-se.

No texto verbal, esse movimento é também afirmado à medida que o eu poético conta o fato em terceira pessoa, para, em seguida, assumir seu ponto de vista em primeira pessoa, como se observa em:

Nain remou de uma piranha.

Ele pegou um pau, pum!,

Na parede do jacaré...

Veio Maria-preta fazeu três araçás pra mim

Meu bolso teve um sol com passarinhos...

Ora o leitor está em si, ora está no outro. Essa dinâmica favorece a vida compartilhada, transforma as relações sociais.

Ainda que cada poeminha pescado seja uma espécie de fotografia narrativa, nota-se o tempo a-histórico, próprio da poesia e da dimensão sagrada da existência. Não se pontuando pelo ritmo cronológico do relógio, as sensações e sentimentos narrados arquitetam-se de acordo com o nexo psicológico da lembrança do eupoético.

O uso das reticências, vale ressaltar, procedimento recorrente, nesta obra analisada, suspende o fluxo da fala e prolonga as imagens para ressoarem, no imaginário do leitor, por tempo infinito, transmutando o passado em eterno presente.

Esse tempo sagrado é também pescado pela ilustradora e evocado, no código visual, pelas andorinhas, que voam em círculo entre a capa e a contracapa, e pela presença do trem, que sugere a travessia das páginas-vida.

O ritmo, a entonação, o tom, associados à métrica de versos livres e brancos recuperam a magia da voz, presente na espontaneidade da fala, na afetividade da 'performance' característica da tradição oral. Assim, Manoel de Barros alinhava poesia em prosa. Utiliza verbos no passado e pressupõe um interlocutor imaginário com o qual dialoga, criativamente, sem os sinais característicos do discurso direto, mas respondendo até mesmo supostas perguntas, como se nota nos dois poeminhas: 
uma pedra em cima do rio.

Vento?

Só subindo no alto da árvore

que a gente pega ele pelo rabo.

Sua voz de recusa ao instituído engrandece o espontâneo, o infantil, o primordial, o nascido do chão brasileiro, como se observa nos fragmentos poéticos anteriores e em vários outros, bem como nas composições visuais que os acompanham.

Concisos, rápidos, sem solenidade, os poeminhas abusam das imitações sonoras, das onomatopéias, recuperando a fala primeira. Segundo Nilce Sant'Anna Martins $^{321}$, as onomatopéias são "transposições na língua articulada humana de gritos e ruídos inarticulados". Na obra analisada, apresentam-se onomatopéias que possuem valor definido dentro de nossa comunidade lingüística e são de uso corrente das crianças, como "tibum", "pan", "pum".

A palavra "priscava", enunciada no poeminha a seguir também é de origem onomatopaica:

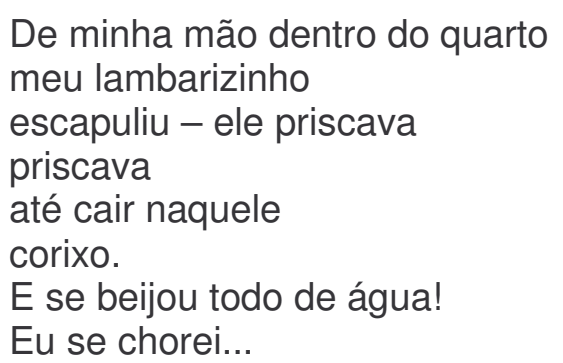

Essas imitações sonoras favorecem o máximo de sugestão imaginativa e tornam mais vivas as narrações poéticas.

Nesse texto, a constelação de sons sibilantes - provenientes das expressões "escapuliu", "priscava", "corixo", "beijou", "se chorei" - revela, fortemente, a malha expressiva do poema enredada no Simbolismo Aquático.

Nesta obra, especialmente por meio dessa simbologia, tanto Manoel de Barros quanto Ana Raquel recuperam o instante primeiro da criação do mundo, revelando a dimensão sagrada.

${ }^{321}$ MARTINS, Nilce Sant'Anna. Introdução à Estilística: a expressividade na língua portuguesa. 2.ed., São Paulo, T.A. Editor. 1997. p.47. 
Por meio desse elemento primordial - a água - o autor e a ilustradora traduzem um olhar religioso e acenam ao leitor para incursionar pelos territórios do divino, mesmo se configurando este de maneira camuflada.

Lembrando Mircea Eliade ${ }^{322}$ : "as revelações da sacralidade cósmica são de certo modo revelações primordiais: tiveram lugar no mais longínquo passado religioso da humanidade, e as inovações trazidas ulteriormente pela História não conseguiram aboli-las".

Ainda segundo o autor, "as águas simbolizam a totalidade das virtualidades", "substância primordial de que nascem todas as formas e para a qual voltam", "precedem qualquer forma e suportam qualquer criação", "símbolo da vida", "suporte do devir universal", "símbolo cosmogônico" ${ }^{323}$.

A maior parte dos poeminhas evoca a imersão na água - o que constitui ato simbólico e sagrado também. Trata-se de um ato de renovação, de purificação, do qual sai renovado o leitor. No dizer de Mircea Eliade ${ }^{324}$ :

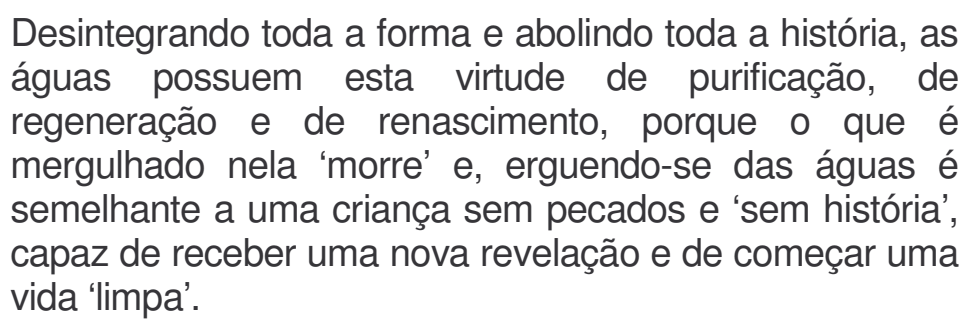

A ilustração, em consonância com o verbo, também leva o leitor à imersão, espécie de batismo visual. As primeiras imagens posicionam-no com os pés no raso da água. Cores mais claras, folhas grandes, o barco de papel que flutua, revelam o olhar de cima e de fora da água.

\footnotetext{
${ }^{322}$ ELIADE, Mircea. O sagrado e o profano: a essência das religiões. Trad. Rogério Fernandes. Lisboa, Edição Livros do Brasil.s.d. p.147.

${ }^{323}$ ELIADE, Mircea. Tratado de história das religiões. São Paulo, Martins Fontes, 1993. p.153-158.

${ }^{324}$ Idem, ibidem. p. 158 .
} 


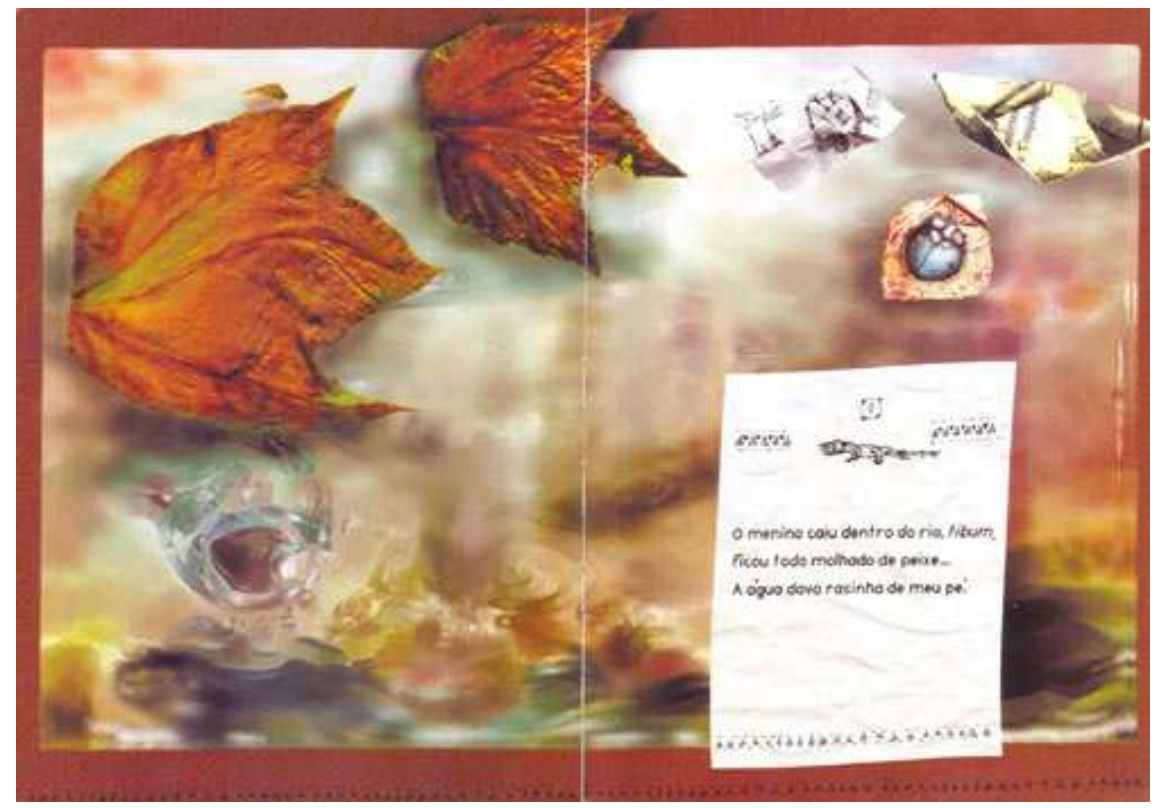

Figura 4.4

Na página seguinte, percebe-se que o leitor já mergulhou. Essa sensação é provocada pela cor mais escura, pela presença dos peixes, que soltam bolhas de ar, e pela mudança do ponto de vista, agora inferior, pelo ângulo de baixo para cima, evidenciado, também, pelo "casco" do barco de papel.

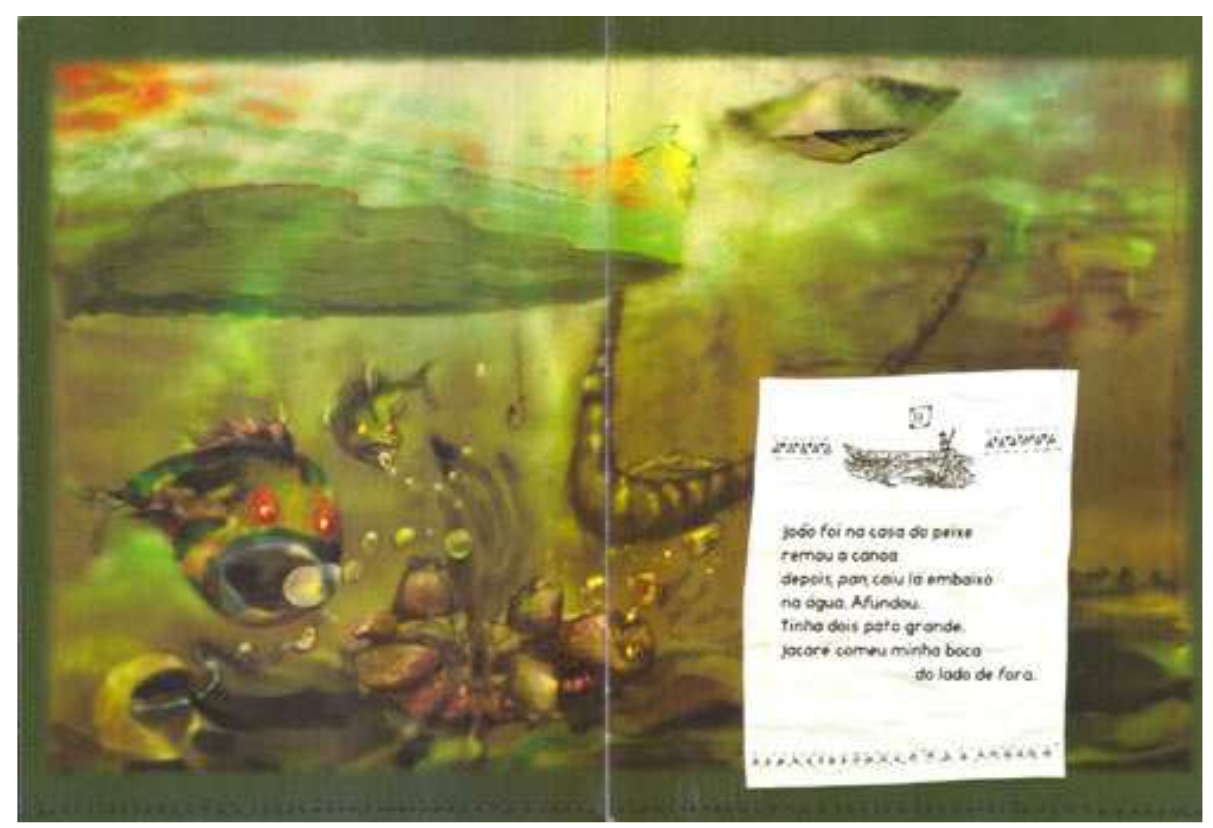

Figura 4.5 
Na última página, o ângulo é superior, o movimento de emersão do peixe conduz o leitor à saída da água e à posição de pescador. Agora, ele se transforma em sujeito capaz de pescar. Porque, purificado, regenerado, restaurou sua integridade primordial, comungando com o divino.

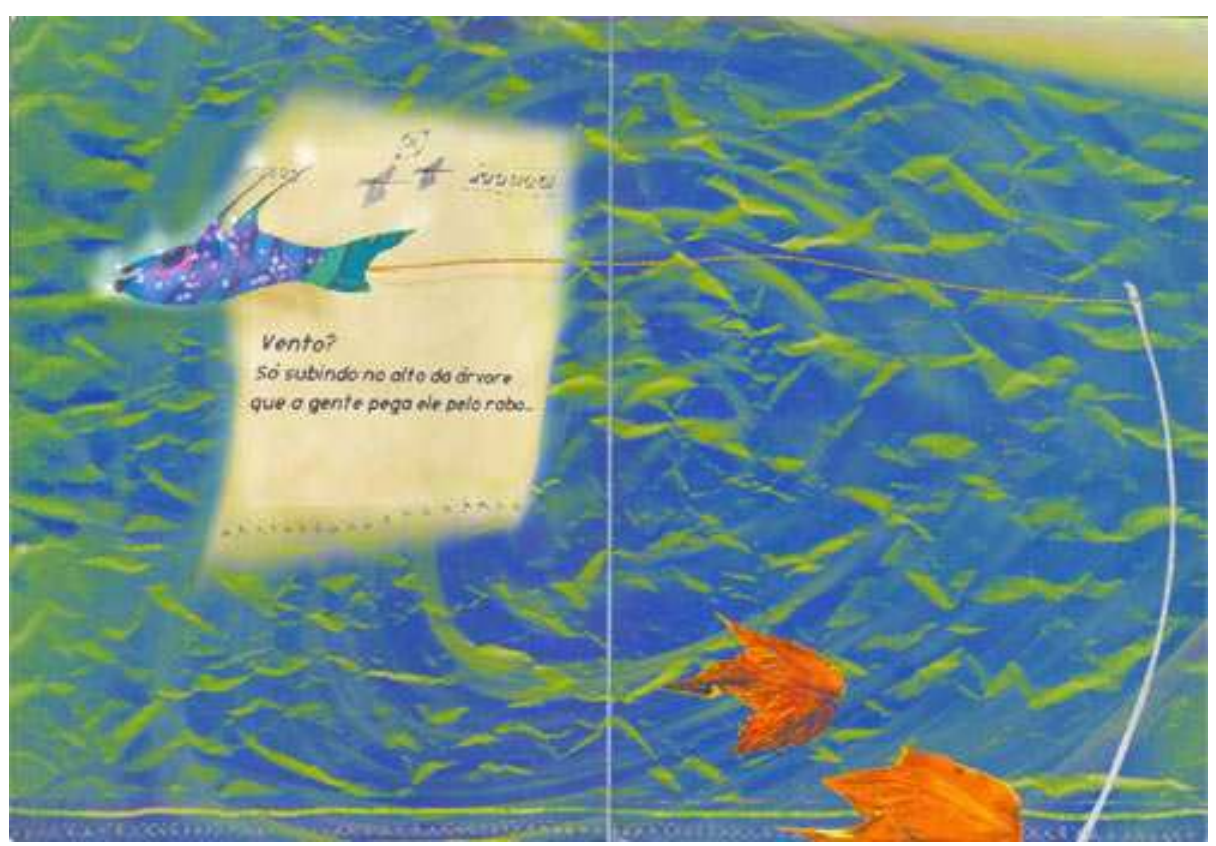

Figura 4.6

Assim se dá o processo de des-aprendizagem vivenciado pelo leitor em travessia imaginária. É o que ele des-aprende com o que pesca nos poemas falados por João, "tido por concha", símbolo aquático, além de outros, como peixe, jacaré, piranha, cobra, lambari, sapo.

A imersão na água - espécie de batismo - devolve o leitor 'ab origine', leva-o a encontrar-se 'in illo tempore', naquele tempo da criação, preparando-o para uma nova vida, de forma a torná-lo um novo homem, uma nova criatura.

Para Mircea Eliade ${ }^{325}$,

A purificação pela água possui as mesmas propriedades: na água, tudo se 'dissolve', toda a 'forma' se desintegra, toda a 'história' é abolida; nada do que anteriormente existiu subsiste após uma imersão na água, nenhum perfil, nenhum 'sinal', nenhum acontecimento'. A imersão equivale, no plano humano à morte, e, no plano cósmico à catástrofe (dilúvio) que

${ }^{325}$ ELIADE, Mircea. Tratado de História das religiões. São Paulo, Martins Fontes, 1993. p.158. 
dissolve periodicamente o mundo no oceano primordial. Desintegrando toda forma e abolindo toda a história, as águas possuem esta virtude e purificação, de regeneração e de renascimento, porque o que é mergulhado nela morre, e erguendo-se das águas, é semelhante a uma criança sem pecado e sem história, capaz de receber uma nova revelação e de começar uma vida limpa.

Essa é a força-motriz que imanta o sonho diurno ${ }^{326}$ de Manoel de Barros nesta obra. Pelo seu momento histórico, ele é capaz de sonhar para o Brasil uma nova forma de existir, um novo modo de estar no mundo, para o qual se torna necessário lavar o passado, purificá-lo de tudo o que se construiu com os valores do pecado e se lançar ao futuro, como criança, aberta a todas as possibilidades. $E$ isso só é possível pelo mergulho nas águas, pela simbologia que guarda as forças sagradas da imersão.

Curiosa a forma como alguns críticos comentam sua poesia. Lúcia Castelo Branco, em $O$ guardador de águas, denota: "Água de palavra. Água de letra. Água de escrita. É possível escrever na água? Em Dialeto-Rã, este livro se escreve. São macerações de sílabas, inflexões, elipses, refegos, o que ouvimos não apenas o guardador mas as águas que ele guarda".

A "poesia líquida" de Manoel de Barros atrai pela virtualidade do que evoca, pelas múltiplas possibilidades da língua, pelo informe do discurso sugerido. Ali a língua se desloca, desliza para o desconhecido e inusitado, revelando a infinidade dos possíveis. Ali ela retorna às origens, regenera-se, emergindo forte e pura, substantiva, fértil, sem margens, sem limites, matéria-prima enlaçada com a criança - água-palavra com a qual o poeta plasma imagens.

A imagens criadas, figurativamente, revelam a afetividade com que os dois alquimistas operam: um da língua, outro da imagem.

Fundada na analogia, a metáfora traduz-se como uma comparação induzida pela associação de duas representações. Imagens concretas, sensíveis, imaginativas compõem a teia metafórica do poeta, como: "João foi na casa do peixe"; "ficou todo molhado de peixe";"meu bolso teve um sol com passarinhos".

\footnotetext{
${ }^{326}$ Conforme Benjamin Abdala Junior, inspirado em Ernst Bloch: sonho diurno "é o sonho de quem procura novos horizontes [...] Essa atitude é mais adequada do que o sonho noturno, que teima obsessivamente em olhar para trás, melancolicamente contemplando as ruínas". (ABDALA JR., Benjamin. De vôos e ilhas: literaturas e comunitarismos. São Paulo, Ateliê Editorial, 2003. p.18).
} 
Símiles também aparecem, tornando a linguagem rica em teor afetivo, como na frase: "Minha boca estava seca igual do que uma pedra em cima do rio". O nexo gramatical ("igual do que") que evidencia a comparação revela o pitoresco da fala, a linguagem popular e regional, evocando a cor local do sertão, também revelada pela dupla negativa da frase: "Ninguém não tinha um rosto com chão perto".

Metonímias são recorrentes em sua obra e nesta, em especial, resgatam a imagem do contador ou do pescador que narra estórias mágicas:

De dia apareceu uma cobrona debaixo de João.

Eu matei a boca pequenininha daquela cobra. Ninguém não tinha um rosto com chão perto.

Matar a boca pequenininha da cobra enaltece o eu poético-narrador, portador de força, de grandeza. Isso é enfatizado pelo contraste do aumentativo ("cobrona") e do diminutivo ("pequenininha"), acentuando valor afetivo do enunciado, em um uso da linguagem que se afasta, intencionalmente, da lógica.

Personificações também compõem o inventário afetivo de Manoel de Barros, como se observa: "João foi na casa do peixe". Casa tem a marca afetiva próxima de um lar. Essa forma de tornar humano o não humano é comum na linguagem infantil e revela a força expressiva da linguagem dos princípios.

O mesmo ocorre no poeminha a seguir:

A noite caiu da árvore.

Maria pegou ela pra criar e ficou preta...

Vi um rio indo embora de andorinhas.

Essa mesma forma mágica do pensar aproxima o leitor da maneira primeira de expressar do homem, construída com elementos de sua vivência concreta.

Assim como o escritor no texto verbal, a ilustradora, no texto visual, opera, afetivamente, com figuras de linguagem: metáforas visuais (o sol é uma laranja), resgatando o desenho infantil; metonímias (o lápis e o carrinho), evocando a criança; e chega até a compor os elementos do discurso mítico, em uma combinação que perfaz seu aspecto maravilhoso, como na ilustração já apresentada (Figura 4.1) e na imagem a seguir: 


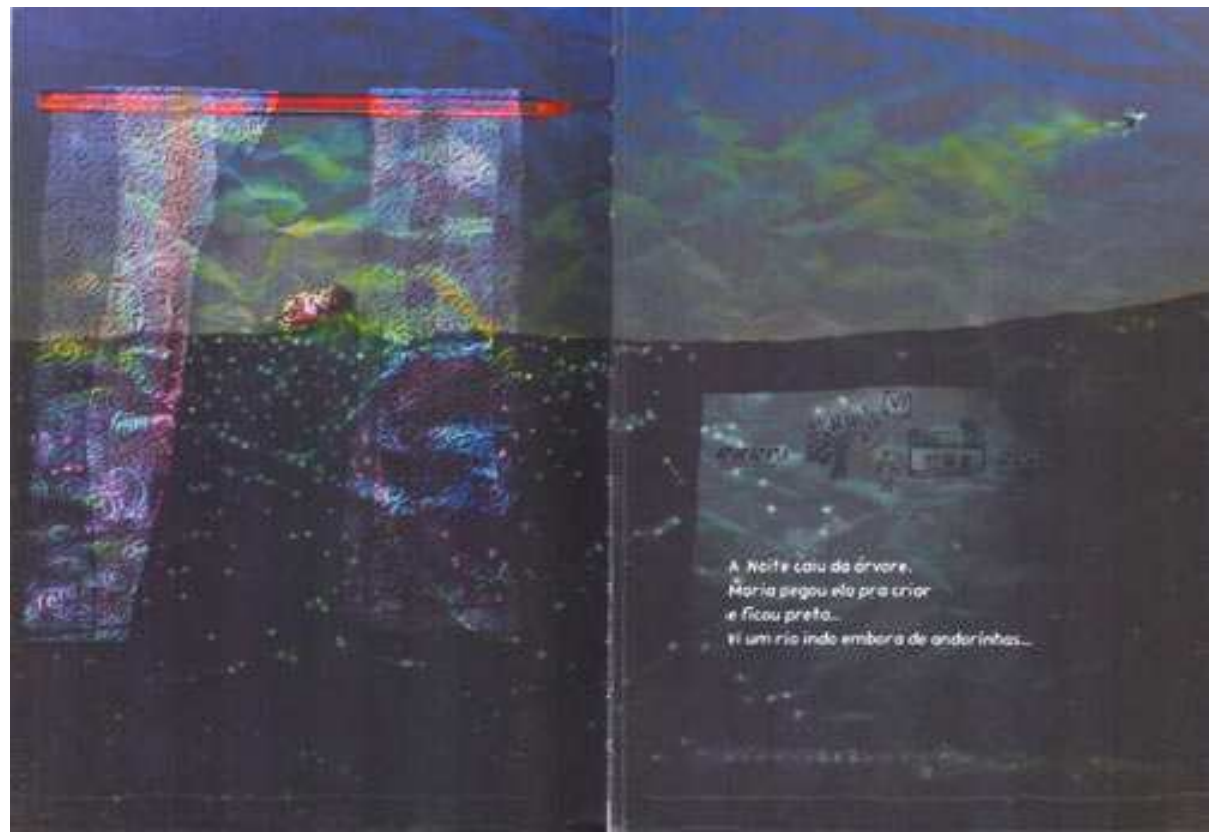

Figura 4.7

O mito trata de uma espécie de narração intuitiva do homem arcaico e, segundo alguns estudiosos, característica do pensamento mágico, germe do pensamento religioso. Para Mircea Eliade ${ }^{327}$, os mitos são modelos que preservam e transmitem os paradigmas, os modelos exemplares para as instituições, para as normas de conduta, além de outros e conferem valor à existência. Tais modelos paradigmáticos são revelados no início dos tempos e têm origem sobre-humana e transcendental. Portanto, ao recuperar esse discurso mítico, Manoel de Barros e Ana Raquel, novamente, colocam o leitor em contado com o sagrado.

Esse pensar mágico em que tudo vira tudo é característico da criança. Por isso, faz sentido, nesse mundo maravilhoso, o boi piar, o vento ser pego pelo rabo, o sapo de pau virar chão.

Ao resgatar a forma do discurso mítico, Manoel de Barros, em consonância com Ana Raquel, reinventam, também, elementos de nossa origem, como ser humano, como homem ocidental, como brasileiro, aproximando-nos do sagrado.

No resgate da tradição, especialmente, da tradição oral, mostra sua vocação para recusar a norma culta, a língua do colonizado. Daí sua preocupação em articular a língua oral do chão brasileiro, experimentando, mais uma vez, a proposta

\footnotetext{
${ }^{327}$ ELIADE, Mircea. Mito do eterno retorno. São Paulo, Mercuryo, 1992.
} 
modernista de fortalecer a língua que vem "da boca do povo na língua errada do povo/ língua certa do povo/ porque ele é que fala gostoso o português do Brasil." 328

No acervo poético de Manoel de Barros, desfilam frases marcadas por desvios altamente expressivos. Entorta sentidos, termos da oração, sintaxes, arejando a linguagem com construções extremamente originais, como se observa em: "ficou todo molhado de peixe"; "a água dava rasinha de meu pé"; "E se beijou todo de água", entre outras. Assim, faz a língua sonhar. E o leitor também.

A maior parte dos verbos do texto apresenta movimento, são nocionais, expressando o dinamismo da vida e dos fatos que a compõem: "remou", "caiu", "afundou", "comeu”, "fazeu", “matei”, “escapuliu", "priscava”, “beijou”, chorei”, entre outros.

Predomina período simples e período composto por coordenação, de forma que as orações, independentes, fiquem justapostas. Essa construção, de tom mais espontâneo, é bastante comum língua oral. Mais ágil, sugere seqüência rápida ou mesmo simultaneidade dos fatos. Dessa maneira, Manoel de Barros distancia-se do período solene, preferindo o período breve, ajustado à simplicidade das manifestações emotivas. Aliás, essa simplicidade permeia, também, o vocabulário. Apesar de palavras simples, de significação transparente, os arranjos poéticos não são fáceis, dado atingirem um grau de complexidade tamanho que faz acordar o leitor.

Ana Raquel opta, igualmente, pela simplicidade, na escolha das imagens. Entretanto, a forma como elas se compõem, nas páginas, revela complexidade e provoca vontade de descoberta no leitor.

Percebe-se em Manoel de Barros uma vocação para a errância. Ao atravessar os limites instituídos pelas leis gramaticais, livre, o poeta erra pela geografia da língua-mãe, faz malabarismos poéticos, salta a lógica, enlouquece os sentidos.

Transgride normas da pontuação, suprimindo vírgulas nas enumerações, evitando ponto final para concluir frases, abusando das reticências, retirando travessão e marcas comuns de diálogo; desvia-se da concordância nominal ("dois pato grande"), da colocação pronominal ("pegou ela"; "pega ele"); inventa regências ("eu se chorei"). Ao pescar os poeminhas da fala de João, carrega suas marcas de

${ }^{328}$ Conforme Manoel Bandeira, em "Libertinagem”, inserido no livro Estrela da Vida Inteira. 16.ed., Rio de Janeiro, José Olympio,1989. p.106. 
oralidade: onomatopéias; construções sintáticas inusitadas; construções próprias da fala infantil feitas por analogia ("Veio Maria-preta fazeu três araçás pra mim"; "você viu um passarinho abrido"); aumentativo e diminutivo que asseguram dramaticidade ao discurso e fortificam o traço heróico do "contador"; regionalismos; repetições ("meu lambarizinho/escapuliu-ele priscava/priscava"), alterações fonéticas ("pra"), entre outras.

Dessa forma, Manoel de Barros avança para o princípio, resgata a infância da língua e a tradição oral, marca identitária de nossa cultura. No final da obra analisada, faz esta desexplicação:

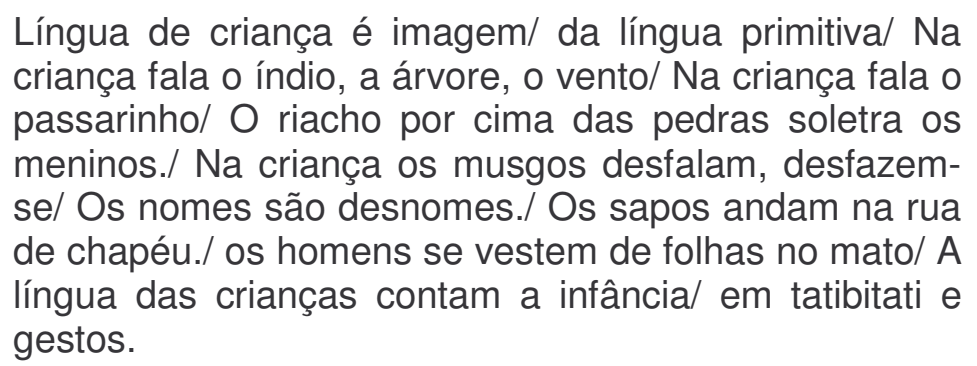

"Raiz de água larga"329, sua poesia põe nossa imaginação em revoada, com analogias, símiles, metáforas, metonímia, personificação - linguagem sensível que figura o uso "estranhado" do verbo.

Surpreende com peraltagens fonéticas, morfológicas, sintáticas, semânticas, dando as costas para a lógica e defendendo a intuição que encanta sua gramática afetiva e faz, permanentemente, o leitor pescar sentidos, tornando-se, também ele, vocacionado para a errância. Desse projeto participa, também, a ilustradora, ao inventar imagens que, por causar estranhamento, arregalam os olhos do leitor e favorecem sua des-leitura.

Esse projeto estético de des-aprendizagem - compartilhado por autor e ilustrador - que se desdobra no empoemamento do verbo, das cores e das formas e no criançamento da palavra e da imagem, recusando normas impostas e lógicas instituídas, toca o coração do leitor, colocando-o em estado inaugural. Ao experimentar a água da palavra e o sabor da imagem, o leitor captura as infinitas possibilidades expressivas capazes de levá-lo a compartilhar do milagre da criação.

${ }^{329}$ BARROS. Manoel. Arranjos para assobio. 4.ed., Rio de Janeiro, Record, 2002. p.43. 
E, em estado de plenitude, comunga com a força atávica do início do mundo, da vida e do homem.

O poeta escolhe a letra; a ilustradora, a imagem. Reconciliando o homem com a natureza, a poesia, verbal e visual, ganha força, sobretudo para enraizar-se no chão das origens.

Imagens da fauna, flora, cores da natureza brasileira refletem a alma de um Brasil-menino, protegido de toda dominação. Na travessia das águas, o leitor aprende a pescar, aprende a ouvir os clamores de nossos ancestrais e passa, também, a recusar o desmatamento da alma brasileira. $E$, mais do que ver, passa a ter visões de um amanhecer em que se possa celebrar a promessa de sermos gente, de sermos nós, de termos chão.

Por meio dessa palavra líquida, dessa linguagem fluida e andarilha, de código visual e verbal, curvados ao chão e coroados de sagrado, torna-se possível enraizarse, feito árvore, na terra sagrada da memória, rasgando aberto, feito pássaro, o céu do futuro.

Comungadas com o sagrado, nascem a imagem e a letra; enraizadas nele também podem reverter a História. 


\section{CAPÍTULO 5}

\section{MIA COUTO}

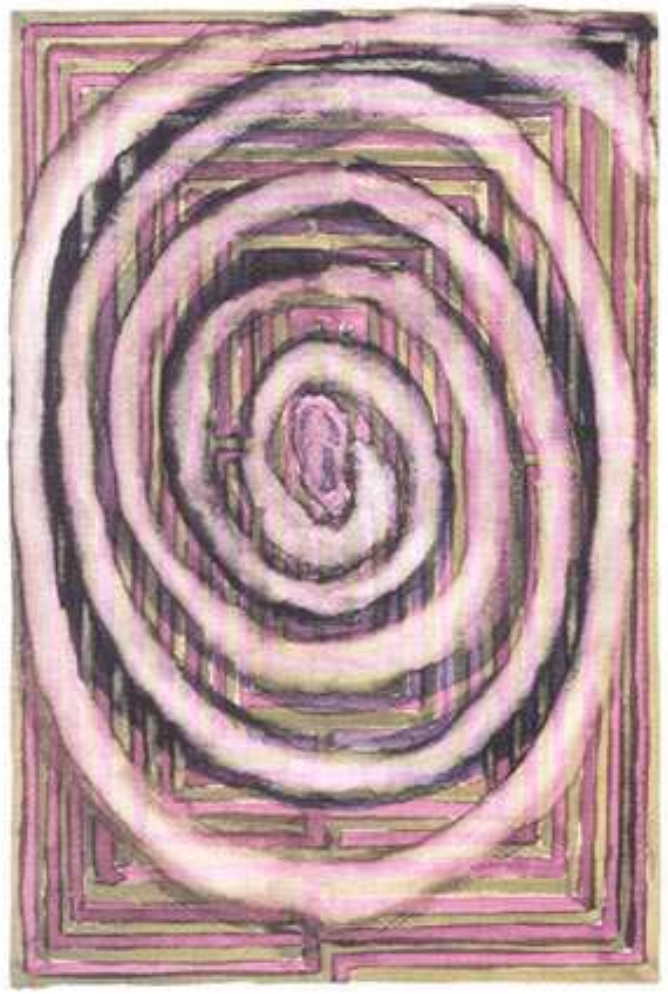

"Sou religioso sem religião. Sofro, afinal, da doença da poesia: sonho lugares em que nunca estive, acredito só no que não se pode provar."

(Mia Couto)

Ilustração 6 - arte de João Nasi Pereira para Estória abensonhadas de Mia Couto (1994) 


\subsection{No balanço do barco: em busca da ilha}

Convido o leitor, para apreciar, em viagem navegada, a paisagem imaginária da obra de António Emílio Leite Couto (Mia Couto), por amor confesso a gatos. É ali, da proa do barco, que visualizaremos a topografia estética desenhada por esse autor moçambicano, nascido em 1955, na Beira, por ele chamada de "minha água natal ${ }^{\prime 330}$, anunciador enraizado das vozes sagradas da tradição africana.

Enquanto navega o barco, observamos, com inquieta admiração, a paisagem, levando, na memória, o ensinamento de avô Celestiano ${ }^{331}$ : "Lançamos o barco, sonhamos a viagem: quem viaja é sempre o mar".

Nesse percurso, no balanço das ondas, realizaremos, também nós, a travessia iniciática - oportunidade ímpar de nos percebermos, como Mia Couto ${ }^{332}$, seres de fronteira, habitantes de um lugar grávido de possibilidades, um entrelugar.

Com os pés na história e as mãos na literatura, o escritor moçambicano responde a toda espécie de dominação, seja ao colonialismo, seja à globalização na sua forma perversa, com um projeto estético anunciador da escuta das várias vozes que, apesar de silenciadas, compõem a sinfonia humana. Por meio de um narrador que se reveste de contador, faz ouvir, nas curvas das letras, os ecos da oralidade.

Anuncia uma nova espécie de conhecimento, cuja lógica reflete a feição de sua cultura. Assim, em Pensatempos ${ }^{333}$, responde às questões postas hoje:

O que podemos fazer, nos dias de hoje, é responder à
globalização desumanizante com uma outra
globalização, feita à nossa maneira e com os nossos
próprios propósitos. Não tanto para contrapor. Mas
para criar um mundo plural em que todos possam
mundializar-se e ser mundializados. Sem hegemonia,
sem dominação. Um mundo que escuta as vozes
diversas, em que todos são, em simultâneo, centro e
periferia.[... Se os outros nos conhecerem, se

\footnotetext{
${ }^{330}$ COUTO, Mia. Pensatempos: textos de opinião. 2.ed., Lisboa, Editorial Caminho, 2005. p.145.

${ }^{331}$ COUTO, Mia. Il. João Nasi Pereira. Mar me quer. 5.ed., Lisboa, Editorial Caminho, 2000. p.17.

332 Em Pensatempos, Mia Couto afirma partilhar com sua cidade natal a condição de fronteira: "A minha cidade estava condenada a ser lugar de fronteira - entre o mar e o continente, entre o rural e o urbano, entre a Europa e a África. Sou moçambicano, filho de portugueses, nasci em pleno sistema colonial, combati pela Independência, vivi mudanças radicais do socialismo ao capitalismo, da revolução à guerra civil. Vim à luz num tempo de charneira, entre um mundo que nascia e outro que morria. Entre uma pátria que nunca houve e outra que ainda está nascendo".(COUTO, Mia. Pensatempos: textos de opinião. 2.ed., Lisboa, Editorial Caminho, 2005. p.150.)

${ }^{333}$ COUTO, Mia. Pensatempos: textos de opinião. 2.ed., Lisboa, Editorial Caminho, 2005. p.156.
} 
escutarem a nossa voz e, sobretudo, se encontrarem nessa descoberta um motivo de prazer, só então estaremos criando esse território de diversidade e de particularidade. O problema parece ser o de que nós próprios - os do Terceiro Mundo - nos conhecemos mal. [...] A visão que temos da nossa História e das nossas dinâmicas não foi por nós construída. Não é nossa. Pedimos emprestado aos outros a lógica que levou à nossa própria exclusão e à mistificação de nosso mundo periférico. Temos que aprender a pensar e a sentir de acordo com uma racionalidade que seja nossa e que exprima a nossa individualidade.

Ao mergulhamos no universo ficcional de Mia Couto, descobrimos uma nova espécie de racionalidade, tradutora da singularidade cultural não só de Moçambique, mas também de África.

Esse universo criativo é o lugar escolhido pelo autor para enlaçar tradição e modernidade e sobre elas refletir. Como explica em Pensatempos ${ }^{334}$ :

Deixámos de escutar as vozes que são diferentes, os silêncios que são diversos. E deixámos de escutar não porque nos rodeasse o silêncio. Ficámos surdos pelo excesso de palavras, ficámos autistas pelo excesso de informação. A natureza converteu-se em retórica, num emblema, num anúncio de televisão. Falamos dela, não a vivemos. A natureza, ela própria, tem que voltar a nascer.

Essa reflexão sobre a modernidade, na sua tendência de rasurar as vozes e silenciar os cantos da natureza, leva-o no encalço de resgatar as formas tradicionais da narração, reveladoras da experiência e enraizadas na escuta.

Sabe-se que a escuta tem caráter gregário, porque pressupõe um que fala e outro que ouve. A oralidade implica condição daquilo que em nós se orienta diretamente para outrem. Falar é se oferecer ao outro; escutar é receber, acolher, abrir-se ao diferente. Os dois movimentos, falar e receber, constituem duas formas de se unir ao outro, conforme Hindenoch ${ }^{335}$, possibilitando, assim, reafirmarem-se os laços comunitários, próprios das sociedades tradicionais. Do sentido da escuta provém a característica do agregar, do unir, do construir o espírito de comunidade.

\footnotetext{
${ }^{334}$ COUTO, Mia. Pensatempos: textos de opinião. 2.ed., Lisboa, Editorial Caminho, 2005. p.123.

335 HINDENOCH apud MATOS, Gyslaine A. A palavra do contador de histórias. São Paulo, Martins Fontes, 2005. p. 75.
} 
Amadou Hampâte $\mathrm{Ba}^{336}$ costumava dizer que "na África é contando histórias que se constrói a aldeia". Nesse intercâmbio, recupera-se a capacidade de dar conselhos, e o conselho, "tecido na substância viva da existência, tem um nome: sabedoria"337. Evidente que essa sabedoria aparece, em Mia Couto, alinhavada em livro, portanto a marca artesanal da narração não se perde, é resgatada por um novo contador, capaz de recuperar o aquele tempo em que o tempo não contava. Ao resgatar a sabedoria e a tradição, torna-se possível harmonizar o mundo moderno da informação com o mundo sensível dos cantos dos homens e da natureza.

Para tanto, vale lembrar o fragmento do romance $A$ Varanda do Frangipani:

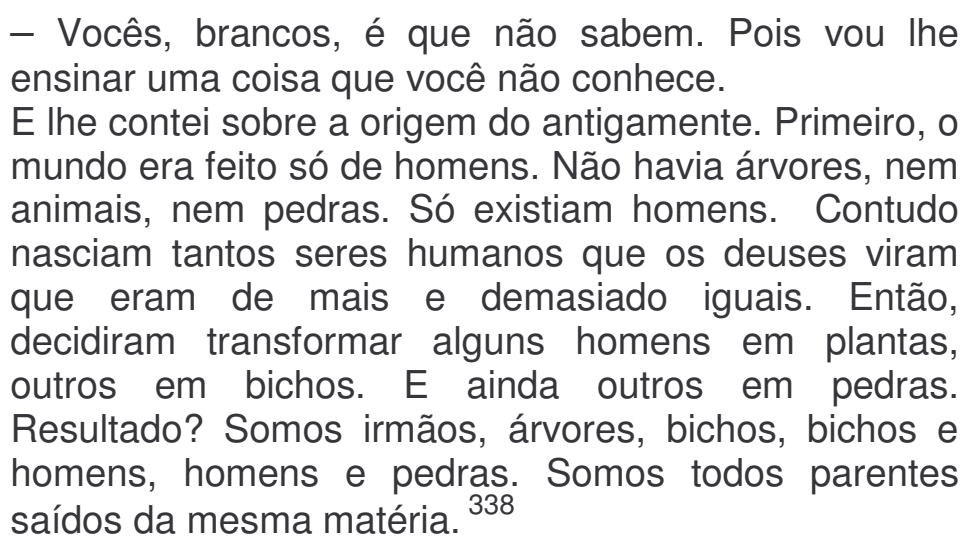

A reinauguração do mito, como forma da tradição, no gênero racionalizado do romance, como se observa acima, é a alternativa escolhida pelo autor para invocar a matéria de que se faz o homem: a natureza - algo esquecido pelo dessacralizado "homem branco" da modernidade. Se a racionalidade legitimada pelos tempos modernos e pelo mundo ocidental foi capaz de cindir Homem e Natureza, a literatura de Mia Couto apresenta-se reconciliando esses elementos substanciais para o equilíbrio humano.

Ao religar homem e natureza, religa, também, homem e sagrado, pois para as sociedades tradicionais e religiosas, no dizer de Mircea Eliade ${ }^{339}$, a natureza nunca é exclusivamente natural, está sempre carregada de um valor religioso. Por ser o

\footnotetext{
${ }^{336}$ HAMPÂTE BA apud MATOS, Gislayne Avelar. A palavra do contador de histórias: sua dimensão educativa na contemporaneidade. São Paulo, Martins Fontes, 2005. p.79.

${ }^{337}$ BENJAMIN, Walter. Obras escolhidas: magia, técnica, arte e política.v.1. Trad. Paulo Rouanet, São Paulo, Brasiliense, 1994. p.200.

${ }^{338}$ COUTO, Mia. A varanda do frangipani. 7.ed., Lisboa, Editorial Caminho, 2003. p.69.

339 ELIADE, Mircea. O sagrado e o profano: a essência das religiões. Trad. Rogério Fernandes. Lisboa, Edição Livros do Brasil.s.d. p.127.
} 
Cosmos criação dos deuses, o mundo torna-se fertilizado por essa sacralidade. Assim, coloca-se à mostra a cosmovisão do moçambicano, em especial do que vive no meio rural, para o qual não existe fronteira entre o natural e o sobrenatural, dando a conhecer uma outra forma de estar no mundo diferenciada da que se erige no mundo ocidental moderno, fundada por uma maneira dual de pensamento. Não se quer significar com isso a necessidade de enxergar a África como o paraíso perdido, nem o progresso advindo com a modernidade exclusivamente como destruidor.

Com uma literatura que acorda, diretamente, os órgãos dos sentir, Mia Couto leva-nos a um pensar sensível. Com um olhar atento, deflagrador de múltiplas formas do questionar, liberta seu ouvido de rara sensibilidade, em compasso com todos os outros órgãos dos sentidos, construindo uma narrativa musical capaz de reinaugurar a escuta.

Seu convite faz-nos ouvir atentamente, com consciência, não só a voz da natureza, mas também a voz dos ancestrais, assim como ouve o velho Sulplício em O último vôo do flamingo:

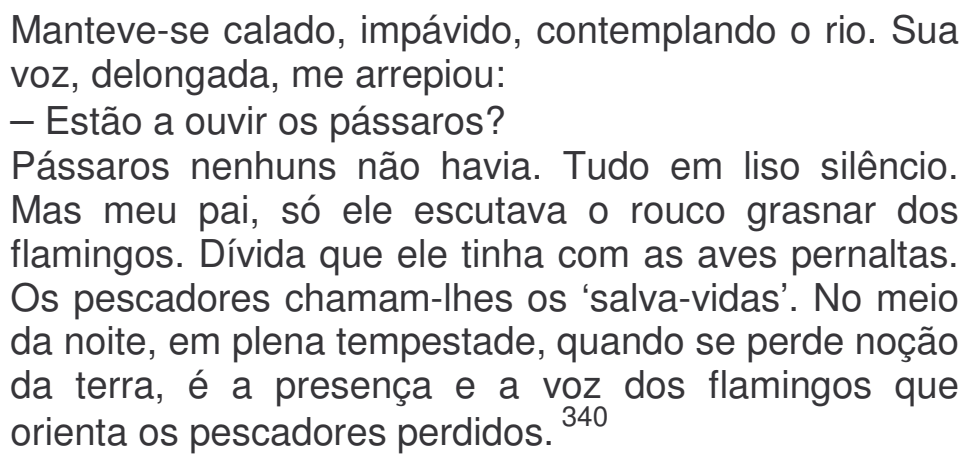

O flamingo é considerado como iniciador à luz, símbolo da alma migrante ${ }^{341}$. Ao ouvir o som desse grande pássaro rosado, ouve-se, igualmente, uma orientação para a vida. É no ressoar das vozes, tanto dos ancestrais quanto da natureza, capazes de imantar todos os outros sentidos, que se tornará possível reinventar a terra africana.

Curiosa é a seleção de contos do livro Estórias Abensonhadas ${ }^{342}$, nos quais, além da audição (em "O padre surdo", por exemplo), o autor sugere a apreensão do

\footnotetext{
${ }^{340}$ COUTO, Mia. O último voo do flamingo. São Paulo, Cia das Letras, 2005. p.132.

${ }^{341}$ CHEVALIER, Jean et GHEERBRANT, Allain. Dicionário de símbolos: mitos, sonhos, costumes, gestos, formas, figuras, cores, números. Trad. Vera da Costa e Silva et al. 10. ed., Rio de Janeiro, José Olympio, 1996.

${ }^{342}$ COUTO, Mia. Estórias Abensonhadas. 2.ed., Lisboa, Editorial Caminho, 1998.
} 
mundo por meio dos outros órgãos do sentir: a visão, em "O cego Estrelinho", "O adivinhador das mortes" ou "O Adeus da sombra"; o olfato, em "As flores da novidade", "O perfume" ou "A praça dos deuses"; o tato, em "Os infelizes cálculos da felicidade". Com isso, recupera formas de conhecer primeiras do homem, válidas e valorizadas, sobretudo nas culturas tradicionais, como as africanas.

Fundadas na tradição oral, essas culturas são reconhecidas por uma produção artesanal de suas estórias. O olho está subordinado ao ouvido. É a audição que orienta as experiências. A palavra do contador, portanto, tem força de ofício. Sua arte de narrar, como ensina Walter Benjamin ${ }^{343}$, reúne experiência, trabalho artesanal e senso prático. O narrador colhe o que narra na experiência própria ou contada e transforma isso novamente em experiência daqueles que ouvem a estória. Cumpre ressaltar que, nas sociedades tradicionais, a experiência narrada sempre se relaciona com o coletivo (erfahrung), estando inscrita em uma temporalidade comum, implicando uma tradição compartilhada e não individual (erlebnis=vivência). Por isso, sua base é a memória. O senso prático caracteriza-se pelo grau de utilidade das narrativas, no sentido de trazerem uma indicação prática, um ditado, uma norma de vida, fazendo com que o contador seja alguém apto a dar conselhos.

Nesse modelo de cultura oral, o conhecimento é repetido para não se perder. Daí a importância dos velhos, portadores da memória e transmissores dessas experiências dos tempos remotos, - e dos novos, capazes de recolher e reanimálas. As pessoas aprendem ouvindo e repetindo o que ouvem, movidas pela prática.

Fazer ressoar a voz do narrador anônimo de modo tão audível na letra do narrador contemporâneo é, no mínimo, valorizar a origem, reviver um tempo de criação e de escuta, nomear o homem comungado com o sagrado.

Ao mesmo tempo, o autor africano empresta a letra para soar outras vozes: vozes de brancos, de negros, de animais, de homens, vozes sem corpo, como as vozes dos mortos, vozes de outro mundo, vozes que emanam das profundezas da terra, vozes conhecidas e desconhecidas. Ao reunir vozes anônimas com vozes reconhecidas - brilhantemente resumidas pela expressão "autores ilegíveis", como

\footnotetext{
${ }^{343}$ BENJAMIN, Walter. Obras escolhidas: magia, técnica, arte e política.v.1. Trad. Paulo Rouanet.
} São Paulo, Brasiliense, 1994. p.60. 
anuncia em Contos do nascer da terra ${ }^{344}$ - atualiza seu plano estético e político de costurar tradição e modernidade, valorizando as identidades.

Fazendo ouvir a voz da tradição, Mia Couto tenta recuperar uma interação presencial e afetiva, projetando entre narrador e leitor a 'performance', tal como propõe Paul Zumthor ${ }^{345}$, e se observa na passagem: "eu sei, estou enchendo de saliva sua escrita. Mas, no fim, o senhor vai entender isto que estou para aqui gargantear." ${ }^{346}$. Tornando o corpo presente na escrita, fazendo conviver palavra-voz com palavra-letra, Mia Couto transforma seu texto em uma nova oportunidade para "o gesto vocal" 347 .

O momento da 'performance', em concordância com Paul Zumthor ${ }^{348}$, é único e distinto do cotidiano: "As vozes cotidianas dispersam as palavras no leito do tempo, ali esmigalham o real; a voz poética os [intérpretes] reúne num instante único - o da 'performance' [...]". Como instante único e inscrito na dimensão não cotidiana, portanto extraordinária, a 'performance' pode ser compreendida como instante sagrado.

A busca de resgatá-la implica a necessidade de inscrever e valorizar o sagrado da voz no território da letra.

O predomínio da narração sobre a descrição, bem como o uso do discurso direto e do indireto livre, mais que o indireto, ressaltam a intencionalidade de criar um território textual fronteiriço: de um lado, rompe com o estatuto do discurso monológico da tradição, visto que registra múltiplas vozes; de outro, reforça a expressão performática tradicional, reanimando os movimentos do corpo, do olho e da mão.

Com um de seus pés na oralidade e o outro na escrita, Mia Couto costura o tradicional no moderno, resgatando, na letra, os gestos e as vozes da experiência, intertextualizando lendas, mitos, provérbios, adivinhas, entre outros, reinventando, assim, as formas simples nas formas artísticas.

\footnotetext{
${ }^{344}$ COUTO, Mia. Contos do nascer da terra. 6.ed., Lisboa, Editorial Caminho, 2006. p. 229.

${ }^{345}$ ZUMTHOR, Paul. A letra e a voz: a "literatura" medieval. Trad. Amálio Pinheiro e Jerusa Pires Ferreira. São Paulo, Companhia das Letras, 1993.

${ }^{346}$ COUTO, Mia. A varanda do frangipani. 7. ed., Lisboa, Editorial Caminho, 2003. p.29.

${ }^{347}$ ZUMTHOR, Paul. A letra e a voz: a "literatura" medieval. Trad. Amálio Pinheiro e Jerusa Pires Ferreira. São Paulo, Companhia das Letras, 1993. p.55.

${ }^{348}$ Idem, ibidem. p.139.
} 
Para Andre Jolles ${ }^{349}$ :

[...] sempre que uma disposição mental leva a multiplicidade e a diversidade do ser e dos acontecimentos a cristalizarem para assumir uma certa configuração; sempre que tal diversidade, apreendida pela linguagem em seus elementos primordiais e indivisíveis e convertida em produção lingüística, possa ao mesmo tempo querer dizer e significar o ser e o acontecimento, diremos que se deu o nascimento de uma Forma Simples.

Entre essas formas não apreendidas pela estilística, nem pela retórica, nem pela poética, nem mesmo pela escrita, que não se convertem em obra de arte, embora sejam arte, na visão do referido autor, destacaremos os ditados, ou provérbios, dada a maneira reiterada como se reapresentam nas obras de Mia Couto.

A Locução, no entendimento do referido teórico, é a forma simples que se atualiza em provérbios ou ditados, como uma "espécie de afirmação ou apodíctica [...] que permite exprimir aquilo a que chamamos a experiência" ${ }^{350}$. Não se trata de uma lição, mas de algo que se concluiu com base no vivido e passou a ser compartilhado pelo grupo.

Condensando a memória da oralidade e da tradição, os provérbios apresentam-se, na produção escrita de Mia Couto, de maneira reinventada, ou parodiada, como Forma Literária, o que pode ser observado em: "preparado para o que desse e não viesse" ${ }^{351}$; "nenhuma cabeça, nenhuma sentença"352; "E contra factos tudo são argumentos." 353 , entre tantos outros. Novamente, constatamos, nessa apropriação, uma tentativa do autor em enlaçar a tradição na modernidade.

Como "ideogramas de uma narrativa", ou como "ruínas de antigas narrativas", no entender de Walter Benjamin ${ }^{354}$, os provérbios, ao mesmo tempo em que afirmam o poder da voz antiga diante da força destruidora da letra, reinventam tradição,

\footnotetext{
${ }^{349}$ JOLLES, André. Formas Simples: legenda, saga, mito, adivinha, ditado, caso, memorável, conto, chiste. Trad. Álvaro Cabral. São Paulo, Cultrix, 1976. p.46.

${ }^{350}$ Idem, ibidem. p. 132.

${ }^{351}$ COUTO, Mia. Um rio chamado tempo, uma casa chamada terra. São Paulo, Companhia das Letras, 2003. p.60.

${ }^{352}$ COUTO, Mia. A chuva pasmada. Lisboa, Editorial Caminho, 2004. p.11.

${ }^{353}$ COUTO, Mia. O último voo do flamingo. São Paulo, Cia das Letras, 2005. p.15.

${ }^{354}$ BENJAMIN, Walter. Obras escolhidas: magia, técnica, arte e política.v.1. Trad. Paulo Rouanet. São Paulo, Brasiliense, 1994. p.221.
} 
muitas vezes, ao revés, na tentativa de restabelecer, de maneira imprevista, a experiência do passado: o provérbio torna-se improvérbio.

Esse apreço por uma forma sintética de sabedoria popular, apresentada às avessas, serve de recurso para questionar verdades estabelecidas pela repetição. Espelhando-se vitalizadas, as formas antigas e conformadoras ganham, na obra do moçambicano, tom de inquietação. Em consonância com Rita Chaves ${ }^{355}$, "se num mundo movido pelo dinamismo das mudanças sociais, o provérbio pode ser encarado como uma expressão de conformismo, num universo calcado na imobilidade e na exclusão, a fala popular ganha tons de subversão". Ao reformar o provérbio, Mia Couto desconstrói, sobrepondo uma nova forma à velha. O que poderia ser resíduo da oralidade passa a ser, na escrita, semente de um novo a se construir no presente.

É clara a preocupação do escritor moçambicano em operar com esses ditados, não apenas para fixar, na memória, a experiência vivida, mas também para subvertê-la, para transformá-la. Esse jogo insubordinado, do qual o leitor deve capturar o sentido, é feito, igualmente, com as orações cristãs, as ladainhas, como: "Pai nosso, cristais no Céu, santo e ficado seja o vosso nome"356; "[...]graças e desgraças a Deus." 357 ; "estou escrevendo torto por linhas direitas"358; "- Lavado seja Deus!"359; entre outros. Essa é a forma pela qual Mia Couto coloca fluidez no discurso estagnado, movimento no discurso em repouso, estabelecendo diálogo crítico com a cultura do colonizador.

Sua palavra desenraiza-se da cultura colonizadora de origem e torna-se capaz de nomear a diferença, mostrando uma potência que convoca a um novo enraizar. Nomeia-se, dessa forma, essa nova cultura, há muito rasurada, silenciada, abandonada ao olhar hegemônico, porque sustentada pela oralidade. Na confissão e primeiro escrito do administrador, em O último vôo do flamingo, lê-se: "Não sou um lembrador. Minha única dificuldade é ter que escrever por escrito" ${ }^{360}$, ou, nas cartas que Mariano misteriosamente recebia, em Um rio chamado tempo, uma casa

\footnotetext{
${ }^{355}$ CHAVES, Rita. In: Revista Via Atlântica. n.3. São Paulo, Departamento de Letras Clássicas e Vernáculas, Faculdade de Filosofia, Letras e Ciências Humanas, Universidade de São Paulo, 1999. p.160.

${ }^{356}$ COUTO, Mia. A chuva pasmada. Lisboa, Editorial Caminho, 2004. p.20.

${ }^{357}$ COUTO, Mia. Il. João Nasi Pereira. Mar me quer. 5.ed., Lisboa, Editorial Caminho, 2000. p.23.

${ }^{358}$ COUTO, Mia. O último voo do flamingo. São Paulo, Cia das Letras, 2005. p.171.

${ }^{359}$ COUTO, Mia. A chuva pasmada. Lisboa, Editorial Caminho, 2004. p.72.

${ }^{360}$ COUTO, Mia. O último voo do flamingo. São Paulo, Cia das Letras, 2005. p.71.
} 
chamada terra, em que se narra: "Estas cartas, Mariano, não são escritos. São falas. Sente-se, se deixe em bastante sossego e escute" ${ }^{361}$.

Ecoando a oralidade nas fissuras da letra, Mia Couto opta por enredar tradição e modernidade, transformando suas criações estéticas em tessituras de contigüidade, em que se avizinham 'falescrita' ou 'oralitura'.

Nesse projeto, trabalha a língua com todos os mecanismos disponíveis para criar. Subverte a norma-padrão do português europeu, ao adotar inovações lexicais, por meio desse processo inventivo que se observa em uma quantidade significativa de neologismos, como: "o rio se reviravirasse"362. "Luarmina costureirava"363; "já se antigamentara"364; "o homem andava que tresandava"365; "labirintoar"366.; "nenhumarias"367; "ruássemos por ali, desmapeados e sem destino"368; "rapidandose"369. "era um homem que se entregava aos outros, capaz de outroísmos"370; anteriu $^{371}$; entre muitos outros. Valendo-se de procedimentos como a derivação sufixal, prefixal, imprópria, vai transformando os signos lingüísticos, mudando categorias gramaticais, atualizando sentidos outros, fazendo com que a língua assuma novo semblante, na perspectiva sempre presente de exprimir e sonhar conteúdos novos.

Em nenhum momento, Mia Couto nega sua admiração e proximidade artística com o brasileiro Guimarães Rosa em sua tarefa de forjar na língua a reinvenção desejada para a realidade.

Nessa perspectiva de transpor os ruídos da oralidade nas marcas da letra, traduzindo sons naturais, como forma de preservar referenciais autóctones, o autor faz uso de onomatopéias, como: "o pau cortava o ar, vuááááá"372. "entreguei uns terrenos, tudo tu-cá-dá-lá”" ${ }^{373}$; "Rebentou-se no chão, as peças tin-tin-tin no pátio”374;

${ }^{361}$ COUTO, Mia. Um rio chamado tempo, uma casa chamada terra. São Paulo, Companhia das Letras, 2003. p.64.

${ }^{362}$ Idem, ibidem. p. 18.

${ }^{363}$ COUTO, Mia. . Il. João Nasi Pereira. Mar me quer. 5.ed., Lisboa, Editorial Caminho, 2000. p.10.

${ }^{364}$ Idem, ibidem. p. 10.

${ }^{365}$ Idem, ibidem. p. 41.

${ }^{366}$ COUTO, Mia. O último voo do flamingo. São Paulo, Cia das Letras, 2005. p.17.

${ }^{367}$ Idem, ibidem. p. 29.

${ }^{368}$ Idem, ibidem. p. 101.

${ }^{369}$ Idem, ibidem. p. 159.

${ }^{370}$ Idem, ibidem. p. 160.

${ }^{371}$ COUTO, Mia. Vozes Anoitecidas. 8.ed., Lisboa, Editorial Caminho, 1987. p.62.

${ }^{372}$ COUTO, Mia. O último voo do flamingo. São Paulo, Cia das Letras, 2005. p.187.

${ }^{373}$ Idem, ibidem. p. 96.

${ }^{374}$ COUTO, Mia. Vozes Anoitecidas. 8.ed., Lisboa, Editorial Caminho, 1987. p.62. 
"Vai campainhando, trim-trim-trim"375; "zunzunando sobre as explosões"376; "O motor nhenhenhou-se" 377 . Apresentam-se tanto onomatopéias de caráter acidental quanto lexicadas, dotadas de comportamento sintático. São reproduzidos ora sons momentâneos - oferecendo ao leitor o máximo de sugestão -, ora sons convencionados, integrados ao sistema fônico da língua, conferindo mais vivacidade, concretude e ritmo ao narrado.

Compondo-se com essa "harmonia imitativa", como nos ensina Nilce Sant' Anna Martins ${ }^{378}$, a escrita musical de Mia Couto vai assumindo, cada vez mais, a feição dessa cultura que se faz pelo ouvido, em canto, arquitetando-se, esteticamente, em mosaico de letras, fonemas e sentidos a se tangenciarem pela sonoridade e pelo ritmo.

O autor não hesita em acariciar a língua com suas imprevisíveis "brincriações", como se nota em: "sou um aparente parente"379, "mais sedento que sedentário"380; "não se ocupe nem se preocupe"381; "sem consciência nem consistência"382; "o hóspede que pousasse as malas e a alma"383; "Cheia de poses e posses"384; "Vozes e vultos correndo das palhotas"385. É por essa atitude que Mia Couto nos devolve, sobretudo na prosa, os ritmos da própria poesia, em jogo de letras e sons, aliterações, trocadilhos, anagramas, conferindo harmonia, riqueza afetiva e expressividade às suas construções estéticas.

Ainda na perspectiva de musicalizar a letra, com os antigos movimentos da voz e do corpo, o autor opera com a repetição, reinaugurando, poeticamente, a oralidade: "acorreram a recolher a recolher o ressurgido"386.

Nesse mesmo itinerário de enlevar o leitor ao reino estético, cria expressões de rara beleza, como uma sensível combinação de substantivos concretos e

${ }^{375}$ COUTO, Mia. Vozes Anoitecidas. 8.ed., Lisboa, Editorial Caminho, 1987. p.66.

${ }^{376}$ COUTO, Mia. O último voo do flamingo. São Paulo, Cia das Letras, 2005. p.95.

${ }^{377}$ Idem, ibidem. p.31.

${ }^{378}$ MARTINS, Nilce Sant'Anna. Introdução à Estilística: a expressividade na língua portuguesa. 2.ed., São Paulo, T.A. Editor, 1997. p.50.

${ }^{379}$ COUTO, Mia. Um rio chamado tempo, uma casa chamada terra. São Paulo, Companhia das Letras, 2003. p.30.

${ }^{380}$ Idem, ibidem. p.42.

${ }^{381}$ Idem, ibidem. p. 198.

${ }^{382}$ COUTO, Mia. O último voo do flamingo. São Paulo, Cia das Letras, 2005. p.94.

${ }^{383}$ Idem, ibidem. p.36.

${ }^{384}$ Idem, ibidem. p. 107.

385 COUTO, Mia. Um rio chamado tempo, uma casa chamada terra. São Paulo, Companhia das Letras, 2003. p.65.

${ }^{386}$ COUTO, Mia. Il. João Nasi Pereira. Mar me quer. 5.ed., Lisboa, Editorial Caminho, 2000. p.28. 
abstratos, tão recorrente em seus textos: "pareciam feitos apenas para passarem sonhos e poentes"387; "penetrei pelo escuro de gasolina, raiva e fósforo"388. Esse cruzamento original, porque inesperado, do concreto com o abstrato, metaforiza duas experiências distintas de estar no mundo: uma característica da cultura oral sustentada pelo pensamento concreto, outra característica da cultura escrita apoiada pelo pensamento abstrato.

Às vezes, escritor africano acrescenta, nessas combinações estilísticas, o recurso da gradação, oferecendo ao leitor uma língua outra, marcada, expressivamente, pela possibilidade de reinvenção, como se observa em: "Contaram-se segundos, minutos, lágrimas, suspiros". 389

O escritor faz questão de nos apresentar a língua portuguesa como um sistema aberto e, ao mesmo tempo, afetivo, empregando, com reconhecida singularidade, uma linguagem extremamente impressiva, obtida, por exemplo, com a alternância do adjetivo com o substantivo, "no abafado do quarto"390; com a troca da classe gramatical das palavras, como "no antigamente"391; "Não havia sinal dele, apenas dicências, istos-aquilos"392; "ficamos ali horas trocando nadas"393. Ou quando rompe com as regras da sintaxe para subverter a cultura que as impõe, como em: "Lhe fazia falta, sim, o azul."394;"ela tenta brincar-me"”395; "Venha dançarme,sobrinho! ${ }^{396} ;$ "Afinal, Carlota Gentina não chegou de voar?" (título de um conto de Vozes Anoitecidas ${ }^{397}$ ). Ou, ainda, quando opta por causar estranhamento com construções sintáticas reveladoras de sua mundivisão, não só tocando questões atinentes à realidade histórico-política, mas também atingindo o sentido universal de que a toda arte se nutre:

\footnotetext{
${ }^{387}$ COUTO, Mia. O último voo do flamingo. São Paulo, Cia das Letras, 2005. p.52.

${ }^{388}$ COUTO, Mia. Il. João Nasi Pereira. Mar me quer. 5.ed., Lisboa, Editorial Caminho, 2000. p.50.

${ }^{389}$ Idem, ibidem. p. 28.

${ }^{390}$ COUTO, Mia. Um rio chamado tempo, uma casa chamada terra. São Paulo, Companhia das Letras, 2003. p.34.

${ }^{391}$ COUTO, Mia. Il. João Nasi Pereira. Mar me quer. 5.ed., Lisboa, Editorial Caminho, 2000. p.36.

${ }^{392}$ COUTO, Mia. O último voo do flamingo. São Paulo, Cia das Letras, 2005. p.52.

${ }^{393}$ Idem, ibidem. p. 113.

${ }^{394}$ COUTO, Mia. Um rio chamado tempo, uma casa chamada terra. São Paulo, Companhia das Letras, 2003. p.20.

${ }^{395}$ COUTO, Mia. Il. João Nasi Pereira. Mar me quer. 5.ed., Lisboa, Editorial Caminho, 2000. p.12.

${ }^{396}$ COUTO, Mia. A chuva pasmada. Lisboa, Editorial Caminho, 2004. p.23.

${ }^{397}$ COUTO, Mia. Vozes Anoitecidas. 8.ed., Lisboa, Editorial Caminho, 1987. p.73.
} 
Eu somos tristes. Não me engano, digo bem. Ou talvez: nós sou triste? Porque dentro de mim, não sou sozinho, sou muitos. E esses todos disputam minha única vida. Vamos tendo nossas mortes. Mas parto foi só um. Aí o problema. Por isso, quando conto minha história me misturo, mulato não das raças, mas de existências. ${ }^{398}$

O uso da primeira pessoa do singular, em concordância com o verbo na primeira do plural - "Eu somos triste" - ou da primeira do plural, concordando com o verbo no singular - "nós sou triste" - em silepse de pessoa, mostra a preocupação do autor em apresentar as múltiplas identidades que compõem o homem moçambicano. Essa é a maneira que o escritor encontra para contar, na forma literária, o que experimenta no contexto histórico em que vive. E muito mais do que isso, ao criar essa mistura de identidades e de existências, amplia a possibilidade de adesão do leitor, que ali se projeta, fazendo de sua travessia imaginária uma oportunidade de leitura de si mesmo.

Por meio das subversões morfológicas, sintáticas e semânticas, Mia Couto cria diálogos entre a vida vivida e a vida sonhada, aproximando tradição oral de tradição literária.

O lirismo que acompanha seus escritos em prosa tinge-a de poeticidade, pela habilidade com que faz uso de figuras de linguagem, como a sinestesia, cruzando, de maneira paradoxal, algumas sensações, como em: "ouço luz da água"399, "ouviu as visões com atenção"400; "seu olhar parece mais um modo de escutar"401.

Comparações e metáforas tornam suas narrativas substancialmente mais afetivas, levando o leitor a trilhar caminhos em que associa o maravilhoso da sensibilidade e o da própria linguagem, como se observa em: "Aquele era um tempo sem guerra, sem morte. A terra estava aberta a futuros, como uma folha branca em mão de criança." ${ }^{402}$; "na nossa terra, o sofrimento é uma nudez - não se mostra aos públicos"403";mais afiada que lâmina a vida decepara os laços dos nossos destinos.

\footnotetext{
${ }^{398}$ COUTO, Mia. Vozes Anoitecidas. 8.ed., Lisboa, Editorial Caminho, 1987. p.75.

${ }^{399}$ COUTO, Mia. Il. João Nasi Pereira. Mar me quer. 5.ed., Lisboa, Editorial Caminho, 2000. p.62.

${ }^{400}$ COUTO, Mia. Vozes Anoitecidas. 8.ed., Lisboa, Editorial Caminho, 1987. p.146.

${ }^{401}$ COUTO, Mia. Um rio chamado tempo, uma casa chamada terra. São Paulo, Companhia das Letras, 2003. p.19.

${ }^{402}$ Idem, ibidem. p.43.

${ }^{403}$ Idem, ibidem. p. 19.
} 
O tempo, depois, tem ilusão de costureiro." "404."A chuva é uma mulher. Uma dessas viúvas de vaidade envergonhada: tem um vestido de sete cores mas só veste nos

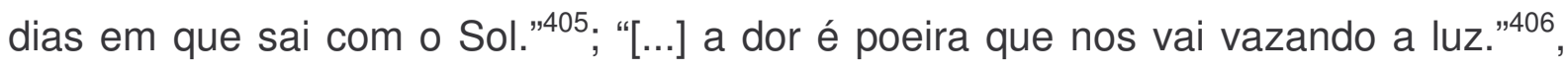
entre tantas outras.

Além da metáfora, a personificação também é figura bastante utilizada pelo autor, convocando o ouvinte-leitor a compartilhar de uma forma de conhecimento de mundo inaceitável pela racionalidade ocidental moderna, mas muito característica da cultura tradicional: o conhecimento mágico, como se nota em. "O rio estava tristonho que ela nunca vira." ${ }^{407 ; " A ~ i n d e c i s a ̃ o ~ d a ~ c h u v a ~ n a ̃ o ~ e r a ~ m o t i v o ~ p a r a ~ a l e g r i a ” 408 ~ ; " a ~}$ água acorria a me buscar, sua língua azul me vinha arrancar deste mundo."409

A opção por recursos literários renovadores da dimensão afetiva própria do conhecimento mágico favorece a aproximação dessa literatura com a criança. Aliás, é recorrente, na obra de Mia Couto, a associação de palavras para compor outras, instaurando o lúdico característico da linguagem infantil. O título do livro Estórias Abensonhadas mostra essa linguagem no limiar entre a bênção e o sonho; a palavra traumartirizado" 410 - que funde trauma e martirizado, ampliando e intensificando o sentimento -, ou ainda "miraginava terras e territórios" 411 - em que a realidade de mirar e o sonho de descobrir novas terras não são ações díspares, mas simultâneas, ou seja, criando uma imagem que sintetiza sonho e realidade -; além de outras tantas, como "agradádiva"412; pedinchorar ${ }^{413}$ - acabam por instaurar, na superfície do texto, a possibilidade de brincar, ou de "brincriar" com a língua, compreendendo-a como forma de expressar, magicamente, uma realidade também experimentada como mágica .

Entretanto, não é apenas essa dimensão mágica a focalizada pelo autor, pois, em sua perspectiva sempre de fronteira, em trânsito de mundos, é coerente explorar

${ }^{404}$ COUTO, Mia. Um rio chamado tempo, uma casa chamada terra. São Paulo, Companhia das Letras, 2003. p.136.

${ }^{405}$ COUTO, Mia. A chuva pasmada. Lisboa, Editorial Caminho, 2004. p.7.

${ }^{406}$ COUTO, Mia. Vozes Anoitecidas. 8.ed., Lisboa, Editorial Caminho, 1987. p.52.

${ }^{407}$ COUTO, Mia. Um rio chamado tempo, uma casa chamada terra. São Paulo, Companhia das Letras, 2003. p.21.

${ }^{408}$ COUTO, Mia. A chuva pasmada. Lisboa, Editorial Caminho, 2004. p.7.

${ }^{409}$ COUTO, Mia. Il. João Nasi Pereira. Mar me quer. 5.ed., Lisboa, Editorial Caminho, 2000. p.59.

${ }^{410}$ COUTO, Mia. Um rio chamado tempo, uma casa chamada terra. São Paulo, Companhia das Letras, 2003. p.214.

${ }^{411}$ COUTO, Mia. Estórias Abensonhadas. 2.ed., Lisboa, Editorial Caminho, 1998. p.26.

${ }^{412}$ COUTO, Mia. Il. João Nasi Pereira. Mar me quer. 5.ed., Lisboa, Editorial Caminho, 2000. p.51.

${ }^{413}$ COUTO, Mia. Estórias Abensonhadas. 2.ed., Lisboa, Editorial Caminho, 1998. p.74. 
desde 0 aspecto afetivo e simples ${ }^{414}$ da linguagem infantil até o aspecto conceitual e abstrato da linguagem do adulto. Ao mesmo tempo em que trabalha com o lúdico como se observa, por exemplo, no título de um capítulo do livro A chuva pasmada: "O peixar do tempo"415 - transborda para o filosófico: "Pescar é um modo de ser peixe nas águas do tempo"416, ou então, "na aldeiazinha onde crescera, o rio tinha sido o céu da sua infância. No fundo, porém, o azul nunca é uma cor exacta. Apenas uma lembrança, em nós, da água que já fomos." ${ }^{417}$. Dessa forma, esse reconhecido autor africano convida o leitor a um duplo exercício: ao jogo estético e, ao mesmo tempo, reflexivo.

Dessa maneira, Mia Couto vai concedendo ao leitor a possibilidade de viver experiências que alinhavam formas distintas de perceber a realidade e de pensá-la.

No limite entre o infantil e o adulto, entre o concreto e o abstrato, entre a moral da estória e as indagações sobre o sentido da vida, no entretempo construído pela convergência da tradição e da modernidade, o escritor faz vislumbrar um entrelugar estético em que se trançam os fios do sagrado.

Com essa literatura que faz regressar os alinhavos da voz pelas bordas da letra, Mia Couto ${ }^{418}$ realiza seu projeto estético e político, apresentando sua proposta de que, para que o mundo seja salvo, é necessário ele nascer em nós como outro mundo e, ao mesmo tempo, nós nele nascermos, como afirma em Pensatempos.

É com essa intenção que desenha, nas franjas do verbo, uma nova cosmogonia, entretecida pela idéia de que "o que um escritor nos dá não são livros. O que ele nos dá, por via da escrita, é um mundo"419, um mundo que se plasma, imaginariamente, pelo sêmen de uma nova linguagem artística, engravidada por uma língua já velha, mas, que por estar em estado de festa, é capaz de renovar a letra pelo sopro sacralizado da voz. Nesse contexto, a palavra, em estado de

${ }^{414}$ Importante ressaltar que não se pode confundir simplicidade com facilidade. Grandes idéias são idéias simples, óbvias, mas poucos são os que desenvolvem a observação sensível para descobrilas. Simplificar exige operações complexas. Como ensina Drummond: "o belo é simples por depuração", ou seja, é um trabalho de descarnar algo até chegar ao cerne, à essência. E toda essência é simples. Essa tarefa pressupõe, portanto, obstáculos e sua superação. A facilidade é característica do que se faz sem dificuldade, sem obstáculos. A simplicidade é característica positiva da literatura; a facilidade, não.

${ }^{415}$ COUTO, Mia. A chuva pasmada. Lisboa, Editorial Caminho, 2004. p.35.

${ }^{416}$ Idem, ibidem. p.35.

${ }^{417}$ COUTO, Mia. Um rio chamado tempo, uma casa chamada terra. São Paulo, Companhia das Letras, 2003. p.20.

${ }^{418}$ COUTO, Mia. Pensatempos: textos de opinião. 2.ed., Lisboa, Editorial Caminho, 2005. p.120.

${ }^{419}$ Idem, ibidem. p.110. 
absoluta prenhez, pela letra que tudo eterniza, ganha, no corpo do livro, seu lugar de iniciação, tornando a leitura um exercício iniciático de re-encantamento.

Esse exercício de reencantamento realiza-se, também, graças à presença do maravilhoso. Segundo Irlemar Chiampi ${ }^{420}$, "maravilhoso é o 'extraordinário', o insólito, o que escapa ao curso ordinário das coisas e do humano. Maravilhoso é o que contém maravilha, do latim 'mirabilia', ou seja, coisas admiráveis (belas ou execráveis, boas ou horríveis), contrapostas à 'naturalia'. Em 'mirabilia', está presente o mirar: olhar com intensidade, ver com atenção, ou ainda, ver através. 0 verbo 'mirare' encontra-se, também, na etimologia de milagre”, portanto, na opção pelo maravilhoso, Mia Couto, igualmente, enreda o leitor nas malhas do sagrado.

Em Um rio chamado tempo, uma casa chamada terra, Marianinho, nascido na ilha de Luar-do-Chão, mas habitante da cidade, estudante universitário, é obrigado, pelas circunstâncias da morte do avô, a ter um novo olhar para as tradições regionais. Esse é o cenário para o confronto entre o mundo urbano, capitalista, moderno e o mundo comunitário, mítico, fundado em valores ancestrais. Mariano, no percurso de descoberta de sua comunidade e de sua própria história, transita nas confluências do natural e do sobrenatural, do profano e do sagrado. Em sua viagem iniciática, a ordem natural das coisas é suspensa por fatos insólitos, como os citados abaixo:

- O pai do protagonista possuía, na varanda, uma gaiola aberta, à espera que um pássaro entrasse voluntariamente. No final do romance, o pai lança no ar a gaiola, que, em vez de se despedaçar, converte-se em pássaro: "já toda ave, ela reganha os céus e se extingue"421.

- Quando a mãe de Mariano Neto morreu, seu corpo se desfez em água e precisaram enterrar um vaso com água do rio: "sua mãe é o rio, está correndo por aí, nessas ondas." ${ }^{422}$

- Na hora em que tentam enterrar o avô, a terra se fecha e ninguém consegue mais cavá-la.

\footnotetext{
${ }^{420}$ CHIAMPI, Irlemar. O realismo maravilhoso. São Paulo, Perspectiva, 1980. p.48.

${ }^{421}$ COUTO, Mia. Um rio chamado tempo, uma casa chamada terra. São Paulo, Companhia das Letras, 2003. p.246.

${ }^{422}$ Idem, ibidem. p.105.
} 
Em Vozes Anoitecidas, o boi Mabata-bata explode, chovem "pedaços, fatias, grãos e folhas de boi. A carne eram já borboletas vermelhas. Os ossos eram moedas espalhadas. Os chifres ficavam num qualquer ramo, balouçando a imitar vida, no invisível vento. O espanto não cabia em Azarias, o pequeno pastor."423;um homem mata uma mulher que era pássaro:"A minha mulher matei, dizem. Na vida real, matei uma que não existia. Era um pássaro. Soltei-lhe quando vi que ela não tinha voz, morria sem queixar. Que bicho saiu dela, mudo, através do intervalo do corpo?"

Essas imagens insólitas, entre tantas outras, atestam que o escriba do Índico joga na fronteira do ordinário e do extraordinário, operando no terreno do realismo maravilhoso por meio do qual reencanta, por esboçar, nas agruras da letra, o milagre da história: o sonho possível de tempos melhores. Essa possibilidade se abre para o escritor pelas margens da palavra literária, tecidas com a pena ficcional, instrumento cosmogônico, capaz de criar mundos e fazer o leitor dobrar-se em si, antes mesmo de desdobrar-se ao outro e ao mundo, enxergar suas tradições, antes mesmo de entregar-se à modernidade. Como se lê em Estórias Abensonhadas: "nós temos olhos que se abrem para dentro, esses que usamos para ver os sonhos" 425 . Esse sonho mostra-se alcançável para o autor, que, na voz do narrador de "O bebedor de tempo", na mesma obra, revela: "[...] sempre a linha do tempo traz um anzol de futuro" ${ }^{426}$.

Esse futuro está sempre em questão na obra do moçambicano. A escolha do fantástico torna-se alternativa literária salutar e compatível com a inconformação diante do desconcerto do sentido da vida, em Moçambique, provocado, historicamente, pela derrocada de seu mundo nas sucessivas guerras - de libertação e civil, que assolaram o país, e, de fato, constituíram-se como uma realidade insana e caótica. Ao valer-se do realismo maravilhoso, Mia Couto busca configurar uma imagem de mundo com menos contradições e antagonismos, para nos apropriarmos das idéias de Irlemar Chiampi ${ }^{427}$. Cumpre lembrar que esse mundo sobrenatural, inseparável da experiência ordinária, é próprio da

\footnotetext{
${ }^{423}$ COUTO, Mia. Vozes Anoitecidas. 8.ed., Lisboa, Editorial Caminho, 1987. p.43.

${ }^{424}$ Idem, ibidem. p. 75.

${ }^{425}$ COUTO, Mia. Estórias Abensonhadas. 2.ed., Lisboa, Editorial Caminho,1998. p.13.

${ }^{426}$ Idem, ibidem. p. 132.

${ }^{427}$ CHIAMPI, Irlemar. O realismo maravilhoso. São Paulo, Perspectiva, 1980. p.89.
} 
mundividência tradicional, que Mia Couto busca enlaçar em seu projeto de construção da modernidade.

A intromissão do anormal no normal, da dúvida na certeza, a quebra de uma lógica pela instauração de outra levam o leitor a questionar seu ponto de vista. Assim, a presença do fantástico e do maravilhoso revela-se profícua para fertilizar transformações. Na esteira de Tzvetan Todorov ${ }^{428}$, "o elemento maravilhoso revelase como o material narrativo que melhor preenche esta função precisa: trazer uma modificação à situação precedente e romper o equilíbrio (ou o desequilíbrio) estabelecido". E continua o autor: trata-se de uma "transgressão da lei. Quer seja no interior da vida social ou da narrativa, a intervenção do elemento sobrenatural constitui sempre uma ruptura no sistema de regras preestabelecidas e nela encontra justificação" ${ }^{429}$. Apreende-se, dessa maneira, que, se, na vida ordinária, repetimos comportamentos e isso nos parece natural, na literatura, é intencional, consciente, e isso prepara o leitor para reler sua realidade de uma forma outra, possibilitando a transformação.

O realismo maravilhoso, como opção literária, propõe um "reconhecimento inquietante", no dizer de Irlemar Chiampi ${ }^{430}$, e o faz de maneira consciente, pois o papel da mitologia, das crenças religiosas, da magia e das tradições populares fundadas no maravilhoso consiste em trazer de volta o coletivo, dissimulado pela repressão da racionalidade. Ele toca a sensibilidade do leitor como ser coletivo, como membro de uma comunidade, ou seja, restitui, portanto, a tradição.

Ao mesmo tempo em que essa modalidade narrativa problematiza a concepção racional-positivista moderna, ela põe em evidência a possibilidade de convivência do natural e do sobrenatural. Reafirma-se, com ela, a desnaturalização do real e a naturalização do maravilhoso, em outras palavras a dialética do sagrado e do profano. Isso quer dizer que o sagrado, encapsulado no maravilhoso, participa do profano. Aquilo que se constitui como matriz da cultura oral e da tradição é reconhecido como possibilidade inconteste para a afirmação e para a construção de um novo modo de estar moçambicano, de um novo homem africano - o que significa afirmar a convivência de tradição e modernidade em bases menos antagônicas.

\footnotetext{
${ }^{428}$ TODOROV, Tzvetan. Introdução à Literatura fantástica. 3.ed., São Paulo, Perspectiva, 2004. p.174.

${ }^{429}$ Idem, ibidem. p. 174.

${ }^{430}$ CHIAMPI, Irlemar. O realismo maravilhoso. São Paulo, Perspectiva, 1980.
} 
É fato que Mia Couto faz questão de registrar o modo perverso como Moçambique vem se modernizando: "Dói-me a llha como está, a decadência das casas, a miséria derramada pelas ruas. Mesmo a natureza parece sofrer de mauolhado." ${ }^{31}$; " [...] os nossos antepassados nos olham agora como filhos estranhos. E quando nos olham já não nos reconhecem."432

Não reconhecer significa não perceber os traços característicos, o que revela um processo de reificação, por isso o militante das letras faz questão de sonhar um novo paradigma em que passado, presente e futuro estabeleçam íntima convivência. Isso fica sublinhado pela forma como realiza seu projeto estético, o que, aos poucos, estamos buscando mostrar.

Para ilustrar essa convivência, cumpre citar a forma como se apresenta a morte, elemento recorrente em suas obras. Na cultura moçambicana, o mundo da ancestralidade convive com o mundo sensorial. Espíritos dos antepassados, seres que estiveram entre os viventes e que, ao passarem pela morte, não perderam sua autoridade, podem ser invocados a qualquer momento para participarem da vida comum. Recria Mia Couto ${ }^{433}$ : "Em África, os mortos não morrem nunca [...] Afinal, a morte é um outro nascimento". Para os povos de origem bantu, de Moçambique, a morte não é um fim, mas uma passagem de um mundo a outro, ao mundo dos espíritos,uma espécie de lei do eterno retorno. A morte é um novo nascimento.

Em Um rio chamado tempo, uma casa chamada terra, lê-se:

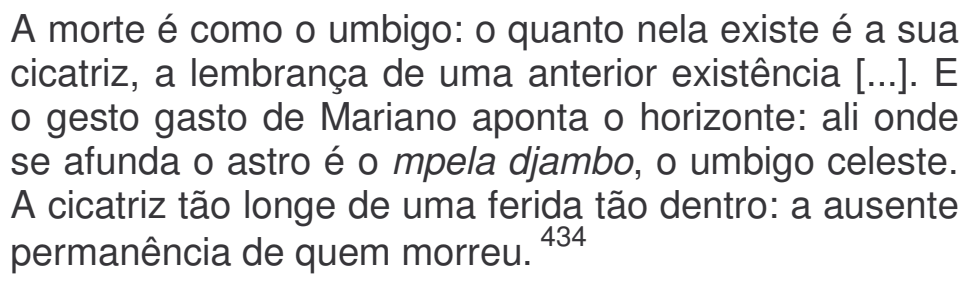

Assim, também, o autor propõe a nova sociedade moçambicana, construída na relação dialética que se funda entre a permanência e a ausência, entre a memória e o sonho, entre a morte e a nova vida, em um entrelugar no qual o passado seja catalisador do futuro: 'mpela djambo'.

\footnotetext{
${ }^{431}$ COUTO, Mia. Um rio chamado tempo, uma casa chamada terra. São Paulo, Companhia das Letras, 2003. p.28.

${ }^{432}$ COUTO, Mia. O último voo do flamingo. São Paulo, Cia das Letras, 2005. p.208.

${ }^{433}$ COUTO, Mia. Um rio chamado tempo, uma casa chamada terra. São Paulo, Companhia das Letras, 2003. p.30.

${ }^{434}$ Idem, ibidem. p. 15.
} 
A imagem de Nyumba-Kaya', nessa mesma obra, a legítima morada, casa absoluta dos vivos e dos antepassados - constitui-se uma bela lembrança de uma África originária.

Na língua de Luar-do-Chão, o morto é plantado, porque é coisa viva, está suspenso entre a vida mortal e a vida imortal. A morte configura-se como transformação. O avô mostra as duas condições de existência: "desterrado e enterrado. Como vivo, sem terra, porque é do colonizador, como morto, soterrado, é capaz de ganhar nova vida: "como se estivesse engravidando do meu próprio falecimento e sentisse a presença crescente, dentro de mim, desse feto que era a minha própria morte" ${ }^{\sharp 35}$.

Entre a vida e a morte, a voz antiga do avô-pai fala com o neto-filho. Por meio de cartas, de caligrafadas palavras, pelas mãos do próprio neto, vai desfiando estórias, fazendo-o visitar casa, terra, homem e rio. E faz questão de destacar: "Há um rio que corre dentro de nós, corre por dentro da casa e deságua não no mar, mas na terra. Esse rio uns chamam de vida. ${ }^{436} \mathrm{~A}$ vida que advirá como nova para a cultura moçambicana há de tecer-se, enraizada na terra, com os liames do passado orientando-se ao futuro. Só assim tornar-se-á possível uma nova história, um novo som no silêncio da letra, como no trecho: "É então que sucede o que não é de acreditar: a minha letra desobedece da mão que a engendra. Aquilo que estou escrevendo se transfigura em outro escrito. Uma outra carta me vai surgindo, involuntária, das minhas mãos”437.

A experiência da morte, entretecida por esse misticismo ancestral, põe à mostra a mundividência africana, enraizada no passado e catalisadora da esperança no futuro. E essa esperança, assim como Avô Mariano, não morre, permanece viva na figura de seu neto/filho Marianito.

Importante observar que a síntese desses dois mundos - passado e futuro concretiza-se nas imagens dos mais velhos e dos mais novos.

O velho é signo da sabedoria, a voz da experiência contada em estórias, como se nota em: "[...] dói-me pensar que nunca mais o escutarei contando histórias.

\footnotetext{
${ }^{435}$ COUTO, Mia. Um rio chamado tempo, uma casa chamada terra. São Paulo, Companhia das Letras, 2003. p.196.

${ }^{436}$ Idem, ibidem. p. 258.

${ }^{437}$ Idem, ibidem. p. 170.
} 
Ter um avô assim era para mim mais que um parentesco. Era um laço de orgulho nas raízes mais antigas" ${ }^{438}$.

Portador da voz das origens, da tradição oral, o velho não se coaduna com a cultura escrita, com o mundo dos livros, como se observa, por exemplo, em Um rio chamado tempo uma casa chamada terra, em que Mariano sai da Ilha, atravessa "a fronteira do mundo", vai para outra margem onde inicia a cidade, o mundo dos livros, que afasta as pessoas. "Você trazia consigo esses livros, esses cadernos, e ele olhava para eles como se fossem armas apontadas contra a nossa família." ${ }^{439}$. E acrescenta: "Não foi lá fora que o senhor estudou? Está bem mas não está certo. Os livros são um estrangeiro, para mim. Porque eu estudo na chuva. Ela é minha ensinadora." ${ }^{40}$. Ou então: "o senhor lê o livro, eu leio o chão."441. Fica evidente, nessas passagens, que a escrita separa o homem da natureza, enquanto a oralidade a ela o conjuga. O livro, como lugar privilegiado da escrita, é considerado elemento de cisão do homem com a natureza. Entretanto, como instrumento da modernidade, é utilizado por Mia Couto, como uma espécie de fio umbilical, para promover essa reconciliação do homem moçambicano com sua terra, com sua tradição e do homem universal com a natureza.

Ainda na esteira desse pensamento sobre o livro, apresenta-se a discussão sobre o valor da escola - lugar em que se institui a escrita, a qual, apesar de ser "barco", favorecendo contato com outros universos, distancia o homem da natureza e de suas raízes, transformando-o em um "quem não sei", alguém a quem foi destituída a infância, uma vez que lhe rouba o passado, como se verifica em 0 último voo do flamingo:

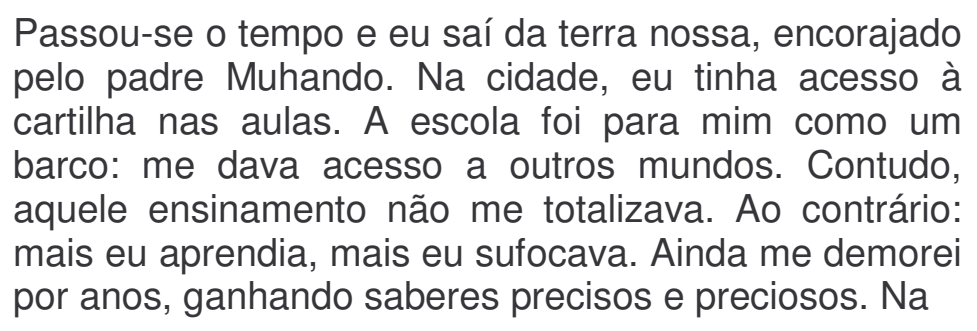

\footnotetext{
${ }^{438}$ COUTO, Mia. Um rio chamado tempo, uma casa chamada terra. São Paulo, Companhia das Letras, 2003. p.43.

${ }^{439}$ Idem, ibidem. p.66.

${ }^{440}$ Idem, ibidem. p. 149 .

${ }^{441}$ COUTO, Mia. O último voo do flamingo. São Paulo, Cia das Letras, 2005. p.155.
} 
viagem de regresso não seria eu que voltava. Seria um quem não sei, sem minha infância. Culpa de nada. Só isto; sou árvore nascida em margem. Mais lá, no adiante, sou canoa, a fugir pela corrente; mais próximo sou madeira incapaz de escapar do fogo. ${ }^{442}$

Em África, como país colonizado, a cultura escrita é imposta e se sobrepõe à cultura oral. Um ser que se submete à cultura do outro, esquecendo de suas raízes é sempre cindido, "árvore nascida em margem", isto é, homem marginal, porque está na margem entre duas culturas. Daí a reflexão da personagem: Na margem de lá, "sou canoa", posso deslizar conhecendo outros mundos; mas na margem de cá, "sou madeira", matéria de que se faz a canoa. Contudo, não é possível ser canoa, desconsiderando a matéria de que ela se faz. Sendo madeira, não se pode apartar de sua força vital: o fogo. Ser feito pelo fogo significa ser portador de paixões, de conhecimento intuitivo, de afetividade ardente, de desejo, de iluminação, de sabedoria divina, de sagrado. Dessa maneira, infere-se que, para se formar um ser inteiro, tendo assegurada sua identidade, é preciso, sobretudo nas culturas periféricas, colonizadas, considerar a "infância", o passado, a tradição e a forma de conhecimento de mundo que as mobiliza: o conhecimento mágico, intuitivo e grávido de sagrado.

Para isso, há de se valorizar a figura do velho, pois este compõe a escola do mais novo, sendo capaz de ensiná-lo a conservar as raízes. Por abrigar o passado, a sabedoria ancestral, o velho é autoridade autóctone e configura-se como símbolo de resistência, cabendo-Ihe a tarefa de conservar a unidade do grupo, os valores da comunidade, sustentados, primordialmente, pelo conhecimento mítico e sagrado, como se nota em: "Agora, sabe o que faço? Venho perto do rio e escuto as ondas: e, de novo, nascem os azuis. Como, agora, estou escutar o azul." ${ }^{443}$. Assim, portador de uma sabedoria aurática, capaz de auscultar a natureza, o velho apresenta-se como homem religioso - re-ligado com o Cosmos.

${ }^{442}$ COUTO, Mia. O último voo do flamingo. São Paulo, Cia das Letras, 2005. p.48.

${ }^{443}$ COUTO, Mia. Um rio chamado tempo, uma casa chamada terra. São Paulo, Companhia das Letras, 2003. p.20. 
Esse conhecimento sagrado é transmitido aos mais novos, como afirma o narrador-personagem de A chuva pasmada: "herdei de meu avô o sonho costumeiro de ir ter com o mar. Ser rio e fluir. Água em água, onda em onda, até escutar o grito agudo da gaivota" 444 .

Essa íntima e sacralizada relação do velho e do novo, do avô e do neto, é brilhantemente registrada em outra passagem de $A$ Chuva pasmada, em que o avô alia sabedoria a uma força onírica e as transmite ao neto:

[...] tinha visto um peixe subindo nos céus, imitando o vôo de um pássaro. Os da casa riram-se: o avô e seus delírios. Mas eu gostei de acreditar e, no meu pensamento, já cardumes atravessavam as nuvens, rebrilhando entre a sarapintada claridade. E cheguei mesmo a escutar 0 bater das barbatanas, 0 ar assobiando entre as coloridas escamas dos peixes. ${ }^{445}$

Pelo poder da palavra em fazer-crer, aliado a um conhecimento imaginante, o avô vai, progressivamente, aproximando-se do neto. Essa aproximação do velho e do novo não se dá apenas como contato físico e afetivo assegurador da transmissão da experiência, mas ela ocorre, também, como qualidade de conhecimento que ambos carregam e partilham, revelando um modo semelhante de estar no mundo. Em Estórias Abensonhadas, descreve: "O avô era um homem em flagrante infância, sempre arrebatado pela novidade de viver."446

Nas sociedades tradicionais, o velho tem lugar de honra porque é "guardião do tesouro espiritual da comunidade, a tradição" ${ }^{\text {"447 }}$; Ele é ponte entre o mundo dos que foram e o mundo dos que irão, como já mostramos. A criança, guardiã do porvir, também sabe do "mundo de lá", como se constata: "Nesta manhã tão recente, uma criança vem caminhando. Quem é este menino que faz do mundo outro menino? Deixemos seu nome, esqueçamos seu lugar. Dele se engrandece apenas a avó: que o miúdo tem intimidades com o mundo de lá [...]". ${ }^{448}$

Por isso, tanto o velho quanto a criança comungam com o sagrado. Ao alinhavar essas duas pontas da vida - o passado e o porvir, o velho e criança, Mia

\footnotetext{
${ }^{444}$ COUTO, Mia. A chuva pasmada. Lisboa, Editorial Caminho, 2004. p.56.

${ }^{445}$ Idem, ibidem. p. 24.

${ }^{446}$ COUTO, Mia. Estórias Abensonhadas. 2.ed., Lisboa, Editorial Caminho, 1998. p.9.

${ }^{447}$ BOSI, Ecléa. Memória e Sociedade. 3.ed., São Paulo, Companhia das Letras, 1994. p.82.

${ }^{448}$ COUTO, Mia. Estórias Abensonhadas. 2.ed., Lisboa, Editorial Caminho, 1998. p.57.
} 
Couto borda um presente que se faz pela costura do passado no futuro. Como afirma Laura Cavalcanti Padilha ${ }^{449}$ :

[...] o novo e o velho, juntos e interativamente articulados, eis uma vez mais reatualizada, no corpo do novo discurso, a imagem fundadora.[...] Com essa troca a interação velho/novo se torna, nas malhas do moderno tecido-texto, cada vez mais intensa e fecundante, com a tradição e a transformação recriando-se mutuamente.

Esse movimento dialético entre o velho e o novo traduz-se nos movimentos de criação e destruição, de vida e morte, de Caos e Cosmos entendidos como cosmogonia e escatologia, nas palavras de Mircea Eliade. Nesse caso, ao pensamento de Mircea Eliade, é preciso acrescentar que essas duas ordens se fecundam mútua e dialeticamente no processo de transformação e implicam luta, por se tratarem de forças antagônicas, portanto compõem uma iniciação. A síntese desalienadora advinda da interação dos elementos mais velhos e mais novos, fecundando velhice e infância, atestará um novo dinamismo na cultura africana nascido no útero do velho, como se lê no romance Varanda do Frangipani, em que o protagonista é uma criança-velho: "o menino que assim nascera certamente trazia novidades, presságios sobre o futuro da terra" ${ }^{450}$.

Em consonância com Ecléa Bosi ${ }^{451}$ :

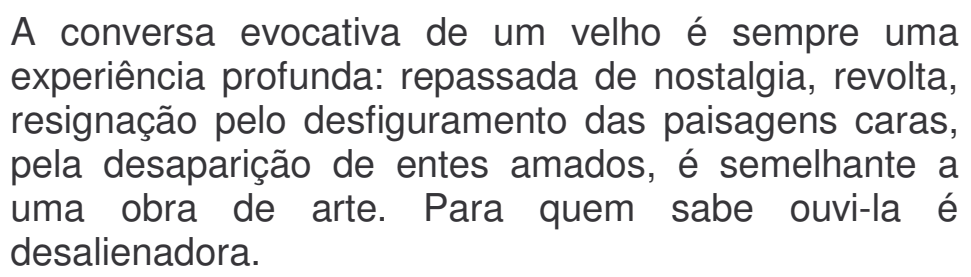

Assim, também, uma literatura que se faz de maneria iniciática, pela fecundação do velho e do novo, da voz e da letra, torna-se um entrelugar festivo e desalienador em que se anuncia a proposta humanizadora.

\footnotetext{
${ }^{449}$ PADILHA, Laura. Entre voz e letra: o lugar da ancestralidade na ficção angolana do século XX. Rio de Janeiro, EDUFF, 1995. p.44.

${ }^{450}$ COUTO, Mia. A varanda do frangipani. 7.ed., Lisboa, Editorial Caminho, 2003. p.33.

${ }^{451}$ BOSI, Ecléa. Memória e Sociedade: lembranças de velhos. 13. ed., São Paulo, Cia das Letras, 1994. p.83.
} 
Em texto de abertura de Vozes anoitecidas, confessa Mia Couto ${ }^{452}$ :

O que mais dói na miséria é a ignorância que ela tem de si mesma. Confrontados com a ausência de tudo, os homens abstêm-se do sonho, desarmando-se do desejo de serem outros. Existe no nada essa ilusão de plenitude que faz parar a vida e anoitecer as vozes. Estas estórias desadormeceram em mim sempre a partir de qualquer coisa acontecida de verdade mas que me foi contada como se tivesse ocorrido na outra margem do mundo. Na travessia dessa fronteira de sombra escutei as vozes que vazavam o sol. Outras foram as asas no meu vôo de escrever. A umas e outras dedico este desejo de contar e de inventar.

Entre velho-contador e menino-inventor, no seu fingir estético, Mia Couto imita o avô de A Chuva Pasmada, que se encarrega de contar uma lenda da fundação do lugar em que vivem as personagens desesperadas com a secura em suas vidas, proveniente da falta de chuva. Aliás, o avô é o que sempre finge: "fingia pescar, fingia até viver", mas nunca mentia, como ensina: “- inventei mas não menti. Você vai aprender, meu neto: toda a viagem é um faz de conta"453.

Em seu fazer-crer, declara, em entrevista à Revista Via Atlântica, não ser "tanto um construtor de narrativas", mas um "construtor de personagens": "depois eu vou inventando histórias para que essa personagem tenha sentido" [...] ० que se acende, aquilo que se ilumina, são personagens, são pessoas.[...] Acho que o prazer da escrita está aí, é tu saberes que estás a inventar histórias para pessoas que não têm história" ${ }^{454}$.

Suas personagens são símbolos de diversas formas de existência e de lutas humanas. De acordo com o prefácio de José Craveirinha ${ }^{455}$, em Vozes Anoitecidas:

Ou equívoco nosso ou este Vozes Anoitecidas imbui-se de um referencial algo importante para nós, moçambicanos, literariamente: indo afoitamente remexer as tradicionais raízes do Mito, o narrador concebe uma tecitura humano-social adequada a determinados lugares e respectivos quotidianos. Mia

\footnotetext{
${ }^{452}$ COUTO, Mia. Vozes Anoitecidas. 8.ed., Lisboa, Editorial Caminho, 1987. p.19.

${ }^{453}$ COUTO, Mia. A chuva pasmada. Lisboa, Editorial Caminho, 2004. p.50.

${ }^{454}$ COUTO, Mia. In: Revista Via Atlântica. n 8. São Paulo, Departamento de Letras Clássicas e Vernáculas, Faculdade de Filosofia, Letras e Ciências Humanas, Universidade de São Paulo, 2005. p.216.

${ }^{455}$ CRAVEIRINHA, José apud COUTO, Mia. Vozes Anoitecidas. 8.ed., Lisboa, Editorial Caminho, 1987. p.10.
} 
Couto faz-se (transfigura-se) vários seus personagens pela atenta escuta de pessoas e incidentes próximos de si, porque o homem-escritor quer-se testemunha activa e consciente, sujeito também do que acontece e como acontece, já que desde a infância pôde saber-se objeto.

Habitando regiões diversas e carregando suas rezas e segredos, as personagens de Mia Couto colocam em evidência a própria história de Moçambique, sua formação, as várias identidades que a compõem: "Já não vejo brancos nem pretos, tudo para mim são mulatos" ${ }^{456}$.

Em geral, são nomes motivados por uma estória: em Um rio chamado tempo, uma casa chamada terra, apresenta-se tio Abstinêncio, que passara anos exilado dentro de casa, com medo da vida ou do viver. Isolado, ocupava-se em trançar lembranças até do que nunca tivera; Mariavilhosa, mãe do protagonista teve um destino maravilhoso, morrendo extraordinariamente, como se conta:

\begin{abstract}
Afogada era o modo de dizer. Ela suicidara-se, então, Avó? [...] O que ela fez, uma certa tarde, foi desatar a entrar pelo rio até desaparecer engolida pela corrente. Morrera? Duvidava-se. Talvez se tivesse transformado nesses espíritos da água, que, anos depois, reaparecem com poderes sobre os viventes. Até porque houve quem testemunhasse que, naquela derradeira tarde, à medida que ia submergindo, Mariavilhosa se ia convertendo em água. Quando entrou no rio, seu corpo já era água. $\mathrm{E}$ nada mais senão água. ${ }^{457}$
\end{abstract}

Agualberto salvo-erro é outra personagem, pai do protagonista de Mar me quer, e, após salvar uma mulher ilegítima com quem estava, volta com olhos de tubarão, depois de muito tempo na água; Temporina, de O último vôo do flamingo, é uma mulher de corpo exuberante com feições de anciã. Junhito, de Terra Sonâmbula, tem esse nome porque nascera no dia da Independência, 25 de junho. O pai pressente que ele morrerá. Para salvar o filho, ele é transferido para a capoeira que ficava no quintal onde aprenderia a comportar-se como as galinhas, sem brilho. Assim acontece de modo que ele até sonha ter sido um homem um dia.

\footnotetext{
${ }^{456}$ COUTO, Mia. Um rio chamado tempo, uma casa chamada terra. São Paulo, Companhia das Letras, 2003. p.20.

${ }^{457}$ Idem, ibidem. p. 105.
} 
Isso metaforiza a domesticação do espírito de ousadia, a perda da soberania de um povo recém-independente. Era preciso se comportar bem. Com isso, Mia Couto 458 tece uma crítica ao processo de dependência que impossibilitou fazer de seus participantes verdadeiros sujeitos da história:

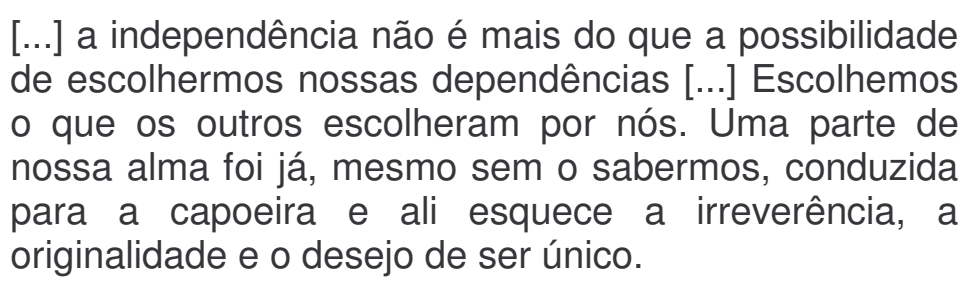

A personagem Tchuvisco, do romance Vinte e Zinco, possui lágrimas que trazem água da terra, alegoria da necessidade de renascimento em Moçambique. Epifane é a sagrada esposa em Vozes Anoitecidas. Alguns revelam um tom lúdico e de humor, como Júlio Novesfora (do conto "Os infelizes cáculos da felicidade") ou Jorge Pontivírgula (de "Jorojão vai embalando lembranças"), ambos de Estórias Abensonhadas, entre vários outros, cegos, loucos, personagens à deriva, em trânsito e transgressão de ordens e fronteiras, capazes de compor a heroicidade silenciada da cultura africana. Animais, ndladis (pássaros míticos), seres animados e inanimados, que povoam o imaginário africano de que as narrativas de Mia Couto são porta-vozes. Brancos, negros, crianças, velhos, homens, mulheres, pescadores, muitos que foram abandonados na sombra do esquecimento pela luz hierárquica das posses.

Contracenam, no palco narrativo, também, feiticeiros, adivinhos, xipocos (fantasmas, em uma das línguas locais), xicuembos (espíritos dos antepassados), como vozes representantes da ancestralidade africana e, ao mesmo tempo, sua resistência.

Em muitas obras, há capítulos introduzidos por epígrafes, em que se ouvem essas múltiplas vozes da comunidade, sobretudo a dos mais velhos. Dessa maneira, o caráter hegemônico da voz do narrador é relativizado, pela opção de inserir, no texto, a polifonia, ou seja, as várias vozes, diversos pontos de vista, valorizados como formas distintas de apreensão de uma realidade.

${ }^{458}$ COUTO, Mia. In: Revista Via Atlântica. n 8. São Paulo, Departamento de Letras Clássicas e Vernáculas, Faculdade de Filosofia, Letras e Ciências Humanas, Universidade de São Paulo, 2005. p.194. 
Também com a escolha dos nomes, Mia Couto assume sua vocação de fazer da escrita um lugar possível da reinvenção da condição humana. Essa vocação para a escritura é bem revelada no depoimento assinado pelo tradutor de Tizangara em $O$ último voo do flamingo, em que se lê:

\begin{abstract}
Hoje são vozes que não escuto senão no sangue como se a sua lembrança me surgisse não da memória, mas do fundo do corpo.[...] Coloquei tudo no papel por mando de minha consciência. [...] Agora, vos conto tudo por ordem de minha única vontade. E que preciso livrar-me dessas lembranças como o assassino que se livra do corpo da vítima. ${ }^{459}$
\end{abstract}

É especialmente na língua portuguesa que Mia Couto faz ressoar as vozes, povoando de tradição a modernidade. O português é a língua oficial em Moçambique, é a norma estabelecida nas escolas, nos textos oficiais, nos meios de comunicação, entretanto as línguas nativas são da comunicação diária, especialmente fora das regiões urbanas. Como o português é a segunda língua, ela sofre alterações, modificando-se tanto em sua forma oral quanto em sua forma escrita, ou seja, moçambicanizando-se.

Em 1979, Luís Bernardino Honwana, também célebre escritor moçambicano, após proferir palestra nos Estados Unidos, no momento das perguntas, ouve: "Agora que Moçambique é um país independente, por que vocês não abandonam o idioma do colonizador para falar e escrever sua própria língua?", à qual responde convictamente: "A língua portuguesa é nossa também". 460

Ficcionalmente, Mia Couto ${ }^{461}$ confirma isso em Terra Sonâmbula:

Pensava sobre a semelhança entre mim e Farida. Entendia o que me unia àquela mulher: nós dois estávamos divididos entre dois mundos. A nossa memória se povoava de fantasmas da nossa aldeia. Esses fantasmas nos falavam em nossas línguas indígenas. Mas nós já só sabíamos sonhar em português.[...] Farida queria sair de África, eu queria encontrar um outro continente dentro de África.

\footnotetext{
${ }^{459}$ COUTO, Mia. O último voo do flamingo. São Paulo, Cia das Letras, 2005. p.9.

${ }^{460}$ Conforme artigo publicado na revista Via Atlântica, n. 3, dez.1999.

${ }^{461}$ COUTO, Mia. Terra Sonâmbula. 8.ed., Lisboa, Editorial Caminho, 2004. p.103.
} 


\section{Ou em Varanda do Frangipani:}

Desculpe-me este meu português, já nem sei que língua falo, tenho a gramática toda suja, da cor desta terra. Não é só o falar que é já outro. É o pensar, inspetor. Até o velho Nhonhoso se entristece do modo como eu me desaportuguesei. ${ }^{462}$

Nessa perspectiva, Mia Couto amolda a língua portuguesa, transformando-a de código lingüístico da colonização em código lingüístico da moçambicanidade instrumento legítimo capaz de veicular a literatura de uma nova nação. Na contramão do que foi imposto, o autor transgride a norma, fundando outras relações com a lógica do discurso comum, buscando, na expressão livre e espontânea dos atores anônimos das camadas populares, urbanas e rurais, a matéria-prima de sua linguagem. Nesse projeto, são incorporados vocábulos das línguas locais, como se observa em: "Isso garça não é. É um 'mangondzwane'. É um pássaro-martelo, bicho coberto de lendas e maldições. Miserinha reconhecia-o sem deixar de olhar para o chão." ${ }^{463}$; "O Avô era o 'munumuzana', o mais-velho da família" ${ }^{464}$, apenas para ilustrar algumas das inúmeras ocorrências.

Dessa maneira, testemunham-se as trocas lingüísticas, "os encontros e desencontros entre valores culturais que, para se expressarem, têm que pedir licença a uma outra língua. [...]", como afirma Mia Couto ${ }^{465}$, em entrevista à Revista Via Atlântica. E acrescenta: "O que me fascina são as margens onde essas coisas se convertem em uma só coisa, onde essas identidades se misturam, convergem".

No limiar entre as coisas, entre "o normativo e o criativo", no dizer de Ana Mafalda Leite ${ }^{466}$, em Prefácio ao livro de Fernanda Cavacas, Mia Couto constrói sua ponte, um entrelugar de reflexão trans(lingüístico), traduzindo este desvairamento "brincriativo" existente há muito no falar cotidiano da língua. Essa é a maneira de o escritor nos apresentar um discurso novo.

\footnotetext{
${ }^{462}$ COUTO, Mia. A varanda do frangipani. 7.ed., Lisboa, Editorial Caminho, 2003. p.48.

${ }^{463}$ COUTO, Mia. Um rio chamado tempo, uma casa chamada terra. São Paulo, Companhia das Letras, 2003. p.27.

${ }^{464}$ Idem, ibidem. p.58.

${ }^{465}$ COUTO, Mia. In: Revista Via Atlântica. n 8. São Paulo, Departamento de Letras Clássicas e Vernáculas, Faculdade de Filosofia, Letras e Ciências Humanas, Universidade de São Paulo, 2005. p.208-209.

${ }^{466}$ LEITE, Ana Mafalda apud CAVACAS, Fernanda. Mia Couto: brincriação vocabular. Lisboa, Mar Além Edição de Publicações e Instituto Camões, 1999. p.7.
} 
O papel em que se inscreve a palavra de Mia Couto nomeia o chão de sua terra, como nos revela em $O$ último vôo do flamingo: "o chão é um papel, tudo se escreve nele" 467 . Nas páginas do chão moçambicano, desenham-se as iniciais de suas identidades e Mia Couto faz questão de sublinhar o que as culturas legitimadas como hegemônicas insistiram em rasurar. Esse gesto nomeador, que poderia se confundir com um valor ideológico e utilitário do verbo, de maneira alguma, não compromete o estético; ao contrário, engaja o leitor na missão transformadora da escrita, de forma a abrir a visão para tudo quanto o arquivo do Ocidente cegou. Ao nomear, Mia Couto confere existência e inscreve as identidades de seu país. Estabelece, de fato, o espaço literário como um entrelugar, um território de partilha e de fronteira, no qual confluem o rural e o urbano, o sobrenatural e o natural, a vida e a morte, o interdito e o permitido, a oralidade e a escrita, o sagrado e o profano, o tradicional e o moderno.

Como ele mesmo canta, em Raiz de orvalho e outros poemas:

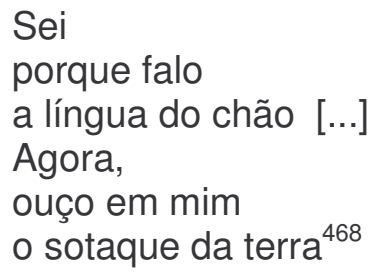

É com esse intuito que, no chão do livro, enraíza as múltiplas vozes de sua terra, tentando cultivá-las em letra. Fertilizando a escritura com as substâncias da oralidade, ele traduz o pensar, o sentir e o querer dos moçambicanos. Como ele mesmo afirma: no país, "noventa por cento existem na oralidade, moram na oralidade, pensam e amam nesse universo. Aí eu funciono muito como tradutor. Tradutor não de línguas mas desses universos."

Ao traduzir esses universos, o autor inaugura uma realidade outra. Isso é possível porque sua escrita abre fendas na língua do colonizador, como forma de subverter a ordem colonial e consagrar um espaço em que os moçambicanos possam expressar suas raízes e sua maneira de estar no mundo. A qualidade da escrita ficcional de Mia Couto revela forte consciência das tensões entre palavra e

\footnotetext{
${ }^{467}$ COUTO, Mia. O último voo do flamingo. São Paulo, Cia das Letras, 2005. p.186.

${ }^{468}$ COUTO, Mia. Raiz de orvalho e outros poemas. 3.ed., Lisboa, Editorial Caminho, 1999. p.63.

${ }^{469}$ REVISTA VIA ATLÂNTICA. n 8. São Paulo, Departamento de Letras Clássicas e Vernáculas, Faculdade de Filosofia, Letras e Ciências Humanas, Universidade de São Paulo, 2005. p.208.
} 
realidade, apresentando aquela como um signo grávido de potencialidades motivadoras de transformação. O dizer que inicia, metalingüisticamente, a narrativa de Estórias Abensonhadas é:

Toda estória se quer fingir verdade. Mas a palavra é um fumo, leve de mais para se prender na vigente realidade. Toda verdade aspira ser estória. Os factos sonham ser palavra, perfumes fugindo do mundo. Se verá neste caso que só na mentira do encantamento a verdade se casa à estória. ${ }^{470}$

O que se desenha no fingir estético de Mia Couto é uma forma de verter a realidade moçambicana em letra. Pela artesania do verbo, o autor compromete-se com as possibilidades inventivas de transformação da vida domesticada pelo autoritarismo, revelando sua missão de sublinhar verdades humanas profundas.

Seus escritos literários construídos em páginas da terra engravidam o leitor de encantamento e de sonho. E este é seu projeto estético e seu projeto político, como ele mesmo assume:

[...] o escritor não é apenas aquele que escreve. É aquele que produz pensamento, aquele que é capaz de engravidar os outros de sentimento e de encantamento. Mais do que isso, o escritor desafia os fundamentos do próprio pensamento. Ele vai mais longe do que desafiar os limites do politicamente correcto. Ele subverte os próprios critérios que definem o que é correcto, ele questiona os limites da razão. Os escritores moçambicanos cumprem hoje um compromisso de ordem ética: pensar este Moçambique e sonhar outro Moçambique.[...] esperamos pelo reacender do amor entre a escrita e a nação enquanto casa feita para sonhar. ${ }^{471}$

Para ele, o escritor tem compromisso com a liberdade. Por isso, sua literatura posiciona o leitor nesse entrelugar, entre a tradição e a modernidade, entre a memória e as possibilidades do vir-a-ser. Isso se resume na imagem da varanda de O último voo do flamingo. Ao emprestar sua voz à da mãe do narrador-personagem, Mia Couto ${ }^{472}$ afirma que "o melhor lugar para se chorar era a varanda", porque "à frente estava o mundo e seus infinitos; atrás estava a casa, o primeiro abrigo".

\footnotetext{
${ }^{470}$ COUTO, Mia. Estórias Abensonhadas. 2.ed., Lisboa, Editorial Caminho, 1998. p.51.

${ }^{471}$ COUTO, Mia. Pensatempos: textos de opinião. 2.ed., Lisboa, Editorial Caminho, 2005. p.63.

${ }^{472}$ COUTO, Mia. O último voo do flamingo. São Paulo, Cia das Letras, 2005. p.206.
} 
Conforme Ernst Fischer ${ }^{473}$ :

[...] toda arte é condicionada pelo seu tempo e representa a humanidade em consonância com as idéias e aspirações, as necessidades e esperanças de uma situação histórica particular. Mas, ao mesmo tempo, a arte supera essa limitação e, de dentro do momento histórico, cria também um momento de humanidade que promete constância no desenvolvimento.

Mia Couto, consciente de seu fazer criativo, a este confere uma função social, refletindo o real e sobre o real, apontando possibilidades-sonhos de mudança e ajudando a mudar. A verdadeira mudança para Moçambique consiste em costurar os fios da modernidade no tecido da tradição. Por isso, Mia Couto faz questão de registrar cenas em que comparece a mundivisão tradicional da cultura africana.

Em O último voo do flamingo, o filho era especial, os deuses falavam pela sua boca, por ele ter sofrido de doenças graves, quando menino. "A morte ocupara, essas vezes, meu corpo, mas nunca me chegara a levar. Nos saberes locais, aquela resistência era um sinal: eu traduzia palavras dos falecidos" ${ }^{\prime 474}$.

Crendices, superstições acompanham, naturalmente, a vida tradicional, como se reitera em Um rio chamado tempo, uma casa chamada terra: "passa sem cantar. Um frio me golpeia. Ainda me lembro do mau presságio que é o silêncio do 'mangondzwane'. Algo grave estaria para ocorrer na vila" ${ }^{\text {"475; }}$ ou "toda a roupa recebe

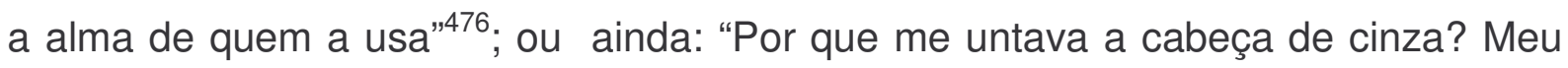
pai diz que é para meu bem, para afastar maus espíritos"477;

Em Estórias Abensonhadas, narram-se superstições: "Era sua advertência. Tirar água no sentido contrário ao da corrente pode trazer desgraça. Não se pode contrariar os espíritos que fluem." ${ }^{478}$, ou "Para Tia Tristereza a chuva não é assunto de clima mas recado dos espíritos."

\footnotetext{
${ }^{473}$ FISCHER, Ernst. A necessidade da arte. Trad. Leandro Konder. 9.ed., Rio de Janeiro, Guanabara Koogan, 2002. p.17.

${ }^{474}$ COUTO, Mia. O último voo do flamingo. São Paulo, Cia das Letras, 2005. p. 139.

${ }^{475}$ COUTO, Mia. Um rio chamado tempo, uma casa chamada terra. São Paulo, Companhia das Letras, 2003. p.27.

${ }^{476}$ Idem, ibidem. p. 163.

${ }^{477}$ Idem, ibidem. p. 214.

${ }^{478}$ COUTO, Mia. Estórias Abensonhadas. 2.ed., Lisboa, Editorial Caminho, 1998. p.10.

${ }^{479}$ Idem, ibidem. p.45.
} 
Em A chuva pasmada, desnuda-se a presença dos elementos sagrados como inseparáveis da vida profana:

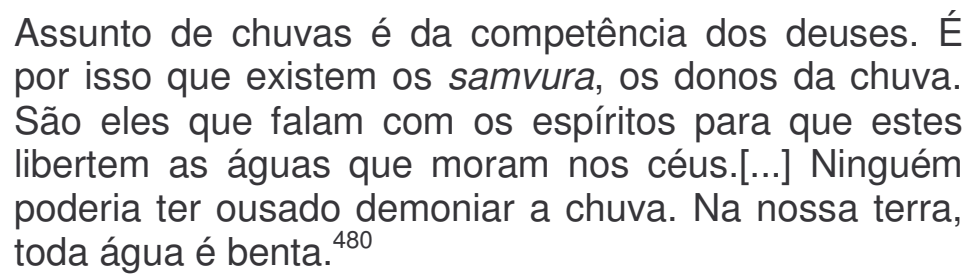

Em Mar me quer, observa-se a coexistência de tempos: dos vivos e dos mortos:

\begin{abstract}
[...] um arrepio me atravessou. Aquilo era um sinal. Alguém, da outra margem do mundo, me estava vigiando. Mania dos mortos é teimarem em ser humanos. E ali, entre mim e Luarmina, se vertia a mensagem dos divinos. ${ }^{481}$
\end{abstract}

A idéia do rito, do eterno retorno do tempo, da repetição está presente em $A$ Chuva Pasmada: "Ntweni sacrificara a sua vida para libertar a água e salvar os seus. Esse destino revivia agora em minha mãe. Nada sucede de primeira vez, tudo é reedição de algo sucedido."482

Mito e rito entrelaçam-se na voz do protagonista de Um rio chamado tempo, uma casa chamada terra: "Foi um caniço que fez nascer o Homem. Estamos repetindo a origem do mundo. Afundo a cana bravia na areia. Como uma bandeira, o caniço parece envaidecido, apontando o poente" ${ }^{483}$.

A relação comparativa do caniço com a bandeira mostra o diálogo do passado com o futuro, do mito com a história, do tradicional com o moderno. O fato de 0 caniço, assemelhado à bandeira, apontar para o poente pressupõe o fim de uma era e o suposto renascer de outra. Tanto que essa fala de Marianito com Curozero termina da seguinte forma: “- Seu Avô está abrindo os ventos. A chuva está solta, a terra vai conceber." ${ }^{484}$

\footnotetext{
${ }^{480}$ COUTO, Mia. A chuva pasmada. Lisboa, Editorial Caminho, 2004. p.9.

${ }^{481}$ COUTO, Mia. Il. João Nasi Pereira. Mar me quer. 5.ed., Lisboa, Editorial Caminho, 2000. p.36.

${ }^{482}$ COUTO, Mia. A chuva pasmada. Lisboa, Editorial Caminho, 2004. p.60.

${ }^{483}$ COUTO, Mia. Um rio chamado tempo, uma casa chamada terra. São Paulo, Companhia das Letras, 2003. p.240.

${ }^{484}$ Idem, ibidem. p. 240
} 
A tradição oral, como já afirmamos, é permanentemente resgatada nas suas formas simples, em mitos, lendas, adivinhas, ditados, valorizando a consciência mítica e um conhecimento de mundo permeado pelo sagrado. A relação do homem com os deuses é, a todo tempo, retomada nas obras de Mia Couto: "Estão cumprindo a cerimônia que o 'nganga' ordenou para que a terra voltasse a abrir. A maldição que tombara sobre nossa Ilha só podia ser vencida por esforço de todos. Em todo lado, os ilhéus enviavam sinais de entendimento com os deuses."

A natureza é respeitada e valorizada, como uma deusa a quem se deve pedir permissão: "Respeitam a tradição: antes de entrar na água, cada uma delas pede permissão ao rio" ${ }^{\prime 486}$.

Essa forma antiga de tratar os elementos que nos rodeiam, de fato, como seres, estabelece um tipo de relação com o mundo infinitamente diferente da forma moderna em que tudo se converte em objeto, em coisa, inclusive o próprio homem. Para Joseph Campbell ${ }^{487}$, o ego que vê nos animais, nas pedras, nas árvores um "vós" não é o mesmo que vê uma coisa.

Ao pedir permissão ao rio e reconhecê-lo como um ser merecedor de respeito, pode-se constatar o animismo ${ }^{488}$, tão presente nas sociedades primitivas, registrado na construção estética de Mia Couto.

Assim, ele vai alinhavando, na artesania da letra, os fios de uma voz antiga, que se manifesta como livre expressão de um pensamento imaginante e de uma forma de estar no mundo animada pela afetividade e pela intuição mágica. Vai costurando uma nova forma de viver, que conjuga o velho e o novo.

Esse duplo movimento pontilhado pelo entrecruzar das tramas da tradição com as urdiduras da modernidade torna-se visível, simbolicamente, pela reiterada

${ }^{485}$ COUTO, Mia. Um rio chamado tempo, uma casa chamada terra. São Paulo, Companhia das Letras, 2003. p.211.

${ }^{486}$ Idem, ibidem. p. 211.

${ }^{487}$ CAMPBELL, Joseph. O poder do mito. Trad. Carlos Felipe Moisés. São Paulo, Associação Palas Athena, 1990. p.82.

${ }^{488}$ Segundo o antropólogo inglês Sir Edward B. Taylor (Primitive Culture,1871), que cunhou o termo, o animismo designa manifestação religiosa na qual se atribui a todos os elementos do cosmos, da natureza, os seres vivos e a todos os fenômenos naturais um princípio vital e pessoal, chamado de "ânima" ou alma. Assim, todos esses elementos são passíveis de possuir sentimentos, emoções, vontades ou desejos, e até mesmo inteligência. Seu princípio é de que tudo no Cosmos tem alma; a alma é transferível. Aquele que transfere alma não perde a totalidade dela, mas quem recebe perde parte ou a totalidade de sua alma, sendo tomado pela alma do doador. Incluindo a crença, também, que atribui vida aos mortos, ou seja, a alma humana continua a viver em um estado espiritual depois da morte, permanecendo nas redondezas por onde a pessoa viveu. 
utilização de dois elementos que compõem o imaginário moçambicano - a terra e a água - sintetizados em um terceiro: a ilha-Moçambique.

Para elucidar nosso pensamento, abordaremos, com mais detalhes, no curso das próximas páginas, essas três simbologias.

\subsubsection{A simbologia da terra}

A terra é substância universal, considerada a prima matéria, separada das águas, matriz de todas as formas. Antes de ser considerada Deusa-Mãe, divindade da fertilidade, a Terra impôs-se, diretamente, como Mãe, 'Telllus Mater'.

Simbolizando a função maternal, a Grande Mãe é aquela que deu origem aos seres, e se identifica, por isso, com a fecundidade, possuindo infinita capacidade de dar frutos. Fonte do ser e protetora, ela é mãe nas primeiras experiências religiosas ou intuições míticas, lugar por onde circunda o homem.

Para a consciência religiosa primitiva, segundo Mircea Eliade ${ }^{489}$, a terra "é o fundamento de todas as manifestações". Os homens são ligados a ela, são "gente da terra". Por isso, a expropriação do chão africano pelos estrangeiros é uma violação à própria cultura, conforme se percebe no trecho: "nem a terra, que é propriedade exclusiva dos deuses, nem a terra é poupada das ganâncias. Nada é nosso nos dias de agora. Chega um desses estrangeiros, nacional ou de fora, e nos arranca tudo de vez. Até o chão nos arrancam"490. Arrancar o chão significa destituir o ser de seu próprio fundamento, de sua própria cultura, pois é na terra, útero da vida, que ela se gesta, como se percebe no fragmento: "a terra guarda a raiz da gente" ${ }^{\prime 41}$. Existe uma solidariedade mística com a terra natal, "é a experiência religiosa da autoctonia: as pessoas sentem-se gente do lugar" ${ }^{\prime \prime 92}$.

O final do livro O último voo do flamingo traz a cena em que, insatisfeitos com os andamentos do país, os antepassados e deuses, decidem transportá-lo para "esses céus que ficam no fundo da terra", "à espera de um tempo favorável para

\footnotetext{
${ }^{489}$ ELIADE, Mircea. Tratado de história das religiões. São Paulo, Martins Fontes, 1993. p.197.

${ }^{490}$ COUTO, Mia. O último voo do flamingo. São Paulo, Cia das Letras, 2005. p.152.

${ }^{491}$ Idem, ibidem. p. 200.

${ }^{492}$ ELIADE, Mircea. O sagrado e o profano: a essência das religiões. Trad. Rogério Fernandes. Lisboa, Edição Livros do Brasil.s.d. p. 150.
} 
regressar ao seu próprio chão", até que se construa uma nova maneira de estar no mundo, amparada na liberdade.

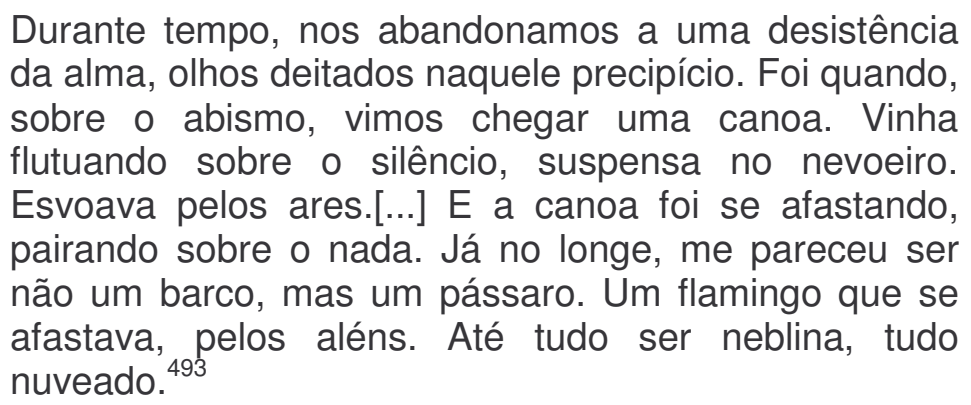

A situação de crise da comunidade faz com que tudo pareça "nuveado", mas, pelo imaginário, vê-se possível transformar a vida. Com auxílio de uma canoa, ou de um pássaro, sempre há possibilidade de metamorfosear a vida e encaminhar-se para outra condição existencial. O importante é que tudo isso ocorreu no "fundo da terra", por ser esta o útero da vida, por ser "mãe universal de sólidas bases, avó venerável que nutre no seu solo tudo que existe" no entender de Mircea Eliade ${ }^{494}$. E acrescenta: "tudo que sai da terra é dotado de vida e tudo que volta para a terra é de novo provido de vida". Isso explica a concepção da morte apresentada por Mia Couto em várias obras.

Em Vozes Anoitecidas, conta-se: "Minha vida não é um caminho. É uma pedra fechada à espera de ser areia. Vou entrando nos grãos do chão, devagarinho. Quando me quiserem enterrar já eu serei terra. Já que não tive vantagem na vida, esse será o privilégio da minha morte."

A terra é o espaço sagrado de transformação, revelando-se como um território-limiar que abriga morte e vida.

Em A chuva pasmada, o título do capítulo "Um homem à espera de ser terra" revela a importância do chão. Lê-se: "nascemos água e morremos terra" ${ }^{496}$

\footnotetext{
${ }^{493}$ COUTO, Mia. O último voo do flamingo. São Paulo, Cia das Letras, 2005. p.218.

${ }^{494}$ ELIADE, Mircea. O sagrado e o profano: a essência das religiões. Trad. Rogério Fernandes. Lisboa, Edição Livros do Brasil.s.d. p.148.

${ }^{495}$ COUTO, Mia. Vozes Anoitecidas. 8.ed., Lisboa, Editorial Caminho, 1987. p.84.

${ }^{496}$ COUTO, Mia. A chuva pasmada. Lisboa, Editorial Caminho, 2004. p.50.
} 
Esse binômio 'homo-humus' não deve ser compreendido no sentido de que o homem seria terra porque é mortal, mas no sentido de que é vivo porque vem da Terra-Mãe e volta para ela. ${ }^{497}$

Em Raiz de Orvalho e outros poemas, nota-se, igualmente, a Terra como o ventre do qual participam caos e cosmos, morte e vida - lugar sagrado de transformação.

\author{
Pequeninura do morto e do vivo \\ O morto \\ abre a terra: encontra um ventre \\ o vivo \\ abre a terra: descobre um seio.(1986) ${ }^{498}$
}

Assim também se espera que o futuro de Moçambique seja gestado dentro da própria terra, sem perder a substância da memória. E a literatura tem esse papel de convite a revisitar o tempo, a ter acesso às lembranças. Conforme entrevista dada por Mia Couto ${ }^{499}$ a $O$ Estado de São Paulo, "a escrita literária pode ser uma forma sem ressentimento nem dedos acusatórios para reconquistarmos e nos reconciliarmos com nossa própria memória".

Para tanto, é preciso cultivar o registro da terra e do que ela traz acerca da tradição, evidentemente não no seu aspecto estereotipado e exótico, mas no que ela pode significar, realmente, no plano da construção das várias identidades africanas.

Em Estórias Abensonhadas, registra-se um curioso fato cultural da tradição africana: "Dar parto devia ser sobre a terra, a mãe das mães. Assim é o mandamento das tradições"500. No conto "O último voo do tucano", de Contos do nascer da terra, a personagem grávida deitava-se de ventre para baixo na terra e ficava imóvel. Note-se o diálogo: “- que fazia ela assim, barriga na barriga do mundo?/- Ensino o futuro menino a ser terra." ${ }^{501}$ Nessa passagem, observa-se a preocupação em se ensinar, pela experiência, a cultivar a tradição, assim, pode-se construir o novo sem descartar o velho.

\footnotetext{
${ }^{497}$ ELIADE, Mircea. Tratado de história das religiões. São Paulo, Martins Fontes, 1993. p.205.

${ }^{498}$ COUTO, Mia. Raiz de orvalho e outros poemas. 3.ed., Lisboa, Editorial Caminho, 1999. p.89.

${ }^{499}$ COUTO, Mia. "Vivemos a vertigem do caos". O Estado de São Paulo, 16 de junho de 2007.

${ }^{500}$ COUTO, Mia. O último voo do flamingo. São Paulo, Cia das Letras, 2005. p.27-28.

${ }^{501}$ COUTO, Mia. Contos do nascer da terra. 6.ed., Lisboa, Editorial Caminho, 2006. p.61.
} 
Em entrevista a O Estado de São Paulo, Mia Couto ${ }^{502}$ afirma que "aqueles que se sentem excluídos num certo modelo de sociedade são tentados a aderir a um discurso manipulador e a tentação é esta: já que não tenho lugar no futuro e destruo o próprio Tempo, já que a minha pátria não é minha, eu a converterei num nãolugar". Em resistência a isso, Mia Couto lança sua voz, acreditando na possibilidade inerente à literatura de se configurar como um entrelugar no qual seja possível ler, nas páginas da escrita, as páginas da vida, ou seja, ao fazer-crer, torna possível viver, rever e transformar a realidade. Portanto, a arte da palavra cumpre seu papel iniciático.

No relatório do italiano, de O ultimo voo do flamingo, lê-se: "todo este imenso país se eclipsou, como que por golpe de magia. Não há território, nem gente, o próprio chão se evaporou num imenso abismo." ${ }^{503}$. Enquanto esperavam por outro barco ou por outro vôo do flamingo, as duas personagens fizeram da folha em que escreviam um pássaro de papel e lançaram-no sobre o abismo, "reinvestindo na palavra o mágico reinício de tudo", recuperando os dizeres de Mia Couto ${ }^{504}$ em discurso proferido na entrega do Prêmio Mário António, da Fundação Calouste Gulbenkian, em 12 de junho de 2001. Na voz do narrador, a estória termina: "Ainda assim me deixei quieto, sentado. Na espera de um outro tempo. Até que escutei a canção de minha mãe, essa que ela entoava para que os flamingos empurrassem o sol do outro lado do mundo" ${ }^{505}$.

Mia Couto ${ }^{506}$ assume seu papel de escritor comprometido com sua terra. No mesmo discurso proferido em 12 de junho de 2001, afirma:

Contra a indecência dos que enriquecem à custa de tudo e de todos, contra os que têm as mãos manchadas de sangue, contra a mentira, o crime e o medo, contra tudo isso se deve erguer a palavra dos escritores. Esse compromisso com a minha terra e o meu tempo guiou não apenas este livro como os romances anteriores. Em todos eles me confrontei com os mesmos demônios e entendi inventar o mesmo território de afecto, onde seja possível refazer crenças e reparar o rasgão do luto em nossas vidas.

\footnotetext{
${ }^{502}$ COUTO, Mia. In: "Vivemos a vertigem do caos". O Estado de São Paulo, 16 de junho de 2007.

${ }^{503}$ COUTO, Mia. O último voo do flamingo. São Paulo, Cia das Letras, 2005. p.224.

${ }^{504}$ Idem, ibidem. p.224.

${ }^{505}$ Idem, ibidem. p.220.

${ }^{506}$ Idem, ibidem.p. 224.
} 
Em Terra Sonâmbula, as letras se convertem em páginas da terra reafirmando a missão iniciática do escritor em transformar experiências vividas em experiências sonhadas, capazes de modificar seres e gerar possibilidades outras de vida. Assim, com páginas da terra, Mia Couto vai construindo suas obras, útero de vozes e letras sensivelmente moldadas, esculpidas com a forma de um entrelugar, um território iniciático capaz de fazer nascer, no novo leitor, um novo modo de olhar o mundo. Esse novo modo de nascer no mundo advém não apenas da travessia simbólica pela terra, mas também pela experiência fecundante e regeneradora da água - simbologia de que trataremos a seguir.

\subsubsection{A simbologia da água}

A água é substância líquida que flui, fonte de vida, signo das virtualidades, elemento regenerador, de pureza e de fertilidade. Para Mircea Eliade ${ }^{507}$, as águas possuem um valor sagrado, são 'fonte et origo', "elemento cosmogônico", "matriz de todas as possibilidades de existência", "totalidade das virtualidades". Sempre germinativas, elas "precedem as formas e suportam qualquer criação".

A água abriga significado importante na obra de Mia Couto. Em decorrência do momento histórico - pós-colonial - por que passa a cultura moçambicana, na travessia entre a tradição e a modernidade, a simbologia da água catalisa o desejo de projetar esse novo nascimento do país após seus rituais iniciáticos, como podem ser consideradas as guerras: de libertação e civil, ocorridas e denunciadas pelo escritor em suas obras.

Em A chuva pasmada, a estória trata de uma chuva suspensa que se recusa a cair, ficando pasmada, no sentido de lenta, semelhante à personagem-narradora chamada de pasmado pelos pais, por ser "lento no fazer, demorado no pensar", sem "vocação para ser". A ausência da chuva era equivalente à ausência da vida. Isso se confirma no final da estória quando o pai passa a ser qualificado como pasmado, por "ter estancado junto à vida", desistido de viver, entretanto mostra que o falir do viver não vem de ter se dedicado e se enjaulado a vida toda no trabalho das minas, porque "todo homem, afinal, está sempre saindo de um subterrâneo escuro", mas

${ }^{507}$ ELIADE, Mircea. Tratado de história das religiões. São Paulo, Martins Fontes, 1993. p.153. 
porque se fechara nele mesmo. A solução apontada seria: "sair de dentro de si, arregaçar as mangas e os braços, arregaçar a alma inteira e tomar a dianteira sobre o destino."508 Em outras palavras, isso pode sugerir que Moçambique não pode se fechar em sua tradição, necessita deixar-se molhar pelas águas da modernidade, pois elas germinarão uma nova ordem, fecundarão uma nova forma de estar no mundo aberta às necessárias transformações.

Essa nova ordem só poderá advir pelo reacender do sentimento afetivo, pela experiência do amor: amor a si, amor ao outro, amor à comunidade, amor à nação. $\mathrm{A}$ chuva-sêmen seria o elemento capaz de fazer semear o sentimento amoroso e entrelaçar as pessoas: "o amor não é a semente. O amor é o semear" ${ }^{509}$. Esse fluxo afetivo, engravidado pela esperança e pelo sonho traduzem-se na imagem da água, que cai em forma de chuva, provocada pela ponte estabelecida entre a chuva e o rio. Essa ponte foi feita pela canoa na viagem do avô pelo fio líquido do tempo, "esse

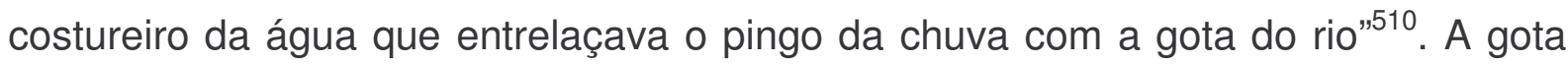
da chuva é o sêmen que vem fecundar, e o rio são as águas em fluxo, as possibilidades transformadoras que só o tempo é capaz de doar. Também, aqui, justifica-se a maneira afetiva com que Mia Couto opera a língua, tal como apresentamos anteriormente.

Como sinal de regeneração, a água participa do ritual, conferindo nova identidade: "Essa água nua, acabada de nascer, ele a fez tombar sobre mim. Como se me tivesse dando um novo nome." 511

A água, que se faz chuva, rio, mar, consagra a vida das pessoas e as coloca em permanente processo de renovação:

Ainda hoje meus pés se arrastam nessa travessia do rio, olhar perdido na outra margem. Meus passos se vão tornando líquidos, perdendo matéria, diluindo se o azul da correnteza. Assim se cumpre, sem mesmo eu saber, a intenção de meu velho avô: ele queria o rio sobrando da terra, vogando em nosso peito, trazendo diante de nós as nossas vidas de antes de nós. Um rio assim, feito só para existir, sem outra finalidade que

\footnotetext{
${ }^{508}$ COUTO, Mia. A chuva pasmada. Lisboa, Editorial Caminho, 2004. p.69.

${ }^{509}$ Idem, ibidem. p.70.

${ }^{510}$ Idem, ibidem. p.72.

${ }^{511}$ Idem, ibidem. p.73.
} 
riachar, sagradeando o nosso lugar. Como ele sempre dissera: o rio e o coração: o que os une? O rio nunca está feito, como não está o coração. Ambos são sempre nascentes, sempre nascendo. Ou como hoje escrevo: milagre é o rio não findar mais. Milagre é o coração começar sempre no peito de outra vida. ${ }^{512}$

Isso confirma não ser "o morrer que é para sempre. O nascer que é para sempre" ${ }^{\prime 13}$. Novamente, morte e vida se alternam, compondo o movimento infinito que é a existência.

Em Mar me quer, o mar é o "lugar grande", que carrega a possibilidade do sonho e do futuro: "o mar levava era os meus sonhos a passear. E eu ficava cego para as lembranças, sempre recém-nascente." 514 Em Vozes Anoitecidas, o mar também remete ao sonho: "Habitante único da tempestade, Bento João Mussavele foi seguindo mar adiante, sonho adiante." 515

O mar, também, liga-se à vida, da mesma forma que o sangue: "mar e sangue, sangue e mar. De onde vinham esses sinais?" ${ }^{16}$ E esse universo aquático, impulsionador de transformações está dentro de cada um, como se lê em: "trazemos oceanos circulando dentro de nós? Que há viagens que temos que fazer só no íntimo de nós?"517 A mudança começa dentro de cada um, e a partir daquilo que se traz, da própria história.

Em Um rio chamado tempo, uma casa chamada terra, é nas águas do rio 'Madzimi' que Mariano busca suas origens e seu passado, mergulhando em suas memórias da infância. A partida do avô ocorre no "barquito desabandonado" que o conduz, pelo rio do tempo, ao encontro com seus antepassados. Assim como as águas orientam-se ao futuro e ao sonho, elas brotam de uma fonte, de uma nascente que precisa ser redescoberta. Dessa maneira, em perpétuo escoamento, da foz ao mar, o rio faz seu curso, assim como o homem, em permanente fluir, constrói sua existência entre o passado e o vir-a-ser. Da mesma forma Moçambique, no fluxo de sua história, renova-se, continuamente, com as gotas da tradição e o sêmen da modernidade.

\footnotetext{
${ }^{512}$ COUTO, Mia. A chuva pasmada. Lisboa, Editorial Caminho, 2004. p.74.

${ }^{513}$ Idem, ibidem. p.70.

${ }^{514}$ COUTO, Mia. Il. João Nasi Pereira. Mar me quer. 5.ed., Lisboa, Editorial Caminho, 2000. p.49.

${ }_{515}$ COUTO, Mia. Vozes Anoitecidas. 8.ed., Lisboa, Editorial Caminho, 1987. p.102.

${ }^{516}$ COUTO, Mia. Il. João Nasi Pereira. Mar me quer. 5.ed., Lisboa, Editorial Caminho, 2000. p.59.

${ }^{517}$ Idem, ibidem. p.59.
} 
Esse é um projeto que se faz no fluir do tempo, ao qual também a água se associa. Em Estórias Abensonhadas, lê-se:

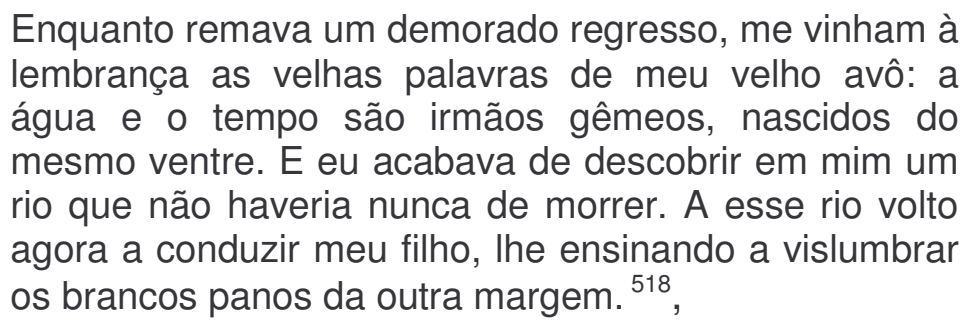

$\mathrm{Na}$ travessia do rio-tempo, torna-se possível vislumbrar uma nova terra-casa, realizando o projeto estético e político sonhado para nação moçambicana.

Para Mircea Eliade ${ }^{519}$,

\begin{abstract}
[...] qualquer que seja o conjunto religioso de que façam parte as águas, sua função é sempre a mesma: elas desintegram, extinguem as formas, "lavam os pecados", purificando e regenerando ao mesmo tempo. O seu destino é preceder a criação e reabsorvê-la, não podendo nunca superar sua própria modalidade, isto é, não podendo manifestar-se em formas. As águas não podem superar a condição do virtual, dos germes e dos estados latentes. Tudo que é forma se manifesta acima das águas, destacando-se das águas.
\end{abstract}

No caso de Moçambique e de muitas das culturas africanas, vive-se, historicamente, um momento em que a tradição, enraizada na terra, reclama, insistentemente, pela permanência, mediante os incessantes apelos do progresso e da modernidade. Entretanto, essa luta entre o velho e o novo ainda não assumiu uma forma, portanto se justifica essa simbologia aquática que povoa o imaginário do escritor e que ele busca partilhar com seus leitores. Interessante ouvir a voz de Curozero Muando, de Um rio chamado tempo, uma casa chamada terra:

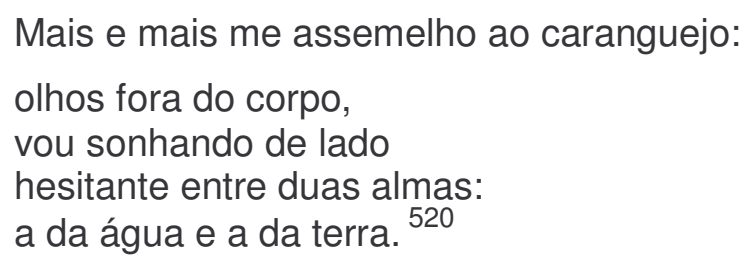

${ }^{518}$ COUTO, Mia. Estórias Abensonhadas. 2.ed., Lisboa, Editorial Caminho, 1998. p.14.

${ }^{519}$ ELIADE, Mircea. Tratado de história das religiões. São Paulo, Martins Fontes, 1993. p.173.

${ }^{520}$ COUTO, Mia. Um rio chamado tempo, uma casa chamada terra. São Paulo, Companhia das Letras, 2003. p.185. 
Moçambique vivencia, simbolicamente, um momento de travessia. Ali, deve nascer um novo homem, que não deverá ser o velho, cristalizado na tradição, na terra sólida, nem só o novo, emaranhado na modernidade, mas, uma síntese de ambos, um outro, já latente e fecundado pela força das águas.

A nova nação, a ser construída por esse novo homem, é metaforizada por uma imagem simbólica que sintetiza a terra e a água: a ilha. Essa imagem resume o sonho diurno de Mia Couto. Retomando Benjamin Abdala Junior ${ }^{521}$, "é o sonho de quem procura novos horizontes, sonhando com o futuro". Nessa imagem da ilha, sintetiza-se o projeto político e estético de Mia Couto - a ser comentado a seguir.

\subsubsection{A ilha como síntese}

Como pedaço de terra circundado pelas águas, a ilha é síntese dos dois elementos simbólicos - a terra e a água. Enquanto a água é portadora de germes, a terra dá frutos, pois seu destino é gerar incessantemente, "é dar forma e vida a tudo que volta para ela inerte e estéril. As águas encontram-se no começo e no fim de todo acontecimento cósmico; a Terra encontra-se no começo e no fim de toda vida." ${ }^{252}$ Enquanto as águas precedem toda criação e toda forma, a terra produz formas vivas.

Como espaço mítico, a ilha é imagem do Cosmos, completa e perfeita, segundo Jean Chevalier e Allain Gheerbrant ${ }^{523}$. Não é por acaso que utopia, de Thomas More, é uma ilha representativa do não lugar. A República de utopia, criada pelo autor, é lugar agradável em que não existe fome, nem falta de moradia, é lugar da igualdade.

Misto de refúgio e utopia, lugar do isolamento e da concentração, metaforizando o centro, "centro espiritual primordial"524, a ilha é local a que se chega depois de uma navegação ou de um vôo - e é nessa condição que está Moçambique, reinventando-

${ }^{521}$ ABDALA JR., Benjamin. De vôos e ilhas: literaturas e comunitarismos. São Paulo, Ateliê Editorial, 2003. p.18.

${ }^{522}$ ELIADE, Mircea. Tratado de história das religiões. São Paulo, Martins Fontes, 1993. p.206.

${ }^{523}$ CHEVALIER, Jean et GHEERBRANT, Allain. Dicionário de símbolos: mitos, sonhos, costumes, gestos, formas, figuras, cores, números. Trad. Vera da Costa e Silva et al. 10.ed., Rio de Janeiro, José Olympio, 1996.

${ }^{524}$ Idem, ibidem. p.501. 
se, na confluência de sua história vivida e de sua história sonhada. Como se observa em O último vôo do flamingo:

O que sonhei até doeu. Tanto que acordei com o peito sufocado. Pedaços do sonho se misturavam com lembranças. Tudo aos bocados, misturado. Não explodira eu, rebentara meu sonho. Eis o que restara, entre lembrança e delírio, nessa noite: nesse sonho eu estava sentado no morro de muchém, o último lugar do mundo. À minha volta tudo era água, transbordação de todos os rios. O morro era a única ilha em todo o horizonte. Ali e além se espetavam copas de árvores. Só nesses píncaros as aves encontravam pouso.

Posto assim, escanchado sobre o monte formigueiro recordava a minha vida privada. O final de minha vida era, afinal, um regresso aos meus primórdios. Porque, ali onde me terminava, o último lugar do mundo, tinha sido o primeiro local da vida. Eu estava fechando um ciclo. Tinha sido num morro como aquele que minha mãe enterrara a placenta que, durante nove meses, fora meu embrulho. Essa minha primeira manta foi sepultada no lado poente de um morro como aquele. É uma certeza, em Tizangara: a termiteira é o umbigo da terra. E nós habitáramos sempre junto de um enorme morro de muchém. Ali, por detrás do creiro que meu pai sugeria para fugir do fim do mundo, ali se erguia ele em desafio dos tempos. O morro de muchém fora um centro de minha existência. ${ }^{525}$

O sonho individual torna-se sonho coletivo. A imagem da ilha - morro de muchém - corresponde a um centro do mundo, lugar sagrado, um Cosmos, que emerge como um novo universo, nascido da mistura terra e da água, das lembranças e o delírio, das memórias e dos desejos de vir-a-ser. Uma nova vida ali se gesta, fruto de um novo conhecimento, tecido com grande esforço, em decorrência das lutas e guerras vividas por toda a comunidade - seu verdadeiro ritual de iniciação. A imagem da ilha, como síntese dessas experiências difíceis, constrói-se como um território firme em que reina uma nova forma de consciência.

É desse ritual de iniciação e de passagem que trata Mia Couto com sua escritura irreverente, não se furtando em denunciar a opressão sofrida por seu povo, em uma nação que, a todo tempo, procura se renovar, lavando, com as águas primordiais, não só seus olhos embaçados pela alienação, como também suas almas manchadas pela história. Por meio da marca verbal, aponta para um mundo grávido de possibilidades: a ilha - o último lugar do mundo torna-se o primeiro.

${ }^{525}$ COUTO, Mia. O último voo do flamingo. São Paulo, Cia das Letras, 2005. p.207. 
A Ilha de Moçambique, historicamente, ponto de cruzamento entre civilizações e culturas diversas, antes mesmo da chegada dos portugueses que ali aportaram com Vasco da Gama, em uma escala da sua demanda do caminho marítimo para a Índia, precisa olhar para dentro de si mesma, encontrar-se com suas raízes para poder projetar-se inteira no futuro.

Ao evocar a imagem da ilha, morro de muchém ou mesmo Luar-do-chão, Mia Couto traz à consciência a necessidade de alinhavar as duas pontas da história: o passado, engendrado na tradição, e o futuro, fabricado na modernidade, de forma a fazer com que o embricamento desses tempos, neste primeiro e último espaço, que é a ilha, seja capaz de forjar um novo conhecimento e um novo homem moçambicano.

É isso que testemunha o leitor, sensível e atento, ao se lançar, em travessia, pelas águas revoltas a que Mia Couto o submete. No "sobedesce" das ondas, não encontra centro. No entretempo da passagem, apenas percebe contínuo e intenso movimento. Assim, à imagem do próprio autor, o leitor enxerga-se como ser de fronteira, habitando um entrelugar. Ali, compartilha do antigo e do novo, da tradição e da modernidade, reúne memória e sonho, ordinário e extraordinário, real e fantástico, vozes e letras, morte e vida.

Na travessia iniciática, surge, a seu alcance, esta nova visão: a ilha, espécie

de varanda do mar. É ela que faz mover a estrada e empurrar os remos, de modo que ele se acomoda ao lado do narrador do segundo caderno de Kindzu e, com ele, compartilha do sagrado: "Assim, peguei a canoa e, ao acaso, puxei viagem ondas adentro. Olhei o fundo escuro da noite, lá onde o mar toca os pés de Deus. Deixei os olhos nesse infinito, fosse ali que o céu se senta sobre a terra [...]."

\subsection{A magia da voz para transcender}

Mia Couto transita entre gêneros literários, mesclando a tradição narrativa autóctone com modelos consagrados pela ficção ocidental.

A poesia apresenta-se como um campo menos explorado pelo escritor, compondo-se como momentos poéticos que rompem com a característica panfletária

${ }^{526}$ COUTO, Mia. Terra Sonâmbula. 8.ed., Lisboa, Editorial Caminho, 2004. p. 45. 
da poesia moçambicana da época pós-independência. É o que constatamos em Raiz de Orvalho e outros poemas, publicado em 1983. Em 1986, ouvem-se os ruídos mágicos dos 'Karingana ua Karingana' - fórmula inicial dos contos maravilhosos, em Vozes Anoitecidas, obra que, na visão de Fernanda Cavacas ${ }^{527}$, é o verdadeiro acontecer do escritor. Há, também, crônicas (reunidas em Cronicando), publicadas e bastante lidas nos jornais da cidade, além de uma novela - Mar me quer. Além disso, o premiado escritor africano tem publicado romances, como: Terra Sonâmbula, A Varanda do Frangipani e O último voo do flamingo. Apesar de utilizar esse gênero - símbolo da racionalidade e da modernidade, "da recusa da oralidade das tradições antigas" 528 _, faz entrever nele os fios da tradição. Ao reunir valores da terra e do progresso, enlaçando as raízes da ancestralidade com os frutos da modernidade, Mia Couto faz uma literatura de síntese entre as duas tendências: o tradicional e o moderno.

Em suas obras de diversos gêneros, o escritor revela seu compromisso com a memória narrativa e oralizante dos griots e com toda a história do continente africano, que tem, na arte milenar de contar estórias, sua base de sustentação.

Abiola Irele ${ }^{529}$ afirma que, apesar das transformações provocadas pela escrita na África, seu paradigma continua a ser a oralidade.

Despite the undoubted impact of print culture on African experience and its role in the determination of new cultural modes, the tradition of orality remains predominant, serving as a central paradigm for various kinds of expression on the continent [...] In this primary sense, orality functions as the matrix of an African mode of discourse, and where literature is concerned, the griot is its embodiment in every sense of the word. Oral literature thus represents the basic intertex of African imagination. ${ }^{530}$

527 CAVACAS, Fernanda. Mia Couto: Acrediteísmos. Lisboa, Mar Além Edição de Publicações, 2001. p.14.

${ }^{528}$ ZUMTHOR, Paul. A letra e a voz: a "literatura" medieval. Trad. Amálio Pinheiro e Jerusa Pires Ferreira. São Paulo, Companhia das Letras, 1993. p. 266.

${ }^{529}$ IRELE apud LEITE, Ana Mafalda. In: Revista Via Atlântica. n 8. São Paulo, Departamento de Letras Clássicas e Vernáculas, Faculdade de Filosofia, Letras e Ciências Humanas, Universidade de São Paulo, 2005. p.154.

530 “Apesar do indubitável impacto da cultura escrita na experiência africana e seu papel na determinação de um novo modelo cultural, a tradição oral permanece predominante, servindo como paradigma central para vários tipos de expressão no continente. Em seu sentido primeiro, a oralidade funciona como a matriz de um modo de discurso africano e, no que diz respeito à literatura, é sua personificação no verdadeiro sentido da palavra. A literatura oral, portanto, representa o intertexto básico da imaginação africana". 
A cultura oral de que Moçambique é tributária, funda-se em vivências marcadas por uma produção artesanal. Nesse modelo de cultura, o conhecimento é repetido para não se perder, daí a importância dos velhos - guardiões das experiências coletivas e do passado. Cumpre lembrar Walter Benjamin ${ }^{531}$, ao enfatizar que a experiência narrada é a que se relaciona com o coletivo (erfahrung), inscrita em uma temporalidade comum, implicando uma tradição compartilhada e não individual (erlebnis = vivência). Por isso, sua base é a memória. O narrador extrai a matéria narrável de sua própria experiência ou da experiência relatada pelos outros e a incorpora à experiência dos seus ouvintes. Sua palavra, portanto, tem força de ofício.

Considerado um artesão, o narrador é criador dos fios da vida, capaz de coordenar a alma, o olhar e a mão no gesto do narrar. Seu desenho se faz com palavras, sua matéria-prima é a vida humana, a experiência do homem, a sua e a dos outros, e seu instrumento é a voz. Mestre ou sábio, o narrador sabe dar conselhos, visto que possui o acervo de uma vida. Tornando interpretável o que vive, ele marca sua narrativa como a mão do oleiro na argila do vaso, verso-barro.

A atmosfera que circunda essa palavra-arte é sagrada. A voz é mensurada entre os sons da natureza: pelo corpo do qual emana, pela música que pronuncia. Essa voz-experiência reúne o intérprete e a audiência em um instante único - o da 'performance', como afirma Zumthor ${ }^{532}$. Para ele, a 'performance' define-se como ação por meio da qual a mensagem poética é simultaneamente percebida e transmitida. Há um dizer por meio da voz e do corpo que narra, e uma escuta por parte do público que vê o contador. Tempo, lugar e pessoas são os elementos responsáveis pela 'performance'. Não se tratando de uma voz que apenas pronuncia, ela torna presente o acontecido por meio do qual o ouvinte se descobre. Uma estória ancestral é memorizada e transmitida por meio de uma individualidade que a anima em um determinado instante. O momento da narração instaura um cosmos pleno de solidariedade, afetividade, regado de um maravilhoso impossível de ser conferido pela razão. A matéria narrável é sempre a vida humana e seus

\footnotetext{
${ }^{531}$ BENJAMIN, Walter. Magia e técnica, arte e política: ensaios sobre literatura e história da cultura. Trad. Sérgio Paulo Rouanet. 7. ed., São Paulo, Brasiliense, 1994. (Obras Escolhidas, 1). p. 201.

${ }^{532}$ ZUMTHOR, Paul. A letra e a voz: a "literatura" medieval. Trad. Amálio Pinheiro e Jerusa Pires Ferreira. São Paulo, Companhia das Letras, 1993.
} 
complexos enigmas. Espontaneidade, simplicidade, afetividade, sacralidade, são aspectos característicos desse momento mágico.

Nas culturas fundadas na tradição oral, como são as africanas, o olho está subordinado ao ouvido. É a audição que orienta as experiências profundamente marcadas pela sociabilidade e pela solidariedade humana. De garganta a garganta, o discurso renova sua força vital. Da boca ao ouvido, a palavra grávida de transcendência, não morre nunca.

O encontro do narrador com o ouvinte promove uma experiência de saída do tempo e do espaço ordinários, aliada a uma imersão em um espaço e em um tempo extra-ordinários. O lugar da narração torna-se, dessa forma, um espaço de criação como um Centro do Mundo, no qual se realiza um ritual de iniciação (sintonia e equivalência do sopro vital/da fecundação do verbo com a experiência narrativa).

Em consonância com Laura Cavalcanti Padilha ${ }^{533}$, do ponto de vista da produção cultural, contar estórias é uma prática ritualística, "um ato de iniciação ao universo da africanidade".

Em O último voo do flamingo, Mia Couto ${ }^{534}$ faz uma dedicatória em que se observa a relação do narrar com o ato sagrado: "À Joana Tembe e ao João Joãoquinho, que me contaram estórias como quem rezava”.

O portador da palavra apresenta-se como um ser aurático, continua a teórica:

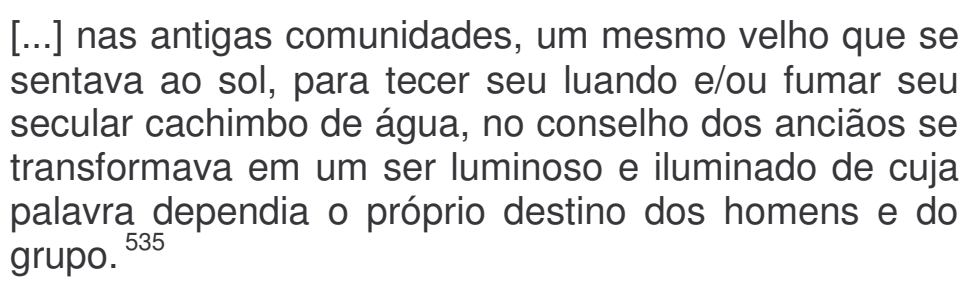

Mia Couto, ao bordar em letras os tons da voz, leva o leitor à entrevisão transcendente desse mundo narrável pela memória. Assim, vai colorindo de sagrado as malhas do profano, criando um espaço ficcional híbrido em que a magia da voz e a artesania da letra cumprem seu papel de elevar o homem aos desígnios divinos do encantamento.

\footnotetext{
${ }^{533}$ PADILHA, Laura Cavalcanti. Entre voz e letra: o lugar da ancestralidade na ficção angolana do século XX. Rio de Janeiro, EDUFF, 1995. p.15.

${ }_{534}^{534}$ COUTO, Mia. O último voo do flamingo. São Paulo, Cia das Letras, 2005.

${ }^{535}$ PADILHA, Laura Cavalcanti. Op. Cit. p.16.
} 
Resgatando Laura Cavalcanti Padilha ${ }^{536}$, "pela letra que tudo eterniza, tais estórias, ao invés de circularem apenas pela voz, muitas vezes se perdendo nos desvãos da noite, ganham a claridade do texto escrito e um corpo - o do livro - que se thes oferece como espaço de iniciação“.

Nesse propósito, percebemos que Mia Couto faz questão de gestualizar o texto, de griotizar a expressão narrativa, recuperando, no ato solitário da leitura, o ato solidário da narração oral.

Confessa o autor que escreve para se "familiarizar com os deuses". Aliás, sua infância ocorreu em um ambiente de mestiçagem, ao redor dos contadores de estórias, que Ihe traziam "o encantamento de um momento sagrado"537. Ao questionar sobre os autores daquelas narrativas, descobria que a origem eram os antepassados, firmando-se como herança dos deuses. E os antepassados estavam ali naquele chão convertidos em entidades divinas.

Devido ao culto à ancestralidade, a velhice, na cultura moçambicana, é uma etapa da existência humana a que todos aspiram, pois a crença na sobrevivência após a morte privilegia os anciãos - vínculo entre os vivos e os mortos. Em $O$ último voo do flamingo, nota-se esse valor conferido ao velho, à experiência narrável entre as gerações, inclusive dos mortos aos vivos:

- Outra coisa: o senhor pergunta de mais. A verdade foge de muita pergunta.

- Como posso ter respostas se não pergunto?

- Sabe o que devia fazer? Contar a sua estória. Nós esperamos que vocês, brancos, nos contem vossas estórias.

- Uma estória? Eu não sei nenhuma estória.

- Sabe, tem que saber. Até os mortos sabem. Contam estórias pela boca dos vivos. ${ }^{538}$

Enquanto o branco, mobilizado pelos valores ocidentais da informação, faz perguntas, o negro conta estórias, trazendo respostas em forma de experiênciasimagens. Este as conta, como ensina a tradição: com a voz do velho ao centro, à

\footnotetext{
${ }^{536}$ PADILHA, Laura Cavalcanti. Entre voz e letra: o lugar da ancestralidade na ficção angolana do século XX. Rio de Janeiro, EDUFF, 1995. p. 197.

${ }^{537}$ COUTO, Mia. Pensatempos: textos de opinião. 2. ed., Lisboa, Editorial Caminho, 2005. p.150.

${ }^{538}$ COUTO, Mia. O último voo do flamingo. São Paulo, Cia das Letras, 2005. p.106.
} 
noite, na mata, em círculo, no calor do fogo e do sonho, como se pode observar nas duas passagens a seguir, retiradas de duas outras obras literárias do autor:

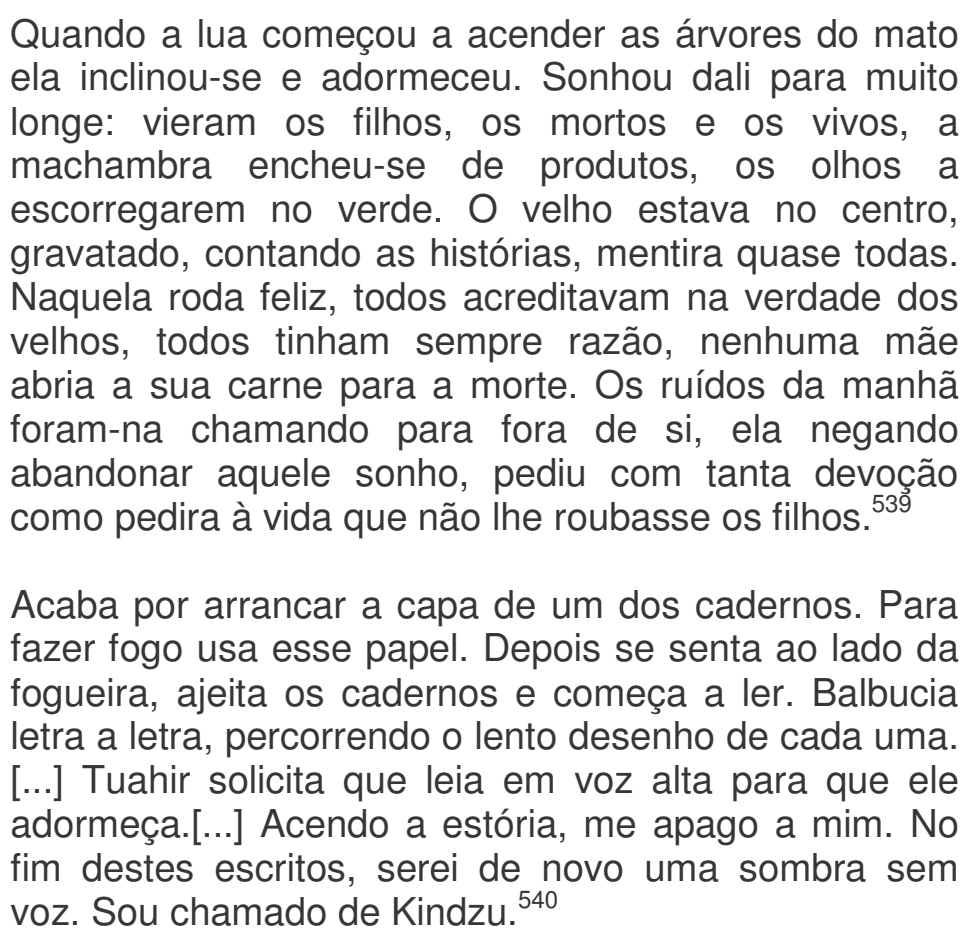

Nessa cena em que o menino Muidinga resolve acender uma fogueira, rasgando a capa do caderno, observamos a necessidade de aquecer com o calor da voz a frieza da letra. E retornar o tempo em que a estória era contada por uma voz sem dono. Assim, Mia Couto insere, no texto literário, os sinais anônimos da tradição oral, fazendo conviver um narrador de letra e outro de voz, um profano e outro sagrado.

Por meio desse encontro mágico no território do livro, Mia Couto tece a história da resistência. Velho e novo confrontam-se e, ao mesmo tempo, alimentamse. 'Griot' e escritor discutem e se abraçam, tradição e modernidade, em luta, enredam-se.

Nas ressonâncias da voz, as formas da tradição, as formas simples - mitos, lendas, adivinhas, provérbios, contos - alinhavam-se em desenho de letra, fazendo circular o acervo simbólico-imaginário e a mundividência mágico-mítica que funda a cultura africana.

\footnotetext{
${ }^{539}$ COUTO, Mia. Vozes Anoitecidas. 8.ed., Lisboa, Editorial Caminho, 1987. p. 27.

${ }^{540}$ COUTO, Mia. Terra Sonâmbula. 8.ed., Lisboa, Editorial Caminho, 2004. p.15-17.
} 
Ao escolher a modalidade narrativa como gênero e o conto - sua marca mais inventiva - como forma literária predominante, o autor africano reacende, de maneira fecunda e transformadora, a palavra mágica do contador, fazendo entrever as feições de uma sociedade tradicional para a qual o gesto vocal é portador de uma força sagrada que enlaça os homens, na medida em que recompõe a memória. Essa escolha apresenta-se como uma espécie de libertação afetiva. Se gênero e forma constituem instrumental de expressão de mundividências, como afirma Massaud Moises $^{541}$-, a prosa narrativa em forma de conto é, para Mia Couto, seu principal agente transformador.

Cumpre relembrar Andre Jolles ${ }^{542}$, ao citar Grimm, para elucidar a diferença existente entre a forma artística, cuja característica é a elaboração, e a forma simples, cuja qualidade é ser criação espontânea:

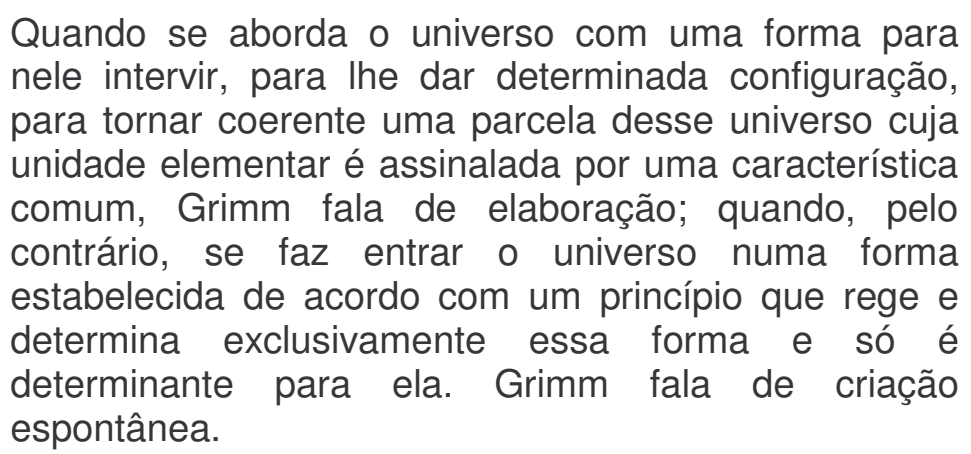

O conto artístico de Mia Couto, atualizando sua forma simples, traz como características a brevidade, as personagens como seres humanos, animais humanizados ou seres sobrenaturais, dentro de um universo maravilhoso. Quanto à linearidade, observamos rupturas que acenam para o moderno.

Por guardar relações com a oralidade, o conto literário vale-se de repetições, de onomatopéias recuperadoras dos ruídos naturais da narração tradicional, suas orações são curtas, absolutas em geral e, no período composto, predominam orações coordenadas, favorecendo o contato mais espontâneo e a comunicação mais rápida com o receptor. Além disso, não há muita descrição, mas existe bastante diálogo, conferindo forma dramática ao texto, trazendo a memória da 'performance'. O narrador de voz e seu duplo na escrita, o narrador de letra,

\footnotetext{
${ }^{541}$ MOISES, Massaud. Literatura: mundo e forma. São Paulo, Cultrix, Edusp, 1982. p. 266.

${ }^{542}$ JOLLES, André. Formas Simples: legenda, saga, mito, adivinha, ditado, caso, memorável, conto, chiste. Trad. Álvaro Cabral. São Paulo, Cultrix, 1976. p. 194.
} 
ocupam-se mais com as ações e as personagens, a fim de resgatar o movimento da voz na aparência estática da letra. É com artesania que a letra se entrega à magia da voz, a forma artística ressoa a forma simples, levando o leitor a rememorar um ritual comunitário e solidário primeiro.

Eleger o conto como forma privilegiada de seu projeto estético e político é, no dizer de Laura Cavalcanti Padilha ${ }^{543}$, "uma forma ancestral de resgate simbólico da história". Essa proposta de fecundar o gesto vocal, o passado e seus referenciais autóctones traduzem, nos terrenos da letra, a expectativa de retecer a história vivida nas malhas da estória sonhada, buscando atestar, na "sociedade do ter", a permanência de uma "sociedade do ser", para relembrar Paul Zumthor ${ }^{544}$.

A escrita, para Mia Couto ${ }^{545}$, "não se resume ao momento em que deitamos palavras para um papel. A escrita é todo um modo de estar, de viver com atenção o lado invisível do cotidiano. Implica uma relação de criatividade que se mantém com os outros e com o mundo". Para ele, o conto assim se define:

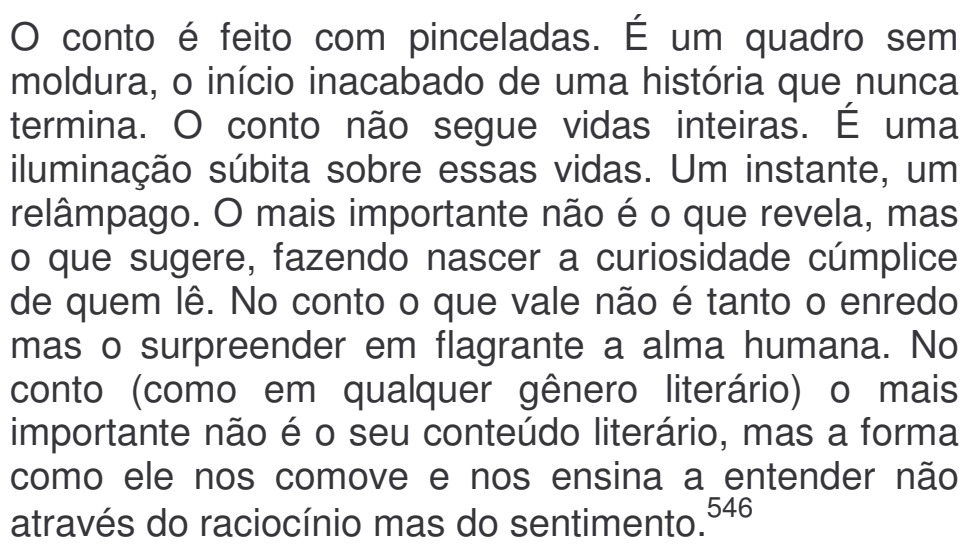

Diante dos tristes sinais históricos da modernidade, capturados na vida vivida e revelados, ficcionalmente, na fala de Nãozinha, como uma iluminação súbita -

${ }^{543}$ PADILHA, Laura Cavalcanti. Entre voz e letra: o lugar da ancestralidade na ficção angolana do século XX. Rio de Janeiro, EDUFF, 1995. p. 33.

${ }^{544}$ Segundo Zumthor: Ser "moderno" é julgar homens e coisas em virtude do que eles têm ou do que lhes falta; é conhecer seus atributos a fim de domar-lhes o uso. Ser "antigo" [...] é conhecer e julgar em virtude do ser e do nada. Pelo que concerne à poesia, a escritura parece moderna; a voz, antiga. Mas a voz "moderniza-se" pouco a pouco: ela atestará um dia, em plena "sociedade do ter", a permanência de uma "sociedade do ser". (ZUMTHOR, Paul. A letra e a voz: a "literatura" medieval. Trad. Amálio Pinheiro e Jerusa Pires Ferreira. São Paulo, Companhia das Letras, 1993. p.26).

545 COUTO, Mia. In: Revista Via Atlântica. n 8. São Paulo, Departamento de Letras Clássicas e Vernáculas, Faculdade de Filosofia, Letras e Ciências Humanas, Universidade de São Paulo, 2005. p. 216.

${ }^{546}$ COUTO, Mia. Pensatempos: textos de opinião. 2.ed., Lisboa, Editorial Caminho, 2005. p.46. 
"Nãozinha se lamentava: quem nos mandou afastar das tradições? Agora, perdemos os laços com os celestiais mensageiros." ${ }^{547}$-, a única saída é amarrar a magia da voz na artesania da letra. Por isso, em seu projeto de reinvenção de uma nova maneira de estar no mundo, Mia Couto não perde de vista o sagrado.

Apresentamos até aqui alguns traços singularizadores do projeto político e estético de Mia Couto. Faremos, a seguir, uma leitura de 0 gato e o escuro ${ }^{548}$, com o intuito de analisar como os elementos sagrados se articulam no todo da obra, tanto em linguagem verbal quanto em linguagem visual. Esse conto representativo da força criativa do autor será, posteriormente, cotejado com Poeminhas pescados em uma fala de João, de Manoel de Barros, já analisado anteriormente.

\subsection{O Gato e o Escuro}

Com o livro O Gato e o Escuro, o premiado escritor moçambicano estréia no mundo da literatura infantil e nos convida a "despersianar os olhos" por meio de uma travessia sagrada, capaz de enredar tanto os grandes, quanto os pequenos.

$\mathrm{Na}$ fronteira entre o dia e a noite, entre a luz e o escuro, um gato curioso e corajoso realiza uma travessia-transgressão, atraído não só pelo mistério ou pelo proibido, mas, também, pela vontade de descoberta. O protagonista alimenta sonhos que o aproximam do Escuro: outro ser, personagem-faceta formadora de sua identidade.

O conto inicia com a magia da voz de um narrador primordial ${ }^{549}$ - portador de uma autoridade e guardião da memória dos acontecimentos - alinhavado em um

\footnotetext{
${ }^{547}$ COUTO, Mia. A varanda do frangipani. 7.ed., Lisboa, Editorial Caminho, 2003. p. 140.

${ }^{548}$ COUTO, Mia. Il. Danuta Wojciechowska. O gato e o escuro. 8. ed., Lisboa, Editorial Caminho, 1987.

${ }^{549}$ Segundo Nelly Novaes Coelho, o narrador primordial é o "que se transformou em contador-deestórias, (alguém que não se apresenta como autor, não inventou os fatos narrados, mas presenciou-os ou soube deles por alguém, guardou-os na memória e os conta para outros). Isso pode ser observado pelas expressões: "Conta a mãe dele"; "Diz-se que ficou dessa maneira".(COELHO, Nelly Novaes. Literatura infantil: teoria, análise e didática. 6.ed. rev., São Paulo, Ática, 1993. p.66).
} 
moderno narrador dialético ${ }^{550}$, que, em conversa com o leitor, apresenta o acontecimento extraordinário.

\begin{abstract}
Vejam, meus filhos, o gatinho preto, sentado no cimo desta história. Pois ele nem sempre foi dessa cor. Conta a mãe dele, que, antes tinha sido amarelo, às malhas e às pintas. Tanto que the chamavam Pintalgato. Diz-se que ficou desta aparência, em totalidade negra, por motivo de um susto. Vou aqui contar como aconteceu essa trespassagem de claro para escuro. O caso, vos digo, não é nada claro.
\end{abstract}

Ao se estreitar a relação entre contador-narrador e público-leitor, forja-se uma situação similar à 'performance ${ }^{, 551}$, aproximando a leitura de um ato mais solidário do que solitário. Isso pode ser evidenciado pelo uso de perguntas que estabelecem diálogo com o leitor - "Que aconteceu?", "Adivinham?" - que, aliadas ao discurso direto, expressam na escrita os efeitos da voz e do gesto. Expressões próprias da narração oral - tais como "Conta a mãe dele que", "Diz-se que", "Vou aqui contar como aconteceu", "O caso, vos digo", "Aconteceu assim", "Faz de conta” "Certa vez", "Então" - são empregadas para fazer o leitor sentir a presença do gesto e do corpo do narrador.

O uso de alguns verbos no presente - "Vejam", "Conta", "Diz-se", "vos digo", "Faz de conta", "Adivinham" - confere a sensação da instantaneidade que caracteriza a 'performance', diferenciando o tempo do contar do tempo do contado.

Com isso, percebe-se que o contador se vale da memória para contar a experiência extraordinária vivida pela personagem Pintalgato. Ao comunicá-la, ela passa a ser, também, a experiência do leitor, que, aderido ao gato, na travessia das páginas do livro, perfaz seu caminho iniciatório. Pela palavra-força, o leitor recria a experiência do outro e torna interpretável a sua.

Vale destacar que o conselho é sugerido não na forma didática ou moralista, como em geral ocorre nas narrativas da tradição, mas lhe é dado em forma de sabedoria revelada pela própria construção estética.

\footnotetext{
${ }^{550}$ Ainda segundo a teórica, o narrador dialético é tipo mais recente, identificado como uma "voz que se dirige a um tu, a uma segunda pessoa, que permanece sempre silenciosa". Comenta a autora que esse tipo de narrador é bastante rico para a criança por abrir-lhe espaço para reflexão.

${ }^{551}$ Cumpre ressaltar que, apesar de serem recuperados vários elementos da 'performance' no texto escrito, a cultura livresca guarda suas diferenças, pois a presença física inexiste, ela é apenas sugerida.
} 
A oralidade característica da 'performance' e das narrativas da tradição apresenta-se no texto de maneiras diversas.

Com uma estrutura narrativa cíclica, o narrador abre possibilidade de repetição. O leitor é convidado a ir e a voltar na estória. Esse movimento é marcado, na linguagem verbal, pela fala inicial do narrador - "Vejam, meus filhos, o gatinho preto, sentado no cimo desta história. Pois ele nem sempre foi dessa cor." - e pela fala final - "Então, o gatinho Pintalgato espreitou nessa fenda escura como se vislumbrasse o abismo. Por detrás dessa fenda o que é que ele viu? Adivinham? Pois ele viu um gato preto, enroscado do outro lado do mundo."

Ao ser repetida, a experiência não se perde e torna-se possível recuperar, de alguma maneira, a movência da tradição em que a voz é o instrumento.

Essa estruturação cíclica acaba por ritualizar o tempo e a leitura, sacralizando e satisfazendo uma necessidade humana: a do sagrado.

Para favorecer a escuta desse gesto vocal fertilizado pela transcendência e, igualmente, para trazer o texto escrito à sensibilidade da criança, Mia Couto recria ruídos por meio de onomatopéias, como "tiquetaqueava", "ronronou". Ainda na perspectiva de apresentar a língua como é percebida pela criança, um inventário aberto de possibilidades -, o escritor vale-se de neologismos, como "trespassagem", "namoriscando", pirilampejavam", "sobrancelhado", "noitidão", "despersianar", "gateza", "arco-iriscando", "estremolhado", valendo-se de mecanismos de criação oferecidos pela própria língua, como os processos de derivação, de composição das palavras.

Em seu projeto de trabalhar a oralidade criativamente, subvertendo a normapadrão para aproximá-la da criança, o autor rompe com a sintaxe estabelecida, criando outras possibilidades de expressão, como em "gostava passear-se". Ou cria períodos em que as orações não estabelecem os nexos de coesão, como: "Quando olhava o escuro, a mãe ficava com os olhos pretos. Pareciam encheram de escuro. Como se engravidassem de breu, a abarrotar as pupilas". A coerência faz-se apenas com os recursos da voz, no plano da oralidade.

Mia Couto coloca o leitor em festa com seu "brincriar", associando, ludicamente, palavras para compor outras, como em Pintalgato e "ataratonto".

Além disso, faz uso de diminutivos, como "gatinho preto" e "bocadinho", para aproximar-se, afetivamente, da criança, sem cair na puerilidade. 
A simplicidade no brincar com a língua é a mesma com que sugere ao leitor profundas reflexões sobre a complexidade da vida, como em "o escuro só existe dentro da gente". Aliás, dessa maneira, a brincadeira e a seriedade contida no jogo, em consonância com a visão de Johan Huizinga ${ }^{552}$, mostram-se aliadas.

A letra acaba por simular o jogo no qual o gesto da ação performática se atualiza. Para Paul Zumthor ${ }^{553}$, "a 'performance' é jogo, no sentido mais grave, senão mais sacral desse termo". E continua:

[...] não é divertimento senão secundariamente; ela não é em absoluto uma ocasião especificamente agradável; é comunicação de vida, sem reserva. Preenche para o grupo a função que tem o sonho para o indivíduo: liberação imaginária, realização lúdica de um desejo. ${ }^{554}$

Ao entrar no jogo da letra, que rememora o jogo da voz, imediatamente o leitor retira-se do tempo homogêneo, contínuo e profano para arrebatar-se no Grande Tempo, um tempo fabuloso, circular e sagrado.

Segundo Johan Huizinga ${ }^{555}$, "[...] reconhecer o jogo é, forçosamente, reconhecer o espírito, pois o jogo, seja qual for a sua essência, não é material. Ultrapassa os limites da realidade física”.

São características do jogo:

1. ser atividade livre;

2. não ser vida corrente;

3. realizar-se em uma esfera temporária de atividade com orientação própria;

4. ser sério;

5. ser desinteressado, porque não pertence à vida comum e a interromper;

6. ser atividade temporária, um intervalo na vida cotidiana, mas integrante da vida em geral;

7. ocorrer em um espaço delimitado de maneira material ou imaginária;

8. criar a ordem e ser a ordem, introduzindo no caos da vida, um cosmos;

\footnotetext{
${ }_{552}^{5}$ HUIZINGA, Johan. Homo Ludens. São Paulo, Perspectiva, 1996.

${ }^{553}$ ZUMTHOR, Paul. A letra e a voz: a "literatura" medieval. Trad. Amálio Pinheiro e Jerusa Pires Ferreira. São Paulo, Companhia das Letras, 1993. p.240.

${ }_{554}^{55}$ Idem, ibidem. p. 260.

${ }^{555}$ HUIZINGA, Johan. Op. Cit. p.6.
} 
9. ser necessidade, ampliando a vida. Sua função vital revela sua função cultural. Em sua qualidade de atividade sagrada, o jogo contribui para a prosperidade do grupo social.

10. absorver inteiramente o jogador, com enlevo e entusiasmo capazes de levar ao arrebatamento.

Essa última característica pode ser observada pela conjunção entre o maravilhoso, que permeia a narração e atrai a criança, e a elaboração estética, realizada por meio de figuras de linguagem, como metáforas, comparações, personificações, que enredam o leitor e levam-no ao encantamento.

As comparações são bastante recorrentes no texto, como em "Mais enrolado que pangolim"; "[...] viu brilhar as unhas, disparadas como repentinas lâminas", "Pintalgato fitou o fundo dos olhos de sua mãe, como se debruçasse num poço escuro", "Ihe surgiu como que um relâmpago atravessando a noite", "espreitou nessa fenda escura, como se vislumbrasse o abismo".

As metáforas procuram retratar o pensamento mágico e concreto da criança, como em "Por que razão o mundo se embrulhava num pano preto?"

As personificações ocorrem com o gato - animal predileto do autor e personagem principal da estória - e com o escuro. Personificação inventiva para um texto infantil, uma vez que, sendo elemento provocador de medo na criança, ao nomeá-lo, torna possível apreendê-lo e com ele dialogar.

Assim, Mia Couto vai magicamente plasmando um universo estético novo e maravilhoso, em sua forma e em seu conteúdo, capaz de encantar não só a criança, mas, também, o adulto. Incursiona o ouvinte-leitor pelos meandros das páginas para que vivencie sua travessia iniciática. Essa iniciação só pode ser experimentada porque o leitor se projeta na personagem Pintalgato e com ela é levado à viagem sagrada.

Projetar-se em um animal, exercício recorrente na literatura para crianças e jovens, é uma forma de ter contato com o sagrado.

Há muitos séculos, o animal compõe o acervo imaginário da humanidade. Em O Homem e seus Símbolos, Karl Jung ${ }^{556}$ afirma serem os animais símbolos de transcendência.

${ }^{556}$ JUNG. Carl. El hombre y sus símbolos. Barcelona, Luis de Caralt Editor, 1964. 
O simbolismo do gato é universalmente conhecido. Mostra-nos Marie-Louise Von Franz ${ }^{557}$, em sua obra $O$ Gato, que, historicamente, esse animal começou a receber os atributos de poder com os egípcios, para os quais era considerado sagrado, por ter relação com a vida espiritual do homem.

De acordo com o mito, a filha de Ísis e de Osíris, Bastet é conhecida como a deusa-gato. Muitas vezes, essa deusa se identificava com o pai. Por sua identificação com o pai, deus da vida, as pessoas acreditavam que o Sol-gato envolvia-se todas as noites com Apófis, serpente das trevas, em uma luta de proporções cósmicas. Por isso, o gato é considerado herói mitológico solar. Além disso, também é cultuado como entidade lunar. Acreditava-se que, durante a noite, período em que se ocultam os raios de sol, eles se refletiam nos olhos fosforescentes do gato, como a luz do sol reflete na lua. O texto moçambicano parece guardar, em seus elementos, semelhanças com esse mito egípcio.

Por ser resistente às quedas, é comum a crença de que o gato tem sete e até nove vidas - associando-se à idéia de imortalidade. No livro analisado, Pintalgato atravessa, com ousadia, a fronteira entre o dia e a noite, ganha as marcas do escuro e nele mergulha, como se, em exercício de introspecção, atravessasse as fronteiras até seu interior, no momento de perceber-se outro e poder sair enriquecido de sua travessia, posicionando-se no cimo da estória, podendo ser dela guardião. Ao assumir seu lugar no alto, ganha soberania de herói, eleva-se a um lugar sagrado capaz de lhe conferir aura imortal.

No Dicionário dos Símbolos de Jean Chevalier e Allain Gheerbrant, encontramos uma explicação para essa simbologia de estar no cimo, como se ocupasse o pico de uma montanha e, aqui, pretendemos registrar:

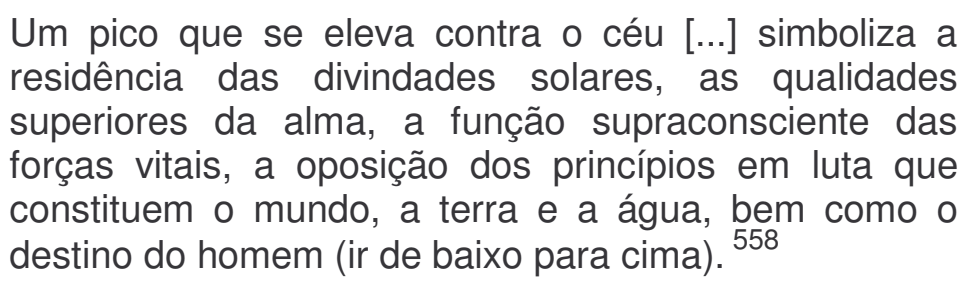

\footnotetext{
${ }^{557}$ VON FRANZ, Marie Louise. O gato: um conto da redenção feminina. São Paulo, Paulus, 2003. p.69.

${ }^{558}$ CHEVALIER, Jean et GHEERBRANT, Allain. Dicionário de símbolos: mitos, sonhos, costumes, gestos, formas, figuras, cores, números. Trad. Vera da Costa e Silva et al. 10.ed., Rio de Janeiro, José Olympio, 1996. p. 619.
} 
Como herói solar, Pintalgato mostra-se independente e livre. Como animal, é ágil, observador, desconfiado, sagaz, parece ter o poder da reflexão, da engenhosidade. Por não ficar fechado, preso sem desesperar-se, é símbolo de liberdade, jamais permanece em servidão, por isso desobedece. Aliás, desobediência é sua característica marcante - o que lhe favorece a autodescoberta e o aproxima do sonho. Conhecer destemidamente para transformar - talvez seja esse o papel político do felino em Mia Couto.

Segundo Marie-Louise Von Franz ${ }^{559}$, de acordo com uma crença agnóstica, havia, no Jardim do Éden, um gato que guardava a árvore da vida, com seu conhecimento do bem e do mal, assim como no Egito, aliava-se a uma árvore similar (do gênero Persea - árvore da vida e da consciência). Dessa maneira, atuava como mediador entre o bem e o mal, entre a vida interior e a vida exterior, entre deus e o homem. Pintalgato, no cimo da estória, traz semelhança com esse animal-guardião.

Como seus olhos não piscam e ele enxerga no escuro, diz-se que o gato tem antevisão, intuição e clarividência, o que é testemunhado pelos povos da África Central, segundo descrição de Jean Chevalier e Allain Gheerbrant ${ }^{560}$. Com seu olhar perspicaz, ele torna visível o invisível. A mãe-gata - metáfora da África originária, da terra-mãe - antecipando o que elucidaremos a seguir - abriga nos olhos toda a estória sonhada por Pintalgato, portanto ela sabe, tem o conhecimento, tem a clarividência.

É em Pintalgato que Mia Couto se projeta, não só por seu amor confesso a gatos, mas por estar o animal "ligado à consciência e aos processos criativos", de acordo com Marie-Louise Von Franz ${ }^{561}$. Para Mircea Eliade ${ }^{562}$, o gato não dorme de noite nem de dia, está sempre acordado, em vigília - ação assumida, também, pelo leitor. Tanto autor, quanto leitor compartilha dessa mesma tarefa cosmogônica, como já enunciamos anteriormente, nas páginas iniciais desta tese.

\footnotetext{
${ }^{559}$ VON FRANZ, Marie Louise. O gato: um conto da redenção feminina. São Paulo, Paulus, 2003. p.72.

${ }^{560}$ CHEVALIER, Jean et GHEERBRANT, Allain. Dicionário de símbolos: mitos, sonhos, costumes, gestos, formas, figuras, cores, números. Trad. Vera da Costa e Silva et al. 10.ed., Rio de Janeiro, José Olympio, 1996. p. 463.

${ }^{561}$ VON FRANZ, Marie Louise. O gato: um conto da redenção feminina. São Paulo, Paulus, 2003. p.71.

562 ELIADE, Mircea. Aspectos do mito. Trad. Pola Civelli. 4. ed., São Paulo, Perspectiva, 1994. p.112.
} 
Se Mia Couto tem sua preocupação criativa voltada especialmente para criação de personagens, Pintalgato e sua mãe foram brilhantemente escolhidos. Como, em seu processo criativo, o autor afirma inventar, primeiro, a personagem e, depois, uma estória para ela participar, analisaremos, a seguir, a ação e os elementos simbólicos envolvidos.

A ação da narrativa gira em torno do passeio-travessia de Pintalgato na fronteira entre o dia e a noite. Dessa viagem, participam elementos do mundo natural, como o sol e a lua. Ambos possuem papel simbólico primordial no imaginário humano.

O Sol, nos ensinamentos de Jean Chevalier e Allain Gheerbrant ${ }^{563}$, é, para muitos povos, a manifestação da divindade - epifania uraniana. Pode ser concebido como o filho de Deus supremo e irmão do arco-íris. Símbolo da ressurreição e da imortalidade, ele se põe e renasce todos os dias, irmanando os homens em seu ciclo.

Olho do mundo, fonte vital de luz e calor, o astro liga-se, simbolicamente, à civilização, às regras e princípios de autoridade e de poder, de consciência dos limites, por isso dizia a mãe de Pintalgato: "nunca atravesse a luz para o lado de lá". Sua tentativa era mantê-lo alinhado às regras civilizatórias, fundamentadas na razão.

O sol, também, é símbolo de iluminação, de conhecimento. Essa imagem aparece no momento final da narrativa quando, somente na presença da luz, Pintalgato é capaz de enxergar nos olhos da mãe-gata a sua própria estória: "Ante a luz, porém, seus olhos todos se amarelavam, claros e luminosos, salvo uma estreitinha fenda preta. [...] Por detrás dessa fenda o que é que ele viu? Adivinham? Pois ele viu um gato preto, enroscado do outro lado do mundo".

Aliado ao simbolismo solar, o texto nos traz o simbolismo lunar, compondo ambos a identidade de Pintalgato, como se percebe na passagem: "[...] antes, tinha sido amarelo, às malhas e às pintas. [...] Diz-se que ficou desta aparência, em totalidade negra, por motivo de um susto".

O simbolismo lunar alia-se à personagem Escuro, o gatinho preto que aparece sentado no cimo da estória como guardião do passado e expectador do futuro. Rica em todas as possibilidades de existência, a noite é o começo do dia,

${ }^{563}$ CHEVALIER, Jean et GHEERBRANT, Allain. Op. Cit. p.836. 
simbolizando o tempo das gestações, das germinações. Representa o caos anterior ao vir-a-ser. Sono sagrado e sonho são seus companheiros.

O escuro, propriedade da noite, é elemento desse caos, símbolo da indiferenciação, do inexistente, do desconhecido e, ao mesmo tempo, de todas as possibilidades.

A zona lunar é noturna, crepuscular, instintiva, lugar das fantasias, da imaginação e da sensibilidade profunda. A ela se entrega o ser em encantamento silencioso, refugiado no paraíso de sua infância, abandonado ao sonho, ao sabor da aventura - lugar da imaginação e da magia.

Os mitos lunares relacionam-se com a morte e a ressurreição, com a fertilidade e a regeneração, com a iniciação. Ao mesmo tempo em que a lua remete, com suas fases, à passagem do tempo, revela, também, o eterno retorno.

Esse simbolismo leva-nos a compreender que nada é estático, tudo começa de novo e é possível ser refeito a cada instante, pois "nenhum acontecimento é irreversível e nenhuma transformação é final", retomando a concepção de Mircea Eliade. ${ }^{564}$

O dia remete ao mundo da razão, das leis, das regras, enquanto a noite remete ao universo da intuição, da magia, do instinto, da sensibilidade. Portanto, no contexto histórico africano, o dia pode estabelecer relação com a modernidade, enquanto a noite pode aliar-se à tradição.

Além disso, o dia refere-se ao nascer do sol; a noite remete às trevas prénatais. O simbolismo sobre o qual se estrutura a ação narrativa remete ao ato cosmogônico e escatológico que compõe o processo de transição vivido pela África da tradição à modernidade. Ou melhor, para se construir uma nova África, a modernidade deve se revestir de tradição. É por isso que, em sua travessia, Pintalgato, se tinge de preto. A marca do Escuro passou a compor a identidade de Pintalgato no decurso de sua "trespassagem", de seu ritual de iniciação e conseqüente descoberta de si.

Essa viagem iniciatória compõe-se pela experiência da morte e de um novo nascimento, a passagem de um caos para um novo cosmos, da noite para um novo dia, travessia de uma margem a outra, de um modo de existir a um outro. Como se lê na estória:

${ }^{564}$ ELIADE, Mircea. Mito do eterno retorno. Trad. José Antônio Ceschin. São Paulo, Mercuryo, 1992. p.80. 
Fechou os olhos e andou assim, sobrancelhado, noite adentro. Andou, andou, atravessando a imensa noitidão. Só quando desaguou na outra margem do tempo ele ousou despersianar seus olhos. Olhou o corpo e viu que já nem a si se via.[...] Pensava que nunca mais regressaria ao seu original formato.

Nesse momento, torna-se presente a mãe de Pintalgato: "Estava-se naquele desfile de queixas e tristezas quando se aproximou uma grande gata. Era a mãe do gato desobediente". Ela não lhe oferece o ventre como local iniciático do nascimento, mas lhe oferece o olho, simbolicamente, também, Centro - da percepção de si e da própria transformação. Criador e criatura encontram-se em um momento mágico de revelação. Velho e novo descobrem-se afetivamente. $\mathrm{Na}$ interação do olhar, cria-se um entrelugar em que contracenam passado e futuro, mãe e filho, tradição e modernidade. Ali fica sintetizada uma nova identidade. E pelo caráter cíclico da obra, essa identidade está sempre em "trespassagem", em curso.

Os olhos da mãe-África guardam o destino de seus filhos. Dentro de sua pupila, Pintalgato se vê na imagem de seu novo irmão, Escuro. Duas identidades, dois modos de estar no mundo: um do passado, outro do presente - de cujo diálogo nascerá o futuro. Resgata-se, portanto, nesse jogo do olhar a questão da identidade tão cara aos escritores portugueses do pós-colonialismo.

A voz moçambicana de Mia Couto oferece-nos ao olhar uma África que se permite transgredir; faz-nos entrever a possibilidade de re-visão e de reversão de valores instituídos por toda a história colonizadora. O tempo da memória, concentrado na mãe-gata, parceiro do tempo do porvir, amalgamado nos filhos, compõem um cenário em que olhar o outro é olhar a si, é abrir os canais para fazer a própria história. Na "trespassagem" de Mia Couto, espelha-se a travessia de muitos povos africanos, iluminados por suas infinitas iniciações, suas infindáveis guerras e mazelas sociais.

Pintalgato recusa a obediência, lança-se à descoberta e à liberdade. Transitando entre o real e o imaginário, entre o sol e a lua, no espaço mágico das zonas fronteiriças, toda a transformação libertária torna-se possível. Esse é o fundamento do projeto político e estético de Mia Couto atualizado no livro $O$ gato e o Escuro. 
Mia Couto demonstra sua adesão à consciência de mundo de sua sociedade, entretanto seu compromisso é menos ideológico e mais imaginário e estético. Ele subverte o código e instaura outras relações com a lógica do discurso comum, transformando-o em fonte de fruição estética.

Assim como, no plano do conteúdo, o gato ousa atravessar a fronteira do conhecido, transgredindo o estabelecido, no plano da expressão, Mia Couto opta por 'brincriar' com a linguagem, rompendo a norma permitida. Dessa maneira, cruza as fronteiras do esperado, do previsível, do comum, para alcançar o inusitado, o imprevisível, o estético.

Atravessar para o outro lado do mundo é o convite do escritor africano para nos enredar no estranho e maravilhoso de sua arte de narrar, transgressora da lógica e emancipadora dos sonhos, marcada pelo engendramento surpreendente do sagrado.

Nesse intuito, também, Mia Couto propõe uma sagração da natureza, escolhendo como elementos de sua narrativa o animal, o sol, a lua - memória da tradição. Reinventa o olhar, trazendo à lembrança o profundo e o mágico experimentado na infância dos tempos, em que os homens tinham a consciência de estarem na natureza e, não apenas, de a visitarem. Se o livro e a escrita apresentam-se como elementos que distanciam o homem da natureza, aqui ele é veículo de reconciliação desses elementos pelas dobras do imaginário.

Por construir seu texto sob o alicerce artesanal da letra, convidando-nos a imaginar, a recriar, a fazer nossa a estória, o projeto do autor ganha outras possibilidades de leitura, especialmente se nos debruçarmos sobre os elementos simbólicos ali envolvidos.

Luz e trevas constituem dualidade universal, são correlativos inseparáveis, segundo Jean Chevalier e Allain Gheerbrant ${ }^{565}$. "[...] se a luz solar morre toda noite, também é verdade que ela renasce toda manhã, e o homem, assemelhando seu destino ao da luz, obtém dela esperança e confiança na perenidade da vida e de sua força."

Esses dois elementos compõem o processo de iniciação, que, no livro, é ficcionalmente denominado de "trespassagem". A travessia do dia para a noite remete-nos ao simbolismo da viagem, "busca da verdade, da paz, da imortalidade,

${ }^{565}$ CHEVALIER, Jean et GHEERBRANT, Allain. Op. Cit. p.569. 
da procura e da descoberta de um centro espiritual". As viagens, em geral, são perambulações dentro do próprio ser - centro de si. Elas envolvem provas, que suscitam, muitas vezes, o sentimento de medo, como revela o Escuro.

De fato, a iniciação não é um comportamento exclusivo do homem das sociedades tradicionais, ela coexiste com a natureza humana, uma vez que "toda a existência é constituída por uma série ininterrupta de provas, de mortes e de ressurreições, sejam quais forem os termos de que a linguagem moderna se serve para traduzir estas experiências originalmente religiosas" - mostra-nos Mircea Eliade ${ }^{566}$.

Os ritos de passagem, como esse que experimenta Pintalgato, desempenham papel considerável na vida do homem, implicando mudança radical de regime ontológico e de estatuto social.

Mircea Eliade ${ }^{567}$ chama a atenção para o fato de que "a existência humana chega à plenitude por uma série de ritos de passagem, em suma, por iniciações sucessivas".

O herói, como o protagonista de nossa estória, segundo Joseph Campbell ${ }^{568}$, simboliza a imagem divina, redentora e criadora que dorme dentro de cada um de nós, esperando ser transformada em vida. Ele realiza sua façanha, com o intuito de explorar o reino dos deuses - cumprindo sua missão, ocupando o cimo da estória. 0 percurso padrão de sua aventura é a magnificação da fórmula representada nos rituais de passagem: SEPARAÇÃO - INICIAÇÃO - RETORNO - três momentos que compõem a ação narrativa realizada pela personagem Pintalgato.

A viagem feita pelo leitor é espiritual, em forma de travessia, em deslocamento para o eixo do mundo-livro. O fim da travessia implica ascensão. Pintalgato sai a passeio pela "linha onde o dia faz fronteira com a noite", atravessa a luz, vence o limite, penetra no escuro disforme - "a noitidão" e deságua na outra margem do tempo-interior-imaginação, até retornar ao cimo da estória - ascensão equivalente à subida ao céu. Junto a ele, peregrina o leitor na trajetória ritual: de ser passa a não-ser até engendrar-se em novo ser. Eis a narrativa-travessia.

As simbologias da terra e da água, recorrentes nas obras do autor, aparecem nesse texto por meio de outras imagens que a elas se assemelham. A mãe-gata

\footnotetext{
${ }^{566}$ ELIADE, M. Aspectos do mito. Lisboa, Edições 70, 1989. p.167.

${ }^{567}$ ELIADE, M. Op. Cit. p. 188.

${ }^{568}$ CAMPBELL, J. O herói de mil faces. Trad. Ubirajara Sobral. São Paulo, Cultrix/Pensamento, 1997. p. 373.
} 
simbolicamente equivale-se a terra ('Tellus Mater'), por ser mãe, protetora, fonte e guardiã da história de seus filhos. A noite ou a lua guardam relação com a água, por ser o tempo das germinações, por representar as virtualidades, o indeterminado e o caos a tomar forma no dia. Há elementos verbais no texto que comprovam essa equivalência simbólica: "Só quando desaguou na outra margem do tempo, ousou despersianar os olhos. Olhou o corpo e viu que já nem a si se via. Que aconteceu? Chorou. Chorou. Chorou. Pensava que nunca mais regressaria ao seu original formato." O novo nascido da história da terra e transformado pelas águas pode ser contemplado no olho da própria-mãe, que não é só guardiã dessa estória, por ser mais velha, mas, também, é portadora dessa clarividência, por ser gata.

Motivo também recorrente nos textos do autor moçambicano, a viagem está presente nessa obra analisada na imagem da "trespassagem" e exprime o desejo profundo de transformação interna, menos vontade de deslocar-se fisicamente e mais sede de descobrir novas verdades. Viagem é signo de aventura, de procura motivada pela insatisfação, orientada para a busca de si.

Literatura é travessia, é viagem sagrada que se faz pelo sonho nas asas do Imaginário. Em sua escritura-travessia, o moçambicano Mia Couto ${ }^{569}$ revela seu segredo de escrever: "delinear a fronteira enquanto olhamos o mundo, naquele momento que nem é dia nem é noite. Podemos andar nesse novo sistema, uma expressão que eu gosto muito é o 'twilight zone', nesta zona de penumbra”.

E não é por acaso que ele escolhe a forma do conto para revelar seus momentos de epifania. Confessa, em Pensatempos: "o que interessa para o conto é o conflito interior das pessoas, o pequeno detalhe de quem se surpreende e se descobre um outro" ${ }^{570}$. O conto, também, é a forma literária que aproxima a criança, por ter sua raiz na oralidade, por engendrar elementos do maravilhoso, por ter sido e ser o primeiro conselheiro das crianças, e o primeiro da humanidade, em concordância com Walter Benjamin ${ }^{571}$.

Ao se mirar no olho da mãe, Pintalgato ganha a certeza de que seu sonho é realidade. Na pupila do olho materno, está inscrito seu passado e seu futuro. Tal como a vida de cada um de nós, ficam registradas as sucessivas "trespassagens" de

\footnotetext{
${ }^{569}$ Entrevista realizada por Sophia Beal, em Portugal, março de 2005. Disponível em: $<$ http://www.lainsignia.org/2005/marzo/cul_030.htm>. Acesso em: 08 de março de 2007.

${ }^{570}$ COUTO, Mia. Pensatempos: textos de opinião. 2. ed., Lisboa, Editorial Caminho, 2005. p. 47.

${ }^{571}$ BENJAMIN, Walter. Magia e técnica, arte e política: ensaios sobre literatura e história da cultura. Trad. Sérgio Paulo Rouanet. 7. ed., São Paulo, Brasiliense, 1994. p. 215.
} 
claro a escuro, ou seja, as infinitas iniciações. Assim também sente a criança, quando rememora seu primeiro contato com o olhar materno e intui que, naquelas páginas, desenhadas em sonho, está inscrita a trajetória de sua própria vida.

A relação da percepção-consciência, que passa pelo olhar, e está presente nos textos fantásticos, é marcante nesta narrativa moçambicana. O espelho - objeto a partir do qual Pierre Mabile ${ }^{572}$ definiu seu parentesco com 'se mirer' (mirar-se) e 'merveille', maravilha - é representado pelo olho da mãe. Nessa relação de reconhecimento de identidade, depreende-se um traço significativo da literatura africana pós-colonial, em sua missão de buscar a si e de participar da construção de novas formas de ser, de estar no mundo, de olhar o outro e de sonhar o mundo mais além.

Mia Couto alinhava literatura e sociedade, sem abandonar o aspecto lúdico que qualifica a literatura infantil no domínio do estético.

Entrar na estória de Mia Couto é suspender o ritmo ordinário e participar de uma cosmogonia, da criação de um mundo distinto da vida comum, mergulhar em um tempo cósmico, que traduz o ritmo da natureza, do dia e da noite, partilhando um tempo transfigurado pela presença de uma personagem, que, mesmo sendo um gato, realiza uma ação bem pouco comum: atravessar do dia para a noite.

Tempo indeterminado, espaço da natureza, ação ritual, presença do narrador de voz primordial, linguagem original qualitativamente distinta da prosaica, todos esses elementos costurados pelo lúdico, pelo maravilhoso, atendem ao gosto infantil e à vocação de compartilhar com o sagrado.

Em parceria com o escritor, no propósito de encantar a criança, a premiada ilustradora, Danuta Wojciechowska, admiravelmente projeta, na capa do livro, os elementos simbólicos de sustentação da obra: o gato, a lua e o sol - em uma composição inusitada que sugere, metonimicamente, o próprio olho - e a travessia. Acrescenta, em sua expressão visual, dois outros elementos: as asas nos gatos elevando-os à qualidade de seres sobrenaturais, recuperando 0 aspecto maravilhoso presente nas obras de literatura infantil - e uma janela, cuja cortina rememora as pintas dos gatos em forma de olho, em cujo centro, simulando o horizonte, é possível ver a lua, ou então uma pupila - fato que leva a criança, verdadeiramente, a "despersianar os olhos". A janela é abertura para a luz, assim

572 MABILE, Pierre apud TODOROV, Tzvetan. Introdução à literatura fantástica. São Paulo, Perspectiva, 2004. p.130. 
como o olho. Nela se debruça o leitor, para assistir ao espetáculo das formas e das cores. Livro-olho, livro-janela.

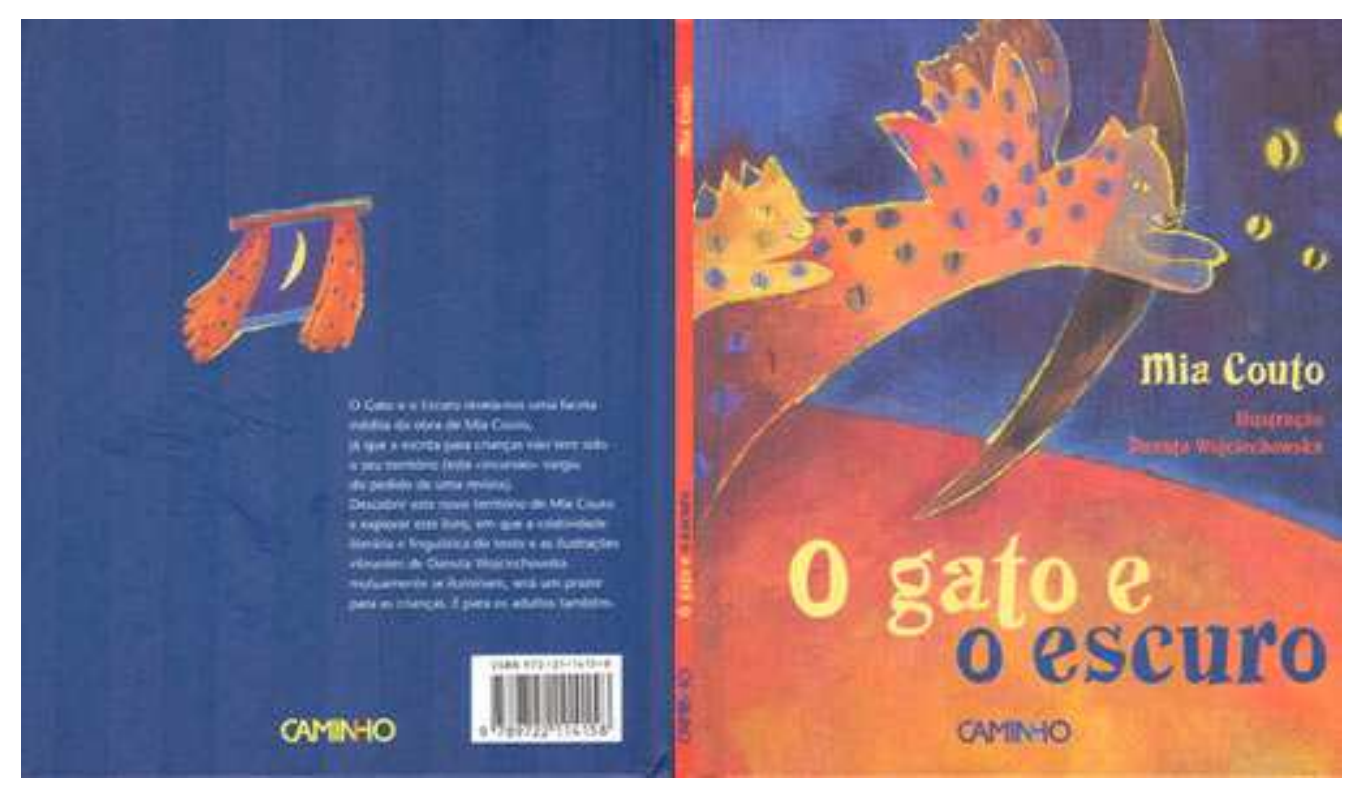

Figura 5.1

A imagem do olho é recorrente tanto na linguagem visual quanto na verbal, como se observa: "Vejam, meus filhos"; "o Pintalgato [...] espreitava o lado de lá [...]"; "seus olhos pirilampiscavam"; "olhou as patas adianteiras e se assustou"; "não queria ser visto em flagrante escuridão"; "fechou os olhos e andou assim, sobrancelhado, noite adentro"; "despersianar os olhos"; "olhou o corpo e viu que já nem a si se via"; "virara cego?"; "Olho tudo e não vejo nada"; "ele se entristecia de não enxergar os lindos olhos do bichano"; "nem os seus mesmos ele distinguia, olhos pretos em corpo negro"; "pois eu dou licença a teus olhos"; "e os olhos do escuro se amarelaram"; "quando despertou viu [...]"; "esticou as pernas e viu brilhar as unhas [...]"; "até se arrepiou vendo um irmão tão recente"; "olhe bem para os meus olhos e verá"; "Pintalgato fitou o fundo dos olhos da mãe"; "ele notou seus olhos; viu uma estranheza nunca antes reparada; quando olhava o escuro, a mãe ficava com os olhos pretos"; "abarrotar as pupilas", "ante a luz, seus olhos todos se amarelaram", "espreitou nessa fenda escura como se vislumbrasse o abismo", "0 que é que ele viu"; "viu um gato preto enroscado do outro lado do mundo".

Na penúltima página, a ilustradora nos apresenta um olho enorme e vazado, de cor amarela, estilizando o sol-dia, dentro do qual repousa a pupila-noite, sinalizando as fronteiras simbólicas de travessia e construção de identidades. Dentro da pupila, habita o gato escuro, o mesmo que pousa como guardião no cimo do livro, 
nas páginas iniciais. Assim, por meio da ilustração, evidencia-se o caráter cíclico da narrativa, que the confere a possibilidade de movência, reafirmado pelas páginas duplas ilustradas pelas pintas amarelas sugerindo, metonimicamente, a personagem protagonista Pintalgato.

Ao folhearmos as páginas, atentos às ilustrações, vivenciamos um movimento permanente de travessia. A própria página do livro serve de fronteira.

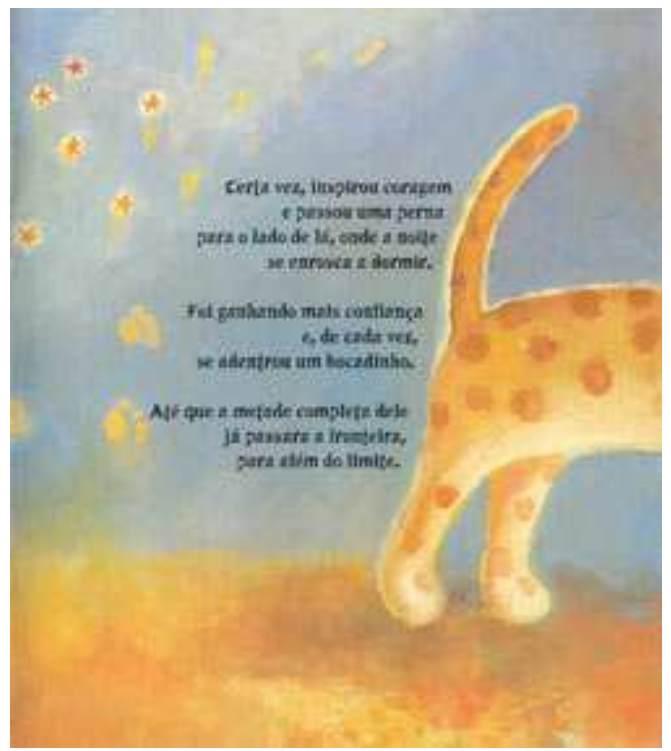

Figura 5.2

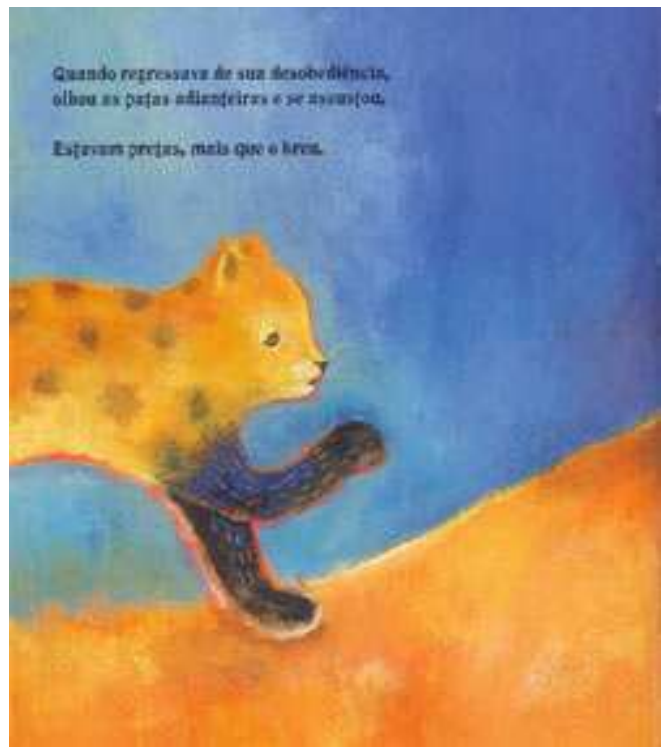

Figura 5.3

A forma dinâmica como articula as figuras, com traços circulares e em perspectiva, faz rememorar, no plano imagético, o movimento de uma narrativa contada em 'performance'.

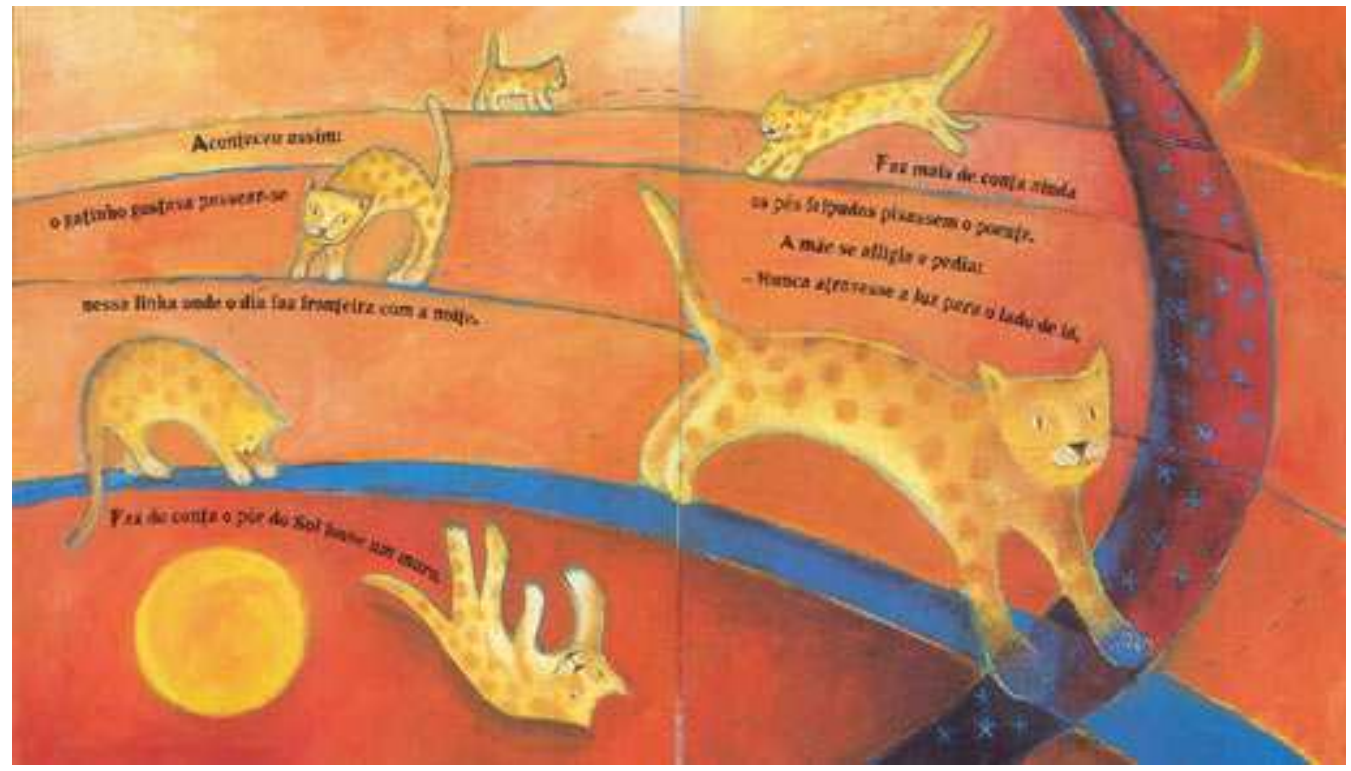

Figura 5.4 
Tanto o escritor quanto a ilustradora, em suas diferentes linguagens, acordam nossos órgãos do sentir, convidando-nos ao espetáculo do ouvir e do olhar. Ambos nos abrem as janelas para os territórios de nossa própria identidade.

Olhar é adentrar o mundo, vendo-o dentro de si. A visão expõe o interior ao exterior. Como janelas da alma, os olhos são o espelho do mundo. Escutar é trazer o outro para dentro de si e gerar um pensar compartilhado e sensível a ele. Entrecruzam-se, nas duas linguagens, atos solitários e solidários, ambos importantes para o desenvolvimento humano.

Visão e audição, entrelaçadas com a imaginação instauram uma nova maneira de conhecer a si, ao outro e ao mundo.

É sustentável afirmar que a ilustração não tem, nesta obra, função de ornar ou simplesmente elucidar o texto junto ao qual ela aparece. Seguindo as caracterizações de Luis Camargo ${ }^{573}$, ela assume, aqui, várias outras funções: ora imita a aparência do ser ao qual se refere, traduzindo uma função representativa; ora descreve cenas, com função descritiva, ora narra passagens da estória, revelando função narrativa; há a função expressiva, a lúdica, principalmente nas páginas de abertura e fechamento do livro, a função metalingüística é visível no início e na passagem do limite entre o dia e noite, entretanto predomina a função estética, enfatizando a forma da mensagem visual. Predominam os significados conotativos da imagem, sugerindo associações inusitadas, metonímias, metáforas, figuras de linguagem que alimentam a retórica visual, ora sugerindo sentidos, ora reinventandoos.

A metonímia é figura recorrente nas páginas que abrem e fecham o livro, nas quais malhas e pintas amarelas sugerem a personagem central, Pintalgato; outras há quando o gato atravessa a fronteira do dia e da noite, nas imagens de pequenos olhos "pirilampiscando" no escuro da noite.

A metáfora apresenta-se na imagem do gato chorando por ter encontrado 0 escuro, na imagem do corpo assemelhado ao arco-íris, na cena de travessia, em que Pintalgato ganha asas e, na cena seguinte, em que está ultrapassando a fronteira.

${ }^{573}$ CAMARGO, Luís. Ilustração do Livro Infantil. Belo Horizonte, MG, Editora Lê, 1995. 
A personificação, atribuição de características humanas a seres de outros reinos, é evidente na imagem do gato que realiza o feito extraordinário de cruzar a fronteira do dia e da noite, em busca de sua identidade. Ele se surpreende com a pata escura. Também o escuro é personificado, ganhando forma de gatopersonagem, de ser vivo.

A hipérbole é recorrente nas imagens reveladoras da mãe, de forma a valorizá-la.

A leitura linear é quebrada, em alguns momentos, especialmente no da travessia, tanto do dia para a noite, quanto do exterior para o interior, em que o texto verbal passa a compor diálogo com o corpo do gato e da mãe.

Percebe-se a criação estética nas formas e nas cores com que o gato revela suas identidades. Ora se mostra com asas, com pintas e malhas, ora apresenta-se azul, vermelho, só contorno, ou apenas sombra. São cores e formas nãoreferenciais, estilizadas. As formas arredondadas dos desenhos à mão livre conferem movimento, afetividade e coerência com a proposta cíclica.

As cores, com seus diferentes matizes, sugerem o dia, predominantemente amarelo - e a noite - predominantemente azul. Essa associação é coerente com as cores do gato, antes amarelo, com malhas e com pintas - em harmonia com o dia e, depois, preto, em consonância com a noite, a escuridão interior, o caos, as trevas, que precedem a descoberta. A seleção cromática resgata a simbologia solar e lunar que predomina na obra e converge para a simbologia da iniciação: a "trespassagem de claro para escuro".

O azul e o preto são cores frias, evocando introspecção, profundidade, imaginação. O preto - a totalidade negra - é a ausência total de cor. Simboliza o caos, do silêncio, do invisível, das trevas anteriores a uma nova ordem.

O amarelo é do dia, da luz, do sol, da razão, do visível. Segundo Jean Chevalier e Allain Gheerbrant, é a mais quente, a mais expansiva e a mais ardente das cores, sempre ultrapassando os limites em que o artista pretendia encerrá-la. É a cor dos deuses. É a cor oposta e complementar ao negro. O amarelo separa-se do negro no momento da diferenciação do caos em relação à indiferenciação primordial.

Logo na primeira cena do livro, em que ocorre a apresentação da personagem principal em conjunção de identidades: passado e presente, o narrador revela o grande tema simbólico e sagrado da narrativa: a "trespassagem" do claro para o escuro. Nas cores do gato, inscreve-se sua própria história. No espetáculo 
das formas e das cores, no maravilhoso espectro das trevas à luz, da morte à vida, revela-se a linguagem sagrada da existência.

Psicólogos e analistas associam a ascensão com as imagens luminosas e com o sentimento de euforia, e a descida é relacionada com as imagens sombrias acompanhadas do medo. A luz associa-se à subida, à forma, enquanto a escuridão liga-se à descida, ao amorfo. Essas imagens e movimentos simbólicos estão muito bem trabalhados no plano da ilustração do livro.

A predominância de formas simplificadas e de cores primárias, sem preocupação em guardar referencialidade com o representado lembra o fauvismo ${ }^{574}$ e reforça o laço com as pinturas infantis, com o primitivo, com o inaugural. Ao mesmo tempo, seduzem o olhar do leitor-criança, que penetra, curiosamente, nas dobras da linguagem visual, admirando-se e alimentando-se com a simplicidade e com a essência de suas formas e cores.

Se entendermos, conforme nos ensina Luis Camargo, a ilustração como uma segunda linguagem que acompanha um texto, e não seu substituto; e se admitirmos que a relação entre ilustração e texto não é a da paráfrase ou a da tradução, mas a de coerência, logo, concluiremos que a ilustração de Danuta Wojciechowska mostrase convergente ao texto verbal na apresentação da função estética.

Tanto o texto visual quanto o verbal deixam marcas que abrem para o leitor o sentido original de invenção, ou o de reinventar-se. Como linguagens distintas, metaforizam-se em janelas para o homem e para o mundo.

Se "a janela é onde a casa vira mundo", o olho é onde o homem vira sonho. É esse o convite que nos faz a ilustradora, de mãos dadas com as do escritor, ao colocar, diante de nossos olhos, o teatro do mundo. Na travessia que nos faz reconhecer o invisível no visível, o extraordinário no ordinário, o sagrado no profano, entrevemos a espessura de nossa própria existência.

\footnotetext{
${ }^{574}$ Movimento especialmente francês, cujas características marcantes são a simplificação das formas, o estudo do uso das cores, e a redução do nível de graduação das cores utilizadas nas obras. A cor passou a ser usada para delimitar planos, criar perspectiva e modelar volume. Rompeu com o vínculo da referencialidade das cores e do objeto representado - o que conferiu expressividade às obras.
} 


\section{CAPÍTULO 6}

\section{O SAGRADO EM MANOEL DE BARROS E MIA COUTO}

"um homem não é uma margem que apenas existe de um ou outro lado. Um homem é uma ponte ligando as diversas margens."

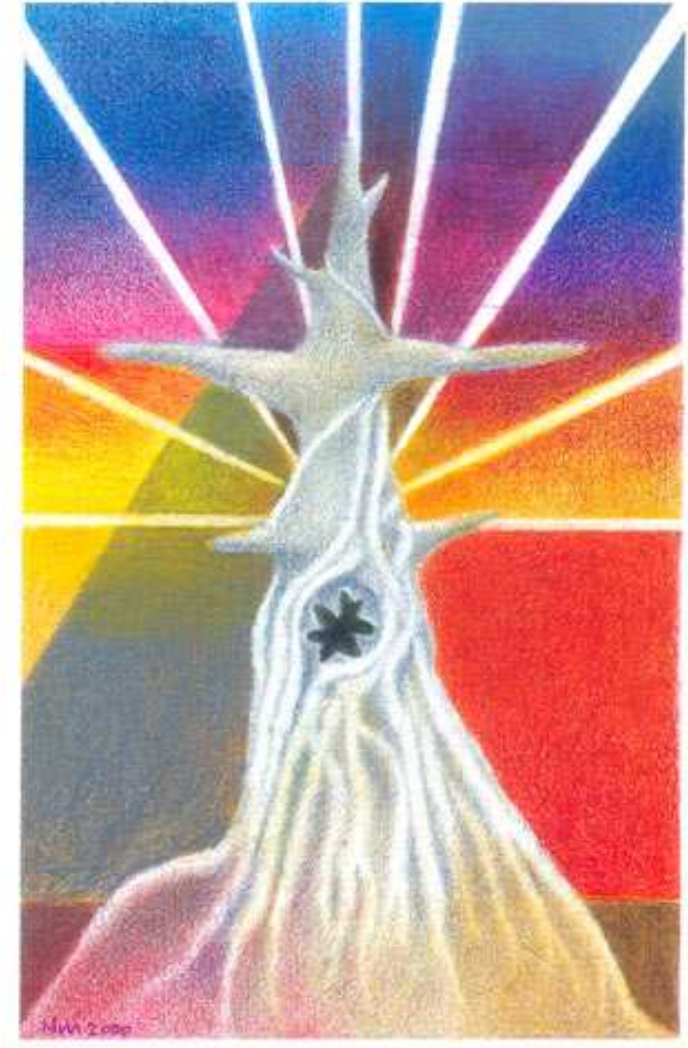

Ilustração 7 - arte de João Nasi Pereira para Mar me quer, de Mia Couto (2000)
(Mia Couto) 


\subsection{De Inícios e Fronteiras}

Neste capítulo, nosso objetivo é fazer uma análise comparativa entre os projetos políticos e estéticos de Manoel de Barros e de Mia Couto, a fim de mostrar a forte presença do sagrado como elemento estruturador.

Em seu plano, Manoel de Barros desenha um homem de inícios. Mia Couto esboça um homem de fronteira. Aquele vislumbra um lugar-primeiro; este, um entrelugar. O brasileiro arquiteta esse novo homem afirmado nas origens, pela recusa da modernidade e do paradigma vigente. O africano conjuga o novo homem nas fronteiras, buscando costurar a tradição na modernidade.

Esses projetos políticos e estéticos guardam vínculo com o contexto histórico de cada nação. A voz de Mia Couto ressoa as aspirações de uma sociedade recémindependente, em busca de sua própria identidade e em processo de modernização. Por isso, sua letra prende-se bastante a terra, na denúncia de suas mazelas, ampliando-se ao universal e se firma como voz que transita fronteiras. Já a voz de Manoel de Barros ecoa os desejos de uma sociedade que vem experimentando a modernidade há algum tempo, tendo vivenciado sua maior crise de identidade no mínimo há dois séculos, portanto pode desconfiar e recusar.

Como recusa à modernidade erguida sobre as bases de um capitalismo selvagem e perverso, Manuel de Barros define a matéria de sua poesia como tudo que é descartado do sistema: o silêncio, o vazio, a natureza, a infância, a velhice, o lixo, o ínfimo, a própria poesia, entre outros. Objetos portadores de valor de uso e de troca para o sistema perdem suas referências para ganharem outras, como a máquina - elemento representativo do sistema capitalista - que vira lixo e passa a milagrar flores. Assim, devolvendo às coisas seus inícios, vai ressacralizando o que se dessacralizou com as leis do consumo e com a lógica racional - sustentáculo da modernidade.

Mia Couto $^{575}$, na busca de reconhecer as identidades que compõem sua nação e a condição humana, afirma seu olhar de fronteira:

Não há nenhum de nós que seja cidadão de uma só nação. Repartimo-nos por universos vários. Somos cidadãos da oralidade e da escrita. Somos urbanos e rurais. Somos da nação da tradição e da modernidade. Sentamo-nos ao computador e na esteira, sem nos

${ }^{575}$ COUTO, Mia. Pensatempos: textos de opinião. 2.ed., Lisboa, Editorial Caminho, 2005. p. 93. 
sentirmos estranhos em nenhum dos assentos. E é assim que terá que ser: partilhamos mundos diversos sem que nenhum desses universos conquiste hegemonia sobre os outros.

Em Manoel de Barros, as estruturas de dominação e de opressão provêm do mundo moderno, das máquinas, do capital, das engrenagens globalizadas e do pensamento que as engendrou. Por isso, ele se opõe à lógica logocêntrica, que preside tal ordem das coisas e aposta na origem, no retorno a um substrato anterior à civilização, à razão. Mia Couto, também, posiciona-se avesso à lógica centrada na razão, mas sua desconfiança advém da violência imposta pelo sistema colonizador. Se analisarmos os silêncios de que ambos falam, perceberemos que Manoel de Barros pretende resgatar o silêncio anterior à palavra, ao nome, buscando o lugar primeiro anterior à civilização e à linguagem. Já Mia Couto dialoga com o silêncio que oprime, que inibe a transformação do homem como sujeito da sua história.

Portanto, ambos recusam a lógica fundadora do 'ethos' moderno. É na filosofia de Descartes e Bacon que ela se apóia. O "penso logo existo" condiciona a existência ao pensar. Como o homem é o ser dos seres capaz de pensar, ele se atribui o poder de subjugar a natureza. Assim, o saber se volta para a dominação (saber é poder) e controle dessa natureza, servindo esse tipo de racionalidade à ideologia do progresso.

Ambos os autores mostram discordância desse 'logos' absoluto, que presidiu todo o processo colonizador ocidental aos continentes periféricos, como a América Latina e a África. Por isso, buscam libertar os leitores dos círculos redutores dessa racionalidade dominante.

Propõem uma racionalidade outra. Manoel de Barros nega o pensar abstrato, adulto e conceitual, enaltecendo a ignorância - que, para ele, não tem sentido pejorativo, traduzida como "ignorãça" -, valorizando o pensamento mágico, concreto, infantil e primitivo. Mais do que pensar, tanto Manoel de Barros quanto Mia Couto convidam-nos a sentir, as canções do de ver e as pinturas do ouvir. Mais do que conceitos abstratos, encontramos, em suas obras, experiências vividas.

Ambos operam com uma linguagem grávida de analogias e de figuras, de metáforas, de metonímias, que recuperam o valor afetivo das palavras. Fazem ressoar, em seus textos, a música dos sentidos, ligada ao corpo, em especial à visão e à audição. O encadeamento lógico entre causa e efeito não é preocupação para 
os autores, que se valem da lei da participação, segundo a qual todas as coisas estão entrelaçadas, entre elas o natural e o sobrenatural, o profano e o sagrado.

Cumpre destacarmos que Manoel de Barros reinventa, Mia Couto registra. A cultura brasileira apresenta características distintas da cultura moçambicana.

Em Moçambique e, em geral, nas culturas africanas, o sagrado participa do profano. O homem moçambicano está ligado ao cosmos, podendo ser considerado um 'homo religiosus', no entender de Mircea Eliade, pois não perdeu a ligação com o sagrado. No universo visível, são percebidos sinais do invisível, o comportamento humano é regulado por rituais. Violar as leis sagradas é prejudicial e desequilibra as forças do grupo. Assim, nessas sociedades, material e espiritual não estão dissociados. Mia Couto traduz o saber ancestral que compõe, culturalmente, Moçambique. Pela ancestralidade, os homens vivos religam-se aos espíritos de seus antepassados, os quais continuam a emitir sinais, mesmo mortos. Dessa maneira, o mundo visível dos vivos comunica-se com o mundo invisível dos mortos. Isso confere ao homem uma outra noção de tempo, diferente da ocidental. Mia Couto deixa registro preciso e claro dessa comunicação. Esses elementos advindos de cosmovisões das culturas autóctones preservaram-se, pois os colonizadores não tiveram presença tão forte, eliminadora dos referenciais primeiros.

No Brasil, por sermos tributários de uma colonização que destruiu as culturas autóctones, esses laços do sagrado com o profano não são visíveis, mas podem ser reconhecidos, apesar de apresentarem-se de maneira camuflada.

Por abraçarem uma linguagem que manifesta o pensar mágico, os escritores incursionam pelos terrenos do onírico. Assim, desafiam o leitor a considerar a incerteza, o inesperado, o imprevisível, o extraordinário, visto que operam com o fantástico, com o maravilhoso e com o surreal.

Dessa forma, criam um mundo mágico e pleno de significados, no qual a hesitação se instala, fazendo o leitor refletir sobre a situação real metaforizada pelo texto ou com ela encantar-se.

A marca do fantástico, do maravilhoso e do surreal, como estratégia literária da inconformação, traduz o esgotamento da racionalidade hegemônica, o desconcerto do sentido da existência. Desconcerto esse, provocado, em Moçambique, pelas sucessivas guerras; no Brasil, pelos fenômenos da mercantilização do mundo e das relações, pela globalização e pela reificação do homem. Como forma de reinvenção estética e existencial, essa expressão literária 
do estranhamento posiciona a linguagem como indagação. Assim, o cotidiano é permanentemente reinventado, abrindo canais para o homem ser ou imaginar-se diferente, em busca de encontrar um outro destino.

Ambos os autores fazem questão de operar com a lógica da oralidade. Assim, a escrita é deslocada de seu centro hegemônico. A espontaneidade da expressão, a inventividade nos neologismos, a possibilidade de subverter, de transgredir, de recriar, rompendo, afetivamente, com a norma gramatical estabelecida, o uso de repetições, de onomatopéias - enfim, o emprego de recursos da oralidade acaba por imprimir ao texto sonoridade e visualidade, despertando, no leitor, uma apreensão corpórea.

Tanto para Manoel de Barros quanto para Mia Couto, a oralidade coaduna-se com a infância. Revela o moçambicano: "Essa oralidade é uma espécie de pátria onde vivemos a infância e da qual não fomos nunca completamente expulsos. Não são apenas os camponeses analfabetos que sustentam esse universo. Nós todos já vivemos na oralidade" ${ }^{576}$. Em consonância, o brasileiro:

\footnotetext{
Por viver muitos anos dentro do mato moda ave

O menino pegou um olhar de pássaro Contraiu visão fontana.

Por forma que ele enxergava coisas

por igual

como os pássaros enxergam.

As coisas todas inominadas.

Água não era ainda a palavra água.

Pedra não era ainda a palavra pedra.

E tal.

As palavras eram livres de gramáticas e

Podiam ficar em qualquer posição.

Por forma que o menino podia inaugurar.

Podia dar às pedras costumes de flor.

Podia dar ao canto formato de sol.

E, se quisesse caber em uma agulha, era

Só abrir a palavra abelha e entrar dentro

dela.

Como se fosse infância da língua. ${ }^{577}$
}

\footnotetext{
${ }^{576}$ COUTO, Mia. In: Revista Via Atlântica. n 8. São Paulo, Departamento de Letras Clássicas e Vernáculas, Faculdade de Filosofia, Letras e Ciências Humanas, Universidade de São Paulo, 2005. p.213.

${ }^{577}$ BARROS, Manoel. Poemas Rupestres. Rio de Janeiro, Record, 2007. p.11.
} 
Concebendo a língua como matéria-prima com a qual se pode sonhar, brincar, verter, reverter, enquanto um faz brincriações ${ }^{578}$, o outro faz peraltagens ${ }^{579}$. Ambos, pelas artimanhas do lúdico, fazendo da língua um eterno vir-a-ser, encantam o leitor, lançando-o na dimensão do sagrado. Jogo de palavras, jogo de sentidos, jogo nos planos fonético, morfológico, sintático e semântico envolvem o leitor em um espaço imaginário, em um tempo qualitativamente distinto do cotidiano, portanto, para Mircea Eliade, sagrado.

Para Johan Huizinga ${ }^{580}$ : "em sua função original de fator das culturas primitivas, a poesia nasceu durante o jogo e enquanto jogo - jogo sagrado, sem dúvida, mas sempre, mesmo em seu caráter sacro, nos limites da extravagância, da alegria e do divertimento". E acrescenta o autor que "a 'poiesis' é uma função lúdica" ${ }^{581}$, uma vez exercida na região lúdica do espírito, diferente da que se mostra na vida comum. Para ele, poesia está em um plano mais primitivo e originário ao qual pertencem a criança, o animal, o selvagem e o visionário, "na região do sonho, do encantamento, do êxtase e do riso."

Acredita Mia Couto ${ }^{582}$ que o dever do escritor é para com a língua, necessitando reinventá-la, "salvando-a dos processos de banalização que o uso comum vai estabelecendo", impregnando-a do mítico e da oralidade. Confessa o autor que aprendeu com o brasileiro Guimarães Rosa, ao ser presenteado com a poesia de linguagem sagrada, capaz de deixá-lo em "estado de transe", assim como um dançarino que prepara a possessão pelos espíritos. Com as leituras do brasileiro, aprendeu a ouvir as vozes dos contadores de sua infância e a criar um momento divino, mergulhando na oralidade, escapando da racionalidade como sistema único de pensamento. Ao converter a língua em uma espécie de Caos inicial, Guimarães torna-se fundador de um reinício. E Mia Couto ${ }^{583}$ tem-no como mestre, tal como assume: um "ensinador de ignorâncias de que tanto carecemos para entender um mundo que só é legível na margem dos códigos da escrita".

\footnotetext{
578 Mia Couto faz essa sugestão em Contos do nascer da terra: "Mas Sombrinha não deixou de rimar com a alegria. Afinal, era ainda menos que adolescente, dada somente a brincriações."(COUTO, Mia. Contos do nascer da terra. 6.ed., Lisboa, Editorial Caminho, 2006. p. 14)

579 Manoel de Barros alia essa expressão à tarefa do poeta.(BARROS, Manoel. Exercícios de ser criança. Rio de Janeiro, Salamandra, 1999).

${ }^{580}$ HUIZINGA, Johan. Homo Ludens. São Paulo, Perspectiva, 1996. p.136.

${ }^{581}$ Idem, ibidem. p.133.

${ }^{582}$ COUTO, Mia. Pensatempos: textos de opinião. 2.ed., Lisboa, Editorial Caminho, 2005. p.111.

${ }^{583}$ Idem , ibidem. p. 108.
} 
O africano e o brasileiro guardam semelhanças não só na forma como concebem a língua, mas, também, na tarefa de fazer ouvir a magia da voz na artesania da letra.

Nos dois contextos, a tradição oral cumpre seu papel como elemento autóctone, porque, nas duas culturas, a escrita foi introduzida pelo processo de colonização.

Ambos os autores recuperam a voz do narrador tradicional - o contador de estória ou o 'griot' - memória viva da comunidade, assim fazem avivar, na matéria narrada, o pensamento arcaico-popular do homem religioso, na tentativa de recuperar o tom encantatório do discurso oral, antes de ser cristalizado pela escrita.

A voz não só ressoa na letra, mas a fecunda, entretecendo a memória do velho na esperança do novo. Quando se pretende construir um futuro transformado, deve-se valer de imagens recuperadoras do mundo antigo, como afirma Laura Cavalcanti Padilha ${ }^{584}$. Os antigos ecos da oralidade ressoam na letra literária, na tentativa de retecer a experiência da vida nas malhas da ficção.

A narração que se funda no faz-de-conta e evidencia a tradição oral, por ser lúdica, tem valência sagrada. É o que mostra Johan Huizinga ${ }^{585}$ : "em nossa concepção de jogo, desaparece a distinção entre a crença e o faz-de-conta". "A noção de jogo associa-se naturalmente à de sagrado". Acrescenta o autor para explicar a tradição: "mesmo depois de o jogo ter chegado ao fim, ele permanece como uma criação nova do espírito, um tesouro a ser conservado pela memória. É transmitido, torna-se tradição" 586 .

No esforço de reanimar o passado, Manoel de Barros e Mia Couto resgatam as formas primeiras da tradição oral ${ }^{587}$ : mitos, lendas, provérbios, adivinhas, contos - intertextualizando-as, em uma gramática inventiva e estética.

A convocação da voz na partilha do espetáculo em letra, para Mia Couto, põe às claras a tensão entre tradição e modernidade na busca da moçambicanidade. $O$ patrimônio cultural perdura tanto por meio da oralidade quanto por meio da escrita, pelo fio infinito da memória. É o que afirma o escritor africano, em entrevista à Revista Via Atlântica:

\footnotetext{
${ }^{584}$ PADILHA, Laura Cavalcanti. Entre voz e letra: o lugar da ancestralidade na ficção angolana do século XX. Rio de Janeiro, EDUFF, 1995. p.153.

${ }^{585}$ HUIZINGA, Johan. Homo Ludens. São Paulo, Perspectiva, 1996. p.30.

${ }^{586}$ Idem, ibidem. p.13.

${ }^{587}$ Conforme já enunciamos, as formas simples de Andre Jolles.
} 
A tentação mais forte e mais imediata hoje em Moçambique é a de erguer aquilo que se apresenta como tradição para dar credibilidade a uma certa identidade. Quanto mais perto dessa tradição e de uma certa oralidade mais próximos estaríamos dessa tal moçambicanidade. Mas isso é uma idéia simplista contra a qual vou lutando. É preciso fazer um bocadinho o caminho com duas pernas: tem que ter um pé na tradição e outro pé na modernidade. Só assim se chega a um retrato capaz de respeitar as dinâmicas e as relações complexas do corpo moçambicano. ${ }^{588}$

Em Manoel de Barros, o ressoar da voz pelas fissuras da letra é saída viável para realizar a trajetória em espiral, rumo ao início, e ascender à criança.

A forma como ambos usam a oralidade em suas obras aproxima-os da linguagem do próprio chão. Mia Couto afirma uma África originária. Conjuga até mesmo termos das culturas locais. Contudo, faz questão de destacar que a visão que se tem do passado é de uma África pré-colonial como um universo intemporal, isento de conflitos e contradições, um verdadeiro paraíso - como veiculado no discurso colonial. Essa visão romântica retira de seus habitantes a responsabilidade de transformação, pois imagina que o ruim foi sempre feito pelo outro e não por si. Definições apressadas de africanidade constituem-se na base do exotismo, "como se os africanos fossem particularmente diferentes dos outros, ou como se as suas diferenças fossem o resultado de um dado de essência"

Manoel de Barros, também, ao ocupar a escrita pela fala, mostra um Brasilmenino, por meio de um universo simbólico que se projeta em uma terra sagrada chamada infância, que procura resgatar continuamente, pois seu projeto é fazer nascimentos, empoemar a vida, inaugurar o mundo.

Em Moçambique, o português é língua recém-nascida, por isso precisa ser redescoberta. No Brasil, a língua pode comemorar um século de vida festiva, desde a Semana da Arte Moderna, mas Manoel de Barros faz questão de preservar esse jogo inaugural das formas que engravidam o homem.

Ambos recuperam, na artesania da letra, a magia voz. O brasileiro busca a voz primeira, o moçambicano, a voz da tradição, ambos fazem ouvir origens.

\footnotetext{
${ }^{588}$ REVISTA VIA ATLÂNTICA. n 8. São Paulo, Departamento de Letras Clássicas e Vernáculas, Faculdade de Filosofia, Letras e Ciências Humanas, Universidade de São Paulo, 2005. p.207.

${ }^{589}$ COUTO, Mia. Pensatempos: textos de opinião. 2.ed., Lisboa, Editorial Caminho, 2005. p.19.
} 
Apesar de hibridizarem gêneros, transitando entre a prosa e a poesia, rompendo com fronteiras tradicionalmente estabelecidas, cada um elege, predominantemente, um gênero ou uma forma para afirmar seu projeto estético.

Ao elegerem a poesia e o conto, respectivamente, como gênero e forma de seus planos estéticos, Manoel de Barros e Mia Couto assemelham-se na tarefa de mostrar uma iluminação súbita da vida, um fragmento capturado em flagrante, focalizando o ser. Entretanto, distanciam-se na forma literária que fazem fundar suas cosmovisões.

Manoel de Barros busca resgatar o que se perdeu com a modernidade. Diante do mundo da informação, o escritor brasileiro reivindica e busca instaurar a potência mágica da palavra criadora. Busca a originalidade na experiência primitiva. Portanto, sua poesia apresenta-se menos como a expressão subjetiva de um estado anímico e mais como um processo de fundação de mundo, de linguagem, de nominação. Volta à raiz dos fenômenos e das manifestações, da expressão, buscando o ritmo primeiro, o momento inaugural em que o mundo se fazia som e imagem ao homem. Retorna ao nascimento da linguagem, momento em que a palavra se ocupava da imagem no esforço de traduzir a natureza. Volta ao tempo de nomear as coisas, o momento mitopoético da humanidade. Daí a coerência de ele operar, predominantemente, com a poesia em seu projeto estético de retorno às origens. Essa experiência originária, essa fala inauguradora do mundo teve, na palavra, a manifestação do sagrado. É sustentável afirmar, portanto, que o projeto estético e político de Manoel de Barros funda-se no sagrado.

Mia Couto também busca resgatar as origens, entretanto seu retorno é a tradição oral, a 'performance', por isso seu projeto estético mostra-se coerente na eleição do conto como forma do gênero narrativo. Se para Paul Zumthor ${ }^{590}$, a 'performance' é jogo e, para Johan Huizinga ${ }^{591}$, reconhecer o jogo é reconhecer o espírito, é lícito afirmar que o projeto estético e político de Mia Couto apóia-se no sagrado. Em síntese: ambos os projetos afirmam-se na dimensão sagrada: o de Manoel de Barros nas fontes primeiras da linguagem, nos silêncios anteriores à cultura e à civilização; o de Mia Couto nos movimentos de alma, de olho e de mão apoiados pela voz em comunicação da experiência vivida.

\footnotetext{
${ }^{590}$ ZUMTHOR, Paul. A letra e a voz: a "literatura" medieval. Trad. Amálio Pinheiro e Jerusa Pires Ferreira. São Paulo, Companhia das Letras, 1993. p.240.

${ }^{591}$ HUIZINGA, Johan. Op. Cit. p. 6.
} 
Tanto Mia Couto quanto Manoel de Barros lutam com as armas da palavra literária por uma causa que Ihes soa digna. Deixam em festa a palavra marginal para pôr em cena outras vozes, outras falas: daqueles que não se submetem ao sistema, portanto perambulam, erram, são mais velhos que jovens, pensam mais como crianças do que como adultos, são mais mulheres do que homens, e seus laços se fazem com a terra, as plantas, os animais, os minerais - enfim, com a natureza. Trata-se de seres que, ou se colocam fora do sistema, ou o subvertem por dentro. Mesmo não tendo o domínio da marca hegemônica da letra, essas gentes revelam seu conhecimento de forma sábia, ou mesmo anunciam um novo conhecimento. Tanto Mia Couto quanto Manoel de Barros colocam, no centro de seus discursos, os que vivem na periferia dessa lógica e dessa racionalidade dominante, nas bordas do sistema que eles se recusam a acatar. São, em geral, homens simples, muitas vezes do mundo rural, pouco nobres, pouco célebres e muito próximos da natureza e do sagrado.

São entes sem nome, ou de nomes esquecidos pelas fontes hegemônicas, mas, inevitavelmente, seres de origem, de raiz, especialmente humanas que desfilam suas identidades e abrem-se ao diálogo. Em geral, apresentam nomes motivados, ora por suas características, ora pelas estórias que contam, ou seja, suas identidades são marcadas por uma história vivida ou sonhada.

O avô é figura bastante valorizada tanto em Manoel de Barros quanto em Mia Couto. Em Manoel de Barros, porque é homem abandonado, marginal, descartado do sistema, mas reconciliado com a natureza; em Mia Couto, por ser guardião da memória e da tradição. Em ambos, esse avô recupera o avô poético, o narrador primeiro.

Em Manoel de Barros, o avô ensina a desler, a destecer a aprendizagem, a desaprender a história humana até chegar ao estado coisal e essencial ${ }^{592}$, o inominado para, a partir daí, passar a nominar, a inaugurar, portanto o projeto estético e político desse autor pressupõe o movimento escatológico para, a partir dele, operar uma nova cosmogonia. Por isso, em Manoel de Barros, a figura da criança também tem muita força, visto que sua proposta é de criação de um mundo

\footnotetext{
${ }^{592}$ Vale ressaltar que esse movimento de desfazer mostra-se visível em sua obra, inclusive pela recorrência do prefixo des: em desaprender, desexplicar, desinventar, desacontecimentos, despalavra, deslimites, entre outros.
} 
outro, de um olhar inaugural sobre a vida, de um novo exercício de fazer nascimentos.

O velho de Mia Couto não deslê, mas guarda e ensina a tradição, e o faz com o novo, portanto o velho precisa ser preservado como forma de garantir o passado, e o novo, como maneira de perpetuar e, ao mesmo tempo, transformar suas identidades em curso, visto que seu projeto é costurar a tradição na modernidade, reconhecendo a diversidade e as mestiçagens. $O$ autor africano coloca em cena esse mosaico de diferenças, aposta nessas identidades múltiplas e plurais, porque entende que este é seu patrimônio. Mia Couto ${ }^{593}$ não acredita em "virgindade ética e racial". Duvida da contradição entre tradicional como puro e o moderno como impuro, porque afirma uma África com pleno direito à modernidade, com plenas possibilidades de assumir suas mestiçagens, inclusive é isso que, para ele, torna-a mais rica.

Tanto o brasileiro quanto o moçambicano envergam a matéria literária para o chão, naquilo que ele traz de natureza: animais, vegetais, minerais, humanos.

O espaço, o território, as paisagens predominantes em seus textos correspondem ao mundo natural, em especial ao meio rural.

Entre tantos seres que habitam esse mundo sacralizado, tanto Manoel de Barros quanto Mia Couto guardam profunda admiração pela árvore. Para ambos, ela configura-se como uma hierofania vegetal. Para o primeiro, de maneira camuflada; para o segundo, de forma desnudada.

Em Manoel de Barros, esse elemento natural evoca o máximo da sabedoria sintetiza todos os elementos da natureza: terra em suas raízes; água em sua seiva; ar em suas folhas e fogo em seus galhos. Para esse autor, ela é um modo de estar no mundo ("estar árvore"), pleno de iluminação, integrado à matriz universal e cósmica, estado de fonte, de plenitude. Associa a árvore a uma personagem: Bernardo, projetando, nessa síntese, um novo homem e uma nova forma de estar no mundo, ou de conhecer. Bernardo-árvore é o que tem o dom de poeta, sabe ouvir as vozes da origem, do chão, ascende à criança. Com esse desenho estético, Manoel de Barros sonha um novo homem, conjugado com o cosmos e com a natureza, comungado, portanto, com o sagrado. Bernardo é um fundador de mundo e se sustenta à margem da civilização, compondo-se com o tempo primordial. Tem

${ }^{593}$ COUTO, Mia. Pensatempos: textos de opinião. 2.ed., Lisboa, Editorial Caminho, 2005. p.60. 
atributo de bocó - cumpre relembrar que o nome não possui tom pejorativo -, "alguém acrescentado de criança". Assemelha-se a andarilho, sem nome nem relógio, sem programação. O esmo o erra, porque está aderido à natureza e à inocência. "É ser que não conhece ter".

Em Mia Couto, a árvore tem alma eterna e guarda íntima e sagrada relação com os homens. São "sentinelas da terra", "testemunhos da Antigüidade" "594, uma espécie de altar $^{595}$. Em Varanda do Frangipani, confirma-se: "A gente toca o tronco e sente o sangue da terra circulando em nossas íntimas veias." 596 "A árvore era o lugar de milagre. Então, desci do meu corpo, toquei a cinza e ela se converteu em pétala. Remexi a réstia do tronco e a seiva refluiu, como sêmen da terra. A cada gesto meu o frangipani renascia. E quando a árvore toda se reconstituiu natalícia, me cobri com a mesma cinza em que a planta se desintactara. Me habilitava assim a vegetal, arborizado. [...]. Na luminosa varanda deixo meu último sonho, a árvore do frangipani“. ${ }^{597}$ Em Contos do nascer da terra, o velho Canhoto transforma-se em palmeira: "A ave toda noite debicou o pescoço de Canhoto. Dizem que, desse mesmo pescoço, ascendeu a matéria do colmo, dos cabelos brotou a folhagem, dos olhos nasceu a florescência. Tudo em jeito de árvore, palmeira e sagrada." ${ }^{598} \mathrm{Em}$ Vozes Abensonhadas, no conto "Afinal Carlota Gentina", a personagem quer aprender a ser árvore - símbolo que se abre ao céu, preso ao chão.

Em Mia Couto, visivelmente, ela é o local do milagre porque encaminha os mortos para a nova vida, simbolizando, portanto, a imortalidade.

Essa figura da natureza, que compõe o imaginário dos dois autores, evoca uma forma de conhecer que está por vir, um novo conhecimento que, no dizer não ficcional de Mia Couto ${ }^{599}$, tem, como pressuposto, "conhecermos não para sermos donos, mas para sermos mais companheiros das criaturas vivas e não vivas com quem partilhamos este universo".

Ambos sugerem que o novo conhecimento não pode ser apreendido exclusivamente por conceitos, nem tampouco ser neles aprisionado, dada a infinita complexidade e transitoriedade humana.

\footnotetext{
${ }^{594}$ COUTO, Mia. Contos do nascer da terra. 6.ed., Lisboa, Editorial Caminho, 2006. p.111.

595 Afirmação feita em entrevista dada por Mia Couto por ocasião da FLIP, em 11 julho de 2007, na TV Cultura.

${ }^{596}$ COUTO, Mia. A varanda do frangipani. 7.ed., Lisboa, Editorial Caminho, 2003. p. 68.

${ }^{597}$ Idem, ibidem. p. 151.

${ }^{598}$ COUTO, Mia. Contos do nascer da terra. 6.ed., Lisboa, Editorial Caminho, 2006. p. 226.

${ }^{599}$ COUTO, Mia. Pensatempos: textos de opinião. 2.ed., Lisboa, Editorial Caminho, 2005. p. 49.
} 
Dessa forma, na visão desses escritores, o paradigma ocidental parece ter se esgotado.

Seus textos, embora ressoem elementos geográficos, culturais e históricos, abrem-se ao universal, porque oferecem ao leitor um novo olhar, hesitante, desconfiado diante do que aparece como natural. Mediante a desconfiança fertilizada pelo encantamento, o leitor se mantém em suspenso - condição que o motiva a indagar. O objeto de seu questionamento é o paradigma da certeza. Nesse paradigma, a força controladora age sobre o previsto, dentro de um padrão esperado e considerado normal. Tanto Manoel de Barros quanto Mia Couto inviabilizam essa força dominante fundada na normalidade servil para sugerir um outro paradigma alicerçado na incerteza, no acaso, no imprevisto e no imprevisível. Devolvem, assim, ao homem a possibilidade de surpreender-se.

Ambos apostam em um leitor errante e livre. Manoel de Barros aposta em um ser que se desfaz, que deslê; Mia Couto aponta para um ser em busca de sua própria identidade. Um convida a desidentificar-se, o outro torna a identidade motivo de sua trajetória. Um sustenta a construção de um ser a-histórico, o outro quer fazerse sujeito da história. São dois momentos de uma trajetória iniciática.

Enquanto o homem de Mia Couto está em travessia e necessita resguardar seu mundo santificado, o homem de Manoel de Barros necessita consagrar-se novamente.

O cosmos poético de Manoel de Barros, assim como o cosmos ficcional de Mia Couto mostram a importância desta re-ligação com o transcendente. Mia Couto insiste em mostrar o que é característico da sociedade tradicional africana. Manoel de Barros reinventa. Um registra em invenção o que já é, o outro reinventa o que não é mais. Este projeta aquilo que a cultura ocidental cegou, aquele faz questão de valorizar antes que o progresso e a modernidade rasurem.

Mia Couto enlaça o passado enquanto caminha para o futuro; Manoel de Barros carrega o futuro nas costas ao avançar para o passado.

Com escritas sem linearidade, fragmentadas, labirínticas, amparadas pela errância das palavras, das frases, dos sentidos, os dois autores acabam por ensinar o homem a perder-se para se conhecer, a sair do curso para experimentar o novo, para compartilhar com o movimento inacabado e incerto do mundo. Rompem com o conceito de leitura como tarefa de passar linearmente os olhos para decodificar signos e instauram o exercício de recriar pela inquietação. Transformam a 
percepção do leitor: em vez de ele se questionar "o que isso quer dizer", passa a indagar: por que isso está sendo dito? Por que é dito dessa maneira? Tudo porque a linguagem singular, com que inventam seus textos, deixa o leitor perplexo em sua saudável irreverência de perturbar o paradigma vigente.

Os dois ensinam-nos a estar sempre prontos para o inesperado, assim como para a aventura imprevisível da vida. Seus textos levam-nos ao passado, abrindonos ao imprevisível futuro. Convida-nos a alcançar a humanidade em nós mesmos.

Muitos temas sociais e históricos deslocam-se para a arte literária e, graças ao poder engendrado pela ficção, nessa práxis instaurada pela linguagem, ganham resolução estética e são capazes de impulsionar uma resolução real. No entendimento de Walter Benjamin ${ }^{600}$, cada época sonha a próxima, e, ao sonhar, força-a a acordar.

Consciente de seu ofício, tanto Manoel de Barros quanto Mia Couto sonham uma nova ordem para o Brasil, para Moçambique e para o mundo, e o fazem, simbolicamente, desordenando as formas, dispondo-as em uma ordem nova.

Com esse intuito, o escritor deixa clara sua adesão à função da arte literária, que, conforme Ernst Fischer 601 "concerne sempre ao homem total, capacita o Eu a identificar-se com a vida de outros, capacita-o a incorporar a si aquilo que ele não é, mas tem possibilidade de ser".

Para Mia Couto ${ }^{602}$, interessa a Nação que se configura na alma humana: "mas a primeira cidadania é a de uma nação que há dentro de cada um de nós". Deixa claro que acredita no homem, independente de sua etnia, de sua cor, como se lê em Terra Sonâmbula:

- Não gosto de pretos, Kindzu.

- Como? Então gosta de quem? Dos brancos?

- Também não.

- Já sei: gosta de indianos, gosta de sua raça.

- Não. Eu gosto de homens que não tem raça. É por isso que eu gosto de si, Kindzu. ${ }^{603}$

${ }^{600}$ BENJAMIN, Walter. Magia e técnica, arte e política: ensaios sobre literatura e história da cultura. Trad. Sérgio Paulo Rouanet. 7. ed., São Paulo, Brasiliense, 1994. (Obras Escolhidas, 1). p.222-232.

${ }^{601}$ FISCHER, Ernst. A necessidade da arte. Trad. Leandro Konder. 9.ed., Rio de Janeiro, Guanabara Koogan, 2002. p, 19.

${ }^{602}$ COUTO, Mia. Pensatempos: textos de opinião. 2.ed., Lisboa, Editorial Caminho, 2005. p.95.

${ }^{603}$ COUTO, Mia. Terra Sonâmbula. 8.ed., Lisboa, Editorial Caminho, 2004. p.31. 
O africano acredita, especialmente, nos homens capazes de olhar para dentro, como o miúdo do conto "o coração do menino e o menino do coração", em Contos do nascer da terra. Esses, em geral, são seres de exceção. O menino possuía pés enviesados. E a avó dizia: "esse menino vai caminhar para dentro dele mesmo". Além disso, o garoto falava uma língua de cuspes e assobios e tinha o pulsar à flor da pele. Se uns andam na lua, a lua é que andava nele. Seu coração deu origem a uma nova criança, agora com os pés não mais convergentes, mas divergentes, como se viesse procurar, fora de si, gente de outras estórias. O conto nos sugere que, primeiro, é preciso conhecer-se, olhar para si, para depois se buscar nos outros.

Agora, encontrado em si, esse menino pode se tornar parceiro de Bernardo nascido do ventre poético de Manoel de Barros - e prosseguir, a esmo, ultrapassando as fronteiras, no pulsar permanente dos inícios.

Por tratar de meninos e travessias, nosso intuito, agora, é comparar as duas obras infantis apresentadas no decurso deste trabalho e analisadas, em um corte mais vertical, a fim de mostrar a presença do sagrado nas duas linguagens que compõem os livros para crianças e jovens. Segundo Nelly Novaes Coelho ${ }^{604}$, mais do que um mero entretenimento, a literatura infantil é uma aventura espiritual que associa o eu a uma experiência vital.

\subsection{Para "despersianar" os olhos}

É com o olhar "religado" com o sagrado do mundo que propomos nossa leitura comparativa de Poeminhas pescados numa fala de João, do brasileiro Manuel de Barros e de O gato e o escuro, do moçambicano Mia Couto.

O livro Poeminhas pescados numa fala de João compõe-se de dez poemas, ilustrados por Ana Raquel, que colocam o leitor em viagem sagrada, entre o mirar terreno da janela do trem (cujos trilhos percorrem a parte inferior de todas as páginas do livro) e o olhar aéreo no dorso das andorinhas (que atravessam o espaço superior das páginas). É assim, com esse espírito de andarilho que o leitor pisa a Terra, mergulha nas águas, transubstancia-se em peixe, pato, cobra, pássaro,

${ }^{604}$ COELHO, Nelly Novaes. Literatura infantil: teoria, análise e didática. 6.ed. rev., São Paulo, Ática, 1993. p.28. 
encontra-se com a Noite, escuta o rio interior, ganha asas e alça vôo de andorinha a explorar o vento.

O livro O Gato e o Escuro, de Mia Couto, brilhantemente ilustrado por Danuta Wojeiechowska enreda o leitor em sua prosa poética, arrastando-o para "o lado de além da claridade". Nessa "trespassagem" imaginária do claro ao escuro, do dia para a noite, o leitor cruza as fronteiras do mundo ordinário e, em estado de enlevo, penetra no reino do extraordinário - percurso sagrado por excelência.

Sagrado, também, é o ato criador desses autores de texto verbal e visual; sagrado é o ato recriador da leitura, por serem ambos cosmogônicos por natureza. Criar é dar origem ao novo por meio de uma força mágica, sobrenatural. Mircea Eliade ensina que toda criação é simbólica, é um modelo cosmogônico por natureza, pois repete, ritualmente, a criação primeira, a que se deu ab origine, portanto está revestida de transcendência, de poder divino, de sacralidade.

Nas obras em análise, nada vem pronto, as imagens são apenas sugeridas e se transformam na imaginação do leitor, ganhando traços de encantamento qualitativamente distintos do mundo ordinário, lógico, repetitivo, homogêneo, objetivo, prosaico.

Tanto em Manoel de Barros quanto em Mia Couto, o leitor entra em contato com o transcendente por meio da natureza. Nas duas obras, a natureza manifestase qualitativamente diferente. Em Manoel de Barros, "A Noite caiu da árvore"; "o boi piou cheio de folhas com água"; em Mia Couto, o gato preto estava "enroscado do outro lado do mundo"; "o escuro se encolheu, ataratonto". Nas duas obras, a natureza importa tanto a ponto de ganhar estatuto de ser humano, personificar-se.

Ambos os autores valem-se das combinações de imagens características do pensamento mágico e mítico, grávido de maravilhoso, em que tudo se transforma em tudo. Nascido da necessidade de explicar fatos desconhecidos, o mito, esse narrar artístico primordial do homem, rememorado aqui pelos autores, constrói-se por metamorfoses, milagres, pelo impossível. Em Manoel de Barros: "João foi na casa do peixe", "meu bolso teve um sol com passarinhos", "A Noite caiu da árvore. Maria pegou ela pra criar e ficou preta", "o sapo de pau virou chão", "o cocô de capiravas era rodelinhas-bola de gude"605. Em Mia Couto: "Certa vez, inspirou coragem e passou uma perna para o lado de lá, onde a noite se enrosca a dormir",

${ }^{605}$ É característica de Manoel de Barros valorizar elementos escatológicos para construir sua cosmogonia. 
"Só quando desaguou na outra margem do tempo ele ousou despersianar os olhos", "E os olhos do escuro se amarelaram". Enfim, em ambos os autores, o universo apresenta-se como plástico e fluido, pondo em relevo as qualidades do sentir: a intuição, a emoção, a sensibilidade, a experiência concreta - características do pensamento mágico e de um estar no mundo do qual participa o sagrado.

Essas qualidades que revelam um olhar primeiro, livre, des-aprendido, desexplicado, extra-ordinário, aproximam as referidas obras de seus leitores-crianças e, ao mesmo tempo, irmanam as duas culturas: brasileira e africana.

Outro elemento resgatado pelos autores e capaz de assemelhar as duas culturas e, igualmente, provocar diálogo das obras com a criança é a forma com que todas essas imagens inaugurais são codificadas: a oralidade.

Manoel de Barros pesca os poemas da fala de João e, por isso, traz as marcas dessa oralidade: onomatopéias: tibum, pan, pum; construções sintáticas inusitadas: "ficou todo molhado de peixe", "eu se chorei"; desvios da norma culta: "tinha dois pato grande". "Maria pegou ela" "a gente pega ele pelo rabo; construções próprias da fala infantil feitas por analogia com os tempos verbais regulares: "Veio Maria-preta fazeu três araçás pra mim", "você viu um passarinho abrido"; uso de aumentativo e diminutivo para conferir dramaticidade ao discurso e ampliar o traço heróico do "contador": de dia apareceu uma cobrona debaixo de João. Eu matei a boca pequenininha daquela cobra"; regionalismos: "Ninguém não tinha um rosto com chão perto", "minha boca estava seca igual do que uma pedra"; neologismos e repetições: "meu lambarizinho/escapuliu-ele priscava/priscava".

Mia Couto propõe travessia tanto no plano do conteúdo quanto no plano da expressão. Assim como o gato rompe a fronteira do conhecido, do permitido, do estabelecido, do uso ordinário do verbo, rompe também o autor, no plano da forma, com expressões que cruzam as fronteiras do esperado, da norma-padrão e atingem o inesperado, o imprevisível. Construções sintáticas inusitadas: "gostava passearse"; neologismos: "trespassagem", "namoriscando", pirilampejavam", "tiquetaqueava", "noitidão," "despersianar"; "gateza"; "arcoiriscando" "estremolhado"; uso do vocativo revelando a conversa com o leitor e resgatando o papel do contador: "Vejam, meus filhos", "conta a mãe", "Aconteceu assim", "faz mais de conta ainda", "Adivinham?".

Tanto o brasileiro quanto o moçambicano resgatam, com esses recursos, a tradição oral - marca identitária das duas culturas. Manoel de Barros mostra nos 
escritos finais de sua obra: "Língua de criança é imagem/ da língua primitiva/ Na criança fala o índio, a árvore, o vento/ $\mathrm{Na}$ criança fala o passarinho/ $\mathrm{O}$ riacho por cima das pedras soletra os meninos./ Na criança os musgos desfalam, desfazem-se/ Os nomes são desnomes./ Os sapos andam na rua de chapéu./ os homens se vestem de folhas no mato/ A língua das crianças contam a infância/ em tatibitati e gestos." Mia Couto, em entrevista a Sophia Beal, em Portugal, março de $2005^{606}$ afirma: "os momentos que eu "estou" escritor são os momentos na minha vida em que tenho uma relação com o mundo, com os outros, com as coisas, com os seres, que é uma relação em que me permite ser criativo, me permite estar num estado de infância e em que estou olhando o mundo como alguém que ainda está se surpreendendo com ele".

A viagem proposta pelos dois autores convida-nos a romper com o prosaico e profano e reinventar os modos arcaicos de expressão: o poético e o sagrado. As formas dos textos, poesia e prosa - que, à luz das teorias, parecem distintas, sob o prisma de suas origens arcaicas e sagradas, assemelham-se. A poesia e o conto nascem na oralidade, deitam suas raízes na mesma nascente: o mitopoético. 0 canto primitivo que contava as descobertas, as lutas humanas, o nascimento, 0 casamento, a morte, as façanhas heróicas aliavam o poético e o sagrado.

O poético da linguagem abre múltiplas leituras, faz-se pela analogia, pelas comparações implícitas, pela metáfora, pela metonímia, linguagem que figura o uso "estranhado" do verbo.

Em Manoel de Barros:

\author{
Escuto o meu rio: \\ é uma cobra \\ de água andando \\ por dentro de meu olho
}

Ou em Mia Couto: "Vejam, meus filhos, o gatinho preto, sentado no cimo desta história."; "Por que razão o mundo se embrulhava num pano preto?"

Significativa a imagem do olho nas duas obras, mais forte em Mia Couto - em que, pelo olho da mãe, Pintalgato se vê e encontra sua identidade, convidando-nos a fazer a travessia e despersianar os olhos - e curiosa, em Manoel de Barros,

${ }^{606}$ Disponível em: www.lainsignia.org/2005/marzo/cul_030.htm. Acesso em: 15 de março de 2006. 
mostrada como o lugar marcado da travessia entre o mundo interior e o exterior no texto verbal ("Escuto o meu rio:/é uma cobra/de água andando/por dentro de meu olho") e, no texto visual, com a composição da capa e contracapa em forma de espelhamento. A relação da percepção-consciência passa pelo olhar e desdobra-se, nas duas obras, pela imagem do espelho - objeto a partir do qual Pierre Mabile ${ }^{607}$ definiu o parentesco entre se mirer (mirar-se) e merveille, maravilha. Atravessar o livro, para os dois autores, é atravessar para o outro lado do mundo, a fim de compreender, pelo estranhamento, pelo lado outro, as infinitas possibilidades de libertação, de transgredir a lógica cotidiana e profana e emancipar-se pelas fulgurações do sagrado.

As imagens do olho e do espelho reiteram o movimento cíclico, marcando, profundamente, as duas obras e tornando-as coesas com a dimensão ritual sagrada.

Se o tempo profano é homogêneo, contínuo, linear, histórico, irreversível, o tempo sagrado é heterogêneo, descontínuo, circular e a-histórico, reversível, possibilitando o eterno retorno, no ensinamento de Mircea Eliade.

Em Poeminhas Pescados numa fala de João, é a ilustradora quem pesca, com sensibilidade, esse movimento sagrado da natureza, marcado no código visual pelas andorinhas que, entre a capa e a contracapa, voam em círculo - movimento reafirmado pela presença do trem, que sugere a travessia das páginas-vida, e pela composição em espelhamento.

Em O gato e o escuro, o leitor também é convidado a ir e voltar na estória. $\mathrm{O}$ movimento cíclico é sugerido, na linguagem verbal, pela fala inicial do narrador: ("Vejam, meus filhos, o gatinho preto, sentado no cimo desta história. Pois ele nem sempre foi dessa cor.") e pela fala final: ("Então, o gatinho Pintalgato espreitou nessa fenda escura como se vislumbrasse o abismo. Por detrás dessa fenda o que é que ele viu? Adivinham? Pois ele viu um gato preto, enroscado do outro lado do mundo."). Também fica evidenciado o ritmo cíclico da natureza pela escolha do sol e da lua, representativos do dia e da noite - espaço da travessia. É um rito natural que se mostra. Simbolicamente, com a noite, rememoram-se as trevas pré-natais, a escatologia, e, com o dia, o nascer do sol, a cosmogonia - para Mircea Eliade, movimento sagrado por excelência. Na linguagem visual, esse gesto exemplar ritual, cíclico, é apresentado, metonimicamente, pela ilustração em malhas, pintas e

${ }^{607}$ MABILE apud TODOROV, Tzvetan. Introdução à literatura fantástica. São Paulo, Perspectiva, 2004. p.130. 
caras de gatos amarelos que se repetem no início e no final do livro em páginas duplas e, na capa e contracapa, em que se repete a imagem do olho. Na contracapa, a metáfora do olho-janela, com a qual a ilustradora maravilhosamente traz, ao patamar dos olhos, o teatro do mundo, reiterando o trajeto que leva do visível ao invisível, do ordinário ao extraordinário, do profano ao sagrado, reconhecidos na espessura da existência.

Tanto Manoel de Barros quanto Mia Couto reinventam o canto arcaico na sua espontaneidade, no ritmo imanente da fala, no pulsar inesperado das imagens, nos desvios e peraltices possíveis da oralidade, afirmando um discurso livre de toda dominação escrita. A prosa de Mia Couto permanece no nível da imagem, não se preocupa com conceitos, depura-se no sensível. Ambos auscultam a natureza interna e externa, ouvem o sussurrar do cosmos e plasmam essas sensações em imagens, entoam os movimentos da alma, em fulgurações sagradas e é isso que nos arrebata. Ambos deixam entrever, no novo da aparência, o originário e eterno da essência. Os autores resgatam o poder originário da linguagem de nomear, de compreender a natureza e, nesse ato mágico, resgatam o "ser" da poesia de que fala Alfredo Bosi ${ }^{608}$, para bem além de seu mísero existir. Com os autores, o poético não sobrevive, ele revive em plenitude.

Não se pode desconsiderar o caráter histórico da consciência que organizou as obras, tampouco se pode olvidar a História, a formação social, a ideologia, a cultura em que se insere cada uma delas. Cabe-nos, portanto, analisar que sentido tem a travessia de um gato para a cultura moçambicana? E de imagens da natureza pescadas na fala de João?

É fato que, pelas dobras do sagrado, plasmando uma travessia iniciática, Mia Couto traz à luz seu projeto estético e político. O gato e o escuro é a forma que esse autor encontrou para revelar a situação de busca de si vivida pelos moçambicanos. Visão, imaginação, palavra, em parentesco com fantasia, instauram uma nova maneira de conhecer-ver. Resgata-se, no jogo do olhar, a questão da identidade tão importante aos escritores portugueses do pós-colonialismo.

Ao transgredir o limite e a ordem estabelecida, Pintalgato abraça o sonho da liberdade, da independência, da autodescoberta, lança-se na construção de sua

608 "Essas formas estranhas pelas quais o poético sobrevive em um meio hostil ou surdo não constituem o ser da poesia, mas apenas o seu modo historicamente possível de existir no interior do processo capitalista"(BOSI, Alfredo. O ser e o tempo da poesia. 6.ed., São Paulo, Cia das Letras, 2000. p.165). 
própria identidade ou de suas várias identidades. A voz da mãe reanima a voz da Terra, lugar em que essas identidades se enraízam. A palavra dos mais velhos reafirma a cultura da oralidade, da tradição. A mãe detém o saber sobre os mais profundos segredos da tessitura existencial do filho e, vendo-se nos olhos dela, ele se encontra.

Mia Couto propõe uma sagração da natureza, daí as personagens serem animais, e os elementos referenciais da travessia serem o sol e a lua. $O$ par visão X cegueira revela o atributo normalmente conferido ao animal gato: a clarividência. Remete, também, ao processo de alienação e de consciência que envolve o amadurecimento de todo homem e fundamenta sua possibilidade de ação e de transformação no mundo. Mia Couto, encarnado em Pintalgato, recusa a domesticação do espírito, inaugurando a ousadia.

Assim, o texto moçambicano recupera o imaginário de sua cultura, com elementos de sua própria tradição. Mia Couto reinventa o olhar, rompe com a experiência domesticadora do ver, propondo uma experiência insólita, renovadora, epifânica, sagrada. Traz à memória o olhar profundo e mágico da infância dos tempos em que ser curioso, corajoso e livre era a lei.

A voz moçambicana de Mia Couto coloca-nos, no patamar dos olhos, uma África-menina que se permite transgredir, possibilitando, assim, revisar e de reverter valores instituídos pelo poder do outro. O tempo da memória, nesta obra, é parceiro do tempo do porvir, ambos compõem um cenário em que se olhar é abrir os canais para fazer a própria história. Na "trespassagem" de Mia Couto, revela-se o caminho iniciático dos moçambicanos, e de muitos africanos. Pintalgato recusa a obediência, lança-se à descoberta e à liberdade. Transitando entre o sol e a lua, no espaço mágico das zonas fronteiriças, constrói-se uma transformação libertária.

Quem olha, olha de algum lugar. Projetado em Pintalgato, Mia Couto observa do cimo, do alto e de longe, vigia, protege, comunica, sonha sua mensagem. Reflete, pondera, marca seu eminente olhar. Misto de antigo poeta, sábio, filósofo e adivinho, faz perceber, o inusitado, o 'mirus' - o maravilhoso. Com sua mirada, põe à vista a literatura-arte-admiração. Admirado é o olhar que vê o milagre 'miraculum'. Maravilhados são os olhos que perscrutam a vidência perfeita evidência. Esta é a perspectiva de Mia Couto que conjuga no espectador-leitor a curiosidade de ver para frente e de ver em profundidade realidades existenciais que 
escapam ao olhar comum. Nessa composição de imagens, o olhar revela o sentir enlaçado ao pensar.

Mia Couto alinhava as malhas de um tecido imaginário que é próprio de sua cultura de origem: animais, sol, lua, elementos que se coadunam com o mito. Recupera uma imaginação que abre frestas para a viagem, consubstanciando sua pulsão pela liberdade. Lançando-se à transgressão, em uma realidade em que isso, por princípio, era inaceitável, Pintalgato torna-se signo da resistência.

No fazer-crer de Mia Couto, o encontro do velho e do novo, da mãe e do filho, apresenta um valor caro à cultura africana, que deseja o futuro, ciosa de suas tradições. No fio da voz que narra, no suporte aglutinador da língua, à revelia de toda norma, abrem-se caminhos e desenhos do que se arquiteta como grito pela invenção silenciosa de palavras.

Como já enunciamos, Pintalgato sai a passeio pela "linha onde o dia faz fronteira com a noite", atravessa a luz, vence o limite, penetra no escuro disforme "a noitidão" e deságua na outra margem do tempo-interior-imaginação, até retornar ao cimo da estória - ascensão equivalente à subida ao céu. Junto a ele, peregrina o leitor: de ser passa a não-ser até engendrar-se em novo ser. Eis a narrativatravessia. Eis um novo povo que se forma, capaz de atravessar sua própria história e, no cimo, ascender de objeto a sujeito. Ensina Guimarães Rosa ${ }^{609}$ pela voz de Riobaldo: "Qual é o caminho certo da gente? nem para frente nem pra trás: só para cima."

Assim, nessa busca de si que se depreende um traço significativo da literatura africana atual em sua missão de participar da construção de novas formas de estar no mundo, de olhar o outro e a si.

Manoel de Barros pesca o sagrado na fala de João. A língua de Manoel de Barros esconde, em seu estado de fala, encantamentos. Com ela, é possível verter e reverter a escrita. Nela se inscreve uma gramática do chão brasileiro para a qual o escritor tem olhos sensíveis: vê, aproxima-se das palavras, espreita seus significados, descobre novos sentidos.

Com onomatopéias, o poema ganha som, com metáforas e metonímias, o poema ganha cor, forma, visibilidade, com as combinações sinestésicas, o poema ganha cheiro, toque, ganha os sentidos. Reconciliado com o movimento da

${ }^{609}$ ROSA, Guimarães. Grande Sertão: veredas. Rio de Janeiro, Nova Fronteira, 1986. p.78. 
natureza, o poema ganha o tom e o chão brasileiro. Desfilam, na paisagem poética verbal e visual, a fauna, flora e a alma de um Brasil-criança viva e virgem de toda exploração. Cores da terra, sons que anunciam aberturas de formas e cheiros da nossa terra, imagens que se afinam com o compasso da terra brasilis. Por entre as folhas das árvores, por entre os cantos dos pássaros, sussurra a voz de nossos ancestrais, nossa fala mais genuína, percebe-se nosso olhar primeiro, primitivo, inaugural, coeso com a natureza. Por isso, sua poesia é resistência, recusa o desmatamento da alma brasileira, resiste a toda civilização, nega a sociedade capitalista que nos encarcera.

A imagem mais sensível do poeta, reveladora de seu sonho diurno é a andorinha, que acompanha o leitor em sua travessia. Sabe-se que todo animal alado tem vínculo com o sagrado. Sabe-se, também, que a andorinha é ave comum à fauna brasileira.

Interessante observar que os dez poemas ilustrados por Ana Raquel foram retirados do livro Compêndio para uso dos pássaros, especificamente da Parte I, que se intitula: "De meninos e de pássaros". Com isso, se evidenciam os dois elementos que compõem, fortemente, o sonho diurno ${ }^{610}$ do autor: a infância e a ave.

Ouve-se, nas frestas silenciosas de seu mosaico poético, um grito em favor de uma nação que, a cada dia, tem sucumbido ao poder dominante, deixando à mostra, na sua natureza, as mazelas da exploração.

A mesma relação que ele estabelece com a natureza, ele o faz com a língua: a de libertação. Ainda que revele sua poesia como despropósito, por ser arte que deita raízes e dorme no leito brasileiro, põe a imaginação do leitor em revoada, para que ele, de fato, amanheça. A natureza é para ele um ventre poético que fecunda renovação. É o útero do qual nasce o encantamento da letra, os deslimites do verbo, o silêncio das peraltagens poéticas. O poeta inaugura um mundo outro em que o homem comunga com o sagrado. Manoel de Barros põe no chão todos os sentidos, leva aos ouvidos humanos sons, ritmos, sintaxes inusitadas, consagrando um mundo distinto do ordinário. Mostra-lhe o milagre do chão, a maravilha do que não se esgota, o encanto do que permanentemente se refaz. Transubstancia homem em

${ }^{610}$ Conforme Benjamin Abdala Junior, inspirado em Ernst Bloch: "é o sonho de quem procura novos horizontes [...] Essa atitude é mais adequada do que o sonho noturno, que teima obsessivamente em olhar para trás, melancolicamente contemplando as ruínas." (ABDALA JR. Benjamin. De vôos e ilhas: literaturas e comunitarismos. São Paulo, Ateliê editorial, 2003.p.18). 
natureza, devolve-lhe a origem, recolocando-o em estado de graça. Sua poesia é uma verdadeira celebração.

Manoel de Barros fala, em sua poesia, das coisas da origem, resgata o tempo mítico, primitivo. As palavras com que a constrói são palavras-brinquedos, passíveis de manusear. Sua linguagem se põe rasteira, próxima da coisa, portanto é concreta, simples, vizinha da língua adâmica, por isso seus versos são livres, soltos, desarticulados, distantes da linguagem adulta, culta, pensada, distante do estabelecido e próxima da criança.

A combinatória de imagens de forma surreal, aliada a uma linguagem sentida, tateada, ouvida, abre-nos a possibilidade de nos projetar para além do ordinário. Com Manuel de Barros, a poesia é devolvida às suas origens e nos devolve às origens, em um verdadeiro encontro com o extra-ordinário.

À guisa de conclusão, tanto Mia Couto quanto Manoel de Barros subvertem conteúdos e expressões do mundo profano, arremessando-nos em um território mágico em que as origens e as fronteiras transubstanciam-se em fonte de fruição estética.

Tanto a travessia aquática proposta por Manuel de Barros quanto a "trespassagem" anunciada por Mia Couto exprimem menos uma vontade de se deslocar fisicamente e muito mais uma sede de descobrir verdades.

Em suas travessias literárias, ambos convidam à busca. Viaja quem não está pronto: todos nós. Viagem é signo de aventura, de procura, motivada pela insatisfação, orientada para a busca de si.

Com as literaturas-travessia de Manoel de Barros e Mia Couto, viajamos para um tempo anterior à domesticação da natureza pelo homem, escavamos um tempo mítico, revisitamos os subterrâneos do sonho. A percepção que reveste a arte literária desses escritores é fonte renovadora de conhecimento e de transformação, de recusa e de reconciliação.

Contrariamente aos discursos dogmáticos, o sagrado revela-se, nas duas obras, como o reino da transgressão, a marca que universaliza a arte, semente que faz nascer literatura. Esse modo de ser, diverso do modo repetitivo da vida cotidiana, abre possibilidades à África e ao Brasil, herdeiros do mito e do místico, cada qual à sua maneira, de re-encontrarem suas identidades. O sagrado, nesses discursos, insurge-se como lugar libertário, não só porque rememora, miticamente, as origens da terra-mãe, mas também porque projeta o futuro, o devir, o sonho da comunhão 
do homem com a natureza, do homem consigo mesmo e do homem com os outros homens. Unidos pela mesma pátria: a língua, passageiros da mesma viagemtravessia: a arte da palavra, Mia Couto e Manoel de Barros enlaçam, nas visões do sagrado, as entrevisões do porvir. Muitas são as possibilidades, duas são as culturas: o sonho é Um.

No eixo-do-mundo-livro, em jogo de voz, letra e imagem, entre cantar, contar e ad-mirar, os criadores de texto verbal e visual, cada qual em sua linguagem, projetam paisagens estéticas que convidam o leitor à travessia sagrada. No Brasil, pela imersão na água; em África, pelo espaço sideral; os dois buscam-se nos limites das trevas para a luz, do Caos e do Cosmos. Com vocação mais para descobrir do que para ver, as constelações de verbo e imagem, em ambos os textos, lançam o leitor nos territórios sagrados da invenção, inscrevendo-lhe um olhar religioso como o olhar da criança.

\subsection{Os filhos da estrada/ Na zona fronteiriça}

Agora, temos condições de alinhavar nossas mais recentes percepções sobre a leitura comparada das obras de Manoel de Barros e Mia Couto. Assim como destacamos uma imagem que sintetiza as duas culturas e ganha um valor universal no nosso contexto de século XXI: a árvore - símbolo anunciador do novo conhecimento -, pretendemos colocar em relevo, aqui, uma nova visão de homem, que aproxima a personagem Bernardo, de Manoel de Barros, e Pintalgato, de Mia Couto: o viajante, na qualidade de andarilho.

$\mathrm{O}$ andarilho de Manoel de Barros usufrui o caminho até as origens. O de Mia Couto está em travessia (da tradição para a modernidade). Ambos estão sempre em caminho.

Para Michel Maffesoli ${ }^{611}$, a errância é uma condição fundadora da vida social. A figura do errante é sempre ambivalente. O aedo grego tem a característica de ser um viajante. Na Idade Média, a sede de outro lugar manifesta-se nas cruzadas, nos jograis, na figura do cavaleiro errante em busca de aventura do ideal amoroso. No Renascimento, essa aventura se incidiu sobre os mares com as Grandes Navegações, possibilitando a vivência da pluralidade estrutural que cada um carrega

${ }^{611}$ MAFFESOLI, Michel. Sobre o nomadismo: vagabundagens pós-modernas. Rio de Janeiro, Record, 2001. p.15. 
dentro de si. $\mathrm{O}$ vasto império português atesta esse espírito aventureiro e essa pulsão migratória. A saudade nasce desse sentimento de amor do longínquo. Para Gylberto Freire, em Casa grande e Senzala, essa pulsão migratória do português associa-se à arte de se misturar, à miscigenação. Com interesse de exploração, de povoamento, de expatriação, muitos tipos sociais se aventuraram por essas terras longínquas, reanimando o espírito de aventura de seus ancestrais e, ao mesmo tempo, fundando um novo espaço.

Há muitos exemplos que confirmam ser a cultura, em seu momento fundador, plural, marcada pela errância. Portanto, como afirma Michel Maffesoli 612 , "Um corpo social, qualquer que seja, guarda a memória de sua errância original". Um dos meios de reanimá-la é a literatura, que se vale de um recurso caro à vida de todo 'homo symbolicum': o Imaginário.

Somos viajantes, seres sempre em busca de outra parte, porque a inquietude e o desequilíbrio participam de todo elã vital.

O desejo de errância, observado em Pintalgato, mostra uma sede do infinito. A personagem revela, à sua maneira, o paradoxo contemporâneo da globalização do mundo, da sociedade que se diz positiva, domesticada pela razão instrumental nascida do lluminismo, pelo desenvolvimento tecnológico e pela ideologia econômica. Pintalgato move-se para o outro lado do mundo, o escuro, a sombra, o amorfo, o vazio, o silêncio. O que se move, em uma sociedade cristalizada por esses valores, escapa do poder. Pintalgato quebra os grilhões e os limites estabelecidos. Entre o sol e a lua, ele está em uma situação paradoxal que marca uma cultura nascente, o novo espírito do tempo.

Essa errância é a expressão de uma nova relação com o outro e com o mundo, o desejo de um outro lugar. Para isso, torna-lhe necessário transpor as fronteiras, transgredir o estabelecido, percorrer o vasto reino dionisíaco da sombra para experimentar as potencialidades próprias da aventura existencial.

Mobilidade e circulação, também, caracterizam a obra de Manoel de Barros, realizando, assim como a de Mia Couto, o ideal do Homo viator, do homem em viagem. Essa errância é vetor de encontro com o outro, movimento ímpar da travessia existencial.

612 MAFFESOLI, Michel. Sobre o nomadismo: vagabundagens pós-modernas. Rio de Janeiro, Record, 2001. p.53. 
Lembrando Michel Maffesoli613:

Existir é sair de si, é se abrir a um outro, ainda que através de uma transgressão. De resto, é a marcha transgressiva que sempre é o índice mais claro de uma energia ativa, de um poder vital se opondo ao poder mortífero das diversas formas de fechamento.

A errância, esse passeio sem destino, é o desejo de recusa ao estabelecido. Reclama uma vida mais aberta, pouco domesticada, como a aventura.

Curiosa a etimologia do verbo existir: 'ex' + 'sistere'. 'Ex' - indica procedência (de) e 'sistere', em grego 'ístemi'= sentido primitivo de botar de pé, levantar, erguer. ‘Existere’ é sair de, elevar-se acima de. Daí amplia-se para nascer e, finalmente, ser.

Toda mudança gera uma espécie de fascinação e de repulsa. O pensamento de mudança coloca o ser em perpétuo devir, põe à vista a inexorável transitoriedade das coisas, a sua evanescência trágica.

O esquema da fuga tem raízes arcaicas, funda o estado nascente, aquilo que foi um ato fundador. A marca da origem é sempre aventurosa. O nomadismo rememora essa aventura original. Nas obras dos dois autores analisados, esse movimento de errância é marcante.

Na África e no Brasil, o tema da fronteira desempenha papel importante na constituição do imaginário coletivo. O vagabundo, o andarilho é uma espécie de má consciência, pois rompe com a ordem estabelecida, põe-se a caminho, manifesta a pulsão do pioneiro, aquele que está à frente, que segura as rédeas de seu destino, fazendo-se sujeito de sua história, símbolo de um busca infinita de si, do outro, de uma sociedade em que os valores espirituais resultam da aventura coletiva. A fronteira, nesse sentido, é sempre movediça, de forma que a aventura possa continuar infinitamente. $\mathrm{Na}$ trajetória, o viajante testemunha o imprevisível, o estranho, o perigoso. No dinamismo de se movimentar, o transeunte permite-se transbordamentos afetivos.

A errância abre frestas para o intercâmbio, para as trocas - elemento básico de toda sociedade. Essa errância fundadora de que as sociedades humanas são fruto é o receptáculo da pluralidade e da mudança. É ela que sacode as certezas instituídas e os conformismos. Essa dinâmica favorece as recriações das relações,

${ }^{613}$ MAFFESOLI, Michel. Sobre o nomadismo: vagabundagens pós-modernas. Rio de Janeiro, Record, 2001. p. 32. 
das instituições, das obras coletivas, da cultura. A errância favorece o encontro com o outro.

Estamos em um momento de passagem, em que valores, regras, ideologias mostram-se esclerosados. Marchamos, como errantes, em busca de novos valores, novas formas de relação social, novas maneiras de ser, de pensar, de estar no mundo. A fase da mudança é sempre traumática, plena de tensões e destruições. Entretanto, sabe-se, é no vazio das ruínas que se aninha o vir-a-ser, o porvir.

Quanto mais as personagens das duas obras se lançam à irreprimível caminhada, tanto mais se desamarram/soltam das obrigações cotidianas. Assim, à medida da distância, da desterritorialização, tanto maior a espessura da vivência sagrada. Quanto mais sombras, escuros e noites, tanto mais densas as experiências interiores. A iniciação é a aprendizagem humana permanente.

Duas faces de uma mesma realidade: a busca de um eu limitado e consciente e, ao mesmo tempo, de um si aberto e disponível à alteridade do mundo; de um nós que necessita enraizar sua identidade a partir do encontro com o outro, passível apenas pela errância - dialética das culturas e da descoberta de si.

Pintalgato atualiza uma busca iniciatória, atravessando a paisagem: o sol e a lua. Com ele, agrega-se o leitor em viagem imaginária, igualmente em ritual de iniciação e passagem. Desgarra-se das certezas institucionalizadas e põe-se em busca, arrisca, ousa, pelas veredas da aventura iniciática.

É fato que, em um mundo aparentemente racional, uniformizado, em que se submete à ordem, acende-se o desejo de outro lugar. Assim é com Mia Couto, assim é com Manoel de Barros, assim é Pintalgato, Bernardo e tantas outras personagens de história e de estórias. Assim também é com o leitor. Todos partilham desse imaginário da errância. Só por meio dessa trajetória iniciática e sagrada, fruímos a vida em seu perpétuo recomeço.

Segundo Michel Maffesoli614, "a errância pós-moderna é aquela mesma que pode permitir lançar uma ponte entre o mundo contemporâneo e os valores tradicionais [...]" A marcha ou o êxodo de Pintalgato é simplesmente a passagem, a permanente transmutação, não há um lugar específico em que termina a trajetória, porque ela é cíclica, busca, simplesmente, a infinita transformação. Pintalgato é o filho da estrada, como Michel Maffesoli define o errante, uma identidade em

${ }^{614}$ MAFFESOLI, Michel. Sobre o nomadismo: vagabundagens pós-modernas. Rio de Janeiro, Record, 2001. p.112. 
movimento, ou seja, constrói-se de "identificações múltiplas", encarna o sonho coletivo do movimento, do desejo de outro lugar.

Manoel de Barros encaminha o leitor - andarilho das descobertas - em uma nova rota avessa ao culto do mercado e restauradora dos verdadeiros sentidos da existência.

Mia Couto sugere elementos para a construção do novo paradigma, Manoel de Barros apronta o leitor para construí-lo, porque ambos jogam com as idéias de 'demens', 'ludens', 'imaginarius' e 'poeticus', assinaladas por Edgar Morin ${ }^{615}$ como características do novo homem e do novo saber do século XXI.

Em momentos históricos diferentes, o brasileiro e o africano deixam marcas de algo que está em gestação. Ambos entrevêem o homem e seu errante sonho. Mia Couto abre caminhos, em uma nação-criança, nascida sob o signo da modernidade. Manoel de Barros, testemunhando um Brasil, comparativamente já velho, convida à expedição de retorno às origens. O primeiro recém-iniciado, 0 segundo em busca de nova iniciação. Os dois, sangrando de feridas até similares, descobertos na aprendizagem deles mesmos, acendem igual esperança e sonham a transformação. Se toda cultura humana se fundamenta em trocas de alma, Brasil e África dialogam-se pelas fulgurações do sagrado.

Como Mia Couto ${ }^{616}$ afirma: "Dois oceanos não separavam aquilo que a cultura e a História faziam vizinhos". Dois mundos costurados pelo sagrado e capazes de com ele tecer novos mundos.

Povoado de forças extraordinárias e energias fabulosas, o sagrado é capaz de operar o encantamento do mundo e, ao mesmo tempo, fornecer ao homem condições de atuar, significativamente, no mundo profano em que está inserido.

O livro é reclamado pelos dois autores como instrumento de cisão do homem com a natureza, distancia o homem do sensível e das origens, sendo lugar privilegiado da inscrição da cultura e da ideologia hegemônica. Entretanto, usam-no como veículo possível de transformação. Aproveitam-no para comunicar seu projeto e vocação em fazer da escrita um lugar possível da invenção da condição humana pela via do encantamento. Dessacralizado, o livro ressacraliza-se.

\footnotetext{
${ }^{615}$ MORIN, Edgar. Os sete saberes necessários à educação do futuro. 8. ed., São Paulo, Cortez, 2003.

${ }^{616}$ COUTO, Mia. Pensatempos: textos de opinião. 2.ed., Lisboa, Editorial Caminho, 2005. p.105.
} 


\title{
CONCLUSÃO
}

\author{
"o que faz andar a estrada? É \\ o sonho. Enquanto a gente \\ sonhar a estrada permanecerá \\ viva. É para isso que servem \\ os caminhos, para nos fazerem \\ parentes do futuro."
}

(Mia Couto)

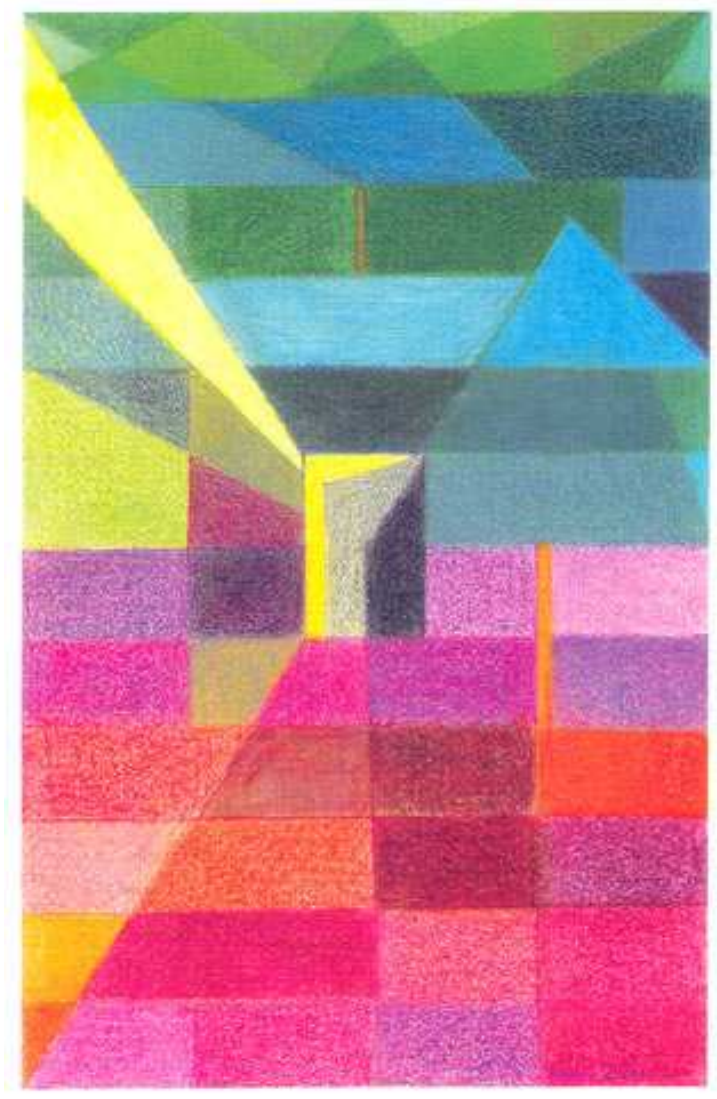

Ilustração 8 - arte de João Nasi Pereira para Mar me quer, de Mia Couto (2000) 


\subsection{Uma fresta que se abre}

Ao perscrutar o sagrado nas fronteiras da Antropologia e da Literatura, encontramos aspectos significativos sobre Brasil e Moçambique.

Se, como afirma Mircea Eliade ${ }^{617}$, a literatura prolonga o mito, narrativa fundadora oral, o sagrado já lhe é inerente.

Se toda criação recupera o gesto cosmogônico inicial e a literatura constituise como criação artística cuja matéria-prima é a palavra, sustenta-se afirmar que cada obra criada constitui-se como um cosmos, portanto seu processo de criação é sagrado.

A leitura, como processo de recriação, comporta, também, natureza sagrada, por refazer o ato criador exemplar.

Ao atentarmos para o que nos sopraram as obras de Manoel de Barros e Mia Couto, percebemos a presença do sagrado por meio de vários elementos.

Resguardadas as características históricas das culturas nas quais se manifesta - brasileira e moçambicana -, o espaço que os autores elegem para nos pôr em cena é a natureza. Ali nos colocamos em comunicação com o transcendente. Nela, fundam um espaço ecológico santificado, em que o leitor sacia a necessidade de sentido para o mistério da vida. Povoado de animais, vegetais, minerais e humanos, os autores plasmam um território imaginário em que se torna possível comungar com o sagrado. Com uma ecologia simbólica, reúnem elementos celestes, aquáticos, terrestres, solares, lunares, que retiram o leitor de seu espaço e tempo cotidianos e arremessam-no 'ab origine' 'in illo tempore'.

No complexo simbólico operado por Manoel de Barros, não encontramos predominância de simbolismos, mas uma convivência eqüitativa entre eles. Atribuímos isso ao fato de o autor projetar um espaço primordial, de inícios, em que todos os elementos têm igual importância na construção do mundo. Seu projeto é, de fato, desaprender um paradigma para construir um novo. Já em Mia Couto, observamos a predominância de dois simbolismos: o da terra e o da água. Atribuímos isso ao fato de o autor projetar um entrelugar em que se evidencia a travessia de um paradigma tradicional a um paradigma moderno.

${ }^{617}$ ELIADE, Mircea. Mito e realidade. Trad. Pola Civelli. 4.ed., São Paulo, Perspectiva, 1994. p.163. 
Entre as várias hierofanias que habitam o imaginário dos dois autores, destacamos a árvore. Essa ênfase nos soa interessante por evocar uma imagem capaz de aproximar não só as duas culturas, mas outras tantas, visto poder abraçar a idéia de um novo conhecimento que pressupõe mudança de paradigma, especialmente para as sociedades ocidentais, lugar de onde fala este pesquisador. Nesse novo paradigma, é preciso entrever a presença do sagrado. $E$ isso pode ser aprendido com a cultura africana. Esse novo paradigma aglutina o conhecimento complexo de que trata Edgar Morin. ${ }^{618}$ Complexo, derivado de 'complexus' tem sentido de trançar, enlaçar, tecer. Nesse enlaçamento, um novo humano deverá ser gestado - aquele que reúne, em especial, os atributos do 'homo sapiens' e de 'homo demens'.

O tempo em que ambos os autores nos lançam coaduna-se com o sagrado. Em Manoel de Barros, a origem do homem, da linguagem; em Mia Couto, a travessia. Ambos guardam forte presença do sagrado. Nos dois, a predominância do tempo mítico.

A maior parte das personagens que desfila nas paisagens estéticas dos autores estudados, comunga com o sagrado, porque, em seus nomes, carregam estórias versando sobre a própria existência humana, porque são reconciliadas com a natureza. Entre elas, se destacam velhos e novos: ambos guardiões, um do passado, o outro do futuro. Os velhos guardam a tradição, sendo considerados iluminados; os novos, as crianças, são portadores do olhar inaugural, primeiro, portanto associam-se ao sagrado.

Entre as diversas personagens que perambulam nas duas obras, ressaltamos a figura do viajante, ou do andarilho. Em Manoel de Barros, Bernardo; em Mia Couto, Pintalgato.

O andarilho é aquele que está sempre em trânsito, portanto, rompe as fronteiras fixas, as certezas; alarga margens e horizontes, sendo capaz de partilhar com todos, de agregar-se a outros. Em nossa visão, ele concretiza a proposta de travessia anunciada pela literatura comparada atual. Diante de uma pretensa democracia maculada pela indiferença e pelo individualismo, na solidariedade encontramos o propósito para vislumbrar um porvir mais humanitário. Relembrando

\footnotetext{
${ }^{618}$ MORIN, Edgar. Educar na era planetária: o pensamento complexo como método de aprendizagem no erro e na incerteza humana. São Paulo, Cortez, 2003.
} 
Benjamin Abdala Junior ${ }^{619}$ : "Num vetor oposto a esse crescente processo de desagregação, o comunitarismo pode favorecer uma agregação supranacional”.

A linguagem dos dois autores, em cujas margens fertilizamos nossas descobertas, inunda-se de sagrado. Tanto Mia Couto quanto Manoel de Barros fazem ressoar a magia da voz na artesania de suas letras, valorizam a escuta, que coloca os seres em diálogo, que arremessa o leitor aos círculos de estórias ao pé do fogo, em conjunção com a palavra poética, de sentido extra-ordinário, em espaços de ligação entre o chão e o céu.

Ambos os autores estabelecem esse vínculo por meio da Língua Portuguesa. Ela oferece a possibilidade de irmanar essas experiências sagradas. Lúdica, afetiva e festiva, a língua - com a qual os autores nos ensinam a lidar com o imprevisível e com o inaugural - aproxima-nos do sagrado.

Ambos, com uma escrita literária fecundada pela oralidade e grávida de elementos imagéticos, simbólicos e sacralizados buscam suas raízes culturais e seus sentimentos de pertença. Não Ihes faltam inventividade nem sensibilidade para fazer fruir o verbo e colocar a palavra em festa.

Entre os tantos recursos estilísticos que traduzem a imagética dos dois alquimistas da linguagem, apostam na analogia que alicerça metáforas, metonímias, personificações, capazes de imprimir expressividade e afetividade aos textos como forma de manifestação do pensamento mágico, característico das sociedades tradicionais e das crianças, ou seja, daqueles que possuem um olhar religioso porque religado com o sagrado - sobre o mundo.

A escolha por recriar a tradição é a maneira que os dois inventores da língua encontram para restaurar a origem. Em Manoel de Barros, a entrevisão do primordial; em Mia Couto, a escuta dos antepassados. Em ambos, a qualidade da 'performance'.

Ambas as formas operam com a palavra falada, portadora de um misterioso poder criador, veículo do sagrado.

As marcas do sagrado fluem pelas bordas da poesia e do conto, respectivamente, gênero e forma escolhidos pelos autores para plasmar seus projetos políticos e estéticos.

${ }^{619}$ ABDALA JR. Benjamin. De vôos e ilhas: literaturas e comunitarismos. São Paulo, Ateliê editorial, 2003. p. 79. 
A poesia é linguagem inaugural por meio da qual se torna possível falar dos deuses e da criação do mundo. É de sua natureza amalgamar gestos e sons do modo primeiro de significar por meio de analogias características do discurso simbólico e articulado. Portanto, essa escolha de Manoel de Barros aproxima-nos do sagrado.

O conto literário, forma eleita por Mia Couto para cumprir seu projeto de liberação afetiva, inscrevendo a sociedade do ser na sociedade do ter, resgata o gesto vocal do contador e, trabalhado com a palavra mágica, enlaça o leitor na visão religiosa do mundo pelo poder de agregar os homens ao recompor a memória de uma experiência vivida.

A voz do narrador primordial que ressoa na prosa poética dos dois autores cumpre lembrar que Manoel de Barros, embora escreva predominantemente poesia, cria também prosa poética - rememora o tempo primeiro.

A presença do fantástico, do maravilhoso ou do surreal introduz o sagrado no domínio do milagre. Assim, os dois inscrevem o pensar mágico, a intervenção do onírico, a possibilidade da interferência do extraordinário no ordinário, do sobrenatural no natural.

Importante reconhecer que, embora os dois autores usem recursos da modernidade, como polifonia, metalinguagem, narradores mais dialéticos, entre outros, eles jamais perdem de vista os elementos do passado. E é com eles que ambos sacralizam suas obras, mostrando seu olhar religioso sobre o mundo, sobre a vida e sobre o homem. Exatamente o sagrado é a força capaz de assegurar as identidades e irmanar as duas culturas

No resgate desses elementos facilitadores da manifestação do sagrado, acabam por valorizar tudo que envolve a natureza da criança: o seu pensar, seu modo de estar no mundo, sua forma de agir, de falar, de brincar com as palavras, de criar, de se expressar. Com isso, injetam ser na sociedade do ter, imprimem voz nas ranhuras da letra, introduzem magia na aspereza do pensar estabelecido, inscrevem afetividade na atividade racional, paixão na razão, sentido no vazio da vida banal.

Importante considerar que o sagrado está presente, também, na linguagem visual que compõe as obras dirigidas às crianças. Nesse caso, os escritores, ao lado dos ilustradores atualizam o gesto cosmogônico primeiro e fazem com que o leitor se sinta criança e ganhe a possibilidade de olhar tudo como se fosse a primeira vez. 
Esse valor eternizado da criança aponta para uma sociabilidade em gestação. Essa é a sabedoria recusada pelo poder instituído.

Tanto o brasileiro quanto o moçambicano recorrem, sistematicamente, ao lugar simbólico da infância, grávido de sagrado, construindo uma espécie de passagem iniciática para o brotar de um novo homem, de um novo paradigma de pensar, sentir e querer humanos.

No tempo festivo da leitura, o leitor se encanta com o extraordinário e o mágico, fazendo das páginas do livro - objeto dessacralizado e obstacularizador do contato do homem com a natureza - seu lugar de iniciação.

Esse encontro com o sagrado proporcionado pelas obras de ambos os autores favorece uma apreensão do mundo pela sensibilidade. Isso encanta tanto as crianças quanto os adultos.

Por meio dessas cifras simbólicas, o leitor partilha do universal, recuperando sua natureza de animal simbólico, de 'homo significans'.

Os elementos transcendentes com que o leitor entra em contato pela via do imaginário fertilizam sua experiência vivida, potencializando transformações no porvir. Acreditamos ser a literatura terreno fértil da cultura, chão de criar e de projetar o homem, instrumento catalisador da conscientização e da transformação humana.

Reafirmamos a concepção de Nelly Novaes Coelho ${ }^{620}$ de que o valor literário de uma obra não pode ser mensurado por sua pertença a uma ou outra tendência literária, mas "pela consciência do fazer literário revelado por sua matéria literária, seu corpo verbal; e, também, pela adequação de tal matéria às forças renovadoras mais atuantes em seu momento de produção".

Podemos constatar que, tanto Manoel de Barros quanto Mia Couto, conscientes de seu ato cosmogônico, ecoam as forças renovadoras de sua época.

Interessante assinalar a visão de Michel Maffesoli ${ }^{621}$ sobre a pósmodernidade. Para ele, ela se define como "a sinergia de fenômenos arcaicos com o desenvolvimento tecnológico". Trata-se de uma construção plural, no sentido de compartilhada, não individualizada, lúdica, fundamentada na comunhão sensível dos homens, afetiva, estética, sensual, colorida, festiva. Por isso, mostra o autor a forte presença da figura mítica de Dionísio, em oposição a Prometeu, uma vez que, hoje,

${ }^{620}$ COELHO, Nelly Novaes. Panorama Histórico da Literatura Infantil/Juvenil. São Paulo: Quíron, 1985. p. 220

${ }^{621}$ MAFFESOLI, Michel. Notas sobre a pós-modernidade: o lugar faz o elo. Rio de Janeiro, Atlântica, 2004. p.21 
expressam-se as paixões, a "ética do instante" eterno, a temática noturna, o deus ctônico, o devaneio como jogo do mundo. Essa "centralidade subterrânea" funda a sociabilidade nascente na pós-modernidade.

Dionísio é uma espécie de nômade que perturba as certezas estabelecidas, introduz a desordem, a embriaguez, como maneira de domesticar a morte e como rejeição do tempo economizado. A pós-modernidade não se conforma com a unilateralidade do ideal solar. Elementos naturais, da terra, do primitivismo, das raízes, cada vez mais, têm sido recorrentes nas artes, convocando um saber mítico.

Em conjunção de sentidos, sugere Mia Couto ${ }^{622}$, em epígrafe de Contos do nascer da terra:

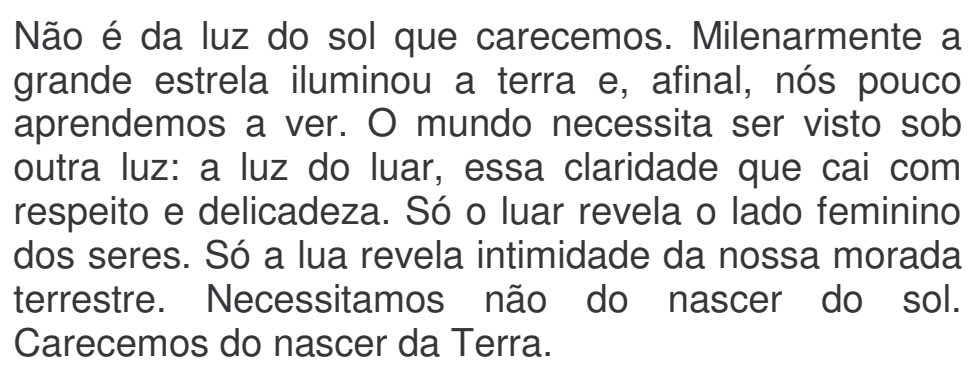

Continua Michel Maffesoli ${ }^{623}$, na mesma obra, afirmando que a força motriz da história é a experiência comum, "corolário do vivenciado", na qual se manifesta a sabedoria popular que põe em jogo "essa oscilação entre o bem e o mal, o escuro e o claro, o céu e a terra, em sua dinâmica própria, sublinha o que caracteriza o ser vivo."

Se vivemos a transição da razão solar para a razão sensível, se atravessamos do reino de Prometeu para o de Dionísio, é fato que a obra de Manoel de Barros e de Mia Couto nos sinalizam, ludicamente, essa experiência.

Os dois autores rompem com o modelo hegemônico masculino, adulto, técnico, ocidental, abrindo-se para um novo modelo civilizatório feminino, infantil, senil, multiétnico e multicultural, espalhando as sementes para a possível construção da sociedade-mundo, conforme concebe Edgar Morin ${ }^{624}$. Se ela acontecerá é incerto, mas muitos dos acontecimentos históricos felizes foram, em princípio,

\footnotetext{
${ }^{622}$ COUTO, Mia. Contos do nascer da terra. 6.ed., Lisboa, Editorial Caminho, 2006. p.7.

${ }^{623}$ MAFFESOLI, Michel. Notas sobre a pós-modernidade: o lugar faz o elo. Rio de Janeiro, Atlântica, 2004. p.99.

${ }^{624}$ MORIN, Edgar. Educar na era planetária: o pensamento complexo como método de aprendizagem no erro e na incerteza humana. São Paulo, Cortez, 2003. p.90.
} 
improváveis. Melhor acreditar em Guimarães Rosa ${ }^{625}$, quando nos ensina que "tudo, aliás, é a ponta de um mistério. Inclusive, os fatos. Ou a ausência deles [...]. Quando nada acontece há um milagre que não estamos vendo".

Tanto Manoel de Barros quanto Mia Couto envergam-se para o chão, revelando a natureza da sacralidade telúrica. Cabe pontuar, nas duas obras, que a Terra ganha caráter de mãe, 'Tellus Mater'. Essa percepção, no momento histórico em que vivemos, é de máxima importância diante da amarga destruição ambiental e das infinitas decorrências que amaldiçoam os homens no momento contemporâneo. Essa hierofania telúrica pode levar o leitor a ampliar o valor conferido a terra para searas universais, planetárias.

Mia Couto e Manoel de Barros abrem-nos os canais da percepção para questionar os efeitos de uma civilização reduzida ao qualitativo, ao dinheiro, ao prosaico, evocando a bandeira de uma sociedade-mundo, que abrigue, no mesmo lar, diferentes etnias, valorizando o sentimento de pertença e de enraizamento a uma Terra-pátria. Em travessia, perambulando por espaços múltiplos, eles reinventam um entrelugar motivador do diálogo das culturas, projetando uma nova forma de cidadania - a transfronteiriça e transcultural - e uma nova forma de identidade - sempre em curso.

Tanto o brasileiro quanto o africano, alimentados por seus sonhos diurnos, assumindo seu papel de viajantes pelas dobras do imaginário, recusam 0 conformismo. Sempre nômades. Sempre iniciados. Ambos, vetores do sagrado.

${ }^{625}$ ROSA, Guimarães. Primeiras estórias. 23.ed., Rio de Janeiro, Nova Fronteira, 1988. p.65. 


\section{IN-VOCAÇÃO \\ PARA A ERRÂNCIA}

"Talvez o nosso verdadeiro destino seja o de estar eternamente em caminho, sem parar de lastimar e desejando com nostalgia, sempre ávidos de repouso e sempre errantes. Só é sagrada de fato a estrada da qual não se conhece o fim $e$ que, entretanto, a gente se obstina a seguir. Assim, é nossa caminhada neste momento através da obscuridade e dos perigos sem saber o que nos

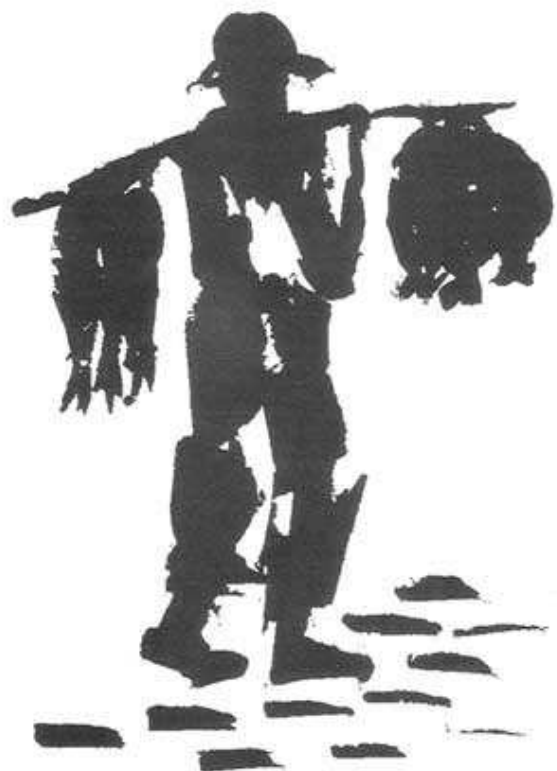
espera."

(S. Zweig)

Ilustração 9 - arte de Jorapimo para o livro Poemas concebidos sem pecados de Manoel de 


\section{O método como uma incerta viagem}

Compreendemos que teoria e método são componentes fundamentais do conhecimento científico. A teoria fornece-nos uma possibilidade de entrever os fatos. Em concordância com Edgar Morin ${ }^{626}$, ela não é o conhecimento, mas permite o conhecimento. Não é uma chegada, é a abertura para uma partida, assim como não é a solução, é a possibilidade de tratar um problema.

É comum remeter o conceito de método à teoria de Descartes, enfatizando a necessidade de partir de certezas estabelecidas de maneira ordenada e de regras permanentes a serem seguidas de forma mecânica. Assim, o método ganha característica de programa, composto por técnicas de produção e de reprodução do conhecimento. Entretanto, durante nosso percurso pelos territórios literários de Manoel de Barros e de Mia Couto, sentimos que a realidade é mutável, ela é incerta e se transforma. Portanto, esse território conceitual fechado causou-nos mal-estar, tornando-se insuficiente para tratarmos de nossas questões.

O método, em nosso trabalho, passa a ser compreendido como um caminho que se experimenta, "um ensaio gerativo", "uma estratégia para e do pensamento"627. Com isso, põe em cena a idéia de viagem, de travessia e suas múltiplas possibilidades de errância. Vale confessar as inúmeras vezes em que essas palavras e idéias foram tecidas e destecidas. E não se trata de improvisação, ou de arbitrariedade, mas da evidência de que aquele que quer encontrar algo se assemelha ao viajante-andarilho, sem orientação fixa, ser-em-busca. Com olhar atento, espreita as imagens que o mundo lhe concede, ouve as vozes daqueles com os quais dialoga, seres reais ou fictícios, liga-se a tudo, sem se prender a nada, porque seu destino é a errância. O sentido de sua caminhada está na mudança, por isso ele é nômade. No percurso, esse viajante enfrenta múltiplos obstáculos e encontra portas fechadas, outras entreabertas, tantas apenas encostadas. Alimentado pelo sonho, nunca desiste, porque acredita que a vida é sempre um feixe de possibilidades e, entre as fraturas do percurso, é capaz de entrever o sentido.

\footnotetext{
${ }^{626}$ MORIN, Edgar. Educar na era planetária: o pensamento complexo como método de aprendizagem no erro e na incerteza humana. São Paulo, Cortez, 2003. p.24.

${ }^{627}$ Idem, ibidem. p.18.
} 
Indisciplinada, nossa travessia-investigação traduz-se sagrada, povoada de rituais de iniciação e de passagem. Assim, o método, no contexto desta pesquisa, cumpre sublinhar, não precedeu a experiência, mas foi-se desenhando durante a travessia, assim como aprendizagem. De forma que o suposto acabamento deste trabalho não revela senão as marcas de seu próprio inacabamento.

Evidente que o caminho se iniciou a partir de algo e entrevia um fim. Assim, explicam-se as interferências das teorias que serviram de solo ao percurso deste pesquisador.

No decurso da errância, deparamo-nos com erros. E com eles fecundamos novos caminhos. Ensinou-nos Mia Couto ${ }^{628}$ : "se os genes nunca falhassem não haveria a diversidade necessária para a continuidade da Vida. Os processos vitais exigem, ao mesmo tempo, o rigor e o erro. Não podemos ter medo de não saber. $O$ que devemos recear é o não termos inquietação para passarmos a saber".

A errância pelos territórios do Brasil de Manoel de Barros e de África de Mia Couto fez-nos perceber uma nova ecologia: uma ecologia fecundada pelo sagrado.

A pulsão da aventura expulsou-nos para além de nossas fronteiras, nesse movimento permanente entre vida-fora-vida-dentro em que se tece a trajetória humana. Nessa circulação entre o eu e o outro, no movimento de afastar e acolher, assegurado pela liberdade do olhar, do sentir e do querer, estreitamos laços, afivelamos sentimentos e descobrimos nosso modo de estar no mundo pelo modo de estar do outro.

$\mathrm{Na}$ aprendizagem da errância, apreendemos o outro, de forma que a transcendência do caminho acabou por fundar a transcendência do acolhimento.

$\mathrm{Na}$ marcha da história, apreendemos a força do imaterial, os sinais do invisível, os tons do manifestado em silêncio.

Aprendemos que estar a caminho é sempre importante, ainda que esse caminho seja eternamente o meio.

[...] eu que não procurasse demasiado. Aprendesse a deixar os mistérios no seu devido estado. O homem sábio é o que sabe que há as coisas que nunca vai saber. Coisas maiores que o pensamento. ${ }^{629}$

\footnotetext{
${ }^{628}$ COUTO, Mia. Pensatempos: textos de opinião. 2.ed., Lisboa, Editorial Caminho, 2005. p.47.

${ }^{629}$ COUTO, Mia. Um rio chamado tempo, uma casa chamada terra. São Paulo, Companhia das Letras, 2003. p.159.
} 
“NO ÚLTIMO

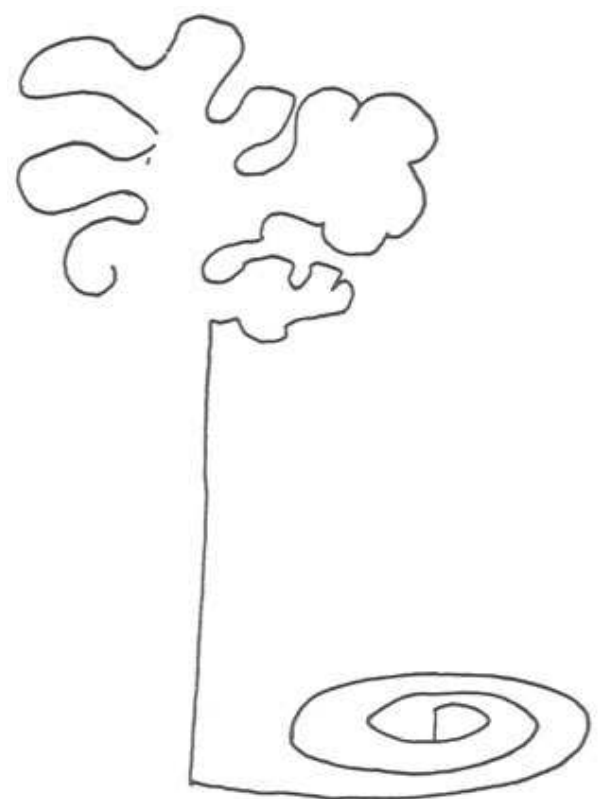

SUSPIRO

DOS

POENTES É QUE

PODEM EXISTIR

TODOS OS SÓIS".

(Mia Couto)

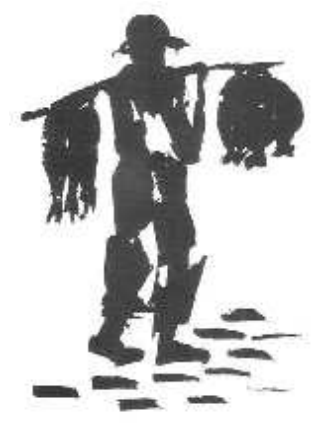

"as árvores me começam." 


\section{REFERÊNCIAS}

ABDALA JR., Benjamin. De vôos e ilhas: literaturas e comunitarismos. São Paulo, Ateliê Editorial, 2003.

- Fronteiras múltiplas, identidades plurais. São Paulo, Senac, 2002.

BANDEIRA, Manoel. Estrela da vida inteira. 16.ed., Rio de Janeiro, José Olympio, 1989.

BARROS, Manoel. Arranjos para assobio. 4.ed., Rio de Janeiro, Record, 2002.

. Cantigas por um passarinho à toa. Rio de Janeiro, Record, 2003

- Compêndio para uso dos pássaros. Rio de Janeiro, Record, 1999.

. Concerto a céu aberto para solos de ave. 4.ed., Rio de Janeiro, Record, 2004.

. Ensaios fotográficos. 5.ed., Rio de Janeiro, Record, 2005.

- Exercícios de ser criança. Rio de Janeiro, Salamandra, 1999.

. Gramática expositiva do chão. 5.ed., Rio de Janeiro, Record, 2006.

- II. Ana Raquel. Poeminhas pescados numa fala de João. Rio de Janeiro, Record, 2001.

- Livro de pré-coisas: roteiro para uma excursão poética no Pantanal. 4.ed., Rio de Janeiro, Record, 2003.

- Livro sobre o nada. 12.ed., Rio de Janeiro, Record, 2006.

- Matéria de poesia. 5.ed., Rio de Janeiro, Record, 2005.

. Memórias inventadas: a infância. São Paulo, Planeta, 2006.

. Memórias inventadas: a segunda infância. São Paulo, Planeta, 2006.

. O fazedor de amanhecer. Rio de Janeiro, Salamandra, 2001.

- O guardador de águas. 5.ed., Rio de Janeiro, Record, 2006.

- O livro das ignorãças. 12.ed., Rio de Janeiro, Record, 2006.

. Poemas concebidos sem pecado. 4.ed., Rio de Janeiro, Record, 2005.

. Poemas rupestres. Rio de Janeiro, Record, 2007.

- Retrato do artista quando coisa. 4.ed., Rio de Janeiro, Record, 2004.

- Tratado geral das grandezas do ínfimo. 3.ed., Rio de Janeiro, Record, 2005. 
BENJAMIN, Walter. Magia e técnica, arte e política: ensaios sobre literatura e história da cultura. Trad. Sérgio Paulo Rouanet. 7.ed., São Paulo, Brasiliense, 1994.

BÍBLIA SAGRADA. Trad. Centro Bíblico Católico. 21.ed., São Paulo, Edição Claretiana, 1975.

BORNHEIM, Gerd et al. Tradição/contradição. Rio de Janeiro, Zahar, 1987.

BOSI, Alfredo. O ser e o tempo da poesia. 6.ed., São Paulo, Companhia das Letras, 2000.

- Reflexões sobre a arte. 2. ed., São Paulo, Ática, 1986.

(org.). Leitura de poesia. São Paulo, Ática, 2003.

BOSI, Ecléa. Memória e sociedade. 3.ed. São Paulo, Companhia das Letras, 1994.

BRUCE-MITFORD, Miranda. O livro ilustrado dos signos e símbolos. Trad. José Vieira de Lima. Centralivros, 1996.

BRUNRL, P.; ICHOIS, C.; ROUSSEAU, A.M. Que é literatura comparada. Trad. Célia Berrettini. São Paulo, Perspectiva, 1995.

CALLOIS, Roger. O Homem e o sagrado. Trad. Geminiano Cascais Franco. Lisboa, Perspectivas do Homem/Edições 70, 1988.

CAMARGO, Luís. Ilustração do livro infantil. Belo Horizonte, Editora Lê, 1995.

CAMPBELL, Joseph. O herói de mil faces. São Paulo, Cultrix, 1997.

O poder do mito. Trad. Carlos Felipe Moisés. São Paulo, Associação Palas Athena, 1990.

CANDIDO, Antonio. Formação da literatura brasileira. 8.ed., Belo Horizonte, Itatiaia, 1997. v.1.

Literatura e sociedade. 9.ed., Rio de Janeiro, Ouro sobre Azul, 2006.

O estudo analítico do poema. 4.ed., São Paulo, Humanitas, 2004.

CANIATO, Benilde. Percursos pela África e por Macau. São Paulo, Ateliê Editorial, 2005.

CARVALHAL, Tânia Franco. O próprio e o alheio: ensaios de literatura comparada. São Leopoldo, RS, Unisinos, 2003.

(org.). Literatura comparada no mundo: questões e métodos. Porto Alegre, L\&PM/VITAE/AILC, 1997.

CASSIRER, Ernst. Ensaio sobre o homem. São Paulo, Martins Fontes, 1994.

CAVACAS, Fernanda. Mia Couto: acrediteísmos. Lisboa, Mar Além Edição de Publicações, 2001. 
Mia Couto: brincriação vocabular. Lisboa, Mar Além Edição de Publicações e Instituto Camões, 1999.

- Mia Couto: pensatempos e improvérbios. Lisboa, Mar Além Edição de Publicações, 2000.

CHAVES, Rita. Angola e Moçambique: experiência colonial e territórios literários. São Paulo, Ateliê Editorial, 2005.

; MACEDO, Tânia (org.). Marcas da diferença: as literaturas de língua portuguesa. São Paulo, Alameda, 2006.

CHEVALIER, Jean; GHEERBRANT, Allain. Dicionário de símbolos: mitos, sonhos, costumes, gestos, formas, figuras, cores, números. Trad. Vera da Costa e Silva et al. 10. ed., Rio de Janeiro, José Olympio, 1996.

CHIAMPI, Irlemar. O realismo maravilhoso. São Paulo, Perspectiva, 1980.

COELHO, Nelly Novaes. Literatura: arte, conhecimento e vida. São Paulo, Peirópolis, 2000.

- Literatura infantil: teoria, análise e didática. 6.ed. rev., São Paulo, Ática, 1993.

- O conto de fadas. 2.ed., São Paulo, Ática, 1991.

. Panorama histórico da literatura infantil e juvenil. 3.ed., São Paulo, Quíron, 1995.

COMTE, Auguste. Os Pensadores. 2.ed., São Paulo, Abril Cultural, 1983.

COUTO, Mia. A chuva pasmada. Lisboa, Editorial Caminho, 2004.

. Contos do nascer da terra. 6.ed., Lisboa, Editorial Caminho, 2006.

. A varanda do frangipani. 7.ed., Lisboa, Editorial Caminho, 2003.

. Estórias abensonhadas. 2.ed. Lisboa, Editorial Caminho, 1998.

. II. Danuta Wojciechowska. O gato e o escuro. 8.ed., Lisboa, Editorial Caminho, 1987.

. Mar me quer. II. João Nasi Pereira. 5.ed., Lisboa: Editorial Caminho, 2000.

. O último voo do flamingo. São Paulo, Companhia das Letras, 2005.

- Pensatempos: textos de opinião. 2.ed. Lisboa, Editorial Caminho, 2005.

- Raiz de orvalho e outros poemas. 3. ed., Lisboa, Editorial Caminho,1999.

- Terra sonâmbula. 8.ed., Lisboa, Editorial Caminho, 2004.

. "Vivemos a vertigem do caos". O Estado de São Paulo, 16 de junho de 2007.

. Vozes anoitecidas. 8.ed., Lisboa, Editorial Caminho, 1987. 
. Um rio chamado tempo, uma casa chamada terra. São Paulo, Companhia das Letras, 2003.

DURAND, Gilbert. As estruturas antropológicas do imaginário. Trad. Hélder Godinho. São Paulo, Martins Fontes, 1997.

- O imaginário: ensaio acerca das ciências e da filosofia da imagem. 2.ed., Rio de Janeiro, Difel, 2001.

DURKEHIM, E. As formas elementares da vida religiosa. São Paulo, Paulinas, 1989.

ELIADE, Mircea. Aspectos do mito. Trad. Pola Civelli. 4.ed., São Paulo, Perspectiva, 1994.

Fontes, 1996.

Imagens e símbolos. Trad. Sônia Cristina Tamer. São Paulo, Martins - Mefistófeles e o andrógino. São Paulo, Martins Fontes, 1999.

. Mito do eterno retorno. Trad. José Antônio Ceschin. São Paulo, Mercuryo, 1992.

- Mito e realidade. Trad. Pola Civelli. 4.ed., São Paulo, Perspectiva, 1994.

- O conhecimento sagrado de todas as eras. Trad. Luiz L. Gomes. São Paulo, Mercuryo, 1995.

- O sagrado e o profano: a essência das religiões. Trad. Rogério Fernandes. Lisboa, Edição Livros do Brasil.s.d.

. Tratado de história das religiões. São Paulo, Martins Fontes, 1993.

FANTINI, Marli. Guimarães Rosa: fronteiras, margens, passagens. São Paulo, Ateliê Editorial/Senac, 2003.

FISCHER, Ernst. A necessidade da arte. Trad. Leandro Konder. 9.ed., Rio de Janeiro, Guanabara Koogan, 2002.

GIRARD, René. A violência e o sagrado. Trad. Martha Conceição Gambini. 2.ed., São Paulo, Paz e Terra, 1990.

GÓES, Lúcia Pimentel. Introdução à literatura infantil / juvenil. 2.ed., São Paulo, Pioneira, 1991.

. Olhar de descoberta. São Paulo, Mercuryo, 1996.

JOHAN HUIZINGA, Johan. Homo ludens. São Paulo, Perspectiva, 1996.

JOLLES, André. Formas simples: legenda, saga, mito, adivinha, ditado, caso, memorável, conto, chiste. Trad. Álvaro Cabral. São Paulo, Cultrix, 1976.

JUNG, Carl. El hombre y sus símbolos. Barcelona, Luis de Caralt Editor, 1964. 
LEITE, Ana Mafalda. Literaturas africanas e formulações pós-coloniais. 2.ed., Maputo, Imprensa Universitária, Universidade Eduardo Mondlane, 2004.

MACHADO, Álvaro Manuel; PAGEUAX, Daniel-Henri. Da literatura comparada à teoria da literatura. Portugal, Edições 70, 1988.

MAFFESOLI, Michel. Notas sobre a pós-modernidade: o lugar faz o elo. Rio de Janeiro, Atlântica, 2004.

Record, 2001.

Sobre o nomadismo: vagabundagens pós-modernas. Rio de Janeiro,

MARGATO, Izabel; GOMES, Renato Cordeiro (org.). Literatura/política/cultura: 1994-2004. Belo Horizonte, UFMG, 2005.

MARTIN. Vima Lia (org.). Diálogos críticos: literatura e sociedade nos países de língua portuguesa. São Paulo, Arte e Ciência, 2005.

MARTINS, Nilce Sant'Anna. Introdução à estilística: a expressividade na língua portuguesa. 2.ed. São Paulo, T.A. Editor. 1997.

MARX, K. O capital: crítica da economia política. v.1. Trad. Reginaldo Sant'Anna. 11.ed., São Paulo: Bertrand Brasil-DIFEL, 1987.

MATOS, Gislayne Avelar. A palavra do contador de histórias: sua dimensão educativa na contemporaneidade. São Paulo, Martins Fontes, 2005.

MATUSSI, Gilberto. A construção da imagem de Moçambique em José Craveirinha, Mia Couto e Ungulani $\mathrm{Ba} K a$ Khosa. Moçambique, Livraria Universitária Universidade Eduardo Mondlane, 1998.

MAUSS, Marcel. Sociologia e antropologia. Trad. Paulo Neves. 2.ed., São Paulo: Cosac Naify, 2005.

MOISES, Massaud. A análise literária. 12.ed., São Paulo, Cultrix, 2005.

- Literatura: mundo e forma. São Paulo, Cultrix, Edusp, 1982.

MONTERO, Paula. Magia e pensamento mágico. São Paulo, Ática, 1986.

MORE, Thomas. Utopia. São Paulo, Martins Fontes, 1993.

MORIN, Edgar. Educar na era planetária: o pensamento complexo como método de aprendizagem no erro e na incerteza humana. São Paulo, Cortez, 2003.

Cortez, 2003.

Os sete saberes necessários à educação do futuro. 8.ed., São Paulo,

NITRINI, Sandra. Literatura Comparada: história, teoria e crítica. 2.ed., São Paulo, Edusp, 2000.

NOVAES, Adauto et al. O olhar. São Paulo, Companhia das Letras, 1988. 
OSTROWER, Fayga. Universos da arte. 9.ed., Rio de Janeiro, Campus, 1991.

OTTO, Rudolf. O sagrado. Trad. João Gama. Lisboa, Perspectivas do Homem/ Edições 70, 1992.

PADILHA, Laura Cavalcanti. Entre voz e letra: o lugar da ancestralidade na ficção angolana do século XX. Rio de Janeiro, EDUFF, 1995.

REVISTA DOSSIÊ. n.1. São Paulo, Centro de Estudos Portugueses, Universidade de São Paulo, 1998.

REVISTA VIA ATLÂNTICA. n.2. São Paulo, Departamento de Letras Clássicas e Vernáculas, Faculdade de Filosofia, Letras e Ciências Humanas, Universidade de São Paulo, 1999.

- n.3. São Paulo,Departamento de Letras Clássicas e Vernáculas, Faculdade de Filosofia, Letras e Ciências Humanas, Universidade de São Paulo, 1999.

. n.5. São Paulo, Departamento de Letras Clássicas e Vernáculas, Faculdade de Filosofia, Letras e Ciências Humanas, Universidade de São Paulo, 2002.

. n.8. São Paulo, Departamento de Letras Clássicas e Vernáculas, Faculdade de Filosofia, Letras e Ciências Humanas, Universidade de São Paulo, 2005.

. n.9. São Paulo, Departamento de Letras Clássicas e Vernáculas, Faculdade de Filosofia, Letras e Ciências Humanas, Universidade de São Paulo, 2006.

RILKE, Rainer Maria. Cartas a um jovem poeta. Trad. Paulo Rónai. Rio de Janeiro, Globo, 1995.

RIVIERE, Claude. Introdução à antropologia. Lisboa, Perspectiva/Edições 70, 2002.

ROSA, Guimarães. Grande sertão: veredas. Rio de Janeiro, Nova Fronteira, 1986.

. Primeiras estórias. 23.ed., Rio de Janeiro, Nova Fronteira, 1988.

SANTOS, Milton. Por uma outra globalização: do pensamento único à consciência universal. 7.ed., Rio de Janeiro, Record, 2001.

SARAMAGO, José. A jangada de pedra. São Paulo, Companhia das Letras, 1988.

TODOROV, Tzvetan. Introdução à literatura fantástica. 3.ed., São Paulo, Perspectiva, 2004.

TRESSIDER, Jack. O grande livro dos símbolos. Trad. Ricardo Inojosa. Rio de Janeiro, Ediouro, 2003.

UNESCO. América Latina em sua literatura. São Paulo, Perspectiva, 1979.

VERNANT, Jean-Pierre. Mito e pensamento entre os gregos. Rio de Janeiro, Paz e Terra, 1990. 
VON FRANZ, Marie Louise. O gato: um conto da redenção feminina. São Paulo, Paulus, 2003.

WELLEK, René; WARREN, Austin. Teoria da literatura. Trad. José Palla e Carmo. 5.ed., Lisboa, Europa - América, s.d.

ZUMTHOR, Paul. A letra e a voz: a "literatura" medieval. Trad. Amálio Pinheiro e Jerusa Pires Ferreira. São Paulo, Companhia das Letras, 1993. 


\section{ÍNDICE DE EXTRA-TEXTOS}

Capa - Montagem com as ilustrações de João Nasi Pereira, para Estórias Abensonhadas, de Mia Couto, e de Jorapimo, para Poemas concebidos sem pecados, de Manoel de Barros

Apresentação - Detalhe da capa da Dissertação de Mestrado

Desenho de Heloísa Fontana Baseio, aos 6 anos

Introdução - Ilustração 1 - Arte de Jorapimo para

Poemas concebidos sem pecados de Manoel de Barros (1987) . . . $\quad$. 20

Capítulo 1 - Ilustração 2 - Arte de João Nazi Pereira para

Mar me quer, de Mia Couto (2000) . . . . . . . . .

Capítulo 2 - Ilustração 3 - Arte de João Nazi Pereira para

Estórias Abensonhadas, de Mia Couto (2000)

Capítulo 3 - Ilustração 4 - Arte de Danuta Wojciechowska para

O gato e o escuro, de Mia Couto (2001)

Capítulo 4 - llustração 5 - Arte de Millôr Fernandes para

Retrato do artista quando coisa, de Manoel de Barros (2004)

- llustrações de Ana Raquel para

Poeminhas pescados numa fala de João, de Manoel de Barros (2001)

Figura 4.1

Figura 4.2

Figura 4.3

Figura 4.4

Figura 4.5

Figura 4.6

Figura 4.7

Capítulo 5 - Ilustração 6 - Arte de João Nasi Pereira para

Estória abensonhadas, de Mia Couto (1994)

- llustrações de Danuta Wojciechowska para

O gato e o Escuro, de Mia Couto (2001)

Figura 5.1

Figura 5.2

Figura 5.3

Figura 5.4

Capítulo 6 - Ilustração 7 - Arte de João Nasi Pereira para

Mar me que, de Mia Couto (2000) .

CONCLUSÃO - Ilustração 8 - Arte de João Nasi Pereira para

Mar me quer, de Mia Couto (2000)

IN-VOCAÇÃO PARA A ERRÂNCIA - Ilustração 9 - Arte de Jorapimo para

Poemas concebidos sem pecados, de Manoel de Barros (1987).

FINAL - Arte de Jorapimo para

Poemas concebidos sem pecados de Manoel de Barros (1987) 


\section{ANEXOS}

\section{CRONOLOGIA DAS OBRAS DE MANOEL DE BARROS}

1937 — Poemas concebidos sem pecado

1942 - Face imóvel

1956 - Poesias

1960 - Compêndio para uso dos pássaros

1966 - Gramática expositiva do chão

1974 - Matéria de poesia

1982 - Arranjos para assobio

1985 - Livro de pré-coisas (Ilustração da capa: Martha Barros)

1989 - O guardador das águas

1990 - Poesia quase toda

1991 - Concerto a céu aberto para solos de aves

1993 - O livro das ignorãças

1996 - Livro sobre nada (Ilustrações de Wega Nery)

1998 - Retrato do artista quando coisa (Ilustrações de Millôr Fernandes)

1999 - Exercícios de ser criança

1999 - Para encontrar azul eu uso pássaros: O Pantanal por Manoel de Barros

2000 - Ensaios fotográficos

2001 - O fazedor de amanhecer

2001 - Poeminhas pescados numa fala de João

2001 - Tratado geral das grandezas do ínfimo (Ilustrações de Martha Barros)

2003 - Memórias inventadas - A infância (Ilustrações de Martha Barros)

2003 - Cantigas para um passarinho à toa

2004 - Poemas rupestres (Ilustrações de Martha Barros)

2006 - Memórias inventadas: a segunda infância

\section{CRONOLOGIA DAS OBRAS DE MIA COUTO}

1983 - Raiz de orvalho

1986 - Vozes anoitecidas

1988 - Cronicando

1990 - Cada homem é uma raça

1992 — Terra sonâmbula

1994 - Estórias Abensonhadas

1996 - A Varanda do Frangipani

1997 - Contos do nascer da Terra

1998 - Mar me quer

1999 - Na berma de nenhuma estrada

1999 - Vinte e zinco

2000 - O último voo do flamingo

2001 - O gato e o escuro

2002 - Um rio chamado tempo, uma casa chamada Terra

2003 - O país do Queixa Andar

2003 - O fio das missangas

2004 - A chuva pasmadas

2005 - Pensatempos, textos de opinião

2006 - O outro pé da sereia 